ALESSANDRO DE OLIVEIRA SOARES

\title{
DO PROCESSO DE CASSAÇÃO DE MANDATO PARLAMENTAR POR QUEBRA DE DECORO
}

DISSERTAÇÃO DE MESTRADO

PROFESSORA ORIENTADORA

MONICA HERMAN SALEM CAGGIANO

UNIVERSIDADE DE SÃO PAULO

SÃO PAULO - 2011 


\section{ALESSANDRO DE OLIVEIRA SOARES}

DO PROCESSO DE CASSAÇÃO DE MANDATO PARLAMENTAR POR QUEBRA DE DECORO

Dissertação apresentada à Banca Examinadora da Faculdade de Direito da Universidade de São Paulo, como exigência parcial para a obtenção do título de Mestre em Direito do Estado sob a orientação da Professora Monica Herman Salem Caggiano.

\section{UNIVERSIDADE DE SÃO PAULO}

SÃO PAULO - 2011 
Banca examinadora 


\section{AGRADECIMENTOS}

Agradeço imensamente à professora Monica Hermann Salem Caggiano pela oportunidade de apresentar este trabalho, bem como pelo apoio e orientação dada ao longo de sua elaboração.

Ao meu amigo José Eduardo Cardozo a quem devo boa parte das análises que realizei.

À minha companheira de vida Caroline Rodrigues, que em todos os momentos esteve comigo nessa jornada intelectual.

Ao meu amigo e companheiro Ronaldo;

Ao meu pai Adão, à minha mãe Edinice e aos meus irmãos Lê, Li e Meire.

Aos meus amigos Igor e Eliane pelos comentários, correções e críticas.

A todos os meus amigos que dê uma forma ou de outra contribuíram e continuam a contribuir para minha formação humana. 


\section{RESUMO}

A presente dissertação tem por objeto de estudo o instituto da cassação de mandato por quebra de decoro, conforme previsto no art. 55, II, da Constituição da República de 1988, que determina que perca o mandato o deputado ou senador cujo procedimento for declarado incompatível com o decoro parlamentar. Trata-se de um estudo no qual analisamos diversos aspectos jurídicos relevantes do instituto, entre esses podemos destacar a definição mínima do que podemos entender por comportamento ofensivo ao decoro parlamentar, a natureza jurídica dos processos de cassação, os limites do exercício dessa competência pelas Casas do Congresso Nacional, as regras específicas previstas nos regimentos internos, bem como os limites do controle exercido pelo Poder Judiciário. Muitas das análises elaboradas são polêmicas e de difícil solução e envolvem temas candentes, não só do ponto de vista jurídico, mas também político, já que a cassação de mandato por quebra de decoro diz respeito a uma forma de perda antecipada do mandato representativo, implicando num fenômeno que resvala em todo o sistema democrático.

Palavras-chave: Direito constitucional. Direito político. Democracia. Responsabilidade política. Decoro parlamentar. Cassação de mandato. Representação política. 


\begin{abstract}
This dissertation is a study about the expel proceding a parliament member in case of offense to decorum according to art. 55 II of Republic Constitution of 1988, which states that lose the mandate the deputy or the senator who proceed in disorderly behavior with parliamentary decorum. We analyze various legal issues relevant to the institute, among these we can highlight the minimal definition of what we can call as an incompatible behavior with parliamentary decorum, the juridical nature of the legislative process of expulsion, limits for that jurisdiction by the Congress, the special rules of the Congress' internal regulations and the limits of control exercised by the Judiciary. Many elaborated analysis are controversial and difficult to solve, involving political and legal questions, since the expel by an incompatible behavior with parliamentary decorum is a way to lose beforehand the representative mandate, implying a phenomenon that echoes in all the democratic system.
\end{abstract}

Keywords: Constitutional Law. Political Law. Democracy. Political Responsibility. Parliamentary Decorum. Legislative Process of Expulsion. Political Representation. 


\section{LISTA DE ABREVIATURAS}

RICD - Regimento Interno da Câmara dos Deputados

RISF- Regimento Interno do Senado Federal

TCU - Tribunal de Contas da União 
SUMÁRIO

INTRODUÇÃO 10

PARTE I

MANDATO PARLAMENTAR E CASSAÇÃO POR QUEBRA DE DECORO: NOÇÕES GERAIS.

CAPÍTULO 1 - DO MANDATO PARLAMENTAR 28

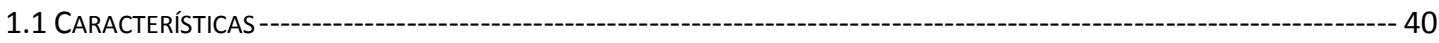

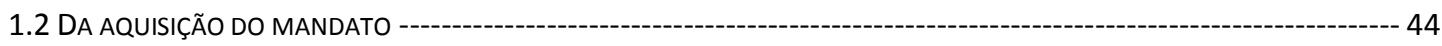

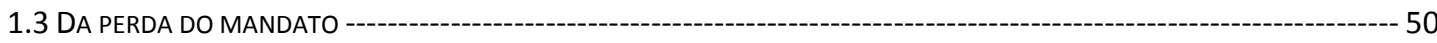

CAPÍTULO 2 - DO CONCEITO DE DECORO PARLAMENTAR: FONTES -

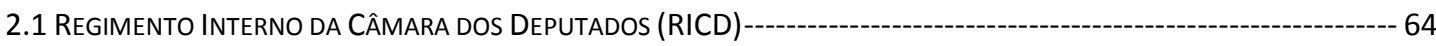

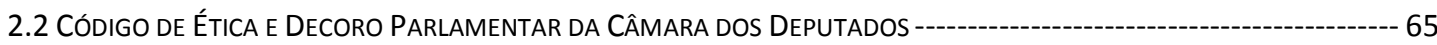

2.2.1 Dos atos atentatórios ao decoro em face do procedimento incompatível com o decoro----------- 70

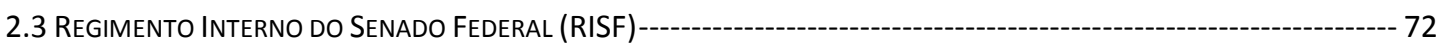

2.4 Código de ÉtICA E DeCoro ParlamentaR do SEnAdo FEDERAL -

CAPÍTULO 3 - HIPÓTESES DE CASSAÇÃO DE MANDATO POR QUEBRA DE DECORO NO CONSTITUCIONALISMO

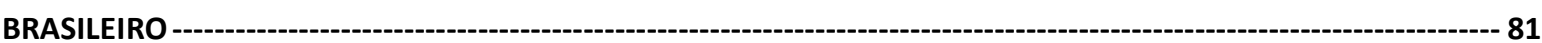

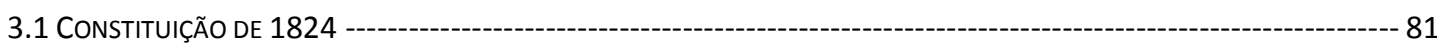

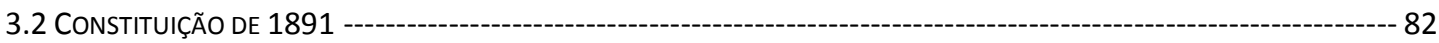

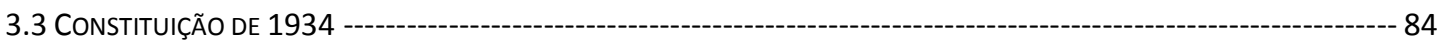

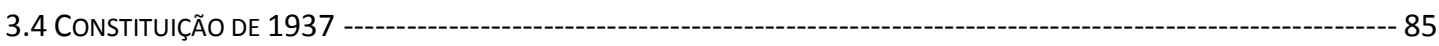

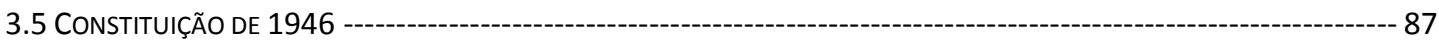

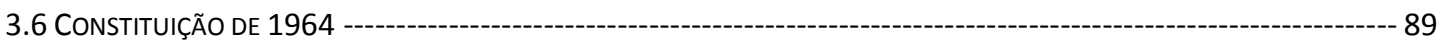

3.7 EMENDA CONSTITUCIONAL 01/69 --- 89

PARTE II

DO PROCESSO DE CASSAÇÃO DE MANDATO PARLAMENTAR POR QUEBRA DE DECORO

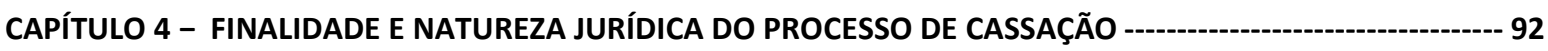

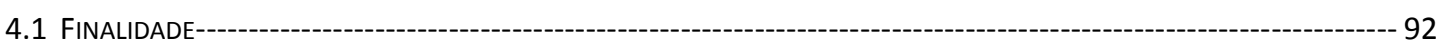

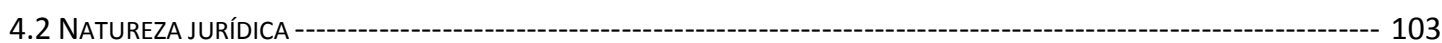

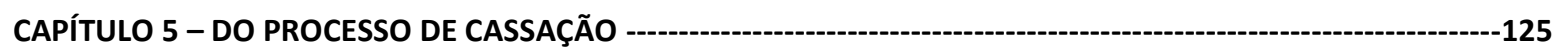

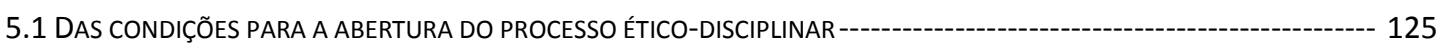

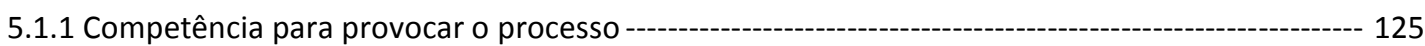

5.1.2 Sujeito passivo------------------------------------------------------------------------------------------ 126

5.1.2.1 Direito de renúncia ao mandato parlamentar e processo de cassação --------------------- 126

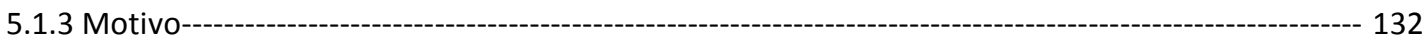

5.1.3.1 Princípio da unidade da legislatura e processo de cassação ----------------------------------- 132

5.1.3.2 Contemporaneidade da conduta com o exercício do mandato------------------------------- 138 
5.1.3.3 Da possibilidade de cassação de parlamentar licenciado----------------------------------------- 143

5.2 Do ConSELHo de ÉtICA E DECORO PARLAMENTAR --- 150

5.2.1 Do Conselho de Ética e Decoro Parlamentar da Câmara dos Deputados ------------------------- 151

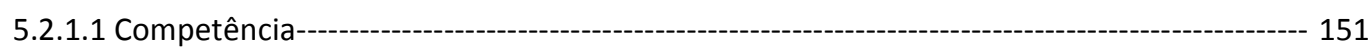

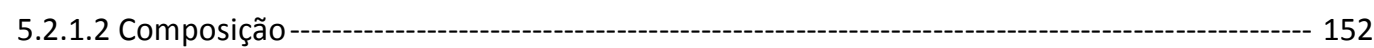

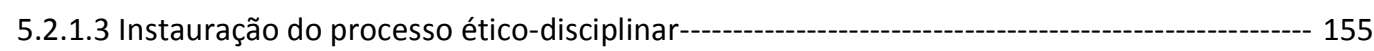

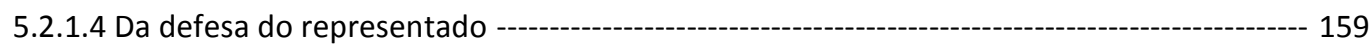

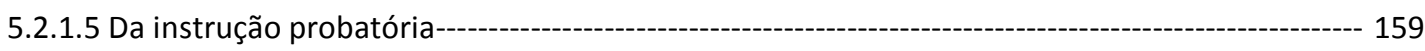

5.2.1.6 Da apreciação do parecer---------------------------------------------------------------------------- 162

5.2.2 Do Conselho de Ética e Decoro Parlamentar do Senado Federal ----------------------------------- 164

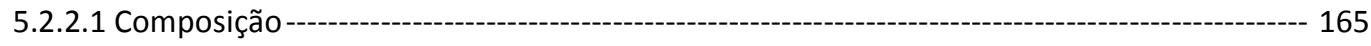

5.2.2.2 Da Instauração do processo a partir de representação ------------------------------------- 166

5.2.2.2.1 Do exame preliminar de admissibilidade da representação ----------------------- 167

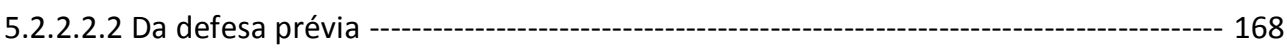

5.2.2.2.3 Da instauração do processo --- 169

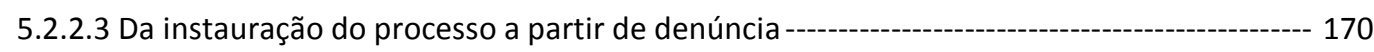

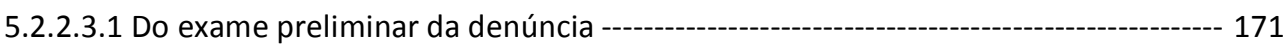

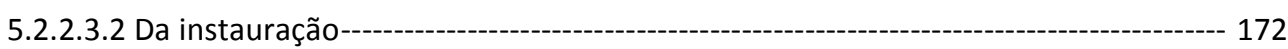

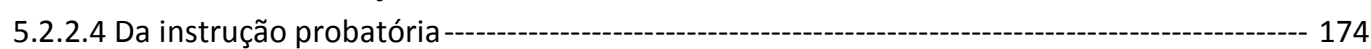

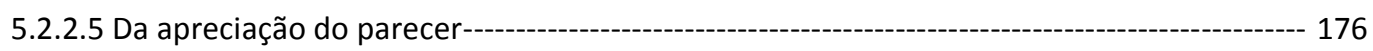

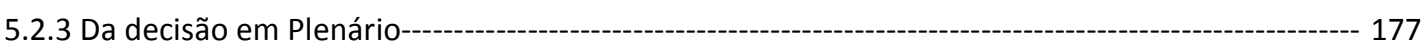

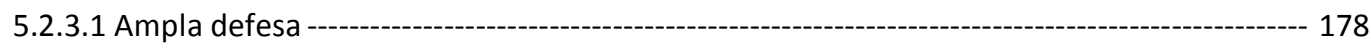

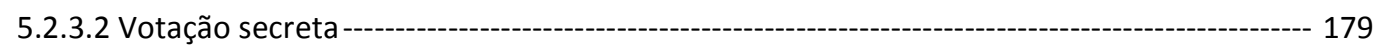

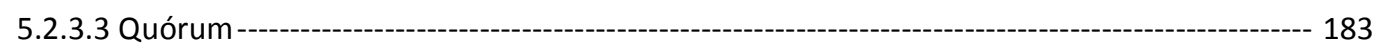

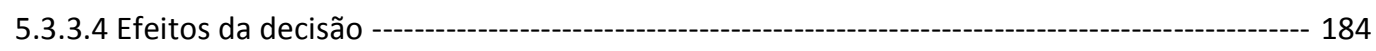

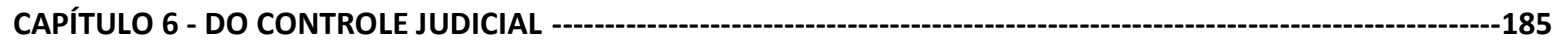

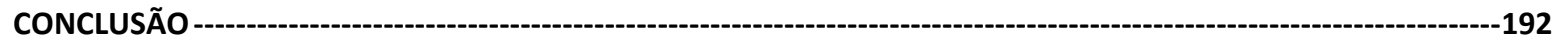

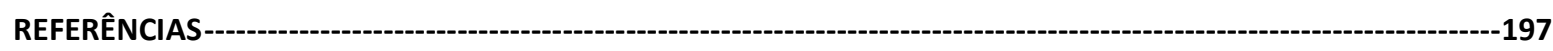




\section{INTRODUÇÃO}

A qualidade das instituições democráticas vincula-se diretamente à qualidade dos membros que as compõem, conclusão esta inevitável, já que as instituições não são seres em si com capacidade volitiva, mas têm sua atuação e funcionalidade determinada pelos agentes, seres humanos, os quais lhe dão vida concreta no campo estatal. Quando se fala sobre a qualidade dos agentes políticos ou públicos em geral, tal questão não se refere apenas a uma competência de caráter técnico, embora esse último aspecto seja de fundamental importância, mas trata-se também do preenchimento de requisitos de caráter moral demandados pelos destinatários do poder.

De fato, a luta pela moralidade do poder político constitui um retrato síntese do desenvolvimento do Estado moderno. Explique-se, sob determinados aspectos, que o desenvolvimento histórico do Estado moderno representou um caminhar da moralização do poder estatal: a passagem do Estado absolutista para o Estado Democrático de Direito, isto é, do exercício ilimitado e arbitrário do poder estatal fundado na lei pessoal do príncipe para o Estado democrático fundado em um sistema legal-racional amplo de impessoalidade (governam as leis, e não os homens). Embora essa imagem evolutiva histórica seja um pouco exagerada, já que não apreende os acontecimentos em sua particularidade, podemos compreender a queda dos regimes monárquicos absolutistas como uma não aceitação desse tipo de poder por parte dos súditos, de modo que a sua remodelação diante das necessidades históricas acabou por dar nascimento a uma nova forma de legitimação moral do poder (poder democrático liberal), mais condizente com a correlação de forças sociais vigentes. Esta, sem dúvida, é uma história focada no desenvolvimento das instituições estatais europeias a partir dos séculos XVII e XVIII, bem como diz respeito, fundamentalmente, às revoluções burguesas realizadas em Inglaterra e França.

Em que pese haver no campo político-filosófico discussão sobre a existência ou não de regras éticas para o mundo político, o fato é que, na vida cotidiana, os cidadãos requerem de seus governantes condutas moralmente aceitáveis e condizentes com os bens que têm a zelar. A realidade é, antes de tudo, impregnada de valores. O processo e a dinâmica do poder político são extremamente complexos. 
Mesmo Maquiavel, ao afirmar, a partir da experiência, que os príncipes que mais se destacaram pouco se preocuparam em honrar sua palavra, reconhece o quanto é louvável que um príncipe mantenha a palavra empenhada e viva com integridade, e não com astúcia. ${ }^{1} \mathrm{O}$ ilustre pensador sabia que sua constatação quanto aos fins e aos meios do poder político não coadunam com o discurso público. O poder estatal, enquanto campo de domínio político, não pode ter a aparência de uma negação daquilo que os súditos ou cidadãos esperam do poder instituído em seu caráter moral. Deve-se sempre buscar uma identidade mínima entre o polo do exercício do poder e o campo da sociedade. O poder público do Estado é um poder com prestígio, dele se espera algo que corresponda, de alguma forma, às expectativas dos destinatários do poder; por tal razão, lá só devem estar aqueles que estão moralmente à altura do prestígio institucional.

Então, temos que, de maneira geral, a moral dos agentes públicos é uma demanda concreta inequívoca do poder estatal e que diz respeito à perspectiva de sua própria manutenção como poder legítimo. Visando garantir a moralidade pública, nossa Constituição republicana de 1988 sedimenta, em seu art. 37, o princípio da moralidade como diretriz a ser observada por todas as esferas do poder do Estado. Significa não só que o agente público no exercício de sua função deve atuar de maneira ética, mas que na sua própria vida privada precisa igualmente se comportar de forma condizente com as funções públicas que exerce.

A Constituição, ao cindir os órgãos do poder estatal em três - Executivo, Legislativo e Judiciário (art. $2^{\circ}$ da Constituição Federal) - impõe uma reflexão jurídica própria quanto à moral aplicada a cada um desses órgãos superiores. O tema que será desenvolvido no presente estudo refere-se ao princípio da moralidade pública aplicado ao Poder Legislativo, especificamente no diz respeito ao decoro parlamentar, à sua violação e à possibilidade de

\footnotetext{
${ }^{1}$ A passagem está no Capítulo XVIII de O príncipe: "O quão louvável é que um príncipe honre a sua palavra e viva de uma forma íntegra, cada qual o compreenderá. Todavia, a experiência nos faz ver que, nestes nossos tempos, os príncipes que mais se destacaram pouco se preocuparam em honrar as suas promessas; que, além disso, eles souberam, com astúcia, ludibriar a opinião pública; e que, por fim, ainda lograram vantagens sobre aqueles que basearam as suas condutas na lealdade" (MAQUIAVEL, Nicolau. O príncipe. Tradução Antonio Caruccio-Caporale, Porto Alegre: L\&PM, 2007, p. 84). Semelhante percepção teve Weber, ao analisar o desenvolvimento do sistema político estadunidense, no qual viu um sistema dominado por corruptos. Uma das figuras corruptas identificadas por Weber era o boss, que, ao seu olhar, era um verdadeiro "empresário político capitalista" que investia em eleições visando tirar vantagens pessoais. Em uma conclusão seca, Weber reconhece: "Contudo, em razão mesmo da concorrência que se estabelece para ganhar o favor público, os bosses viram-se, algumas vezes, obrigados a resignar-se e a aceitar justamente os candidatos que se apresentavam como adversários da corrupção" (WEBER, Max. Ciência e política: duas vocações. Tradução de Leônidas Hegenberg e Octany Silveira Mota. São Paulo: Cultrix, 1983, p. 99).
} 
penalização do agente violador. Trata-se do estudo do instituto do processo de cassação de mandato por quebra de decoro ${ }^{2}$ parlamentar previsto no art. 55, II, da Constituição de 1988.

Antes de propriamente delinearmos o objeto a ser explorado e o caminho trilhado nas páginas que seguem, cabe tecer algumas considerações importantes. Ao colocar no centro de nosso estudo a moralidade pública vinculada ao Poder Legislativo e seus agentes, estamos inexoravelmente chamando a atenção para um tema de alta relevância e atualidade. Nesse sentido, uma constatação se faz necessária: o fato de que, se contemporaneamente é constante a discussão na literatura jurídica e política sobre a temática da crise do Estado, considerada em suas diversas dimensões, ${ }^{3}$ não é menos evidente que tal crise passe pelas questões da moralidade da conduta dos representantes políticos.

Nessa perspectiva, a questão do decoro parlamentar insere-se visivelmente no contexto da crise do Estado, o que impõe concluirmos também que a busca da superação dessa crise liga-se diretamente à construção de mecanismos de aperfeiçoamento e perfectibilidade do exercício do poder político. A crise política diz respeito, inclusive, a uma crise moral que tem por efeito básico o solapamento das instituições democráticas.

Por óbvio, as nuanças dos problemas ou da crise enfrentada particularmente pelo Poder Legislativo têm um caráter amplo e complexo; a esse respeito, muitos de seus críticos, embora imbuídos de um espírito excessivamente antiparlamentar, o constataram ao tentar enumerá-los, como vemos a seguir:

... el dominio de los partidos y su inadecuada política de personalidades, el "gobierno de aficionados", las permanentes crisis gubernamentales, la inutilidad y banalidad de los discursos parlamentarios, el nível, cada vez más bajo, de los Buenos modales parlamentarios, los destructivos métodos de obstrucción parlamentaria, el abuso de la inmunidad y privilegios parlamentarios por parte de una oposición radical que se burla del parlamentarismo mismo, la indigna práctica de las dietas y la escasa asistencia a las sesiones. ${ }^{4}$

${ }^{2}$ A Constituição, ao se referir ao decoro no art. 55, II, claramente adota o termo "procedimento incompatível com o decoro". Na determinação do tema de nosso estudo, preferimos a nomenclatura "quebra de decoro".

${ }^{3}$ Para elucidar o sentido dessa crise do Estado, podemos citar a seguinte passagem de autoria de Bobbio: "Por crise do Estado entende-se, da parte de escritores conservadores, crise do Estado democrático, que não consegue mais fazer frente às demandas provenientes da sociedade e por ele mesmo provocadas; da parte de escritores socialistas ou marxistas, crise do Estado capitalista, que não consegue mais dominar o poder dos grandes grupos de interesse em concorrência entre si” (BOBBIO, Norberto. Estado, governo, sociedade: para uma teoria geral da política. Rio de Janeiro: Paz e Terra. Tradução de Marco Aurélio Nogueira, 2010, p. 126).

4 “...o domínio dos partidos e sua inadequada política personalíssima, o "governo de interesseiros", as permanentes crises governamentais, a inutilidade e banalidade dos discursos parlamentares, o nível, cada vez 
Interessante observar que, nesse contexto de crise institucional, fala-se também em “crise da lei”, isto é, do próprio produto típico dos parlamentos. As leis atualmente teriam se expandido e multiplicado de tal forma e com tamanha velocidade a ponto de transformarem o mundo jurídico em uma babel instável e insegura, contradizendo a previsibilidade e a segurança que deveriam ser resultantes da aplicação do direito positivo. Como conclui Manoel Gonçalves Ferreira Filho: “A multidão de leis afoga o jurista, esmaga o advogado, estonteia o cidadão, desnorteia o juiz". 5

O efeito dessa inflação normativa seria a desvalorização do direito positivo, o que, ao extremo, levaria "à anulação de todo o sistema jurídico e, principalmente, de sua unidade dogmática". ${ }^{6}$ Em adendo, as leis teriam perdido suas características típicas de generalidade e abstração, contribuindo ainda mais para a imprevisibilidade e a insegurança na aplicação do direito. A época atual estaria marcada, assim, pela pulverização do direito legislado causada pela multiplicação das leis de caráter temporal e setorial. ${ }^{7}$ Não bastando esses problemas apontados pela doutrina, no âmbito dessa crise do Poder Legislativo, coloca-se também a própria inadequação dos procedimentos parlamentares, que teriam se tornado por demais burocráticos e lentos para um mundo complexo, que demanda cada vez mais uma atuação rápida e eficiente. ${ }^{8}$

Constata-se, então, que os problemas relacionados aos comportamentos éticos dos membros do Poder Legislativo correspondem a uma pequena parte do que se costuma chamar de crise do Estado. A análise, nesse ponto, revela a necessidade do enfrentamento de uma situação concreta e atual à qual a ninguém é dado desconhecer. Por tal razão, Giovanni Sartori

mais baixo, das boas maneiras parlamentares, os métodos destrutivos de obstrução parlamentar, o abuso de imunidades e privilégios parlamentares por parte de uma oposição radical que zomba do próprio parlamentarismo, a prática indigna de diárias e o precário auxílio às sessões. [tradução livre do autor] SCHMITT, Carl. Sobre el parlamentarismo. Madrid: Tecnos, 1990, p. 24-25.

${ }^{5}$ FERREIRA FILHO, Manoel Gonçalves. Do processo legislativo. São Paulo: Saraiva, 2002, p. 13.

${ }^{6}$ FARIA, José Eduardo. O direito na economia globalizada. São Paulo: Malheiros, 2002, p. 133.

${ }^{7}$ ZAGREBELSKY, Gustavo. El derecho dúctil. Ley, derechos, justicia. Madrid: Trotta, 2008, p. 37.

${ }^{8}$ Pertinente nesse sentido é a análise de Hamon, Troper e Burdeau: "Ocorre frequentemente nos Estados modernos que os parlamentares enfrentem algumas dificuldades na garantia da função legislativa. Isso se deve a múltiplos fatores, à crescente tecnicidade dos projetos, à demora e à burocracia excessiva dos processos, quando se faz necessário agir rapidamente, às reticências dos parlamentares em adotar medidas úteis, mas impopulares, às divisões políticas e à ausência de maioria, que tornam cada decisão o resultado de compromissos laboriosamente negociados" (HAMON, Francis; TROPER, Michel; BURDEAU, Georges. Direito constitucional. Barueri: Manole, 2005, p. 127). Sobre a questão, ver também: CARDOZO, José Eduardo Martins. A crise do legislativo. São Paulo: Revista de Estudos Avançados da Universidade de São Paulo, n. 67, p. 82-83, 2009. 
afirma que: “... las democracias deben quitarse la suciedad, y que la "limpeza de la política” es la principal prioridad de nuestra época". 9

Diante dessa crise moral do Poder Legislativo e da própria política, é possível, dentre muitas possibilidades, guiarmo-nos por dois caminhos opostos: ou a instituição parlamentar com seu modelo de representação democrática - pode ser reparada com o intuito de cumprir com as finalidades para qual foi criada, ou estamos diante do fato de que a instituição é completamente inadequada, sendo necessário extingui-la com os políticos. Nessas hipóteses, ou temos a destituição do lugar institucional do Parlamento enquanto ambiente legítimo (lócus) para a dominação política (hipótese extrema), ou estamos diante do desafio da perfectibilidade da política de criar instrumentos capazes de defender a integridade da instituição parlamentar.

Como não pode deixar de ser, a questão nos remete ao próprio diagnóstico que se faz da crise vivenciada pelos Parlamentos. O pensamento de Giovanni Sartori de que um dos maiores desafios atuais das democracias constitucionais é a "limpeza da política" consubstancia uma avaliação de que a política democrática e suas respectivas instituições podem ser salvas e o devem ser. Nessa linha, é preciso saber separar instituições e indivíduos, ou melhor, para usar aqui a terminologia de Maurice Duverger, é necessário compreender a instituição como uma função desencarnada, ${ }^{10}$ inconfundível com o provisório representante político que se ocupa de seu exercício; por isso, é sempre possível aperfeiçoar os mecanismos de controle institucional de modo a garantir o exercício legítimo da função parlamentar.

A interpretação extrema que leva à descrença no Parlamento e à desilusão completa com a sua política pode ser encontrada no âmbito da literatura jurídica e política, comumente nos grandes períodos de crise, em que aparece com mais força e sem grandes disfarces discursivos. Uma das leituras mais atrevidas e simbólicas nesse sentido foi realizada por Schmitt durante a época de crise política, social e econômica na República de Weimar, em que comparou a política parlamentar a uma matilha de cães famintos devorando os bens públicos em nome dos interesses particulares, no qual nem o mais bem-intencionado representante parlamentar poderia fugir à tentação da política degenerada dos Parlamentos: “... llegando a

\footnotetext{
9 “...as democracias devem livrar-se da sujeira, a "limpeza da política” é a principal prioridade de nosso tempo." [tradução livre do autor]

SARTORI, Giovanni. Ingeniería constitucional comparada. México: Fondo de Cultura Económica, 2005 , p. 163.

${ }^{10}$ DUVERGER, Maurice. Métodos de las ciencias sociales. Barcelona: Ariel, 1980, p. 520.
} 
encontrarse, en fin de cuentas, como aquel famoso perro de la fábula de Lafontaine, que con los mejores propósitos guarda el asado de su señor, pero cuando otros perros caen sobre él, se aviene a participar en el banquete". 11

Em geral, esse tipo de leitura negativista da política é feita quando, de boa-fé ou imbuído de uma intenção oportunista, se leva a sério demais certo ideal de política, quando a convicção nesse ideal político é posta à prova diante da realidade a partir de um "tudo ou nada", em um comportamento próximo de uma ética da convicção weberiana. ${ }^{12}$ No confronto entre uma democracia ideal, na qual a volonté générale deve ser encontrada pela atuação de um legislador atento aos melhores princípios de justiça, ${ }^{13}$ com as rotinas cotidianas do exercício do poder nos Estados constitucionais contemporâneos, o resultado só pode ser a negação completa da política como tal, isto é, da política do Estado democrático representativo. Concluindo que a instituição parlamentar não está à altura desses ideais políticos, resta a busca do exercício do poder político por outros meios. A luta política institucional tende, então, a se dar em outros campos. O efeito aqui seria igual ao da perda de consenso democrático e da fé nas instituições. Esse fenômeno se aproxima da abstenção ativa de que trata Pierre Bourdieu, no qual a impotência perante os aparelhos políticos gera "o

11 "chegando a ser, no fim das contas, como aquele famoso cachorro da fábula de Lafontaine, que com as melhores intenções guarda a carne assada de seu mestre, mas quando outros cães caem sobre ela, concorda em participar do banquete." [tradução livre do autor] SCHMITT, Carl. La defensa de la constitución. Barcelona: Editorial Labor, 1931, p. 112.

${ }^{12}$ Para Weber, toda atividade pode ser orientada por dois tipos de ética: a ética da convicção e a ética da responsabilidade. A atitude que opera na base de uma ética da convicção leva em consideração apenas o cumprimento do dever estabelecido, não se importando quanto aos resultados, mesmo que estes sejam negativos do ponto de vista concreto. Isso ocorre porque não se tem responsabilidade pelas condutas - se algo deu errado ou se o resultado foi então indesejado, é porque a força externa que determinou a obrigação assim desejou. Não assume a responsabilidade da conduta, apenas age com a convicção de que está fazendo correto. O exemplo de Weber é clássico: "O cristão cumpre seu dever e, quanto aos resultados da ação, confia em Deus - e a atitude de quem se orienta pela ética da responsabilidade, que diz: Devemos responder pelas previsíveis consequências de nossos atos" (WEBER, Max. Ciência e política: duas vocações. São Paulo: Cultrix, 1983, p. 113).

${ }^{13}$ Rawls, em sua obra Uma teoria da justiça, traz o exemplo desse tipo de idealização da atuação política parlamentar: "De maneira semelhante, leis e políticas justas são aquelas que seriam instituídas no estágio legislativo por legisladores racionais, dentro das limitações impostas por uma constituição justa e que se esforçam conscientemente por seguir os princípios de justiça como seu critério. Quando criticamos leis e políticas, tentamos mostrar que elas não seriam escolhidas nesse processo ideal. [...] No procedimento ideal, a decisão tomada não é um compromisso, uma negociação entre adversários que tentam promover seus objetivos. A discussão legislativa deve ser concebida não como uma competição de interesses, mas como a tentativa de descobrir a melhor política tal como definida pelos princípios de justiça" (RAWLS, Jhon. Uma teoria da justiça. São Paulo: Martins Fontes, 2008, p. 445). Sobre esse ponto, ver também: MILLS, C. Wrigh. A sociedade de massas. In: FORACCHI, Marialice Mencarini; MARTINS, José de Souza (Org.). Sociologia e sociedade: leituras de introdução à sociologia. Rio de Janeiro: Livros Técnicos e Científicos, 1977, p. 308 e SCHMITT, Carl. Teoría de la constitución. Madrid: Alianza Universidad, 2009, p. 297. 
apolitismo, que assume por vezes a forma de um antiparlamentarismo e que pode ser desviado para todas as formas de bonapartismo, de boulangismo ou de gaulismo". ${ }^{14}$

Em vez de adotarmos essa leitura de negação completa e radical da política, engendradora de uma "política da antipolítica", para usar aqui termos de Giovanni Sartori, ${ }^{15}$ é interessante constatar que, precisamente desse paradoxo entre o ideal político e a realidade política, se dá a construção "de mecanismos institucionais que configuram o que hoje conhecemos como democracia liberal: a regra da maioria, a separação de poderes e independência dos poderes, o mandato representativo limitado, as eleições livres e regulares, e outras". ${ }^{16}$ Trata-se, com efeito, não de levar a termo uma idealização ou aceitar certa forma de real politik, no sentido da política como ela é, mas na margem dessa oposição realizar o caminho da política em direção à construção de uma realidade aproximada das construções ideais. Obviamente, por esse caminho pode se dar também a desconstrução desses ideais, mas não é oportuno de alongarmos as análises nesse sentido.

Como já se supõe, a presente pesquisa remete-nos à questão de como tornar a democracia representativa possível dentro das condições vigentes no âmbito do Estado moderno - diga-se, no âmbito do Estado brasileiro. Impõe, assim, considerar a política democrática pela sua feição positiva, o que é pertinente ao próprio mecanismo da cassação de mandato por quebra de decoro, pois a depuração política realizada pela aplicação da sanção ao parlamentar faltoso tem o significado de que há um valor a ser defendido no plano institucional. A emergência da "limpeza da política" é, com efeito, uma demanda de caráter público, é a própria imagem da política no cotidiano dos escândalos e de sua divulgação pelos meios de comunicação, que têm reforçado continuamente no imaginário grande público uma imagem detestável da política e dos políticos, imagem similar à matilha de cães de Schmitt. Com isso, queremos dizer que o problema não começa com os teóricos negativistas, mas, sim, quando suas ideias e pensamentos passam a ser a visão ampla da política por parte da opinião pública, abrindo espaços para quebras institucionais.

Nesse contexto de crise moral do Parlamento, José Eduardo Martins Cardozo alerta precisamente para essa questão:

\footnotetext{
${ }^{14}$ BOURDIEU, Pierre. O poder simbólico. Rio de Janeiro: Bertrand Russel, 1998, p. 169.

${ }^{15}$ SARTORI, Giovanni. Ingeniería constitucional comparada. México: Fondo de Cultura Económica, 2005, p. 161.

${ }^{16}$ RUA, Maria das Graças. Desafios da administração pública brasileira: governança, autonomia, neutralidade. Brasília: Revista do Serviço Público, ano 48, n. 3, set./dez. 1997, p. 136.
} 


\begin{abstract}
Quando caem as ditaduras, porém, e, como a fênix, renasce a vida democrática, muito tempo não se exigirá para que o Parlamento passe a ser visto como instituição improdutiva, lenta, parasitária, ocupada por "políticos” inúteis, ineptos ou hipócritas, verdadeiros sanguessugas que vivem do erário, locupletando-se indevidamente ou fartando-se de privilégios e "mordomias" que conseguem obter no exercício do seu pomposo e "inútil” poder. Para que servem "Suas Exas", afinal? É a pergunta que corre, implícita ou explicitamente, as ruas, as casas, os bares, os salões de barbeiros e cabeleireiras quando os ares são de democracia. ${ }^{17}$
\end{abstract}

Não é o caso de discutirmos todos os problemas que enfrentam os Parlamentos contemporaneamente, mas, antes, de salientar aqueles de ordem moral da conduta de seus membros. O poder político busca, assim, mecanismos de defesa de sua dignidade institucional enquanto elemento da construção de sua legitimação, que, no fundo, contribui para a legitimidade de todo o sistema jurídico constitucional e infraconstitucional.

É de se destacar a ideia de que a crise que atinge os Parlamentos modernos configura também uma crise ética, a qual remonta ao comportamento dos seus membros e reflete apenas uma forma genérica de se abordar o assunto. Tal fato não é oportuno para a análise científica que propomos, pois o que temos, em realidade, no mundo concreto são "crises" que cada Estado democrático constitucional tem vivenciado de maneira particular. Se, por um lado, podemos dizer, acompanhando Abreu Sodré, que o fenômeno da crise dos Parlamentos "não abarca esta ou aquela instituição, neste ou naquele país, mas a própria instituição como tal", ${ }^{18}$ por outro devemos complementar que a "instituição como tal" só existe de acordo com o que tenha sido efetivado em cada Estado, que tem sua conformidade determinada pelo respectivo texto constitucional que lhe rege. Importa ressaltar esse aspecto para que um diagnóstico particular redunde em soluções específicas, pertinentes aos objetivos almejados.

Toda essa emergência ética política de cunho geral ganha determinações próprias na constatação de que grande parte das análises da situação ético-pública no Brasil parte quase inevitavelmente da observação histórica de que a distinção entre uma esfera pública e outra privada sempre representou um dos maiores desafios ao estabelecimento de um Estado constitucional democrático no País. Parece ser realmente este um traço característico de nosso desenvolvimento: a confusão entre o público e o privado. Formado na base do autoritarismo

${ }^{17}$ CARDOZO, José Eduardo Martins. A crise do legislativo, cit., p. 81.

${ }^{18}$ SODRÉ, Roberto Costa de Abreu. O parlamento e o Estado moderno. Brasília: IPEAC, 1973, p. 05. 
daqueles que Raymundo Faoro chamou de os "donos do poder", o Estado brasileiro foi, desde os primórdios de sua instauração histórica, tratado como um domínio fechado de alguns: o Estamento. ${ }^{19}$ Configurou-se, assim, como um Estado "patrimonial", no qual a gestão do público aparece imediatamente como um interesse privado; o exercício da função pública e os cargos, atividades e dinheiro a ele relacionado, aparecem aos olhos do funcionário como um direito pessoal de que pode dispor conforme determine o interesse e as necessidades. ${ }^{20}$ Nesse modelo, as relações estatais fundam-se no "personalismo", dando ensejo a fenômenos como o favoritismo, o nepotismo e o clientelismo. Não se trata, logicamente, de tomar essas características de forma caricata e espiritualista como modelo psicológico inato do povo; pelo contrário, elas estão vinculadas às condições materiais com que tivemos que engendrar a nação.

Sem dúvida, a herança da indistinção entre o público e o privado tem influído sobremaneira na evolução histórica de nossas instituições até os dias atuais, atingindo de forma peculiar o Poder Legislativo. No entanto, devemos asseverar que o espectro dos mortos não explica por si só a situação presente, amálgama de muitas determinantes. Destarte, é preciso ter muito cuidado para que um diagnóstico da situação atual não se perca em um historicismo descontextualizado.

Nos últimos anos, com a publicidade dada pelos holofotes da grande imprensa, temos observado como boa parte de nossos parlamentares tem atuado com pouco apreço a qualquer moral pública, em desrespeito constante ao povo. Observa Manoel Gonçalves Ferreira Filho que "não passa um dia no Brasil contemporâneo sem que seja formulada uma acusação de

\footnotetext{
${ }^{19}$ Diz Faoro sobre essa camada dominante: "O ESTAMENTO, quadro administrativo e estado-maior de domínio, configura o governo de uma minoria. Poucos dirigem, controlam e infundem seus padrões de conduta a muitos. $\mathrm{O}$ grupo dirigente não exerce o poder em nome da maioria, mediante delegação ou inspirado pela confiança que do povo, como entidade global, se irradia. É a própria soberania que se enquista, impenetrável e superior, uma camada restrita, ignorante do dogma do predomínio da maioria (FAORO, Raymundo. Os donos do poder. São Paulo: Globo, 2008, p. 107-108). Sobre o desenvolvimento desse grupo social durante o Ancien Régime, Enterría afirma: "era en absoluto en el Antigo Régimen, donde no sólo el Rey, sino también los nobles ostentaban un oficio público como una titularidad subjetiva patrimonial, que se hereda, se vendia, se compraba" (ENTERRÍA, Eduardo Garcia. El principio de "la responsabilidad de los poderes públicos" según el art. 9.3 de la Constittución y la responsabilidad patrimonial del estado legislador. Revista de Derecho Constitucional, año 23, n. 67, enero/abr. 2003, p. 30).

${ }^{20}$ HOLANDA, Sérgio Buarque de. Raízes do Brasil. São Paulo: Companhia das Letras, 1995, p. 146.
} 
corrupção. Todos os dias jornais ou revistas, o rádio ou a televisão, as tribunas parlamentares" ${ }^{21}$ apontam casos de corrupção. ${ }^{22}$

Se fizermos um confronto entre a história constitucional do País e as situações de escândalos de ordem moral envolvendo agentes públicos, notadamente os representantes políticos, não precisaremos de grande esforço para concluir que, sob a vigência da Constituição republicana de 1988, teríamos adentrado em um verdadeiro inferno da imoralidade na política. ${ }^{23}$ Derradeiro seria seguir Giovanni Sartori em sua assertiva de que a limpeza na política é a prioridade na agenda dos Estados constitucionais contemporâneos. Democracia e imoralidade, nesse caso, refletiriam, pelo menos aparentemente, faces da mesma moeda. Aliás, foi Alexis de Tocqueville que concluiu que, sob o regime democrático, as práticas desonestas e a corrupção dos agentes políticos tendem a se expandir, pois os que chegam casualmente ao poder têm em si algo de grosseiro e vulgar, contagioso para a multidão. Sua sentença era:

Lo que hay que temer, por outra parte, no es tanto el conocimiento de la inmoralidad de los grandes sino de la inmoralidad que conduce a la grandeza. En la democracia, los ciudadanos corrientes ven a un hombre que sale de sus filas y que llega em poços años a la riqueza y al poder; ese espectáculo excita su sorpresa y su envidia; tratan de averiguar cómo el que ayer apenas era su igual está ahora investido del derecho de dirigirlos. Atribuir su elevación a su talento o a sus virtudes es incómodo, porque es confesarse que ellos mismos son menos

${ }^{21}$ FERREIRA FILHO, Manoel Gonçalves. A corrupção como fenômeno social e político. Rio de Janeiro: Revista de Direito Administrativo, 1991, p. 01.

${ }^{22}$ É importante alertar que os males éticos que perturbam o ambiente institucional democrático no Brasil têm causas de extrema complexidade, não podendo ser explicado somente por alguns elementos de nossa herança histórica. Deve-se somar a este fator, por exemplo, o próprio sistema político que, em larga medida, incentivaria ocorrência desses fenômenos. José Eduardo Martins Cardozo entende que: “... devemos ressaltar que esse sistema eleitoral gera, em larga medida, a corrupção estrutural que temos em nosso país. As campanhas para o Parlamento, na medida em que feitas individualmente, exigem que cada candidato corra atrás dos recursos financeiros que as custeiam. Naturalmente esses recursos são decisivos para a eleição. Quanto mais dinheiro tiver um candidato, maior a possibilidade de sair vitorioso nesse universo pulverizado de competidores. [...] Fazer doações eleitorais em troca de vantagens ou de acumpliciamento futuro é uma realidade na nossa vida política. Esse sistema incentivador da corrupção propicia escândalos e, em consequência, o desgaste da imagem do Parlamento" (CARDOZO, José Eduardo Martins. A crise do legislativo, cit., p. 86). Ver também ROCHA, Cármen Lúcia Antunes. Princípios constitucionais da administração pública. Belo Horizonte: Del Rey, 1994, p. 203.

${ }^{23}$ Nesse sentido, assinala Cármen Lúcia "Talvez a década de 90 tenha projetado a preocupação com a moralidade pública a níveis antes não vistos neste século ou mesmo em qualquer outro. É difícil verificar-se a causa para que esta última década do século e do milênio, que vivemos, presencie este questionamento sobre os padrões morais a serem observados pelas pessoas políticas e pelos seus agentes (ROCHA, Cármen Lúcia Antunes. Princípios constitucionais da administração pública, cit., p. 203). 
virtuosos y menos hábiles. Hacen, pues, consistir la principal causa del ascenso en algunso de sus vícios, y a menudo tienen razón al hacerlo. Se opera así no sé qué odiosa mezcla entre ideas de bajeza y de poder, de intriga y êxito, de utilidad y deshonor. ${ }^{24}$

Acertadamente percebia o ilustre autor que, com a rotatividade do poder demandada pelas regras do jogo do regime democrático liberal, os que exerciam o poder político se colocavam agora em evidência aos olhos públicos, não se cobrindo mais com o véu dos modos aristocráticos. Essa percepção que vincula democracia e imoralidade traz à tona uma realidade inegável: a desonestidade e a conduta imoral estão em evidência e configuram um dos pontos cruciais da crise vivenciada nas democracias constitucionais contemporâneas. Todavia, essa primeira percepção é apenas uma aproximação vulgar e apologética em relação ao fenômeno, que requer muito mais cuidado e rigor científico para sua abordagem. Não é o propósito aqui tratar dessa questão, o que nos desviaria de nosso caminho analítico. Contudo, impõe-se que façamos alguns apontamentos, dispostos a seguir. Primeiro, é verdade que nas democracias constitucionais há uma tendência maior à ocorrência de escândalos morais envolvendo agentes públicos, especificamente representantes políticos. Se compararmos com os regimes autoritários, isso fica evidente. Mas tal situação se deve ao fato de que nos regimes autoritários há restrição à liberdade de informação e comunicação midiática, ${ }^{25}$ bem como de crítica. Sucede que a opinião pública não tem acesso contínuo e amplo sobre os problemas enfrentados no âmbito estatal, além dos controles institucionais serem fracos, senão

24 “O que há para temer, de outro lado, não é tanto o conhecimento da imoralidade dos grandes e sim a imoralidade que conduz à grandeza. Na democracia, os cidadãos comuns vêem um homem que sai de suas fileiras para chegar em poucos anos à riqueza e ao poder; esse espetáculo atiça-lhes a admiração e a inveja; procuram descobrir como aquele que ontem era apenas seu igual está agora investido do direito de dirigi-los. Atribuir sua ascensão a seu talento ou a suas virtudes é incomodo, porque seria confessar que eles mesmos são menos virtuosos e menos hábeis. Fazem, portanto, com que a principal causa da ascensão seja algum de seus vícios, e muitas vezes têm razão em fazê-lo. Opera-se assim não sei que odiosa mistura entre idéias de baixeza e poder, de intriga e sucesso, de utilidade e desonra." [tradução livre do autor] TOCQUEVILLE, Alexis. La democracia en América. México: Fondo de Cultura Económica, 2002, p. 233.

${ }^{25}$ Sobre a liberdade de mídia nos regimes democráticos diz Thompson: "Um terceiro fator que torna a democracia liberal propensa a escândalo é a relativa autonomia da imprensa. Emprego a expressão relativa autonomia propositadamente: nas sociedades democráticas liberais, as instituições da mídia não são inteiramente independentes do exercício do poder político. As instituições da mídia geralmente operam dentro de um referencial regulador estabelecido pelo Estado; além do mais, elas podem estar sujeitas a várias formas de pressão - tanto diretas, através de arranjos para consecução de fundos ou censura aberta, como indiretas - quando interferem em sua atividade. Apesar disso, comparados com a situação das instituições da mídia em estados autoritários ou de partido único, os meios de comunicação nas sociedades liberais possuem relativamente ampla liberdade de ação política (THOMPSON, John B. O escândalo político: poder e visibilidade na era da mídia. Petrópolis: Vozes, 2002, p. 129). 
inexistentes. Tudo ocorre às escuras, sem publicidade, sem oposição e sem crítica possível. Em síntese: o poder estatal não é uma "porta aberta" como nos regimes constitucionais pluralistas ocidentais, "nos quais os partidos políticos produzem e exercem sua atividade livremente, e a escolha dos governantes depende do resultado de eleições competitivas". ${ }^{26}$

Em um mundo resguardado da investigação pública haverá pouca possibilidade de ocorrência de escândalos políticos, pois os atos imorais e corruptos não sobem à superfície. Nesse sentido, não se pode fazer um comparativo sobre um quantum de imoralidade entre uma situação autoritária e uma democrática liberal sem tomar conhecimento dessas particularidades qualitativas.

O segundo ponto a ser observado é a circunstância de que o escândalo político, como uma característica marcante das sociedades contemporâneas ocidentais na qual impera a ordem democrática liberal, se dá por muitas causas, por exemplo: a crescente visibilidade dos líderes políticos, o aumento da regulamentação legal da vida política; a mudança nas tecnologias de comunicação e de vigilância; a mudança da cultura política causada pela falta de diferenciação ideológico-programática dos competidores pelo poder, o que remete a discussão da opinião pública para o campo da moral (politização da moral); ${ }^{27}$ a mudança na cultura jornalística, que acaba por dar ênfase às reportagens de cunho investigativo e de denúncia na perspectiva de pôr a nu a face subterrânea do poder. ${ }^{28}$

${ }^{26}$ HAMON, Francis; TROPER, Michel; BURDEAU, Georges. Direito constitucional, cit., p. 152

${ }^{27}$ Com respeito a esse específico fenômeno são elucidativas as palavras de Manoel Gonçalves Ferreira Filho: "Essa cristalização das maiorias eleitorais seria compreensível se os seus programas verdadeiramente exprimissem um projeto coerente de medidas ajustadas a uma conjuntura, de modo que do confronto de todos os programas resultasse uma escolha consciente do eleitorado sobre o destino da Nação. Não é isso, porém, o que se dá. Os programas partidários são, via de regra, abstratos e vagos, procurando magnetizar os eleitores com palavras mágicas, sem dizer ao certo nada de preciso, a ponto de, no fundo, muito se parecerem entre si" (Do processo legislativo, cit., p. 93).

${ }^{28}$ THOMPSON, John B. O escândalo político, cit., p. 142. Ao analisar a mesma problemática nos Estados Unidos, em que há uma interpretação geral na população de que os políticos contemporâneos são infinitamente mais imorais e corruptos do que os do passado, Denis F. Thompson pode chegar à seguinte conclusão: "If the character of members is not worse, and indeed may be better, why has the number of ethics case increased so dramatically? Two causes are probably most significant. First, violations of ethics rules are now more likely to be discovered and investigated. Congress itself is more open to public scrutiny than ever before and so are the personal and political lives of its members. The press is more vigilant, more eager to expose corruption wherever it can be found (and some would say, even where is cannot). More charges are brought against members. [...] A second cause effects the kinds of cases as much as the number. There are more offenders because there are more offenses. [...] There are more rules than there used to be, and more rules than in any other political system" (THOMPSON, Dennis F. Ethics in congress: from individual to institutional corruption. Washington: The Brookings Institution, 1995, p. 03). 
O terceiro e último aspecto que convém lembrar diz respeito a esse processo repetitivo de escândalos e denúncias de cunho moral ao qual foi submetido o Estado brasileiro durante a década de 1990, o qual veio amparado por uma solução política emitida pelo modelo (neo)liberalizante que dominou o ambiente à época, ou seja, a crise moral do Estado foi inserida em um discurso político que tinha interesse na constatação da crise moral, o que faz com que a análise da questão se coloque de forma mais complexa ainda para o analista. ${ }^{29}$

Independentemente de onde essa discussão sobre os vínculos entre imoralidade pública e democracia possa nos levar, devemos ressaltar que problemas de ordem ética no espaço público dizem respeito a sujeitos que, pelas relações que estabelecem na vida mundana, estão aptos a ofender princípios públicos de aceitação geral. ${ }^{30}$ Não se trata, pois, de encontrar o indivíduo perfeito para o exercício da função pública, mas, dentro das possibilidades, elaborar arranjos institucionais na estrutura do ordenamento jurídico que tendam a coibir os desvios pessoais. A utilidade de nosso estudo baseia-se nessa assertiva, ao considerar os representantes políticos parlamentares como seres falíveis no trato com os interesses públicos. Desse caráter negativo deve-se buscar o positivo das instituições. Conforme disse Karl Loewenstein: "El poder lleva en si mismo un estigma, y sólo los santos entre los detentadores del poder - y dónde se pueden encontrar - serían capaces de resistir a la tentación de abusar del poder". ${ }^{31}$

Diante de tal constatação, devemos observar que as conjunturas que revelam problemas nos meandros da conduta dos agentes políticos têm dado ensejo à elaboração de mecanismos de garantia de efetividade e legitimidade das instituições democráticas. Eis o caráter pedagógico que um problema de ordem moral concretamente verificado nos ambientes estatais pode ter. Muitas vezes, é a própria disfunção do exercício do poder político que impõe o desafio da construção dos instrumentos defensivos da integridade democrática, eis a gênese de diversos mecanismos de controle constitucional da moralidade pública.

\footnotetext{
${ }^{29}$ FILGUEIRAS, Fernando. Corrupção, democracia e legitimidade. Belo Horizonte: UFMG, 2008, p. 195-200.

${ }^{30}$ Nesse sentido, a análise de Sartori: “Además, aquí debemos tener cuidado con las generalizaciones. Es cierto que en América Latina hay corrupción rampante. En1993, el presidente de Brasil, Collor, y además Pérez, el presidente de Venezuela, fueron obligados a dejar el cargo al acusárles de corruptos. La corrupción es igualmente un grave problema en Argentina y en muchos otros países latinoamericanos. En Europa, el sistema de partidos italianos há sido literalmente barrido del escenario, também en 1993, por los escândalos de corrupción. Asimismo, en los años recientes, Japón há sido afectado por los escândalos monetários políticos” (SARTORI, Giovanni. Ingeniería constitucional comparada, cit., p. 162).

31 "O poder tem em si mesmo um estigma, e apenas os santos entre os detentores do poder - quando se pode encontrá-los - seriam capazes de resistir à tentação de abusar do poder." LOEWENSTEIN, Karl. Teoría de la constitución. Tradução de Alfredo Gallego Anabitarte. Barcelona: Ediciones Ariel, 1957, p. 28.
} 
Feitas todas essas considerações preliminares, vê-se com mais clareza em que contexto se coloca o estudo que se segue. O art. 55, II, da Constituição, ao prever a aplicação da penalidade de perda de mandato para o membro do Poder Legislativo que proceda de modo incompatível com o decoro parlamentar, estabelece de fato mecanismo de defesa institucional. Nosso objetivo, então, será determinar os limites constitucionais e infraconstitucionais do exercício da competência estabelecida no art. 55, II, da Constituição. Afinal, a decretação de perda de mandato por quebra de decoro, como qualquer competência no campo jurídico, está delimitada por balizas que são intransponíveis pelos agentes políticos que exercem esse poder.

Como se vê, a problematização temática de nossa pesquisa reside, precisamente, na questão da verificação de como e quando o processo de cassação de mandato por quebra de decoro parlamentar promovido pelo Poder Legislativo está apto a produzir todos os efeitos previstos pelo ordenamento sem ofensa a preceitos e princípios constitucionais e infraconstitucionais. Implica, assim, a determinação da própria gênese, sentido, significado e conteúdo dessa competência, em outras palavras, demanda a resposta do para quê e do por que da existência dessa hipótese de decretação de perda de mandato tanto no âmbito da Constituição (com isso, acha-se a própria finalidade do instituto) quanto no delineamento do modo como tal competência deve ser exercida a partir dos próprios parâmetros constitucionais e infraconstitucionais.

Com efeito, por tratarmos na presente pesquisa de uma competência exclusiva atribuída ao Poder Legislativo, o seu desenvolvimento acaba nos levando a uma discussão relacionada ao princípio da separação de poderes, já que, ao delinear os contornos do instituto da cassação por quebra de decoro, acabamos por delimitar os próprios limites da atuação jurisdicional no controle do exercício dessa competência.

A decisão sobre a cassação de mandato por quebra de decoro envolve elementos de apreciação de ordem política; por isso, em geral, é vedado ao Poder Judiciário realizar o mesmo tipo de apreciação no âmbito de sua competência, que deve se limitar a uma análise mais estritamente jurídica. Tal distinção entre aspectos políticos e jurídicos possui claramente um caráter de pura abstração; contudo, é preciso levar em conta essa perspectiva, para que possamos aferir em nossa análise a ocorrência ou não da ofensa ao princípio constitucional da separação de poderes (art. $2^{\circ}$ da Constituição Federal). 
Impende verificar que o nosso objeto de estudo evidencia ao primeiro olhar do analista um entrelaçamento entre aspectos jurídicos, éticos e políticos. $\mathrm{Na}$ perspectiva jurídica, compreende-se que a cassação de mandato por quebra de decoro é instituto objetivamente identificável no plano do ordenamento jurídico constitucional; logo, enquanto objeto a ser estudado, encontra-se sob o âmbito das Ciências Jurídicas, especificamente da Ciência do Direito Constitucional. No entanto, quando analisamos as finalidades, os efeitos e modos de efetivação do instituto, é possível observar os vínculos que o unem ao campo ético-político.

Configurando um instrumento de proteção da integridade do próprio Parlamento, enquanto instituição estatal legitimada para o exercício do poder democrático, a cassação por quebra de decoro tem o efeito concreto de desfazimento do status político do parlamentar faltoso, isto é, desfaz a própria decisão soberana do povo. Nesse sentido, as finalidades e os efeitos são flagrantemente políticos: a desconstituição da representação política democrática. Como se vê, essa situação político-jurídica tem um caráter excepcional, ${ }^{32}$ pois, no quadro do exercício normal do poder estatal, os representantes políticos parlamentares gozam de um período de mandato preestabelecido pela Carta Política: quatro anos para deputados, a teor do art. 44, parágrafo único, da Constituição, e oito anos para o senador, consoante art. $55, \S 1^{\circ}$, da Constituição, uma vez que somente de maneira excepcional é desfeita a relação de representação política.

Já o modo como a deliberação sobre a cassação por quebra de decoro se realiza implica uma análise da ocorrência do motivo ou causa para a decretação da perda do mandato, enfatizando a necessidade da compreensão do que se pode entender por "procedimento incompatível com o decoro". Demanda, destarte, uma definição mínima do que seja "decoro" ou "conduta ofensiva à dignidade parlamentar"; sem esse pressuposto não há como tornar viável a aplicação do instituto da cassação nos termos do art. 55, II, da Constituição. Por derradeiro, a questão resvala nos meandros da ética e da moral, pois o decoro vincula-se à ideia-guia do comportamento ético no exercício da função parlamentar. ${ }^{33}$

Apesar dessa interpenetração entre elementos jurídicos, políticos e éticos na configuração do instituto, o desenvolvimento analítico de nosso estudo girará em torno do

\footnotetext{
32 FERREIRA FILHO, Manoel Gonçalves. Comentários à Constituição brasileira de 1988. Saraiva: São Paulo, 1992, p. 55. Ver também SILVA, José Afonso da. Comentário contextual à Constituição. Malheiros: São Paulo, 2006, p. 423.

${ }^{33}$ SILVA, José Afonso da. Comentário contextual à Constituição, cit., p. 424.
} 
modo como o mecanismo da cassação por conduta incompatível com o decoro foi albergado pelo ordenamento jurídico nacional. Assim, os elementos ligados ao universo da ética e da política, como esferas puras e autônomas do conhecimento, serão trazidos em nossa análise na medida em que possam subsidiar a elucidação e a compreensão didática e propedêutica do instituto jurídico da cassação, sem que, com isso, ocorra desvio dos objetivos propostos, nitidamente de caráter técnico-jurídico. Diga-se: os aspectos políticos e éticos serão desenvolvidos considerando os parâmetros adotados pela Constituição e pelas normas infraconstitucionais que regem a decretação da perda de mandato por quebra de decoro. Não assumimos qualquer responsabilidade de aprofundamento das questões que se vinculem à política e à ética em nosso estudo.

O sentido de desenvolvimento de nosso trabalho é a busca de elementos teóricos interpretativos jurídicos para que sirva de suporte à aplicação (prática) do mecanismo da cassação de mandatos por quebra de decoro na dinâmica da vida concreta estatal, ${ }^{34}$ e não a construção de uma deontologia ético-política do que seria cabível a uma atuação na esfera da representação política parlamentar.

Importante a essa altura ressaltar que, quando apontamos como campo objetivo de nossa pesquisa não só os preceitos e princípios constitucionais que regem a cassação de mandato por quebra de decoro mas também as prescrições de natureza infraconstitucional, tal perspectiva de desenvolvimento analítico nos leva diretamente ao estudo dos Regimentos Internos de ambas as Casas legislativas. ${ }^{35}$ Consoante o $\S 1^{\circ}$, do art. 55, da Constituição Federal, os Regimentos Internos da Câmara e do Senado podem especificar hipóteses de perda de mandato por quebra de decoro para além daquelas previstas no próprio texto constitucional, quais sejam: o abuso de prerrogativas asseguradas ao membro do Congresso Nacional e a percepção de vantagens indevidas.

\footnotetext{
${ }^{34}$ Essa é uma perspectiva clássica de abordagem jurídica, e sobre ela Weber apresenta as seguintes análises: “A consideração jurídica ou, mas precisamente, a dogmático-jurídica, propõe-se a tarefa de investigar o sentido correto de normas cujo conteúdo apresenta-se como uma ordem que pretende ser determinante para o comportamento de um círculo de pessoas de alguma forma definido, isto é, de investigar as situações efetivas sujeitas a essa ordem e o modo como isso ocorre. Para esse fim, assim procede: partindo da vigência empírica indubitável daquelas normas, procura classificá-las de modo a encaixá-las num sistema sem contradição lógica interna. Esse sistema é a ordem jurídica no sentido jurídico da palavra" (WEBER, Max. Economia e sociedade. Tradução de Gabriel Cohn. Brasília: Editora da UnB, 2009. v. 1, p. 209).

${ }^{35}$ Os Regimentos Internos dizem respeito ao poder de auto-organização atribuído pela Constituição a cada uma das Casas legislativas (art. 51, III, e art. 52, XII, da Constituição Federal).
} 
Imperioso será também o estudo dos Códigos de Ética e Decoro Parlamentar do Senado Federal e da Câmara dos Deputados, ${ }^{36}$ uma vez que estes têm objetivamente natureza regimental e trazem em seus respectivos corpos normativos hipóteses de condutas incompatíveis com o decoro parlamentar, bem como regras procedimentais para a decretação da perda do mandato. Além disso, são os Códigos de Ética e Decoro Parlamentar que instituem os Conselhos de Ética e Decoro Parlamentar no âmbito de ambas as Casas legislativas.

Importante ressaltar que não trataremos no presente estudo do modo como a cassação por ofensa ao decoro ocorre no âmbito dos Legislativos estaduais e municipais - nossa pesquisa centra-se no modelo adotado pela Constituição de 1988, isto é, o da cassação de mandato na Câmara dos Deputados e no Senado Federal.

Partindo do pressuposto de que o objetivo desta pesquisa é explorar aspectos jurídicos constitucionais e infraconstitucionais da competência para a cassação de mandatos parlamentares por quebra de decoro estabelecida pelo art. 55, II, da Constituição Federal, torna-se imperioso tratar de alguns tópicos, por exemplo: natureza e características do mandato parlamentar; formas de aquisição e de perda do mandato; natureza jurídica do instituto da cassação por quebra de decoro e sua origem e evolução no constitucionalismo nacional; determinação do conceito de decoro parlamentar; limites do controle jurisdicional das decisões que decretam a perda do mandato por quebra de decoro; efeitos da renúncia do mandato antes de finalizado o processo de cassação; determinação sobre as situações aptas a ensejar a cassação por quebra de decoro tanto no que concerne ao momento de sua ocorrência quanto em relação ou não com o exercício do mandato; procedimentos adotados no âmbito dos Conselhos de Ética e Decoro Parlamentar da Câmara e do Senado.

Devemos reconhecer que são raras as obras publicadas que tratam especificamente do instituto da cassação de mandato por quebra de decoro previsto no art. 55, II, da Constituição, que por si só foi um obstáculo razoável para o desenvolvimento da pesquisa que ora apresentamos. Ressalte-se que, dentre os textos pesquisados, em regra, não há qualquer análise quanto aos Códigos de Ética e aos procedimentos que são adotados no âmbito dos Conselhos de Ética e Decoro Parlamentar do Senado e da Câmara quando da instauração dos processos

${ }^{36}$ A Resolução n. 25/2001 instituiu o Código de Ética e Decoro Parlamentar da Câmara dos Deputados. Já o Código de Ética e Decoro Parlamentar do Senado Federal foi estabelecido pela Resolução n. 20/93. 
ético-disciplinares. Dessa forma, acabamos trilhando caminho tortuoso com pouca ou quase nenhuma referência teórico-analítica específica, servindo-nos, muitas vezes, de análises jurisprudenciais, que também gozam de certa escassez quanto ao tema. Além disso, não deixamos de nos posicionar quanto a questões importantes, como a possibilidade de cassação de parlamentar por conduta ofensiva ao decoro ocorrida durante licenciamento para o exercício do cargo de Ministro de Estado ou por comportamento anterior ao exercício de qualquer mandato. 


\section{PARTE I \\ MANDATO PARLAMENTAR E CASSAÇÃO POR QUEBRA DE DECORO: NOÇÕES GERAIS.}

\section{CAPÍTULO 1 - DO MANDATO PARLAMENTAR}

Reza a Constituição Federal de 1988 que a República Federativa do Brasil constitui-se em Estado democrático de direito e que, embora todo o poder pertença ao povo, seu exercício se dá precipuamente por meio de representantes eleitos. ${ }^{37}$ Com isso, o texto constitucional estrutura e organiza o poder estatal a partir da pressuposição abstrata da existência de dois lócus ou esferas distintas da vida política, mas que guardam um alto grau de interação: uma esfera de origem do poder, que, a princípio, funciona como potência, o povo, e outra de exercício do poder, os representantes eleitos.

$\mathrm{O}$ instituto jurídico do mandato parlamentar tem sua gênese profundamente relacionada a essa distinção de esferas de poder que dá ensejo à representação política. $\mathrm{Na}$ realidade, só há representantes políticos exercendo concretamente mandatos no âmbito dos parlamentos porque se supõe que os representados, titulares legítimos da soberania popular, estão ausentes do cenário político - stricto sensu -, de modo que precisam se fazer representar. ${ }^{38} \mathrm{~A}$ análise teórica que dá sustentação a essa diferenciação entre origem do poder e seu exercício está na inequívoca constatação de que nos Estados constitucionais contemporâneos, seja pelo tamanho de suas populações, seja pela complexidade das relações

37 “Art. $1^{\text {o }}$ A República Federativa do Brasil, formada pela união indissolúvel dos Estados e Municípios e do Distrito Federal, constitui-se em Estado democrático de direito e tem como fundamento: I - a soberania; II - a cidadania; III - a dignidade da pessoa humana; IV - os valores sociais do trabalho e da livre-iniciativa; V - O pluralismo político. Parágrafo único. Todo o poder emana do povo, que o exerce por meio de representantes eleitos ou diretamente, nos termos desta Constituição."

${ }^{38}$ Segundo Hamon, Troper e Burdeau, "Na linguagem comum, fala-se de representação quando um objeto possui algumas características principais semelhantes às de outro objeto, de tal modo que se possa reconhecer essa semelhança e identificar o primeiro como uma imagem do segundo. Diz-se que ele torna presente esse segundo objeto, que ele o re-presenta" (HAMON, Francis; TROPER, Michel; BURDEAU, Georges. Direito constitucional. Barueri: Manole, 2005, p. 165). Explicitando politicamente o conceito, salienta Schmitt que "Representar es hacer perceptible y actualizar un ser imperceptible mediante un ser de presencia pública. La dialéctica del conecpto está en que se supone como presente lo imperceptible, al mismo tiempo que se le face presente" (SCHMITT, Carl. Teoría de la constitución. Tradução de Francisco Ayala. Madrid: Alianza Universidad, 2009, p. 209). Nesse passo, afirma também Jellinek: "Se entiende por representación la relación de una persona con otra o varias, en virtud de la cual la voluntad de la primera se considera como expresión inmediata de la voluntad de la última, de suerte que juridicamente aparecen como una sola persona" (JELLINEK, Georg. Teoría general del Estado. Tradução de Fernando de los Rios. México: Fondo de Cultura Económica, 2004, p. 506). 
sociais que encerra ou pela vastidão dos territórios, não há possibilidade prática para que o exercício do poder se dê diretamente por atuação de todos os cidadãos em conjunto. É esse um dos pontos centrais da clássica e afamada argumentação de Montesquieu em sua obra o Espírito das leis, de 1748, conforme se vê na passagem a seguir transcrita:

Num Estado livre, todo homem que supostamente tem uma alma livre deve ser governado por si mesmo, seria necessário que o povo em conjunto tivesse o poder legislativo. Mas, como isto é impossível nos grandes Estados e sujeito a inconvenientes nos pequenos, é preciso que o povo faça através de seus representantes tudo o que não puder fazer por si mesmo $(\ldots)^{39}$

A grande vantagem dos representantes é que eles são capazes de discutir os assuntos. O povo não é nem um pouco capaz disto, o que constitui um dos grandes inconvenientes da democracia.

Emmanuel Joseph Sieyés, vivenciando o processo revolucionário francês do final do século XVIII, pôde, em seu opúsculo Qu'est-ce que le Tiers État?, interpretar a realidade política de forma similar:

\footnotetext{
Os associados são muito numerosos e estão dispersos em uma superfície muito extensa para exercitar eles próprios facilmente sua vontade comum. O que fazem? Separam tudo o que para velar e prover é preciso as atenções públicas, e confiam o exercício desta porção da vontade nacional, e, consequentemente, do poder, a alguns dentre eles. Essa é a origem de um governo exercido por procuração. ${ }^{40}$
}

Assim é que a fundamentação argumentativa da representação política opera tanto na direção de solucionar um problema de ordem prática, a impossibilidade da união de todos em praça pública para decidir sobre questões de Estado, bem como um problema de ordem substancial, o da incapacidade do povo em geral de tratar sobre os negócios públicos de forma permanente. Em síntese, temos efetivamente que a representação política acaba configurando uma "mecânica que visa operacionalizar a democracia que, hoje, afigura-se impraticável pela via direta". 41

${ }^{39}$ MONTESQUIEU, Charles-Louis de Secondat. O espírito das leis. Tradução de Cristina Murachco. São Paulo: Martins Fontes, 2005, p. 170-171.

${ }^{40}$ SIEYÉS, Emmanuel Joseph. A constituinte burguesa: qu'est-ce que le Tiers État? Tradução de Norma Azeredo. São Paulo: Lumen Juris, 1997, p. 92.

${ }^{41}$ CAGGIANO, Monica Heman Salem. Direito parlamentar e direito eleitoral. São Paulo: Manole, 2004 , p. 02. Sobre esse aspecto, diz Michels: “... o argumento mais poderoso contra a soberania da massa é tirado da 
Com efeito, essa construção teórica tem como resultado a negação do modelo herdado da Antiguidade grega, representando um afastamento da democracia em sua versão do governo direto pelos cidadãos. A democracia moderna tem como elemento característico e preponderante a representatividade, elemento que, se não foi completamente desconhecido pela Antiguidade, não teve a qualidade de ser sua marca distintiva enquanto sociedade politicamente organizada. ${ }^{42}$

Objetivando exatamente esse afastamento da política antiga, os pais do federalismo estadunidense opuseram à democracia (pura) a ideia de república, dando a esse último termo o sentido de poder político exercido por representantes. Destarte, diz Madison que a verdadeira distinção dessas duas formas é o fato de que:

... em uma democracia, o povo constitui e exerce pessoalmente o governo; na república, o povo se reúne e a administra através de seus representantes e agentes. Consequentemente, uma democracia ficará confinada em um pequeno espaço, enquanto uma república pode estender-se sobre uma larga região. ${ }^{43}$

Toda essa análise remonta, por óbvio, ao advento dos Estados modernos, no qual encontramos a estruturação de uma máquina estatal (aparelho de Estado) centralizada que

impossibilidade mecânica e técnica de sua realização" (MICHELS, Robert. Os partidos políticos. Tradução de Hamilton Trevisan. São Paulo: Senzala, s/d, p. 10).

${ }^{42}$ Nossa referência aqui são as análises realizadas por Jellinek, para quem "A las afirmaciones, repetidas más a menudo, respecto al derecho de los antiguos Estados, se suele añadir la de que les era completamente extrana la idea de la representación. Pero esto sólo es exacto en relación a la actividad de los órganos supremos de las repúblicas: la asamblea popular y el consejo. [...] Pero cuando queda excluida la reunión general del pueblo, entonces, tanto en Grecia com en Roma, vemos aparecer con toda claridad para los actos que es preciso llevar a cabo, la idea de la representación" (JELLINEK, Georg. Teoría general del Estado, cit., p. 507-508). Essa análise de Jellinek se adéqua bem à afirmação de Montesquieu de que é "preciso prestar atenção à diferença muito grande que existe entre dizer que uma certa qualidade, modificação da alma, ou virtude, não é o motor que faz agir um governo e dizer que ela não se encontra neste governo" (MONTESQUIEU, Charles-Louis de Secondat. $O$ espírito das leis, cit., p. 01). Em José Afonso da Silva encontramos a seguinte posição: "A ideia de representação foi, pois, o móvel não só do surgimento, mas também da estruturação do Poder Legislativo. Este não existiu na Antiguidade porque a ideia de representação não existia" (SILVA, José Afonso. Comentário contextual à constituição. São Paulo: Malheiros, 2010, p. 384). Sartori, reforçando a distinção entre democracia antiga e moderna, frisa exatamente que "Quando falamos sobre o sistema grego como um Estado democrático, estamos sendo tremendamente imprecisos, tanto terminológica quanto conceptualmente. Porquanto, o que caracteriza aquela democracia era ser sem Estado, no sentido preciso de que ela dispensava o Estado e era uma democracia na medida em que o demos substituía o Estado. A ideia de um Estado democrático para os gregos era inconcebível; e se eles tivessem sido capazes de concebê-la, isso lhes teria parecido ser uma contradição em termos" (SARTORI, Giovanni. Teoria democrática. São Paulo: Fondo de Cultura Económica, 1965, p. 267).

${ }^{43}$ HAMILTON, Alexander; MADISON, James; JAY, John. O federalista. Tradução de Heitor de Almeida Herrera. Brasília: Universidade de Brasília, 1984, p. 173. 
dentro de determinado agrupamento humano logra êxito em monopolizar o uso da violência legítima, ${ }^{44}$ isto é, refere-se a um momento no qual o Estado já aparece como algo distinto da sociedade. É este, sem dúvida, o ponto inicial para o desenvolvimento dos Estados constitucionais que conhecemos contemporaneamente, bem como para o desdobramento do próprio instituto do mandato representativo moderno. Reforçando essa perspectiva, convém transcrever as palavras de José Afonso da Silva: "o mandato representativo é criação do Estado Liberal burguês, como um meio de manter distinto Estado e sociedade e como mais uma forma de tornar abstrata a relação governo/povo". 45

Conclui-se, assim, que o mandato político implica o exercício representativo do poder; logo, não em nome próprio, mas em nome de outrem que tem sua titularidade originária, o povo. Encerra, pois, o instituto do mandato parlamentar uma relação dialética que é, sem dúvida alguma, o nó das polêmicas doutrinárias e políticas sobre o tema, o qual se revela na constatação de que os representantes do Parlamento não só tutelam os interesses dos mandantes mas, ao mesmo tempo, também os governam. ${ }^{46}$ Nesses termos, seguem as palavras de Manin, Przeworski e Stokes:

\begin{abstract}
Democracy is a form of rule. Even in direct democracy, decisions of a majority are binding on everyone, including the minority that finds them against their opinions or interests. In a representative democracy - our form of government - these decisions are made by elected representatives and implemented by appointed officials to whom the representatives delegate some of the tasks of governing. ${ }^{47}$
\end{abstract}

Esse fenômeno pode ser expresso pela ideia de que, na relação de representação política, os que obedecem o fazem mandando e os que mandam estão apenas a obedecer. ${ }^{48}$

${ }^{44}$ WEBER, Max. Ciência e política: duas vocações. Tradução de Leonidas Hegenberg e Octany Silveira da
Mota. São Paulo: Cultrix, 1983 .
45 SILVA, José Afonso da. Poder constituinte e poder popular: estudos sobre a Constituição. São Paulo:
Malheiros, 2007, p. 48 .
46 SARTORI, Giovanni. A teoria da representação no Estado representativo moderno. Tradução de Ernesta
Gaetani e Rosa Gaetani. Minas Gerais: Revista Brasileira de Estudos Políticos, 1962, p. 28.
47 "Democracia é uma forma de governo. Mesmo na democracia direta, as decisões da maioria são obrigatórias
para todos, incluindo a minoria que as considerarem contrárias à suas opiniões ou interesses. Na democracia
representativa - nosso regime político - essas decisões são tomadas por representantes eleitos e implementadas
pelos funcionários nomeados a quem os representantes delegarem algumas das tarefas de governo." [tradução
livre do autor] MANIN, Bernard; PRZEWORSKI, Adam; STOKES, Susan C. Democracy, accoutability and
representation. Cambridge: Cambridge University Press, 2003, p. 01.
48 Nesse sentido é que Dussel se refere ao poder exercido pelo representante político como um poder de
obediência (DUSSEL, Enrique. 20 Teses de política. Buenos Aires: Consejo Latinoamericano de Ciências 
Em adendo, importa salientar que o mandato político parlamentar configura uma representação do tipo eletiva, cuja investidura para o exercício do poder se dá por meio de eleições que têm por objetivo conferir aos representantes "em corpo o poder de querer pela comunidade, em nome dela, a quem se imputa a manifestação da vontade deles." 49 Lembre-se, contudo, de que a nossa Constituição de 1988 estabelece o princípio da representação política eletiva como parâmetro não só para o Poder Legislativo mas também para o Executivo, sendo que a regra se aplica a todos os níveis governamentais, União, Estados, Distrito Federal e Municípios. Feitas essas considerações iniciais, impende determinar os contornos característicos do mandato representativo na esfera do Parlamento a partir dos princípios ontológicos que o regem, passando, então, aos balizamentos constitucionais positivos.

Não podemos olvidar ao fato de que o desdobramento do mandato representativo e a respectiva descoberta de seus delineamentos jurídicos e políticos característicos exigem de imediato sua confrontação teórica com o mandato existente no âmbito das relações privadas. Diga-se, é preciso verificar em que medida esses institutos se aproximam e se distanciam, deste confronto é que surgem com mais segurança as características inerentes ao mandato.

Deixemos, pois, de chofre assente que se por um lado a nomenclatura "mandato representativo" nos remete esquematicamente para a figura do mandato de direito privado, isso apenas denota uma intentio inicial do instituto, ${ }^{50}$ não podendo, contudo ser estes tipos jurídicos confundidos, afinal um diz respeito a relações firmadas no campo público político e o outro, como já dito, nos remete para relações do mundo privado. Devemos, destarte, constatar que essa utilização de termos análogos não foi obra do acaso, pelo contrário foi a partir das práticas institucionalizadas pelo mandato privado que se engendrou o mandato público político, é isso que nos mostra o encadeamento histórico que nos leva ao mandato representativo moderno, ${ }^{51}$ e particularmente ao mandato parlamentar.

Sociales - CLASCO. São Paulo: Expressão Popular, 2007, p. 38). Uma reflexão dessa situação nos é dada por Schmitt: "Por lo tanto, la fuerza o autoridad de los que dominan o gobiernan no há de apoyarse en cualesquiera altas cuaidades inacce al pueblo, sino sólo en la voluntad, el mandato y la confianza de los que han de ser dominados o gobernados, que de esta manera se gobiernan en realidad a si mísmos" (SCHMITT, Carl. Teoría de la constitución., cit., p. 231).

${ }^{49}$ FERREIRA FILHO, Manoel Gonçalves Ferreira. Princípios fundamentais de direito constitucional. São Paulo: Saraiva, 2010, p. 64.

${ }^{50}$ SARTORI, Giovanni. A teoria da representação no Estado representativo moderno, cit., p. 15.

${ }^{51}$ DALLARI, Dalmo de Abreu. Elementos de teoria geral do Estado. São Paulo: Saraiva, 2009, p. 132. 
Conceitualmente na configuração do mandato vigente na esfera das relações privadas o representante apenas exprime uma vontade anteriormente existente e pré-definida, não tendo espaço para uma apreciação larga no momento em que exerce a representação ipsis litteris a vontade do representado. Nessa perspectiva, diz Manoel Gonçalves Ferreira Filho, o representante é um mero porta-voz do representado, ${ }^{52}$ sendo que tal tipo de representação pode ser classificada como uma representação-expressão, ${ }^{53}$ no qual o mandatário apenas expressa por extensão a vontade dos representados.

Um exemplo concreto e didático dessa situação nos dá Sampaio Doria:

\begin{abstract}
$\mathrm{Na}$ impossibilidade de uma administração directa, comete, por exemplo, o senhorio de prédios urbanos a pessoa de sua confiança o encargo de alugá-los, conservá-los, e pagar os impostos de arrendamento, despesas de conservação e de impostos, e o recolhimento da renda líquida, mês por mês. ${ }^{54}$
\end{abstract}

Vê-se que o objeto do mandato transferido ao mandatário é completamente (ou quase) preestabelecido e determinado; sabe-se de antemão o que o mandatário pode realizar enquanto representante de interesse alheio de quem não pode se fazer presente - com efeito, o mandatário não pode desviar-se do cumprimento estrito das instruções contidas no mandato, devendo atuar dentro do limite em que este lhe foi atribuído.

Historicamente é essa a típica relação estabelecida no período medieval absolutista no qual os representantes do reino, ao se apresentarem perante o Conselho do $\mathrm{rei}^{55}$ como mandatários, tinham em mãos instruções preestabelecidas determinando como tratar cada assunto com o soberano. Importante nesse sentido as lições de Manoel Gonçalves Ferreira Filho:

${ }^{52}$ FERREIRA FILHO, Manoel Gonçalves. Do processo legislativo. São Paulo: Saraiva, 2002, p. 64.

${ }^{53}$ FERREIRA FILHO, Manoel Gonçalves Ferreira. Princípios fundamentais de direito constitucional, cit., p. 57.

${ }^{54}$ DORIA, A. de Sampaio. Direito constitucional. Teoria geral do Estado. São Paulo: Max Limonad, 1962. v. I, t. II, p. 638.

${ }^{55}$ Tanto no continente europeu como na Inglaterra foram muitos os modos como esses Conselhos medievais se desenvolveram. Sobre esse aspecto afirma Carlos Zorro Sanchez que "El diverso desarrollo de las comunidades europeas en la Alta Edad Media, no sirvió de obstáculo a la existencia de gérmenes comunes en la mayor parte de ellas, habiendo llegado un momento histórico, hacia los Siglos XII y XIII, en que la configuración política de los principales estados europeos era bastante similar: el decadente feudalismo había dado base para el surgimiento de las monarquias nacionales, paralelamente a las cuales se desarrollaban consejos y asambleas; fué la época del 'Concilium' inglês, de los primeros 'Estados' franceses y de la aparición de las 'Cortes' españolas y las 'Dietas' alemanas" (ZORRO, Carlos Sanchez. El parlamento. Sus orígenes y su posterior evolución. Bogotá: Universidad Javeriana, Editorial Omnia, 1965, p. 09). 
$\mathrm{Na}$ representação medieval é flagrante a pressuposição de que os representados têm no representante um mero instrumento de expressão de sua vontade. Isso se vê da estrutura jurídica que informa a representação nas instituições da Idade Média. Claramente se nota aí que a representação é, então, a transposição do mandato civil para o plano político, o plano do Direito Público. O representante é escolhido por uma comunidade determinada, para exprimir num conselho a vontade determinada dos representados sobre questões determinadas. ${ }^{56}$

Nesses termos, compreende-se que o instituto do mandato no modo em que foi concebido para servir na esfera política durante o período medieval tem seu fundamento teórico jurídico no instrumento de representação privada. ${ }^{57}$ Nesse momento histórico, reconhece-se esse mandato como de caráter imperativo, entendendo por tal assertiva que o "eleitor pode prescrever ao eleito o modo pelo qual este terá de agir em seu nome", ${ }^{2}$ responsabilizando-o em caso de descumprimento do mandato recebido, contexto em que passa a ser, portanto, de regra, a sua revogabilidade.

Já o contexto histórico que assinala no campo político a passagem da vigência do mandato imperativo para o mandato representativo moderno (como o conhecemos em suas linhas gerais) se dá exatamente no período em que o Parlamento deixa de ser um órgão frente ao poder e passa a ser um órgão do poder, ${ }^{59}$ ou melhor, no momento em que ocorre a integração burguesa no polo de poder do Estado, cindindo o poder. ${ }^{60}$ Essa situação concreta não só exige uma nova elaboração da teoria da representação mas também determina a consolidação do princípio da separação de poderes como fundamento do Estado de direito

${ }^{56}$ FERREIRA FILHO, Manoel Gonçalves. Do processo legislativo, cit., p. 64. Interessante notar com Karl Loewenstein que "La teoría más moderna, y probablemente la más correcta, apunta a la recepción por las organizaciones seculares de las técnicas representativas que desde hacía largo tiempo estaban establecidas en la Iglesia católica y en las ordenes religiosas" (LOEWENSTEIN, Karl. Teoría de la constitución. Tradução de Alfredo Gallego Anabitarte. Barcelona: Ediciones Ariel, 1957, p. 59).

${ }^{57}$ MENDES, Antonio Carlos. Introdução à teoria das inelegibilidades. São Paulo: Malheiros, 1994, p. 44.

${ }^{58}$ PORTO, Walter Costa. Dicionário do voto. São Paulo: Giordano, 1995, p. 230.

${ }^{59}$ SARTORI, Giovanni. A teoria da representação no Estado representativo moderno, cit., p. 22.

${ }^{60}$ Interessante para essa análise as palavras de Duverger: "El asceno de la burguesia hace que quiera cada vez más no sólo el poder econômico, que ya lo tiene (en su conjunto es mucho más rica que la aristocracia gracias a las sucesivas revoluciones industriales) sino también la igualdad social y el poder político [...]. Fuera de este marco el sistema inglês probará ser muy útil ya en el fondo existen dos órganos, un rey que pertence a lo que llamaríamos en Francia el antiguo régimen, es decir el viejo sistema, la manera de pensar aristocrática en donde los hombres son desiguales por naturaleza [...]. En cambio la burguesia, que en Inglaterra como en Francia, se ligará el liberalismo político [...]; esta burguesía que va hacer de la soberania nacional su doctrina y su tema, encontrará en el Parlamento un órgano naturalmente creado para ella" (DUVERGER, Maurice. Apogeo y declinácion del sistema parlamentario. In: DUVERGER, Maurice; BRIDIER, Manuel. El sistema parlamentario. El poder real. Buenos Aires: Schapire Editor, 1973, p. 23). 
moderno. ${ }^{61}$ Estamos diante da ascensão burguesa ao poder, que teve como epicentro as revoluções inglesa do século XVII (Puritana de 1640 e Gloriosa de 1688) e francesa no século XVIII (1789).

Não por outro motivo Karl Loewenstein, ao analisar o surgimento da representação política moderna, afirma que: "Por ello, no es una mera coincidencia que la auténtica separación de las funciones esetatales y su atribución a separados detentadores del poder, tuvise que esperar hasta que la técnica de la representación fuese inventada, o mejor dicho, descubierta". ${ }^{62}$

Diante dessa nova compreensão do mandato imposta pelo advento das revoluções liberais burguesas, torna-se regra que o mandato seja exercido de forma livre, e não imperativa. As instruções medievais que vinculavam representante e representado já não são mais bem-vindas nesse novo panorama histórico político; segundo essa perspectiva, afirma Prelot: "L'exercise du mandat parlementaire ne consiste donc pas dans l'accomplissent des volontés de celui qui le confie, comme dans le droit privé, ou encore dans l'exécution des instructions recues lors des élections aux Etats géneraux, comme dans l'ancien droit”. 63

O deslocamento da representação imperativa para a livre se dá na mesma medida em que o representante não é mais considerado um representante direto dos mandatários, mas de toda nação, ou seja, foge-se de um vínculo concretamente existente e determinado para um vínculo de cunho abstrato e de grande indeterminação; afinal, não podemos deixar de nos perguntar, qual o objeto do mandato se este não está pautado em instruções definidas?

Com efeito, o mandato livre, em oposição ao mandato imperativo, implica uma representação-imputação na qual "a vontade do representante, melhor, do órgão representativo, é atribuída ao soberano, o povo". ${ }^{64}$ Nesses termos, não é o representante

${ }^{61}$ Nesse sentido é que Karl Marx pôs em evidência a teoria da separação de poderes como uma urgência concreta, ao firmar que, se "a dominação está dividida, mostra-se como ideia dominante a doutrina da divisão dos poderes” (MARX, Karl. A ideologia alemã. São Paulo: Grijalbo, 1977, p. 72).

62 "Por isso, não é uma mera coincidência que a autentica separação das funções estatais e sua atribuição a diferentes detentores do poder teve que esperar até que a técnica da representação fosse inventada, ou melhor, descoberta." [tradução livre do autor] LOEWENSTEIN, Karl. Teoría de la constitución, cit., p. 58. No mesmo sentido, FERREIRA FILHO, Manoel Gonçalves. Do processo legislativo, cit., p. 63.

63 "O exercício do mandato parlamentar, portanto, não consiste em realizar as vontades daquele que o delega, como no direito privado, ou ainda na execução de instruções recebidas nas eleições para a Estados gerais, como no antigo direito" [tradução livre do autor] PRÉLOT, Marcel. Institutions politiques et droit constitutionnel. Paris: Dalloz, 1963, p. 698.

${ }^{64}$ FERREIRA FILHO, Manoel Gonçalves Ferreira. Princípios fundamentais do direito constitucional. São Paulo: Saraiva, 2010, p. 63. 
político um mero porta-voz do representado (representação-expressão), mas tem ele liberdade de atuação para querer em nome da nação. Existe uma duplicidade de vontades não idênticas, ambas legítimas e com seus momentos próprios.

Um dos textos clássicos que marcam os contornos teóricos do mandato representativo moderno é o do pensador político inglês Edmund Burke, que, em 1774, em seu discurso aos eleitores de Bristol, pontuou enfaticamente a superação do modelo teórico do mandato imperativo.

Dar opinião é direito de todos os homens. A opinião dos eleitores é uma opinião de peso e respeito que um representante deve sempre se alegrar por ouvir e sempre examinar com a máxima atenção. Mas as instruções imperativas, os mandatos que o deputado está obrigado, de maneira cega e implícita, a obedecer, votar e defender, ainda que sejam contrárias às convicções mais claras de seu juízo e de sua consciência, são coisas totalmente desconhecidas nas leis do país e surgem de uma interpretação fundamentalmente equivocada de toda a ordem e respeito à nossa Constituição. O Parlamento não é um congresso de embaixadores que defendem interesses distintos e hostis, interesses que cada um de seus membros deve sustentar, como agente e advogado, contra outros agentes e advogados, mas uma assembleia deliberativa de uma nação, com um interesse: o da totalidade. ${ }^{65}$

Não podemos nos esquecer da contribuição de Montesquieu para essa discussão:

Não é necessário que os representantes, que receberam daqueles que os escolheram uma instrução geral, recebam outra particular sobre cada assunto, como se pratica nas dietas da Alemanha. É verdade que, desta maneira, a palavra dos deputados seria a melhor expressão da voz da nação; mas isto provocaria demoras infinitas, tornaria cada deputado o senhor de todos os outros, e nas ocasiões mais urgentes, toda a força da nação poderia ser retida por um capricho. ${ }^{66}$

No cenário político francês do final do século XVIII, encontramos o princípio do mandato livre traduzido na vedação ao mandato imperativo, não só como um objeto de discussão doutrinária mas, principalmente, como um dos elementos conformadores da ordem política da época, veja-se, nesse caso, o importante exemplo da Constituição de 1791, a qual

${ }^{65}$ BURKE, Edmund. Discurso aos eleitores de Bristol. Tradução de Cid Knipell Moreira. In: WEFFORT, Francisco C. (Org.). Os clássicos da política 2. São Paulo: Ática, 1995. p. 29.

${ }^{66}$ MONTESQUIEU, Charles-Louis de Secondat. O espírito das leis, cit., p. 171. 
estabelecia que "les représentants nommés dans les départements, ne seront pas représentants d'un département particulier, mais de la Nation entière, et il ne pourra leur être donné aucun mandat" (Título III, Cap. I, seção III, do art. $\left.7^{\circ}\right) .{ }^{67}$ De fato, a perspectiva da vedação ao mandato imperativo estava presente no panorama institucional francês desde a convocação dos Estados-Gerais ${ }^{68}$ pelo rei, em 1789, que impedia os deputados de receberem instruções rígidas de seus mandantes. ${ }^{69}$ A necessidade de reforçar a proibição do mandato imperativo fez com que o rei, em 23 de junho de 1789, por meio de ordenação, declarasse nula qualquer instrução recebida pelos deputados, proibindo, assim, todo mandato imperativo. ${ }^{70}$

A imagem que deve ser preservada dessas análises é precisamente a distinção entre um mandato de direito privado e o instituto do mandato representativo político. Há quem diga que a nomenclatura "mandato" ou "representação" não seja o modo mais adequado de se referir à relação existente entre destinatários e detentores do poder político no Estado contemporâneo, pois apenas muito forçosamente poderia se dizer que existe uma relação de representação no caso. Nesse sentido, Dalmo de Abreu Dallari salienta que "entendem alguns estudiosos que é impróprio falar-se em mandato político, o que, no seu entender, significa uma transposição inadequada de um instituto do direito privado para o âmbito do direito público". ${ }^{71}$

Sobre a questão, temos também a lição de Manoel Gonçalves Ferreira Filho:

A doutrina da representação, como a da soberania da Nação, de que decorre, se desenvolveu incontestavelmente a partir da desconfiança em relação à multidão e serviram eficientemente para o estabelecimento de assembleias "menos próximas do povo". É patente, portanto, que o mandato representativo, à luz da doutrina clássica da Revolução Francesa, longe está do mandato conhecido pelo Direito Privado. Entre ambos, só há em comum o agir em nome alheio,

67 "Os representantes designados dentro dos departamentos, não devem ser representantes de um determinado departamento, mas de toda a Nação, e ele não poderá ser dado nenhum mandato." [tradução livre do autor] Disponível em: <http://www.elysee.fr/president/la-presidence/les-textes-fondateurs/les-constitutions-depuis1791/les-textes-constitutionnels-anterieurs/la-constitution-du-3-septembre-1791.8872.html>. Acesso em: $26 \mathrm{dez}$. 2010.

${ }^{68}$ Sobre as origens dos Estados Gerais na França, Zorro diz: "En efecto, el nieto de San Luis, Felipe IV del Hermoso (1285-1314), embarcado en ruidosas desaveniencias com el Papa Bonifácioa VIII, quiso apoyarse en la burguesia que le era ampliamente favorable y la convoco en 1302 a una de las reuniones del 'Concilium' junto con la nobleza y el clero. En esta ocasión quedaron definitivamente configurados los Estados Generales, cuyas atribuciones, derivadas directamente del 'Concilium' que les habia servido de fundamento, podían reducirse a dos: una de caráter principal, la aprobación de impuestos, gabelas y contribuciones, y outra adicional, el desempeño de las inherentes a su calidad de cuerpo consultivo" (ZORRO, Carlos Sanchez. El parlamento, cit., p. 21).

${ }^{69}$ BONAVIDES, Paulo. Ciência política. São Paulo: Malheiros, 2003, p. 209.

${ }^{70}$ JELLINEK, Georg. Teoría general del Estado, cit., p. 513.

${ }^{71}$ DALLARI, Dalmo de Abreu. Elementos de teoria geral do Estado, cit., p. 132. 
o exprimir vontade que é juridicamente imputada a outrem. Basta isso para justificar a identidade de nome? Não faltam os que veementemente sustentam que não. ${ }^{72}$

Consideramos que essa assertiva sobre a impropriedade em classificar o mandato político como de natureza representativa só é correta se tomarmos o mandato privado como único a enfeixar uma verdadeira relação de representação, modo pensado, por exemplo, por Kelsen, ao dizer que o uso do termo representação para designar a atuação de órgãos eleitos pelo povo é linguisticamente incoerente, pois o máximo que pode haver nesses casos é uma ficção, e não uma representação propriamente dita, pois o mandato livre significa a perda de vínculo jurídico entre representantes e representados. ${ }^{73}$ Essa mesma ficção foi exposta nas críticas de Robert Michels ao sistema representativo: "Representar significa fazer aceitar, como sendo vontade da massa, aquilo que não é senão vontade individual". ${ }^{74}$

Nesse sentido, Hamon, Troper e Burdeau, não afastando completamente a ideia de representação, concluem, de acordo com a lição de Raymond Carré de Malberg, que a teoria que melhor abarca o fenômeno do mandato político não é tanto a ideia de representação, mas a da teoria do órgão:

... existe um ente, o soberano ou o Estado, que, como um homem, deseja e age mediante seus órgãos. Da mesma forma que as palavras que saem da boca de um homem a ele são imputadas, igualmente os atos que emanam do governo ou do Parlamento são imputadas ao Estado. Do mesmo modo que não se afirma que uma boca representa um homem, não se deve dizer que o Parlamento representa o soberano. Ele é seu órgão. ${ }^{75}$

\footnotetext{
${ }^{72}$ FERREIRA FILHO, Manoel Gonçalves. Do processo legislativo, cit., p. 70.

${ }^{73}$ KELSEN, Hans. Teoria pura do direito. Tradução de João Baptista Machado. São Paulo: Martins Fontes, 2006, p. 331-333. Observe-se que Kelsen visa pôr em relevo a falta de parâmetro científico jurídico para o estudo do mandato político e, com efeito, salienta que, "com a representação, não queremos significar senão que o indivíduo que realiza a função está juridicamente, ou ético-politicamente apenas, vinculado a realizar esta função no interesse do indivíduo ou dos indivíduos aos quais, precisamente por isso, essa função é atribuída" (KELSEN, Hans. Teoria pura do direito, cit., p. 333).

${ }^{74}$ MICHELS, Robert. Os partidos políticos, cit., p. 20. Deixemos claro que a base da crítica de Michels destoa em alguns aspectos da de Kelsen. Enquanto este último, ao não ver qualquer vínculo formal entre representantes e representados após o momento eleitoral, acaba por classificar a ideia de "representação" como uma fictio de natureza ideológico política, um cheque em branco dado ao representante político irresponsável para querer em nome da nação, Michels vê a ligação entre o corpo eleitoral e os eleitos no momento pós-eleitoral, mas acentua o caráter de minoritário daqueles que podem exercer real influência sobre os representantes.

${ }^{75}$ HAMON, Francis; TROPER, Michel; BURDEAU, Georges. Direito constitucional, cit., p. 167.
} 
A teoria do órgão resolve o problema da representação concebendo o instituto de forma objetiva e impessoal: têm-se apenas órgãos representativos da pessoa do Estado que não pode agir sem que atuem os representantes eleitos. Nesse contexto, o próprio eleitor realiza sua função em um órgão, e é exatamente essa a teoria adotada também por Jellinek “... el pueblo mismo no es una personalidad distinta del Estado, sino un órgano de este: el órgano supremo. [...] pero sus facultades se han reducido a colaborar en la formación de outro órgano". 76 Assim, não há efetivamente um vínculo de representação entre povo e representante político, mas funções exercidas em órgãos por determinação da Constituição. ${ }^{77}$

Da perspectiva estritamente jurídica, a teoria do órgão resolve de forma eficiente o problema da representação, remetendo as questões sempre para a ordem normativa que rege o exercício das funções e institui os órgãos estatais, mas, como bem salienta Giovani Sartori, do ponto de vista político, a polêmica não se vê solucionada, uma vez que a teoria do órgão "parte do interior do Estado e resolve o problema instalando-se imediatamente na Constituição e destruindo as ligações com os processos políticos que a condicionam do exterior" ${ }^{78}$ Adotada essa perspectiva, a eleição aparece como um mero momento formal de designação, e não como um ponto de inflexão política; a pessoalidade da relação entre sociedade e membros dos órgãos superiores do Estado desaparece, e o fundamento da ordem política que é a Constituição não pode ser compreendido satisfatoriamente, pois o órgão que lhe dá origem não pode, por óbvio, ser legitimado pelo próprio texto constitucional.

Não é o caso de aprofundarmos no desenvolvimento dessa problemática, intelectualmente excitante e sob a qual a doutrina já verteu um bom punhado de considerações, mas apenas deixar firmado que muitas polêmicas existem em relação ao tema, uma vez que, para a dinâmica do presente estudo, basta colocarmos em relevo as diferenciações entre o mandato político público e o mandato privado, para que suas naturezas jurídicas não sejam confundidas e possamos, assim, descortinar seus caracteres.

\footnotetext{
76 “...o povo em si mesmo não é uma personalidade separada do Estado, e sim um órgão desse: o órgão supremo [...] mas suas faculdades foram reduzidas para colaborar na formação de um outro órgão.” [tradução livre do autor] JELLINEK, Georg. Teoría general del Estado, cit., p. 518-519.

${ }^{77}$ JELLINEK, Georg. Teoría general del Estado, cit., p. 517.

${ }^{78}$ SARTORI, Giovanni. A teoria da representação no Estado representativo moderno, cit., p. 63.
} 


\subsection{Características}

O desenvolvimento do mandato representativo, a partir de seu substrato moderno público, põe em relevo certas características que impregnam o instituto e delineiam os seus contornos jurídicos. Dessa forma, vamos elencar alguns de seus caracteres que atualmente têm importância no âmbito do constitucionalismo, identificando seus influxos na esfera da Constituição de 1988, mais especificamente no que atina à instituição parlamentar.

Nesse passo, a primeira característica a ser evidenciada é a que dá ao mandato seu caráter livre, diga-se, o parlamentar é independente na determinação do que deve fazer, no modo como deve atuar, de qual caminho seguir, sendo vedado o exercício do mandato sob ordens além daquelas que a própria razão do representante ordenar. Presume-se, assim, que o exercício do mandato decorre dos "poderes que a Constituição confere ao representante, que lhe garantem autonomia da vontade". ${ }^{79}$

É, portanto, dessa característica que advém o impedimento ao mandato imperativo, cuja existência solaparia a liberdade parlamentar. Em síntese, impede-se que se engendre uma relação do tipo contratual entre eleitores e eleitos ${ }^{80}$ caso contrário, encontrar-se-ia ameaçada a ideia preponderante e essencial de que o mandato representativo tem um conteúdo geral, de que o parlamentar representa o povo ou nação como um todo. Assim, a generalidade é também uma das características essenciais dos mandatos políticos no âmbito do constitucionalismo contemporâneo; afinal, se fossem permitidos vínculos formais entre representantes do parlamento e membros da sociedade, parte do povo poderia restar não representada ou subrepresentada - com efeito, o discurso público e a atuação parlamentar se apresentariam diante opinião pública como particular.

Ao explorar o conteúdo da Constituição de 1988, não encontramos, como observa Auro Augusto Caliman, qualquer determinação vedando o mandato imperativo, ${ }^{81}$ conforme se verifica, por exemplo, na Constituição francesa, a qual estabelece, em seu art. 27, que todo mandato imperativo é nulo. Contudo, se nosso Texto Maior não impôs tal medida em forma de uma negativa, objetivamente constatável, devemos dizer que, do arcabouço normativo de suas

\footnotetext{
${ }^{79}$ SILVA, José Afonso da. Poder constituinte e poder popular: estudos sobre a Constituição, cit., p. 48.

${ }^{80}$ AVRIL, Pierre; GICQUEL, Jean. Droit parlementaire. Paris: Montchrestien, 2004, p. 32.

${ }^{81}$ CALIMAN, Auro Augusto. Mandato parlamentar: aquisição e perda antecipada. São Paulo: Atlas, 2005 , p. 41.
} 
estipulações, podemos, certamente, concluir pelas características da liberdade e da generalidade do mandato.

$\mathrm{O}$ art. $1^{\circ}$ da Constituição é claro ao configurar o representante político como um representante do povo em geral, e não deste ou daquele cidadão eleitor em particular. No mesmo sentido, cite-se o art. 45, ao ditar que a Câmara dos Deputados é composta por representantes do povo, embora seus membros sejam eleitos nas circunscrições estaduais. ${ }^{82}$ No mais, observe-se que o art. 46 estabelece que o Senado Federal é composto por representantes dos Estados e do Distrito Federal, reafirmando a generalidade do mandato no âmbito do respectivo ente federativo com representação na Casa. ${ }^{83}$

À luz de toda essa especificidade constitucional é que podemos compreender também os ditames do art. 53, o qual garante àquele que exerce um mandato no âmbito da Câmara dos Deputados ou do Senado Federal a inviolabilidade civil e penal por quaisquer opiniões, palavras e votos emitidos no exercício do mandato. De outra mão, temos ainda a imposição das incompatibilidades no art. 54, as quais impedem o parlamentar de exercer certas atividades e funções que impliquem conflitos de interesses com o exercício de sua função política. A conclusão é inevitável: ao parlamentar é dada ampla independência para o exercício de sua função, tudo com o intuito de garantir uma representação geral, desvinculada de qualquer interesse a princípio particularizado e pessoal. Impende observar que essa é uma constatação analítica retirada objetivamente do texto constitucional, de modo que não significa que a vontade do parlamentar é efetivamente geral ou que age de fato com total independência, mas que a Constituição, pelo menos de maneira inicial, na configuração do regime parlamentar, se propõe a garantir essa liberdade.

Isso torna, com efeito, o mandatário político parlamentar irresponsável diante dos destinatários do poder, no sentido de que não respondem pelo mandato para além do momento eleitoral; ${ }^{84}$ em outras palavras, a insatisfação popular com o mandatário parlamentar se resolve por regra nas eleições.

82 “Art. 45. A Câmara dos Deputados compõe-se de representantes do povo, eleitos, pelo sistema proporcional, em cada Estado, em cada Território e no Distrito Federal."

83 “Art. 46. O Senado Federal compõe-se de representantes dos Estados e do Distrito Federal, eleitos segundo o princípio majoritário."

${ }^{84}$ Por tal razão diz Prélot: "Le deputé ou le sénateur doit pouvoir exprimer et défendre sa conception propre de l'intérêt général sans redouter les conséquences personnelles de ses actes publics. Lorsqu'il parle, lorsqu'il écrit, lorsqu'il vote, il est nécessaire qu'il agisse sous les seules inspirations de la raison et de la conscience" (PRÉLOT, Marcel. Institutions politiques et droit constitutionnel, cit., p. 708). 
Outra característica inerente aos mandatos políticos parlamentares é a sua temporariedade, isto é, àquele investido em mandato representativo é estabelecido um prazo para o exercício de suas funções. O mandato parlamentar deve ser exercido dentro de um período julgado razoável e prudente politicamente pela Constituição, o que significa dizer que não deve ser extenso demais a ponto dos parlamentares esquecerem de que seu poder emana do povo, isto é, de que não detêm o poder a título "jure proprio, ao contrário, o exerce digamos por contraste - jure repraesentationis" ${ }^{\prime 85} \mathrm{e}$, com o mesmo cuidado, não deve ser curto demais a ponto de impedir o cumprimento efetivo da função. Como bem observou Maurice Duverger:

\begin{abstract}
La théorie démocratique reclame des mandats aussi brefs que possible. Il faut vérifier souvent la conformité de vues entre les électeurs et leurs élus. La pratique gouvernementale, au contraire, exige des mandats longs, qui donnent aux governants la stabilité indispensable à l'accomplissement des grandes oeuvres. ${ }^{86}$
\end{abstract}

Nessa perspectiva, Geraldo Ataliba afirma que "a excelência do sistema periódico está em assegurar a fidelidade política dos mandatários", ${ }^{87}$ fidelidade que devemos entender numa atuação em benefício do interesse do povo ou, pelo menos, na sua tendência, que se consubstancia também no respeito à Constituição e às escolhas político-ideológicas realizadas no momento eleitoral.

${ }^{85}$ SARTORI, Giovanni. A teoria da representação no Estado representativo moderno, cit., p. 46. Importante, nesse sentido, o raciocínio de John Stuart Mill, que, em 1861, ao propor aperfeiçoamentos ao modelo político inglês, assentou que um membro do Parlamento “... não deve ocupar por tanto tempo a cadeira de sorte a esquecer a responsabilidade, relaxar no cumprimento dos deveres, conduzi-los tendo em mira a própria vantagem pessoal, ou desprezar os encontros públicos e livres com os eleitores que, esteja com eles de acordo ou deles divirjam, constituem um dos benefícios do governo representativo. Por outro lado, deve contar com tal período para o exercício do cargo que permita o julguem, não por um único ato, mas pelo curso de sua atuação" (MILL, John Stuart. Considerações sobre o governo representativo. Tradução de E. Jacy Monteiro. São Paulo: Ibrasa, 1964, p. 147).

86 "A teoria democrática demanda que os mandatos tenham a duração mais breve possível. É necessário verificar continuamente a conformidade de opiniões entre os eleitores e os seus representantes eleitos. A prática do governo, pelo contrário, requer mandatos longos, que dá aos governantes a estabilidade necessária e indispensável para a realização das grandes obras." [tradução livre do autor] DUVERGER, Maurice. Cours de droit constitutionnel. Paris: Librarie du Recueil Sirey, 1946, p. 63

${ }^{87}$ ATALIBA, Geraldo. República e constituição. São Paulo: Malheiros, 2007, p. 101. Auro Augusto Caliman chama atenção para o fato de que, em um sistema parlamentarista, ao contrário do presidencialista, a relevância do mandato periódico fica relativizada "porquanto sua concepção prática pressupõem a convocação de eleições antecipadas para um novo mandato parlamentar e a formação de outro governo em virtude da dissolução do Parlamento" (CALIMAN, Auro Augusto. Mandato parlamentar: aquisição e perda antecipada, cit., p. 39). 
Nossa Constituição prevê prazo de quatro anos para cada legislatura na Câmara dos Deputados e no Senado Federal, ${ }^{88}$ aplicando-se a mesma regra para os Legislativos dos Estados, do Distrito Federal e dos Municípios. Note-se, entretanto, que, no Senado, o prazo de vigência do mandato é de oito anos, uma vez que a renovação de seus membros se dá parcialmente a cada 4 anos; assim, em uma eleição, altera-se um terço das cadeiras e, na seguinte, dois terços. ${ }^{89}$ Nessa ordem de ideias, tem-se que a legislatura no Senado é de quatro anos, enquanto os mandatos nos quais são investidos os senadores têm prazo de vigência de oito anos. ${ }^{90}$

Por fim, cabe firmar que o mandato tem a característica da irrevogabilidade, ou seja, dentro da temporariedade que lhe é inerente não é possível a ocorrência de perda do poder conferido pelo povo nas urnas, e o "eleito tem o direito de manter seu mandato durante o tempo previsto para a sua duração nas normas constitucionais" $" 91$ - somente por regra excepcional pode ser aceita a perda antecipada do mandato. O representante tem direito subjetivo ao mandato, apesar de o monopólio da candidatura eleitoral pelos partidos políticos relativizar esse direito do representante, como teremos a oportunidade de ver.

A irrevogabilidade é, de fato, uma característica irresistível, pois, se a qualquer tempo o mandato pudesse ser revogado, ainda que pelo próprio poder soberano do povo, as características da liberdade e da generalidade estariam ameaçadas, e o parlamentar teria, em tempo integral no exercício de sua função, uma vigilância que poderia lhe tolher a independência.

Privilegiando esse princípio da irrevogabilidade, a Constituição não prevê qualquer tipo de revogação do mandato antes de seu perecimento temporal ordinário, bem como não há em nosso ordenamento jurídico o instituto do recall, ou seja, a possibilidade de o mandatário

\footnotetext{
88 “Art. 44. O Poder Legislativo é exercido pelo Congresso Nacional, que se compõe de Câmara dos Deputados e do Senado Federal. Parágrafo único. Cada legislatura terá duração de quatro anos."

89 “Art. 46. [...] $\S 1^{\circ}$ Cada Estado e o Distrito Federal elegerão três Senadores, com mandato de oito anos. $\S 2^{\circ} \mathrm{A}$ representação de cada Estado e do Distrito Federal será renovada de quatro em quatro anos, alternadamente, por um e dois terços."

${ }^{90}$ A interpretação de José Afonso da Silva é a de que "A legislatura é o período que vai do início do mandato dos membros da Câmara baixa até o seu término. Isso porque a Câmara alta é contínua - ou por ser vitalícia, como era o Senado do Império brasileiro e é a Câmara dos Lordes na Grã-Bretanha, ou por ser renovável por parte, como o atual Senado brasileiro e o norte-americano" (SILVA, José Afonso da. Processo constitucional de formação das leis. São Paulo: Malheiros, 2008, p. 262).

${ }^{91}$ SILVA, José Afonso da. Poder constituinte e poder popular: estudos sobre a Constituição, cit., p. 48.
} 
parlamentar ser chamado à responsabilidade diante de seus eleitores, o que ocorre, por exemplo, nos Estados Unidos. ${ }^{92}$

Paulo Bonavides acentua, nesse sentido, que a irrevogabilidade é "por conseguinte da natureza do mandato representativo, de modo que no sistema político que o adota não há lugar para aqueles instrumentos do regime representativo semidireto, como o recall dos americanos ou o Abberufungsrecht dos suíços". 93

\subsection{Da aquisição do mandato}

As eleições configuram, inexoravelmente, a essência dos regimes constitucionais pluralistas contemporâneos, ${ }^{94}$ que, por isso, podem ser bem caracterizados como regimes de democracia representativa ou democracia eleitoral. A eleição é o mecanismo que torna factível o sistema constitucional democrático, na medida em que o princípio básico de seu modus operandi, a manifestação individual e juridicamente igual de cada membro da sociedade estatal na escolha de mandatários políticos, dá o sentido de um governo por consentimento na mesma linha teórica lockiana de um poder escolhido, nomeado pelo público $^{95} \mathrm{e}$, portanto, legítimo. O consenso democrático reside essencialmente no consentimento eleitoral. $^{96}$

\footnotetext{
${ }^{92}$ Sobre o recall, Walter Costa Porto assevera que: "Já se afirmou, muitas vezes, que o recall teve origem em Los Angeles, em 1903. Mas ele foi pela primeira vez enunciado nos EUA, nos artigos da Confederação, que reservaram aos Estados o direito de destituir seus delegados ao Congresso e enviar outros em seu lugar" (PORTO, Walter Costa. Dicionário do voto, cit., p. 275). Importante trazer nesse passo também a observação de Auro Augusto Caliman: "A possibilidade de cassação do mandato parlamentar pelos eleitores foi ignorada por todas as Constituições do Brasil; não, porém, pelas Constituições Estaduais. Decorrente da autonomia conferida aos Estados-membros pelo princípio federativo que acabara de ser adotado, as primeiras Constituições Estaduais goiana, paulista, rio-grandense-do-sul e catarinense traziam um peculiar mecanismo de perda individual do mandato parlamentar, o recall" (CALIMAN, Auro Augusto. O recall no Estado de São Paulo. Brasília: Revista de Informação Legislativa, 2005, p. 199).

${ }^{93}$ BONAVIDES, Paulo. Ciência política, cit., p. 262. O abberufungsrecht consiste na revogação do mandato de toda a Assembleia no caso de um número determinado de cidadãos requerer que a questão seja posta em votação popular, o que configura direito de dissolução do Parlamento que cabe ao próprio povo (PORTO, Walter Costa. Dicionário do voto, cit., p. 275).

${ }^{94}$ FARIA, José Eduardo. Poder e legitimidade. São Paulo: Perspectiva, 1978, p. 63. Para uma análise críticoteórica da centralidade eleitoral na definição da legitimidade democrática, ver: SCHMITT, Carl. Teoria de la constitución, cit., p. 106-107 e 238-240.

${ }^{95}$ LOCKE, John. Dois tratados sobre o governo. São Paulo: Martins Fontes, 1998, p. 503.

${ }^{96}$ Tomamos aqui a questão eleitoral enquanto conteúdo da legitimidade em um alto grau de generalidade, por óbvio os sistemas eleitorais concretamente delineados em cada ordenamento jurídico estatal trazem seus próprios caracteres e especificidades. Como assenta Hamon, Troper e Burdeau: “... no espírito democrático, um único
} 
Importante nesse aspecto a lição de Monica Herman Salem Caggiano, para quem a eleição é "um dos caracteres de maior peso da definição do modelo democrático, que repousa sobre bases preordenadas ao atendimento da exigência por eleições livres e amplamente competitivas para a seleção de representantes". 97

A junção representação e eleição foi também abordada por José Afonso da Silva, ao salientar que:

A eleição consubstancia o princípio da representação, que se efetiva pelo mandato político representativo, que constitui situação jurídica-política com base na qual alguém, designado por via eleitoral, desempenha uma função política governamental na democracia representativa. ${ }^{98}$

Dessarte, temos que a eleição é o instrumento que dá efetividade à representação, ${ }^{99}$ ao justificar e dar embasamento ao mandato representativo, de modo que é tão somente por tal procedimento que se pode ter acesso ao nível político estatal como representante legitimado a tomar decisões em nome do povo. É a dinâmica eleitoral que estabelece o ponto de contato entre Estado e sociedade na era contemporânea.

Dando guarida formal a essa perspectiva, a Constituição de 1988 prevê em seu art. 14 que a soberania popular será exercida pelo sufrágio universal e pelo voto direto e secreto, com valor igual para todos. Assim, o sufrágio configura-se como um direito público fundamental de caráter subjetivo, ${ }^{100}$ e a sua importância, enquanto alicerce central de nosso sistema constitucional, vem confirmada no art. 60, II, que blinda o voto direto, secreto, universal e periódico de qualquer possibilidade de modificação tendente à sua abolição.

$\mathrm{O}$ acesso ao mandato parlamentar por via eleitoral tem certas especificidades conforme diga respeito à Câmara dos Deputados, ao Senado Federal, às Assembleias Legislativas ou às

procedimento é aceitável, é a eleição. Mas a eleição em si mesma é suscetível de modalidades bem diferentes que influem no resultado do escrutínio e, por conseguinte, na importância do voto emitido pelos cidadãos" (HAMON, Francis; TROPER, Michel; BURDEAU, Georges. Direito constitucional, cit., p. 152). Assim, a legitimidade democrática deve ser sempre analisada sob o solo de cada Estado, naquilo que se tornou aceitável, no que se institucionalizou: "No existe una legitimidad, sino unas legitimidades, según los grupos sociales, los países, las épocas, etcétera” (DUVERGER, Maurice. Metodos de las ciências sociales. Barcelona: Ariel, 1980, p. 523).

${ }^{97}$ CAGGIANO, Monica Herman Salem. Eleições 2002: o financiamento das campanhas eleitorais e seu controle. Enquadramento jurídico. São Paulo: Revista de Direito Mackenzie, ano 1, n. 1, jan./jun. 2000, p. 89.

${ }^{98}$ SILVA, José Afonso da. Poder constituinte e poder popular: estudos sobre a Constituição, cit., p. 48.

${ }^{99}$ ATALIBA, Geraldo. República e constituição, cit., p. 13.

${ }^{100}$ MENDES, Antonio Carlos. Introdução à teoria das inelegibilidades, cit., 1994. p. 74. Nessa linha, diz Sartori: "En los sistemas proporcionales, el triunfo es compartido y sencillamente se requiere un porcentaje electoral (por lo general, el cociente electoral)" (SARTORI, Giovanni. Ingeniería constitucional comparada. México: Fondo de Cultura Económica, 2005). 
Câmaras Municipais. Verifique-se, por exemplo, que, de acordo com o nosso Texto Político, os deputados federais são eleitos pelo sistema proporcional que "assegura aos diferentes partidos no Parlamento uma representação correspondente à força numérica de cada um"101 (art. 45 da Constituição Federal), enquanto os senadores são eleitos segundo o princípio majoritário, isto é, saem vitoriosos no pleito os candidatos com a maior votação, sem qualquer necessidade de constatação da proporcionalidade de votos recebido para a aferição das cadeiras a que tem direito cada partido ${ }^{102}$ (art. 46 da Constituição Federal).

Aquele que vislumbra fazer parte do corpo Legislativo do Estado em qualquer de suas instâncias, municipal, estadual, distrital ou federal, deve estar atento às regras eleitorais, ${ }^{103}$ tanto as previstas na Constituição como as infraconstitucionais, que ditam o caminho para aquele que tem o interesse em ascender ao nível político na instituição Parlamentar.

Com efeito, a aquisição do mandato por meio de eleições importa, a princípio, em ser considerado juridicamente capaz de ser eleito, de receber de forma válida os votos emitidos pelo cidadão eleitor no exercício da soberania popular e estar apto a ser investido em um mandato como representante político. Em síntese, é preciso ter capacidade eleitoral passiva para que seja possível alcançar a situação de mandatário parlamentar. Esclareça-se, nesse passo, que o direito político acaba por revelar duas facetas no plano de seu exercício, uma passiva e outra ativa, que correspondem, respectivamente, ao "direito de votar (ius suffagii) e

${ }^{101}$ FERREIRA, Pinto. Código eleitoral comentado. São Paulo: Saraiva, 1998, p. 144-145.

${ }^{102}$ Nas explicações de Djalma Pinto temos que o sistema majoritário diz respeito a duas modalidades: "Na primeira, é considerado eleito quem pura e simplesmente obtém maior número de votos entre os candidatos participantes do certame. Diz-se, nesse caso, sistema majoritário simples ou de um único turno. Verifica-se, por exemplo, na eleição para o Senado. Basta maioria simples ou relativa para o candidato ser aclamado vencedor. Na segunda modalidade, sistema de dois turnos, é considerado vencedor o candidato que obtenha, no primeiro turno de votação, a maioria absoluta dos votos, não computados os brancos e os nulos, ocorrendo nova eleição se nenhum deles atingir esse percentual. No Brasil, caso nenhum dos postulantes consiga atingir esse percentual, realiza-se um segundo turno de votação, dele participando apenas os dois candidatos mais votados, sagrando-se vencedor o que obtiver maior votação" (PINTO, Djalma. Direito eleitoral: improbidade administrativa e responsabilidade fiscal. São Paulo: Atlas, 2007, p. 172).

${ }^{103}$ Adverte Monica Herman Salem Caggiano que “... o processo eleitoral, de índole complexa por tendência própria, espalha seu domínio para alcançar todo o espectro eleitoral, contagiando a própria legislação, que neste ambiente se apresenta esparsa, sinuosa e afeta a constantes flutuações, sempre submissas à influência dos interesses do grupo detentor do poder político" (Direito parlamentar e direito eleitoral, cit., p. 86). Essa referida sinuosidade se demonstra pela amplitude de regramentos normativos atinentes ao fenômeno eleitoral no Brasil: Lei n. 9.504, de 30 de setembro de 1997; Lei n. 4.737, de 15 de julho de 1965 (Código Eleitoral); Lei n. 9.096, de 19 de setembro de 1995 (Partidos Políticos); Lei Complementar n. 64, de 18 de maio de 1990 (Inelegibilidades); além das muitas resoluções baixadas pelo Tribunal Superior Eleitoral com instruções para a fiel execução da legislação eleitoral (Código Eleitoral, art. 23, IX; Lei n. 9.096/95, art. 61; e Lei n. 9.504/97, art. 105). 
ao direito de ser votado, de disputar cargos públicos (ius honorum), dois aspectos da capacidade política do cidadão". ${ }^{104}$

Buscando regrar essa questão, nossa Constituição estabelece algumas condições de elegibilidade em seu art. $14, \S 3^{\circ}$, quais sejam, (I) a nacionalidade brasileira, (II) o pleno direito dos direitos políticos, (III) o alistamento eleitoral, (IV) o domicílio eleitoral na circunscrição, (V) a filiação partidária e (VI) idade mínima de: (a) trinta e cinco anos para Presidente e Vice-Presidente da República e Senador; (b) trinta anos para Governador e ViceGovernador; (c) vinte um anos para Deputado Federal, Deputado Estadual ou Distrital, Prefeito, Vice-Prefeito e juiz de paz; e (d) dezoito anos para Vereador.

Atente-se para o fato de que é obrigatória a filiação em partido político para que se possa competir nas eleições, ou seja, a Constituição, como regra geral, não permite a candidatura avulsa. Diante desse cenário, pode-se dizer que, no quadro de nossa sistemática constitucional, a candidatura é monopólio do partido político, sendo, por isso, "assegurado a todos o direito de livre acesso aos partidos, sem possibilidade de existência de requisitos discriminatórios ou arbitrários". ${ }^{105}$ Essa partidarização do momento eleitoral gera uma vinculação inevitável entre representante e partido, o que, por certo, modifica a própria ideia de "mandato livre", conforme concebemos anteriormente, quando da abordagem das características que marcam o mandato representativo. Esse aspecto leva Manoel Gonçalves Ferreira Filho a alertar que:

104 CAGGIANO, Monica Herman Salem. Direito parlamentar e direito eleitoral, cit., p. 86. Essas duas dimensões são determinadas a partir da ideia de voto a ser emitido e voto a ser recebido correlacionada ao reconhecimento constitucional; no plano político, pode-se aventar uma tipologia semelhante, mas abarcando a ideia de atuação ativa e passiva em termos de busca do domínio político - é o que faz, por exemplo, Weber: “... a empresa política se põe, necessariamente, como empresa de interesses. Quer isso dizer que um número relativamente restrito de homens interessados pela vida política e desejosos de participar do poder aliciam seguidores, apresentam-se como candidato ou apresentam a candidatura de protegidos seus, reúnem os meios financeiros necessários e se põem à caça de sufrágios. Sem essa organização, não há como estruturar praticamente as eleições em grupos políticos amplos. Equivalem essas palavras a afirmar que, na prática, os cidadãos com direito a voto dividem-se em elementos politicamente ativos e em elementos politicamente passivos. [...] A existência de chefes e seguidores que, enquanto elementos ativos, buscam recrutar, livremente, militantes e, por outro lado, a existência de um corpo eleitoral passivo constituem condições indispensáveis à existência de qualquer partido" (WEBER, Max. Ciência e política: duas vocações, cit., p. 84).

${ }^{105}$ MORAES, Alexandre de. Constituição do Brasil interpretada e legislação constitucional. São Paulo: Atlas, 2002, p. 543. Importante lembrar que a Lei n. 9.096/95, a qual dispõe sobre os partidos políticos, considera seu art. 16 como requisito para a filiação partidária o pleno gozo dos direitos políticos. Ademais, não podemos nos esquecer também de que há previsão de vedações à atividade político-partidária para Membros da Defensoria Pública (arts. 46, V; 91, V; e 130, V, da Lei Complementar n. 80/94), Membros do TCU (art. 73, §§ $3^{\circ}$ e $4^{\circ}$, da Constituição Federal); Membros da Magistratura (art. 95, parágrafo único, III, da Constituição Federal); Membros do Ministério Público, (art. 128, § 5 , II, e); Militares no período de serviço ativo (art. 142, § $3^{\circ}$, V); e para funcionários da Justiça Eleitoral (art. 366 do Código Eleitoral). 
O representante, antes de representar o povo, representa o partido. Torna-se ele, com efeito, dependente das instâncias deste. Sua candidatura depende dos órgãos partidários, sua eleição do apoio deste e a apreciação de sua conduta pelo comando do partido determinará o seu futuro. [...] Esta vinculação estreita entre o eleito e o partido revoluciona o chamado mandato representativo (mandato "livre") e se aproxima do mandato imperativo, típico do modelo medieval de representação, que ainda é expressamente repelido por várias Constituições em vigor... ${ }^{106}$

Ao lado das condições de elegibilidade, que consistem na capacidade do cidadão de receber votos dos eleitores, prevê nosso Texto Maior hipóteses de inelegibilidade, circunstâncias que impedem objetivamente o cidadão de receber votos para determinado cargo público eletivo, por exemplo, no caso dos inalistáveis ${ }^{107}$ e dos analfabetos (art. $14, \S 4^{\text {o }}$, da Constituição Federal). Com isso, para estar apto à competição eleitoral, é necessário preencher as condições de elegibilidade e também não estar enquadrado em nenhum dos impedimentos constantes do art. $14, \S \S 4^{\circ}$ ao $\S 9^{\circ}$, da Constituição.

De fato, o efeito geral tanto no caso do não preenchimento das condições de elegibilidade como no caso da ocorrência do impedimento da inelegibilidade é o mesmo, qual seja, a inaptidão jurídica para competir, receber votos e ser eleito. Por tal motivo, Sérgio Sérvulo da Cunha chama as condições de elegibilidade inscritas no art. $14, \S 3^{\circ}$, da Constituição de "inelegibilidades impróprias", ${ }^{108}$ isto é, uma vez não preenchidos os requisitos, ocorre o impedimento à eleição.

Convém frisar, todavia, que regras sobre inelegibilidades no âmbito dos Estados democráticos contemporâneos devem ter um caráter excepcional, isso porque o direito político à competição eleitoral (elegibilidade) tem status de liberdade pública fundamental. ${ }^{109} \mathrm{~A}$ Constituição de 1988 sinaliza nesse caminho, ao albergar o Capítulo dos Direitos Políticos

${ }^{106}$ FERREIRA FILHO, Manoel Gonçalves. Princípios fundamentais do direito constitucional, cit., p. 66-67.

107 Art. 14, § 2 : "Não podem alistar-se como eleitores os estrangeiros e, durante o serviço militar obrigatório, os conscritos". Devemos considerar enquadrado nessa classificação de inalistáveis os menores de 16 anos, já que o art. $14, \S 1^{\circ}$, I e II, impõe esse limite, ao ditar que o alistamento eleitoral são obrigatórios para os maiores de dezoito anos e facultativo para os maiores de dezesseis anos e menores de dezoito. Por fim, nessa categoria, devese considerar os que tiverem privado temporária ou definitivamente de seus direitos políticos. Ver, a esse respeito, SILVA, José Afonso da. Comentário contextual à Constituição, cit., p. 232 e AMARAL, Roberto; Cunha, Sérgio Sérvulo da. Manual das eleições. São Paulo: Saraiva, 2006, p. 121.

${ }^{108}$ CUNHA, Sérgio Sérvulo da. Fundamentos de direito constitucional. São Paulo: Saraiva, 2008. v. 2, p. 483.

${ }^{109}$ CAGGIANO, Monica Herman Salem. Direito parlamentar e direito eleitoral, cit., p. 86. 
dentro de seu Título II, que trata especificamente dos Direitos e Garantias Fundamentais. A consolidação das instituições democráticas evidencia também tal circunstância - a esse respeito, lembremos a Declaração Universal dos Direitos Humanos, de 10 de dezembro de 1948, a qual, em seu art. 21, dispõe que "Toda pessoa tem o direito de tomar parte no governo de seu país, diretamente ou por intermédio de representantes livremente escolhidos”. É o que estabelece também o Pacto Internacional dos Direitos Civis e Políticos de 16 de dezembro de 1966, consoante seu art. 25:

Todo cidadão terá o direito e a possibilidade, sem qualquer das formas de discriminação [...] e sem restrições infundadas: de participar da condução dos assuntos públicos, diretamente ou por meio de representantes livremente escolhidos; de votar e ser eleito em eleições periódicas, autênticas, realizadas por sufrágio universal e igualitário e por voto secreto, que garantam a manifestação da vontade dos eleitores; de ter acesso, em condições gerais de igualdade, às funções públicas de seu país.

Preenchidos os requisitos necessários à candidatura e não havendo qualquer impedimento, tem-se posta a disputa legítima por meio da campanha eleitoral que terá sua lisura e legalidade controlada pela Justiça Eleitoral, ${ }^{110}$ a qual é o órgão competente para preparar e organizar o "alistamento eleitoral, as eleições, a apuração dos votos, a diplomação dos eleitos, julgar os crimes eleitorais, as ações objetivando a cassação do registro, do diploma ou do mandato dos candidatos eleitos ou a declaração de inelegibilidade". 111

O direito subjetivo do eleito, inclusive do suplente, ao exercício do mandato parlamentar se dá pela expedição de diploma pela Justiça Eleitoral, ${ }^{112}$ que lhe atribui uma

${ }^{110}$ Quanto às origens da Justiça Eleitoral, Pinto Ferreira relata que "teve sua origem histórica na Inglaterra, com Disraeli, em 1896. Desconheceu-a o Brasil e o Império e a Primeira República. Entre nós foi criada como consequência da Revolução de 1930, de vigorosa impulsão e infeliz malogro, logo sufocada pelo regime autoritário subsequente" (FERREIRA, Pinto. Código eleitoral comentado, cit., p. 44). Atualmente, a Justiça Eleitoral é composta pelos seguintes órgãos: I - o Tribunal Superior Eleitoral; II - os Tribunais Regionais Eleitorais; III - os Juízes Eleitorais; IV - As Juntas Eleitorais (art. 118 da Constituição Federal).

${ }^{111}$ PINTO, Djalma. Direito eleitoral: improbidade administrativa e responsabilidade fiscal, cit., p. 37.

${ }^{112}$ Código Eleitoral: “Art. 30. Compete, ainda, privativamente, aos Tribunais Regionais: [...] VII - apurar com os resultados parciais enviados pelas juntas eleitorais, os resultados finais das eleições de Governador e ViceGovernador de membros do Congresso Nacional e expedir os respectivos diplomas, remetendo dentro do prazo de 10 (dez) dias após a diplomação, ao Tribunal Superior, cópia das atas de seus trabalhos; [...] Art. 215. Os candidatos eleitos, assim como os suplentes, receberão diploma assinado pelo Presidente do Tribunal Superior, do Tribunal Regional ou da Junta Eleitoral, conforme o caso. Parágrafo único. Do diploma deverá constar o nome do candidato, a indicação da legenda sob a qual concorreu, o cargo para o qual foi eleito ou a sua classificação como suplente, e, facultativamente, outros dados a critério do juiz ou do Tribunal". 
cadeira partidária na esfera do Legislativo. Convém, nessa perspectiva, transcrever as lúcidas palavras de José Cretella Júnior:

... o diploma é para o congressista o que o título de nomeação é para o agente público. A partir da expedição do diploma estabelece-se o vinculum iuris entre mandantes e mandatário, ao mesmo tempo em que se firma o regime jurídico do Deputado ou Senador com o Congresso, garantindo-lhes direitos e impondo-lhe deveres. ${ }^{113}$

A investidura no mandato parlamentar se dá efetivamente com ato de posse, ato público a partir do qual o diplomado passa a exercer o mandato. Compete a cada uma das Casas do Congresso Nacional se reunir no dia $1^{\circ}$ de fevereiro, no primeiro ano da nova legislatura, para dar posse aos novos membros. ${ }^{114}$

1.3 Da perda do mandato

Exploradas as características inerentes aos mandatos políticos parlamentares e determinada a forma como se dá a sua aquisição, resta observar o fenômeno de sua perda.

Afiança Geraldo Ataliba que “... os mandatos vêm sempre assinalados por duas características essenciais: a periodicidade e a responsabilidade". ${ }^{115}$ Ambas as características estão interligadas na medida em que é no fim do período de mandato que ocorre a responsabilização realizada pelo eleitorado, que dependendo da situação pode negar uma reeleição, retirando do espectro do poder estatal determinado partido ou programa político partidário indesejado. Com efeito, o mandato político parlamentar está matizado pela ideia de alternância no poder, de possibilidade de substituição dos detentores do poder por outros conforme livre escolha popular.

113 JÚNIOR, José Cretella. Comentários à Constituição brasileira de 1988. São Paulo: Forense Universitária, 1992. v. V, p. 2.626. Nessa perspectiva, Pinto Ferreira diz que "a expedição do diploma pela Justiça Eleitoral caracteriza a eleição: antes dela havia somente o candidato; após, há o eleito" (FERREIRA, Pinto. Comentários à Constituição brasileira. São Paulo: Saraiva, 1992. v. 3, p. 02). Ver também FERREIRA FILHO, Manoel Gonçalves. Comentários à Constituição brasileira de 1988. São Paulo: Saraiva, 1992. v. 2, p. 52.

114 “Art. 57. O Congresso Nacional reunir-se-á, anualmente, na Capital Federal, de 2 de fevereiro a 17 de julho e de $1^{\circ}$ de agosto a 22 de dezembro. [...] $\S 4^{\circ}$ Cada uma das Casas reunir-se-á em sessões preparatórias, a partir de $1^{\circ}$ de fevereiro, no primeiro ano da legislatura, para a posse de seus membros e eleição das respectivas Mesas, para mandato de 2 (dois) anos, vedada a recondução para o mesmo cargo na eleição imediatamente subsequente." ${ }^{115}$ ATALIBA, Geraldo. República e constituição, cit., p. 51. 
Resulta dessa análise que é da natureza do mandato representativo o seu perecimento pelo decurso de prazo. Essa constatação, que em princípio parece tão óbvia, está fundada na ideia democrática de que todos são iguais perante a lei. Não por outro motivo a periodicidade dos mandatos é cláusula pétrea constitucional (art. 60, § $4^{\circ}$, II, da Constituição Federal) e, além disso, é da dinâmica do Estado contemporâneo a mudança do corpo de indivíduos que exercem o poder estatal de modo a propiciar a todos, formalmente, a oportunidade de participação na direção da sociedade a partir do aparato estatal. ${ }^{116}$ Não ocorre, nesse contexto, a cristalização de uma "casta" patrimonialista na estrutura estatal, situação que fora vivenciada de diversas formas no período do Estado absoluto, no qual o princípio monárquico fundado na hereditariedade e na pessoalidade divina do poder impedia o desenvolvimento efetivo da ideia democrática, de uma soberania popular ou mesmo da nação.

Conforme verificamos no tópico precedente, o momento inicial do mandato parlamentar se dá após o término do processo eleitoral. É a partir da expedição do diploma que se inicia o vínculo jurídico político do mandato representativo, que garante ao eleito o exercício do mandato (posse) até seu término (temporariedade).

Esse término ordinário do mandato, isto é, depois de ultrapassado o quadrante temporal previsto pela Constituição para o seu exercício, se dá coletivamente, podendo abarcar a integralidade da Casa legislativa - como é o caso da Câmara dos Deputados, a qual renova por inteiro suas $513^{117}$ cadeiras em cada eleição - ou ser de modo parcial - por exemplo, o Senado Federal, que tem seu quadro de 81 senadores renovado a cada quatro anos, alternadamente, por um e dois terços (art. 46, $\S 2^{\circ}$, da Constituição Federal). ${ }^{118}$

116 É muito interessante que na França, tendo em vista a própria dinâmica histórico-política daquele país, o regime democrático que pregava a igualdade de todos perante a lei acabasse por colocar na Constituição uma vedação absoluta de elegibilidade aos familiares dos reis, ou seja, contra o princípio da hereditariedade no poder foi imposta a impossibilidade hereditária de acesso ao poder a certos indivíduos, o que resulta em uma contradição ao próprio princípio da igualdade, mas que encontra sua razoabilidade na história política francesa. Duguit afirma sobre o assunto: "Inélegibilités absolutes. - Elles frappent les catégories de personnes suivantes: $1^{\circ}$ Les membres des familles qui ont régné sur la France sont inélegibles au sénat et à la chambre des deputés (L. 9 décembre 1884 , art. $4^{\circ}, \S 2^{\circ}$, pour le sénat; L. 16 juin 1885 , art. $4^{\circ}$, pour la chambre des deputés). La loi du 22 juin 1886, relative aux membres des familles ayant régné en France, contient une prohibicion générale: "Les membres des familles ayant régné en France ne pourront entrer dans les armées de terre et de mer, ni exercer aucune fonction publique, ni aucun mandat électif' (art. $4^{\circ}$ ). On voit facilement quelles raisons ont amené le gouvernement républicain à provoquer le vote de ces dispositions législatives" (DUGUIT, Leon. Traité de droit constitutionnel. Paris: Ancienne Librairie Fontemoing \& Cie, Éditeurs, 1924, p.163-164).

${ }_{117}$ Número firmado pela Lei Complementar n. 78, de 30 de dezembro de 1993, que disciplina a fixação do número de deputados, nos termos do art. $45, \S 1^{\circ}$, da Constituição Federal.

118 Dependendo do ordenamento constitucional particular adotado em cada país, encontramos contornos distintos para o término ordinário do mandato parlamentar; nesse aspecto, por exemplo, podemos trazer as análises de 
Nesse ponto, a questão que se coloca no âmbito de nosso trabalho envolve descortinar as causas constitucionais aptas a impedir que o mandato siga seu curso até o fim ordinário e, dentro do desenvolvimento dessas causas, encontrar o lugar da cassação por quebra de decoro.

A ocorrência da perda do mandato parlamentar antes do fim ordinário colimado na Lei Maior deve ser encarada sempre como uma anormalidade ou excepcionalidade pelo simples fato de que implica uma situação de impacto ao regime democrático, pois, nessa circunstância, ocorre o desfazimento da relação de representação política. Quanto a esse aspecto, é importante lembrar que a representação política não encerra apenas um direito subjetivo do mandatário ou do partido político mas também consubstancia um direito à representação legítima por parte do cidadão eleitor, melhor dizendo, trata-se de respeitar a decisão soberana das urnas.

Desta feita, observa-se na Constituição de 1988 hipóteses de perda antecipada de mandato, todas dizendo respeito a perdas individuais do status político de representante. Dentre essas hipóteses explícitas é que encontramos a perda de mandato por ofensa ao decoro.

$\mathrm{O}$ art. 55 da Constituição dita que perderá o mandato o deputado ou senador: I - que infringir quaisquer das normas de incompatibilidades previstas no art. 54; II - cujo procedimento for declarado incompatível com o decoro parlamentar; III - que deixar de comparecer, em cada sessão legislativa, à terça parte das sessões ordinárias da Casa a que pertencer, salvo licença ou missão por esta autorizada; IV - perder ou tiver suspensos os direitos políticos; V - quando decretar a Justiça Eleitoral, nos casos previstos na Constituição; e VI - que sofrer condenação criminal em sentença transitada em julgado.

Note-se que a ordem emanada do texto constitucional dispõe que perca o mandato aquele que se enquadrar em quaisquer das situações estabelecidas nos incisos do art. 55, não fazendo inicialmente qualquer distinção jurídica entre elas. Entretanto, devemos observar que as hipóteses inseridas nos referidos incisos abrangem duas espécies diferentes de perda de

Prélot "La fin collective du mandat. - A l'Assemblée nationale, le renouvellement est integral. Tous les mandats, qu'ils soient détenus par le titulaire initial ou par son remplaçant, s'achèvent en même temps: $1^{\circ}$ soit à la date d'expiration normale des pouvoirs. [...] $2^{\circ}$ soit à une date différent fixée par la loi. [...] $3^{\circ}$ soit à la suíte d'une dissolution. $4^{\circ}$ soit à la date de la cessation de la souveraineté française. [...] Au Sénat, le regime est celui du renouvellement partiel. Les sénateurs sont repartis en trois séries déterminées par l'ordre alphabétique du département dans lequel ils sont élus" (PRÉLOT, Marcel. Institutions politiques et droit constitutionnel, cit., p. 717-718). 
mandato que devem ser bem ressaltadas. De um lado, há o fenômeno da cassação ${ }^{119}$ de mandato, enquanto de outro existe a mera extinção do direito ao seu exercício. ${ }^{120}$

Essa distinção está posta, em primeiro lugar, pelo $\S 2^{\circ}$ do art. 55 , o qual determina que, nos casos previstos nos incisos I, II e V, a decretação da perda do mandato se dê por decisão da respectiva Casa legislativa a que pertencer o parlamentar. Com efeito, nesses casos, para que seja decretada a perda do mandato, os membros da Câmara dos Deputados ou do Senado Federal devem analisar a situação, criar a sua convicção e deliberar por voto secreto e maioria absoluta. ${ }^{121}$ Isso implica, do ponto de vista jurídico, uma decisão de natureza constitutiva que cria uma situação nova não constatável antes do próprio julgamento da Casa parlamentar. Em outras palavras, diz respeito a uma decisão punitiva, tendo em vista uma violação de deveres constitucionais que será valorada pelos pares.

Já no que concerne ao exposto nos incisos III, IV e V do art. 55, não há apreciação e decisão por parte da Casa legislativa sobre a ocorrência ou não da hipótese ou sobre a necessidade ou não de ser decretada a perda do mandato, mas, sim, a constatação de uma situação jurídica anteriormente existente e insuperável, qual seja, a do perecimento do mandato. ${ }^{122}$ A decisão, nessas hipóteses, tem natureza declaratória.

Essa interpretação encontra fundamento no texto constitucional, vê-se no art. 55, § $3^{\circ}$, segundo o qual, nos casos previstos nos incisos III e V, a perda será declarada pela Mesa da Casa respectiva, de ofício ou mediante provocação de qualquer um de seus membros ou de partido político representado no Congresso Nacional, assegurada ampla defesa. Embora o $\S 3^{\circ}$ não elenque o inciso IV, o qual prevê a hipótese de perda de mandato a aquele membro do parlamento que perder ou tiver suspensos os direitos políticos, devemos entender inserido em seu âmbito o referido inciso, como bem aponta José Afonso da Silva:

A Constituição não disse como se define a perda de mandato no caso em que o congressista perde ou tem suspensos seus direitos políticos, mas, à evidência, nesse caso se dá a extinção do

\footnotetext{
119 O termo pode parecer inapropriado, já que, no art. 15 da Constituição, ele aparece com uma conotação negativa, como um ato arbitrário emitido em desconformidade com os preceitos constitucionais.

${ }^{120}$ FERREIRA, Pinto. Comentários à Constituição brasileira, cit., p. 24.

${ }^{121}$ JÚNIOR, Dirley da Cunha. Curso de direito constitucional. Bahia: Podium, 2010, p. 1.023.

${ }^{122}$ SILVA, José Afonso da. Curso de direito constitucional. São Paulo: Malheiros, 2010, p. 537.
} 
mandato como consequência direta daquele fato; não há nada a fazer senão a própria Mesa da Casa do congressista reconhecer, por declaração, a perda do mandato. ${ }^{123}$

${ }^{123}$ SILVA, José Afonso da. Comentário contextual à Constituição, cit., p. 429. 


\section{CAPÍTULO 2 - DO CONCEITO DE DECORO PARLAMENTAR: FONTES}

A perda antecipada do mandato realizada por meio da cassação por quebra de decoro nos termos do art. 55, II, da Constituição, impõe de antemão uma identificação mínima do que podemos compreender por decoro, mais especificamente, obriga-nos a indicar os elementos teóricos jurídicos e políticos que tornam possível afirmar, conforme determinada situação, se estamos diante de um ato ofensivo ao decoro parlamentar. Embora, como já tivemos oportunidade de constatar, cada Casa legislativa tenha competência para decidir sobre a perda do mandato de seus respectivos pares, esse poder de decisão não significa poder de interpretar as circunstâncias políticas de modo completamente livre, sem qualquer parâmetro, conferindo ao conceito de decoro o conteúdo que bem entender.

Verifica-se, portanto, que os parâmetros que possibilitam dizer se uma conduta específica é ou não ofensiva ao decoro não advêm dos desejos parlamentares e não estão fundados somente nas regras de luta política na esfera do Legislativo. Maiorias parlamentares não estão autorizadas a usar o instrumento previsto no art. 55, II, da Constituição Federal como um meio de retirar da esfera institucional do Legislativo agentes políticos indesejados, tendo em vista suas posições políticas legítimas.

De fato, o jogo político institucional exige certa margem de razoabilidade, a qual é imposta pela Constituição; assim, dizer que a decisão que cassa o mandato parlamentar é uma decisão política não significa afirmar que ela possa ser arbitrária, mas, sim, que ela está, antes de tudo, limitada por ditames constitucionais e infraconstitucionais. A Casa legislativa, quando impõe a perda de mandato a um de seus membros, está a exercer uma competência constitucional, ou melhor, uma competência dada pela Constituição, e por isso mesmo posta como um poder a ser exercido em razão do dever de garantia da dignidade e prestígio institucional do Parlamento - para além disso há apenas abuso e desconfiguração do instituto.

Nesse ponto, o primeiro aspecto que devemos notar quando procuramos determinar um conteúdo mínimo para o conceito de decoro é o de que, ao falar em procedimento indecoroso ou decoro parlamentar, lidamos com aquilo que a doutrina do direito costuma chamar de conceito jurídico fluído, impreciso ou indeterminado. Afinal, quem seria capaz, apenas constatando os dizeres do art. 55, II, da Constituição Federal - que estabelece a cassação para aquele "cujo o procedimento for declarado incompatível com o decoro parlamentar" -, de 
aduzir um rol taxativo ou regras claras e determinantes do que seja decoro? Por essa razão, José Afonso da Silva afirma que "nem é necessário rebuscar doutrinas na procura de conceito preciso de "decoro parlamentar". Esse é um daqueles conceitos abertos". ${ }^{124}$ Corroborando essa percepção, Sepúlveda Pertence, ex-Ministro do Supremo Tribunal Federal, pode, em julgado daquela Corte, com acentuada lucidez, reconhecer que: "Desconheço, a esse propósito, em outras ordens positivas, locução de termos tão imprecisos quanto essa, a do 'decoro parlamentar', cujas conotações vão da sublimidade da Ética às Frivolidades da Etiqueta". ${ }^{125}$

Dessarte, não é possível, a priori, estabelecer de forma inequívoca o que seja uma conduta indecorosa, estando, assim, aberto ao julgamento da Câmara e do Senado decidir se determinado procedimento concreto ofende ou não a dignidade e a honorabilidade da função parlamentar. Como veremos, parece prudente que assim o seja, tendo em vista a finalidade da norma, que é proteger a legitimidade democrática do Parlamento a partir da garantia da moralidade institucional.

Nesse passo, somos obrigados a concluir que a hipótese da conduta indecorosa como pressuposto e motivo determinante para a sanção política da perda de mandato diz respeito a um conceito de natureza sócio-histórica, implicando sempre uma análise conforme o tempo (relativa). Com efeito, se o ordenamento jurídico pretende apreender o conteúdo do decoro como um requisito legal do comportamento dos agentes políticos parlamentares, impende que o faça de modo a abarcar as mudanças temporais pelas quais o conceito passa no âmbito da sociedade. Tal sentido é captado por Carla Costa Teixeira, ao afirmar que "o decoro parlamentar, como um código de honra, precisa se referir aos valores de uma época e de um grupo. Daí a sua necessária imprecisão, sua natureza avessa à plena tradução em atos especificados juridicamente". ${ }^{126}$

Com abordagem similar, assevera Cármen Lúcia Antunes Rocha que "há que se observar, todavia, que a concepção hodierna de Moral não se elabora com o entendimento de ser esta lei eterna, natural e impessoal, mas com a inteligência de que ela é o que o povo assenta e respeita em dado momento de sua história". ${ }^{127}$

\footnotetext{
${ }^{124}$ SILVA, José Afonso da. Comentário contextual à Constituição. Malheiros: São Paulo, 2006, p. 424.

${ }^{125}$ Supremo Tribunal Federal, MS 25.579/DF, Rel. Min. Sepúlveda Pertence, DJU de 24/08/2007.

${ }^{126}$ TEIXEIRA, Carla Costa. A honra da política. Rio de Janeiro: Relume Dumará, 1998, p. 70.

${ }^{127}$ ROCHA, Cármen Lúcia Antunes. Princípios constitucionais da administração pública. Belo Horizonte: Del Rey, 1994, p. 182.
} 
Dessa forma, observamos que, em certas épocas, determinada conduta parlamentar pode ser aceita como não ofensiva à moralidade institucional e em outras não. Nada mais plausível do que garantir um nível de imprecisão normativa quando da previsão de institutos de defesa da moralidade institucional, como é o caso da cassação de mandato por quebra de decoro. Se houvesse previsão tipificada e rígida do que seria um procedimento indecoroso, com o tempo o Parlamento poderia encontrar-se de mãos atadas diante de condutas parlamentares que ofendessem a moralidade institucional, mas que não se enquadrassem na tipificação normativa adotada.

Nessa esteira, vem a calhar a análise realizada por John B. Thompson, embora tratando especificamente do fenômeno da corrupção:

\footnotetext{
Mas o grau de censura moral associado a determinadas formas e casos de corrupção irá variar consideravelmente de um contexto social e histórico para outro, e os políticos poderão ter surpresas quando, em contextos onde há alto grau de sensibilidade à corrupção, até mesmo deslizes relativamente pequenos podem se tornar motivo de renúncia. ${ }^{128}$
}

Essa passagem de Thompson aponta exatamente esse caráter histórico de conceitos vinculados a questões de moralidade pública, no qual podemos alocar a ideia de decoro. Vemos, com isso, que a imprecisão, indeterminação e fluidez do conceito em tela, consoante observamos na Constituição de 1988, tem sua razão de ser, já que é uma maneira de abranger situações das mais diversas na qual houvesse por parte do cidadão a formação de uma imagem desprestigiosa e negativa do Parlamento, tendo em vista fatos envolvendo representantes parlamentares.

Mas se a imprecisão do conceito de conduta indecorosa é uma necessidade inerente ao objetivo do instituto da cassação por quebra de decoro, qual seja, a defesa da moralidade institucional, impende constatar que, "mesmo que os conceitos versados na hipótese da norma ou em sua finalidade sejam vagos, fluidos ou imprecisos, ainda assim têm algum conteúdo determinável, isto é, certa densidade mínima". ${ }^{129}$ Nesse sentido, reafirmamos que o procedimento declarado como indecoroso não se traduz em um conceito que possa ser

${ }^{128}$ THOMPSON, John B. O escândalo político: poder e visibilidade na era da mídia. Petrópolis: Vozes, 2002, p. 48.

129 MELLO, Celso Antônio Bandeira de. Discricionariedade e controle jurisdicional. São Paulo: Malheiros, 2003, p. 28. 
manejado pelas Casas legislativas ao seu bel-prazer. A Constituição não atribui competência para a cassação de mandato parlamentar por "qualquer conduta" ou "por capricho da maioria", mas somente no caso de ofensa à dignidade e à honorabilidade do Poder Legislativo. Eis uma compreensão que não pode ser afastada sem a deturpação do instituto; nesses termos, Celso Ribeiro Bastos identifica que:

O que parece certo é que o constituinte não quis encampar toda e qualquer forma de moralidade, mas apenas aquela cuja lesão possa depor contra o decoro parlamentar, ou seja, contra a nobreza, a dignidade, cuja degradação possa influir no próprio conceito do Parlamento. [...] Não se trata de coisas que se passam no foro íntimo de cada um, mas de comportamentos, de atitudes que, pelo seu caráter incompatível com o bom proceder de um parlamentar, acabam por depor contra a própria reputação da instituição. ${ }^{130}$

Essas lições de Celso Ribeiro Bastos nos levam a considerar o problema do decoro a partir de um ponto de vista público, ou melhor, como uma temática que envolve relações de natureza política, ${ }^{131}$ neste caractere reside a sua peculiaridade enquanto instituto constitucional. Se quisermos encontrar algum sentido mínimo para o conceito de decoro, como propomos no início deste topico, é necessário compreender essa discussão sempre pelo viés político, pela dinâmica das relações democráticas entre representantes e representados. Por isso, o decoro não se identifica com o horror que cada membro do Poder Legislativo tem em relação a certas situações enfrentadas por seus pares; pelo contrário, deve, antes, se relacionar com a constatação de uma circunstância política constrangedora para a instituição parlamentar. Nessa ordem de ideias, podemos afirmar que a situação política que de início não constrange objetivamente o parlamento, ou não possa levar razoavelmente a tal interpretação, não pode ser considerada ofensiva ao decoro.

${ }^{130}$ BASTOS, Celso Ribeiro; MARTINS, Ives Gandra. Comentários à Constituição do Brasil. São Paulo: Saraiva, 1999. v. 4, t. I, p. 236.

${ }^{131}$ Essa identidade entre a ideia de público e a política foi bem analisada por Bobbio quando abordou a questão a partir da dicotomia público $x$ privado, de modo a caracterizar outras distinções binárias, por exemplo, entre política e economia (BOBBIO, Norberto. Estado, governo, sociedade: para uma teoria geral da política. São Paulo: Paz e Terra, 2010, p. 13-17). Nesses termos, podemos também compreender a ideia de decoro parlamentar como oposta ao decoro realizado na vida privada. 
Com autoridade, Miguel Reale tratou o assunto no mesmo sentido:

No fundo, falta de decoro parlamentar é falta de decência no comportamento pessoal, capaz de desmerecer a Casa dos representantes (incontinência de conduta, embriaguez etc.) e falta de respeito e dignidade do Poder Legislativo, de modo a expô-lo a críticas infundadas, injustas e irremediáveis, de forma inconveniente. ${ }^{132}$

Com isso, fica clara a distinção entre mero moralismo subjetivista - isto é, que está apenas circunscrito à avaliação do indivíduo e seus valores particularistas - e a ofensa objetiva à moralidade institucional - que somente é observável a partir de uma análise política dos efeitos públicos da ação perpetrada pelo representante parlamentar. Por isso, o decoro parlamentar pertence ao lócus político, ao Poder Legislativo, que requer de seu agente representativo certa dignidade. Nesses termos, Sampaio Doria ensina que "decoro é a dignidade específica, o respeito do homem digno à posição que ocupa, às funções que exerça, ao meio onde se ache". ${ }^{133}$

É assim correto afirmar que, "incompatível com o decoro parlamentar é todo ato do deputado ou senador que, por sua natureza, imoral ou antijurídica, provoque repúdio da sociedade". 134

Por óbvio que essa forma de abordagem interpretativa não é capaz de sanar todas as dúvidas quanto à ocorrência de conduta ofensiva ao decoro - existem, pois, fatos que serão de difícil metrificação quanto ao impacto político que causam em relação ao Parlamento, tornando complicada a análise quanto ao seu enquadramento como conduta incompatível com o decoro. Tal conclusão, entretanto, não invalida a construção analítica que realizamos até aqui; pelo contrário, reforça a necessidade de que a interpretação do art. 55, II, da Constituição sempre parta dessa perspectiva na qual se enfatiza a relação política e a necessidade de defesa institucional do Parlamento e das instituições democráticas.

${ }^{132}$ REALE, Miguel. Decoro parlamentar e cassação de mandato eletivo. São Paulo: Revista dos Tribunais, 1969, p. 89.

${ }_{133}$ DORIA, A. de Sampaio. Direito constitucional: comentários à Constituição de 1946. São Paulo: Max Limonad, 1960. v. 2, p. 235.

${ }^{134}$ JÚNIOR, José Cretella. Comentários à Constituição brasileira de 1988. Rio de Janeiro: Forense Universitária, 1992. v. V, p. 2.665. 
Oportuno, então, darmos mais um passo em nosso estudo, observando que a Constituição, ao estipular que a "conduta incompatível com o decoro" é causa a dar ensejo à aplicação da pena de perda de mandato, não proíbe que dentro da ordem normativa constitucional ou infraconstitucional existam previsões de condutas e fatos objetivos que configurem ofensa ao decoro. Importa, nesse passo, verificar que a Constituição, embora não tenha estipulado um conceito determinado e objetivo do que seria um comportamento incompatível com o decoro e a dignidade do Parlamento, acabou por indicar no $\S 1^{\circ}$ do art. 55 que "é incompatível com o decoro parlamentar, além dos casos definidos no regimento interno, o abuso das prerrogativas asseguradas a membro do Congresso Nacional ou a percepção de vantagens indevidas", isto é, estabeleceu duas hipóteses que, uma vez constatadas, redundam inarredavelmente em procedimento indecoroso. Segundo Manoel Gonçalves Ferreira Filho, a intenção dessa previsão era abranger de forma inquestionável o abuso de prerrogativas e a percepção de vantagens indevidas na esfera dos atos incompatíveis com o decoro parlamentar. ${ }^{135}$

Parece-nos prudente, em consonância com o que afirmamos anteriormente, deixar assente que não há redução da conduta indecorosa apenas a essas duas hipóteses, há apenas uma constitucionalização de duas práticas que, uma vez verificadas, não podem ser postas em dúvida quanto ao seu enquadramento como uma conduta ofensiva à dignidade parlamentar. Assim, essas duas estipulações constitucionais não tornam determinado o conceito de decoro, configurando-se apenas como espécies do gênero decoro.

Mas devemos nos perguntar em que consiste, objetivamente, o abuso de prerrogativas e a percepção de vantagens indevidas?

Sabemos que o regime jurídico parlamentar é a particularização de direitos e deveres próprios aos agentes políticos que exercem mandato no âmbito do Poder Legislativo. Nessa perspectiva, encontramos na Constituição Federal de 1988, em seus arts. 53 a 56, as regras aplicáveis a deputados e senadores, prerrogativas e sujeições que exorbitam o direito comum visando atender às necessidades inerentes ao status político que gozam. Diz-se, então, que essas regras constitucionais consubstanciam o Estatuto do Congressista, ${ }^{136}$ do mesmo modo que todos aqueles que atuam na esfera do Aparelho do Estado, como servidores efetivos, estão

${ }^{135}$ FERREIRA FILHO, Manoel Gonçalves. Comentários à Constituição brasileira de 1988. São Paulo: Saraiva, 1992. v. 2, p. 57.

${ }^{136}$ BULOS, Uadi Lammêgo. Curso de direito constitucional. São Paulo: Saraiva, 2011, p. 1.076. 
submetidos a um estatuto específico. Tanto as prerrogativas quanto as sujeições a que se submetem os parlamentares têm o objetivo claro de garantir o exercício livre e independente do mandato, na medida em que só assim é possível guiar sua atuação em direção ao interesse público.

Com efeito, por exemplo, vemos na Constituição que é vedado ao congressista firmar ou manter contrato com pessoa jurídica de direito público, ${ }^{137}$ sendo, ao mesmo tempo, garantida a inviolabilidade penal e civil por quaisquer de suas opiniões, palavras e votos ${ }^{138}$. Temos aqui vedações e prerrogativas que são impensáveis na esfera privada do cidadão e que apenas encontra justificação no campo político.

Centrando nossa análise apenas no aspecto das prerrogativas, observa-se que o seu abuso se dá sempre que o agente parlamentar vai além daquilo que lhe é facultado pela norma. Como já dissemos, a Constituição e as leis estabelecem as prerrogativas sempre como um instrumento de garantia ao exercício do mandato - é esta a determinação do art. $2^{\circ}$ do Código de Ética e Decoro Parlamentar da Câmara dos Deputados, ao salientar que: "As imunidades, prerrogativas e franquias asseguradas pela Constituição, pelas leis e pelo Regimento Interno da Câmara dos Deputados aos Deputados são institutos destinados à garantia do exercício do mandato popular e à defesa do Poder Legislativo". Com efeito, as faculdades que gozam os membros do legislativo devem ser utilizadas de forma razoável e sem excesso. Nas palavras de José Cretella Júnior:

Prerrogativas são privilégios que derivam do status da pessoa, na sociedade. O parlamentar deve usufruir dessas prerrogativas, dentro da lei, não ultrapassando determinados limites, o que, verificado, poderá configurar infração ao decoro parlamentar. [...] Abuso nas palavras, nos votos e nas opiniões pode, assim, ser imoral, obsceno, indecoroso, tendo como consequência a perda do mandato eletivo, em razão desse tipo de procedimento.

É preciso, então, na situação de abuso dessas prerrogativas específicas, atentar para aquilo que realmente configure ofensa ao decoro institucional do Parlamento. Não se pode perseguir parlamentar ameaçando-o de cassação por sua atuação mais incisiva em relação ao governo ou aos seus pares. Como afirma Miguel Reale, "grave risco cercaria o regime

${ }^{137}$ Art. 54, I, $a$, da Constituição Federal.

${ }^{138}$ Art. 53, caput, da Constituição Federal 
democrático se 'faltar ao decoro parlamentar' viesse a significar, também, pretensos excessos praticados pelo parlamentar no exercício de seu dever de crítica e de fiscalização dos negócios públicos". 139

Nessa perspectiva, por exemplo, o Regimento Interno da Câmara dos Deputados prevê competência de sua Mesa para adotar todas as providências cabíveis, por solicitação do interessado, para a defesa judicial e extrajudicial de Deputado contra a ameaça ou a prática de ato atentatório do livre exercício e das prerrogativas constitucionais do mandato parlamentar. $^{140}$

A segunda prática tida pela Constituição de 1988 como conduta indecorosa é a percepção de vantagens indevidas. Importante lembrar que, antes de analisarmos a Emenda 01/69, observamos que o art. $35, \S 1^{\circ}$, considerou incompatível com o decoro parlamentar "a percepção, no exercício do mandato, de vantagens ilícitas ou imorais", nossa atual Constituição de linhagem liberal democrática apenas remete a vantagens indevidas, o que também deixa uma margem grande de subjetivismo para a análise de cada fato. Dizer o que é devido ou indevido em termos de vantagens recebidas por parlamentares, sejam elas materiais ou não, dependerá não somente de verificar a sua legalidade mas também do modo como a percepção de tal vantagem é considerada moralmente pelo parlamento e pela sociedade, e o quanto isso impacta na imagem pública do Poder Legislativo.

Assim, podemos concluir que, no plano constitucional, as duas práticas inseridas no $\S$ $1^{\circ}$, do art. 55 , não configuram condutas objetivas e exatas, mas estão igualmente marcadas por certo grau de imprecisão, embora representem maior determinação do que a própria ideia de decoro.

Feitas essas considerações, ressalte-se que a Constituição deferiu a cada uma das Casas legislativas o poder para definir em seus respectivos Regimentos Internos outras hipóteses de condutas incompatíveis com o decoro parlamentar.

O Regimento Interno, ${ }^{141}$ segundo as lições de Ruy Barbosa, é "a lei de cada uma das legislaturas dictado a si mesmo", ${ }^{42}$ ou seja, é constituído pelas regras infraconstitucionais que

${ }^{139}$ REALE, Miguel. Decoro parlamentar e cassação de mandato eletivo, cit., p. 88.

${ }^{140}$ Art. 15, IX, do RICD.

${ }^{141}$ Segundo Pinto Ferreira, "a origem histórica dos regimentos remonta à Inglaterra, nos velhos artigos do Modus Tenendi Parliamentum. Costumes seculares foram se consolidando na Inglaterra, e já na época de Eduardo VI (1537-1553) as principais regras do direito parlamentar, denominadas standing orders, eram aceitas. Em 1844, existiam catorze delas na Câmara dos Comuns" (FERREIRA, Pinto. Comentários à Constituição brasileira. São Paulo: Saraiva, 1990. v. 2, p. 587). 
organizam o funcionamento interno das Casas congressuais, seus procedimentos e a disciplina parlamentar, ${ }^{143}$ são consideradas no mesmo nível das leis ordinárias, se diferenciando apenas quanto a sua natureza interna corporis, ${ }^{144}$ no sentido que são de competência e aplicação interna ao Parlamento, não sendo, assim, direcionadas diretamente à sociedade como um todo. É por lógica que essas regras internas não poderiam ser ditadas de órgãos superiores externos às próprias Casas congressuais, pois, se isso ocorresse, estaria violada a independência funcional garantida no art. $2^{\circ}$ da Constituição Federal. Assim, temos que o poder de autoorganização é atribuído pela Constituição a cada uma das Casas legislativas (art. 51, III, e art. 52, XII, da Constituição Federal).

É no exercício dessa competência constitucional de auto-organização que Câmara e Senado podem estabelecer hipóteses de condutas violadoras ao decoro parlamentar para além daquelas previstas no texto constitucional. Contudo, como já tivemos oportunidade de fazer referência, embora a elaboração dos regulamentos internos por cada uma das Casas legislativas configure um ato de natureza interna corporis, o exercício dessa competência encontra limites no próprio texto constitucional. Nesses termos, José Afonso da Silva é categórico ao afirmar que os atos interna corporis, apesar de serem expressão da soberania parlamentar, devem prestar vassalagem à própria Constituição, cuja soberania é superior. ${ }^{145}$

Encontramos lição em diapasão com nossa análise em Carlos Maximiliano, o qual, ao comentar a Constituição de 1946, aduz que "Não pode o Regimento Interno violar direitos fundamentais nem transpor as restrições da lei básica". ${ }^{146}$

Destarte, o próprio Poder Legislativo, por meio de cada uma de suas Casas, não pode criar novas hipóteses de condutas ofensivas ao decoro incompatíveis com o próprio texto constitucional. Passemos, então, ao estudo de como o tema foi tratado nos Regimentos, bem como nos Códigos de Ética e Decoro Parlamentar.

142 BARBOSA, Ruy. Comentários á Constituição federal brasileira. São Paulo: Saraiva, II volume, 1933, p. 32.

${ }^{143}$ AVRIL, Pierre; GICQUEL, Jean. Droit parlementaire. Paris: Montchrestien, 2004, p. 07.

144 SILVA, José Afonso da. Processo constitucional de formação das leis. São Paulo: Saraiva, 2003, p. 344. Houve quem discordasse dessa perspectiva - ver, nesse sentido, os dizeres de Duguit: "Il importe de bien compreendre que les règlements des chambres ne sont pas des loi, mais simplement des résolutions" (DUGUIT, Léon. Traité de droit constitutionnel. Paris: Ancienne Librairie Fontemoing \& Cie/E. de Boccard, 1924, p. 273).

${ }^{145}$ SILVA, José Afonso da. Processo constitucional de formação das leis, cit., p. 344.

${ }^{146}$ MAXIMILIANO, Carlos. Comentários à Constituição brasileira. Rio de Janeiro: Freitas Bastos, 1948. v. II, p. 25. 


\subsection{Regimento Interno da Câmara dos Deputados (RICD)}

Por meio da Resolução n. 17 de 1989 foi aprovado o Regimento Interno da Câmara dos Deputados (RICD). O primeiro ponto a ser notado refere-se ao fato de que, no corpo da própria Resolução, houve previsão de que a Mesa da Câmara elaboraria e apresentaria posteriormente um projeto de Resolução sobre um Código de Ética e Decoro Parlamentar. (art. $3^{\circ}$ ). A preocupação do legislador parece ter sido no sentido de dar um tratamento específico e especializado sobre a questão da moralidade institucional e, por tal razão, acabou cindindo materialmente parte do Regimento Interno, ao prever um Código de Ética a ser elaborado e instituído posteriormente.

No art. 231, o Regimento Interno estabeleceu que, no exercício do mandato, o Deputado atenderá às prescrições constitucionais e regimentais, inclusive as contidas no Código de Ética e Decoro Parlamentar, sujeitando-se às medidas disciplinares nelas previstas. O RICD acabou também reproduzindo as hipóteses de perda de mandato parlamentar em seu art. 240, ${ }^{147}$ alocando em seu rol a conduta declarada incompatível com o decoro parlamentar.

Por fim, determinou no art. 244, com a redação dada pela Resolução n. 25/2001, que o deputado que pratica ato contrário ao decoro parlamentar ou que afete a dignidade do mandato estará sujeito às penalidades e ao processo disciplinar previstos no Código de Ética e Decoro Parlamentar, que definirá também as condutas puníveis. Com efeito, verificamos que o RICD não trouxe hipóteses de procedimentos indecorosos, ficando limitado ao próprio grau de generalidade constitucional ao repetir suas hipóteses. Nesses termos, conclui-se que a opção

${ }^{147}$ Art. 240. Perde o mandato o Deputado:

I - que infringir qualquer das proibições constantes do art. 54 da Constituição Federal;

II - cujo procedimento for declarado incompatível com o decoro parlamentar;

III - que deixar de comparecer, em cada sessão legislativa ordinária, à terça parte das sessões ordinárias da Câmara, salvo licença ou missão autorizada;

IV - que perder ou tiver suspensos os direitos políticos;

V - quando o decretar a Justiça Eleitoral, nos casos previstos na Constituição Federal;

VI - que sofrer condenação criminal em sentença transitada em julgado.

$\S 1^{\circ}$ Nos casos dos incisos I, II e VI, a perda do mandato será decidida pela Câmara dos Deputados, em escrutínio secreto e por maioria absoluta de votos, mediante provocação da Mesa ou de Partido com representação no Congresso Nacional, assegurada ampla defesa.

$\S 2^{\circ}$ Nos casos previstos nos incisos III a V, a perda do mandato será declarada pela Mesa, de ofício ou mediante provocação de qualquer Deputado, ou de Partido com representação no Congresso 
do legislador foi deixar a questão de se introduzir nova hipótese de conduta indecorosa para ser resolvida pelo Código de Ética e Decoro Parlamentar.

\subsection{Código de Ética e Decoro Parlamentar da Câmara dos Deputados}

A Resolução n. 25/2001 instituiu o Código de Ética e Decoro Parlamentar da Câmara dos Deputados, estabelecendo, em seu art. $1^{\circ}$, parágrafo único, que suas normas complementam o Regimento Interno e dele passam a ser parte integrante. Com efeito, podemos concluir pela natureza Regimental do Código, ${ }^{148}$ o que o torna apto a prever novas hipóteses de condutas ofensivas à dignidade do Parlamento, já que é um requisito constitucional o de que novas hipóteses de procedimentos incompatíveis com o decoro parlamentar sejam previstas regimentalmente.

O Código de Ética e Decoro Parlamentar da Câmara tem o papel de estabelecer os princípios éticos e as regras básicas de decoro que devem orientar a conduta dos que estejam no exercício do cargo de Deputado Federal (art. $1^{\circ}$ ). Para o momento, importa-nos lançar o olhar no modo como o Código tratou das condutas ofensivas ao decoro.

De início, faz-se necessário constatar que o Código de Ética da Câmara, no que atina ao fenômeno do decoro, realiza uma distinção não encontrada no âmbito do texto constitucional; assim, ao lado dos procedimentos enquadrados como incompatíveis com o decoro parlamentar, previstos no art. $4^{\circ}$, o Código estabelece, em seu art. $5^{\circ}$, condutas consideradas atentatórios ao decoro parlamentar. Impende, nesse sentido, salientar que não há qualquer referência ou indicação quanto ao critério utilizado para distinguir o procedimento incompatível com o decoro de um ato que atenta contra o decoro. De modo geral, poderíamos até interpretar que aquilo que é atentatório ao decoro é também incompatível com o decoro, sendo muito difícil na mera utilização desses termos chegarmos a alguma conclusão.

Para compreender o princípio de distinção (critério) que separa aquilo que é incompatível com o decoro daquilo que é atentatório ao decoro, devemos voltar nossa análise para os efeitos jurídicos que envolvem cada uma dessas situações. No caso do ato

${ }^{148}$ CALIMAN, Auro Augusto. Mandato parlamentar: aquisição e perda antecipada. São Paulo: Atlas, 2005 , p. 175. 
incompatível ao decoro, o deputado poderá ser punido com a perda do mandato, ${ }^{149}$ nos termos do art. 55, II, da Constituição, enquanto nas hipóteses de condutas atentatórias ao decoro, as penas previstas são censura, verbal ou escrita, passando pela suspensão de prerrogativas regimentais por até 6 (seis) meses, chegando, no máximo, à suspensão por 6 (seis) meses do exercício do mandato. ${ }^{150}$

Com efeito, o legislador regimental da Câmara dos Deputados quis induzir uma gradação nas penalidades, considerando certas situações como menos gravosas do que outras; dessa forma, as circunstâncias previstas no art. $4^{\circ}$ do Código são tidas como mais graves do ponto de vista da ofensa moral, sendo, por isso, passíveis de serem apenadas com a perda do mandato, enquanto as hipóteses previstas no art. $5^{\circ}$ são postas como circunstâncias nas quais a perda de mandato seria um ato excessivo diante da gravidade menor das condutas previstas.

A seguir, importa-nos explorar as condutas incompatíveis com o decoro previstas no Código de Ética da Câmara e, na sequência, voltar nossa análise para os atos atentatórios ao decoro, objetivando averiguar a pertinência dessa separação feita na esfera regimental.

Já dissemos que o art. $4^{\circ}$ do Código definiu procedimentos incompatíveis com o decoro parlamentar, puníveis com a perda de mandato, e tal disposição está em diapasão com o art. 55, II, $\S 1^{\circ}$, da Constituição, que concede competência aos regimentos para apresentar outras hipóteses de perda de mandato para além daquelas especificadas na própria Constituição.

A primeira dessas condutas incompatíveis com o decoro parlamentar é exatamente a de "abusar das prerrogativas constitucionais asseguradas aos membros do Congresso Nacional", ${ }^{151}$ isto é, a mesma causa já prevista na Constituição Federal, em seu art. 55, § $1^{\circ}$, mas devemos observar que não se trata de mera repetição do texto constitucional, pois que o Código fala em abuso de prerrogativas constitucionais, enquanto a Constituição apenas remete ao abuso de prerrogativas asseguradas ao membro do Congresso Nacional, sem fazer qualquer referência quanto ao status da prerrogativa, se constitucional ou infraconstitucional.

De maneira geral, essa modificação realizada pelo legislador regimental não causa grande transtorno, uma vez que, em regra, as prerrogativas garantidas aos membros do Congresso Nacional são aquelas previstas na Constituição. Todavia, pode-se aventar de abuso de prerrogativas não deferidas no Texto Maior de forma geral a todo Congressista, mas

${ }^{149}$ Art. 14, § $3^{\circ}$, do Código de Ética e Decoro Parlamentar da Câmara dos Deputados.

${ }^{150}$ Ver arts. 11, 12, 13 e 14, $\S 1^{\circ}$, do Código de Ética e Decoro Parlamentar da Câmara dos Deputados.

${ }^{151}$ Art. $4^{\circ}$, I, do Código de Ética e Decoro Parlamentar da Câmara dos Deputados. 
prerrogativas específicas previstas no Regimento Interno. ${ }^{152}$ Por óbvio, nesses casos, poderá ocorrer ofensa ao decoro e eventual perda de mandato por meio da deliberação de cassação submetida aos membros da Câmara - tudo irá depender do modo como esses abusos ocorrem e como resvala na imagem prestigiosa do Parlamento.

A segunda hipótese elencada pelo Código é a percepção, a qualquer título, em proveito próprio ou de outrem, no exercício da atividade parlamentar, de vantagens indevidas. ${ }^{153}$ Constata-se que há uma maior minúcia do texto regimental em relação a essa hipótese do que aquela aventada pela Constituição, a qual se limita a estatuir que perca o mandato todo congressista que venha a receber vantagens indevidas.

O Código é claro ao não possibilitar que se interprete a norma constitucional no sentido de que somente a percepção de vantagens para o próprio deputado faltoso configuraria a ofensa ao decoro, ou seja, a vantagem pode ser tanto para proveito próprio como de outrem. Ademais, a vantagem pode ser a qualquer título, pouco importando se o deputado teve ou não algum dispêndio para obter a vantagem, o que importa é que ela foi indevida.

Um último aspecto relevante em relação a essa segunda definição de conduta indecorosa especificada pelo Código é o uso da expressão "no exercício do mandato" e, de fato, quando lemos a Constituição, não há qualquer exigência clara e objetiva de que a percepção da vantagem indevida tenha que ser recebida durante o exercício do mandato para que se configure a quebra de decoro. Deixemos apenas constatado isso por enquanto, pois, em momento oportuno, verificaremos que essa redação dada pelo Código tem sérias implicações quanto à aplicabilidade do procedimento de cassação por quebra de decoro.

\footnotetext{
${ }^{152}$ Nesses termos, podemos apontar os direitos garantidos a todos os deputados no art. 226 do Regimento Interno, que diz: “O Deputado deve apresentar-se à Câmara durante a sessão legislativa ordinária ou extraordinária, para participar das sessões do Plenário e das reuniões de Comissão de que seja membro,

além das sessões conjuntas do Congresso Nacional, sendo-lhe assegurado o direito, nos termos deste Regimento, de:

I - oferecer proposições em geral, discutir e deliberar sobre qualquer matéria em apreciação na Casa, integrar o Plenário e demais colegiados e neles votar e ser votado;

II - encaminhar, através da Mesa, pedidos escritos de informação ao Ministro de Estado;

III - fazer uso da palavra;

IV - integrar as Comissões e representações externas e desempenhar missão autorizada;

V - promover, perante quaisquer autoridades, entidades ou órgãos da administração federal, estadual ou municipal, direta ou indireta e fundacional, os interesses públicos ou reivindicações coletivas de âmbito nacional ou das comunidades representadas;

VI - realizar outros cometimentos inerentes ao exercício do mandato ou atender a obrigações político-partidárias decorrentes da representação."

${ }^{153}$ Art. $4^{\circ}$, II, do Código de Ética e Decoro Parlamentar da Câmara dos Deputados.
} 
O terceiro procedimento julgado incompatível com o decoro pelo Código é a celebração de acordo que tenha por objeto a posse do suplente, condicionando-a à contraprestação financeira ou à prática de atos contrários aos deveres éticos ou regimentais dos deputados. ${ }^{154}$ Realizar acordo que tenha por objeto posse de suplente é negociar a própria representação política, violando as regras formais do jogo democrático contemporâneo, fraudando a lei e a própria vontade popular. A conduta que configura quebra de decoro nos termos do Código é a mera celebração do acordo, uma vez que nela já se induz um caráter negativo do ponto de vista da moralidade pública, daquilo que se espera de reputação e decência de uma agente parlamentar. Assim, não se requer que ocorra a posse da suplência negociada e nem mesmo que esta seja possível efetivamente, basta que se coloque, de um lado, a promessa da posse e, de outro, a contraprestação financeira ou a prática de atos contrários aos deveres éticos ou regimentais. A quebra do decoro se coloca exatamente no conteúdo do acordo firmado.

Cabe lembrar que as regras constitucionais de suplência tanto para o Senado quanto para a Câmara determinam que o suplente seja convocado nos casos de vaga, de investidura em funções de Ministro de Estado, Governador de Território, Secretário de Estado, do Distrito Federal, de Território, de Prefeitura de Capital ou chefe de missão diplomática temporária, ou de licença superior a cento e vinte dias. ${ }^{155}$

Nos termos do Regimento Interno da Câmara dos Deputados, a vacância se verifica no caso de falecimento, renúncia ou perda do mandato; ${ }^{156}$ com efeito, qualquer uma dessas situações legitimam a convocação de suplente pela Mesa.

A quarta conduta trazida pelo Código como ofensiva ao decoro parlamentar é fraudar, por qualquer meio ou forma, o regular andamento dos trabalhos legislativos para alterar o resultado de deliberação. ${ }^{157}$ A deliberação no âmbito do Legislativo é o momento de decisão política fundamental no qual todo processo democrático flui no sentido de dar ensejo a regras de direito a serem impostas à sociedade de modo legítimo. A deliberação nas Casas legislativas se dá por meio de regras constitucionais e regimentais conhecidas e aceitas, de modo que a sua violação implica fraudar a Constituição e a vontade popular, e por tal motivo

\footnotetext{
${ }_{154}$ Art. $4^{\text {o }}$, III, do Código de Ética e Decoro Parlamentar da Câmara dos Deputados.

155 Art. 56, I, da Constituição Federal.

156 Art. 238 do RICD.

${ }^{157}$ Art. $4^{\circ}$, IV, do Código de Ética e Decoro Parlamentar da Câmara dos Deputados.
} 
dá ensejo à perda do mandato por quebra de decoro. É essa uma situação que não pode ser aceita, sob pena de macular de maneira inequívoca a honra e o prestígio do Parlamento, que, em vez de ser visto (imagem) como um local de decisões legítimas, se torna um lócus de fraude à vontade popular.

A quinta causa prevista pelo Código como ofensiva à dignidade parlamentar ocorre quando o deputado omitir intencionalmente informação relevante ou, nas mesmas condições, prestar informação falsa nas declarações obrigatórias previstas no próprio Código. ${ }^{158} \mathrm{~A}$ princípio, devemos observar que a intenção do agente é essencial à configuração da quebra de decoro, ou seja, não basta simplesmente omitir, é preciso constatar objetivamente que essa era sua intenção deliberada. Esse requisito, logicamente, só pode ser observado nas circunstâncias que rondam o caso concreto. Para além da intenção, o Código requer, em um primeiro momento, que a omissão se dê quanto a informações relevantes, sem, todavia, apontar o que seja objetivamente "relevante". Nossa interpretação é a de que relevante é aquilo que moral e politicamente se coloca como tal - assim, do deputado se espera transparência e honestidade. Nessa ordem de ideias, se determinada informação, que diga respeito a possíveis conflitos de interesses com a função pública, é omitida pelo parlamentar, tal circunstância pode gerar um julgamento público negativo tanto em relação à sua pessoa como em relação à Casa legislativa, de modo a torná-lo passível de ter instaurado contra si o procedimento de cassação de mandato por quebra de decoro.

Importante ressaltar que não é apenas a omissão de informações relevantes que configura quebra de decoro, consoante as determinações do art. $4^{\circ}$, V, do Código de Ética, mas também a prestação de informações obrigatórias falsas. Existem, pois, informações que, para o deputado, são de prestação obrigatória e devem ser repassadas de maneira honesta e fidedigna. Vale, então, colacionarmos a seguir essas declarações obrigatórias, conforme trazidas pelo Código de Ética:

Art. 18. O Deputado apresentará à Mesa ou, no caso do inciso II deste artigo, quando couber, à Comissão, as seguintes declarações:

I - ao assumir o mandato, para efeito de posse, bem como quando solicitado pelo órgão competente da Câmara, dos Deputados "Autorização de Acesso aos Dados das Declarações de Ajuste Anual do Imposto de Renda Pessoa Física" e às respectivas retificações entregues à

\footnotetext{
${ }^{158}$ Art. $4^{\text {o }}, \mathrm{V}$, do Código de Ética e Decoro Parlamentar da Câmara dos Deputados.
} 
Secretária da Receita Federal do Brasil, para os fins de cumprimento da exigência contida no art. 13 da Lei n. 8.429, de 2 de junho de 1992, no art. $1^{\circ}$ da Lei n. 8.730, de 10 de novembro de 1993, e da Instrução Normativa TCU n. 65, de 20 de abril de 2011;

II - durante o exercício do mandato, em Comissão ou em Plenário, ao iniciar-se a apreciação de matéria que envolva direta e especificamente seus interesses patrimoniais, declaração de impedimento para votar.

Vemos aqui duas declarações obrigatórias: uma que de fato não é prestada inicialmente à Câmara, sendo apenas a cópia da declaração prestada à Receita Federal, o Ajuste Anual do Imposto de Renda Pessoa Física, e outra que é uma declaração de impedimento visando evitar que o parlamentar vote determinada matéria que tenha interesse patrimonial. Se houver prestação de informações falsas em qualquer uma dessas declarações, dependendo da gravidade, será configurada a quebra de decoro.

Por fim, o Código de Ética traz, como última hipótese de procedimento incompatível com o decoro, a prática de irregularidades graves no desempenho do mandato ou de encargos decorrentes que afetem a dignidade da representação popular. ${ }^{159}$ Esta última conduta é tão indeterminada quanto a ideia de procedimento incompatível com o decoro parlamentar, de modo que acaba acrescentando pouco ao conceito já previsto na Constituição. A única consideração importante é a de que essa regra aponta apenas para irregularidades graves no desempenho do mandato, não fazendo qualquer referência quanto aos atos extraparlamentares.

2.2.1 Dos atos atentatórios ao decoro em face do procedimento incompatível com o decoro

$\mathrm{O}$ art. $5^{\circ}$ do Código de Ética da Câmara, como já sublinhamos de forma genérica, tipifica hipóteses de atos atentatórios ao decoro, que teriam, tendo em vista as penalidades previstas, menor gravidade do que aquelas condutas enquadradas como incompatíveis com o decoro, que são apenadas com a perda do mandato nos termos do art. 55, II, da Constituição. Trata-se, pois, de criação do legislador regimental, não prevista no Texto Maior. O fundamento hipotético que justifica essa elaboração normativa é exatamente não colocar toda a conduta parlamentar indesejada sob a possibilidade de imputação como quebra de decoro;

${ }^{159}$ Art. $4^{\text {o }}$, VI, do Código de Ética e Decoro Parlamentar da Câmara dos Deputados. 
caso isso ocorresse, certos procedimentos de menor potencial ofensivo à dignidade parlamentar seriam apenados com a perda do mandato ou restariam impunes, pois a cassação do mandato seria a única opção punitiva prevista legalmente.

É com essa perspectiva que o art. $5^{\circ}$ do Código de Ética define dez hipóteses de atos que atentam contra o decoro parlamentar. São elas:

I - perturbar a ordem das sessões da Câmara dos Deputados ou das reuniões de Comissão;

II - praticar atos que infrinjam as regras de boa conduta nas dependências da Casa;

III - praticar ofensas físicas ou morais nas dependências da Câmara dos Deputados ou desacatar, por atos ou palavras, outro parlamentar, a Mesa ou comissão, ou os respectivos Presidentes;

IV - usar os poderes e prerrogativas do cargo para constranger ou aliciar servidor, colega ou qualquer pessoa sobre a qual exerça ascendência hierárquica, com o fim de obter qualquer espécie de favorecimento;

V - revelar conteúdo de debates ou deliberações que a Câmara dos Deputados ou Comissão hajam resolvido devam ficar secretos;

VI - revelar informações e documentos oficiais de caráter sigiloso, de que tenha tido conhecimento na forma regimental;

VII - usar verbas de gabinete ou qualquer outra inerente ao exercício do cargo em desacordo com os princípios fixados no caput do art. 37 da Constituição Federal;

VIII - relatar matéria submetida à apreciação da Câmara dos Deputados, de interesse específico de pessoa física ou jurídica que tenha contribuído para o financiamento de sua campanha eleitoral;

IX - fraudar, por qualquer meio ou forma, o registro de presença às sessões, ou às reuniões de comissão;

$\mathrm{X}$ - deixar de observar intencionalmente os deveres fundamentais do Deputado, previstos no art. $3^{\circ}$ deste Código.

Nesse ponto, não nos interessa analisar a conveniência de tais hipóteses nem como se caracterizam - trabalho que seria inútil diante do que nos propomos a estudar no presente capítulo -, mas, sim, deixar assentado que, dependendo das circunstâncias que envolvam as condutas ora descritas, elas podem configurar quebra de decoro, sendo, assim, passíveis de serem punidas com a cassação de mandato nos termos do art. 55, II, da Constituição; tudo dependerá do caso concreto. Vê-se isso claramente, por exemplo, no inciso VII, que prevê como atentatório ao decoro o uso de verba de gabinete ou qualquer outra inerente ao exercício 
do cargo em desacordo com os princípios fixados no caput do art. 37 da Constituição Federal. Por óbvio, situações como esta podem configurar quebra de decoro, e não mero ato atentatório ao decoro. O caput do art. 37 da Constituição traz os princípios fundamentais aplicáveis a toda esfera pública do Estado, como o princípio da legalidade, impessoalidade e moralidade, de modo que é no mínimo estranho afirmar de forma categórica e definitiva que, ao usar verba pública violando esses princípios, a conduta do parlamentar não possa ser considerada ofensiva ao decoro. Em verdade, de início, a interpretação podia ser bem o inverso disso.

Apenas para deixar as coisas no seu devido lugar, vale observar que no art. $5^{\circ}$, inciso IV, do Código é enquadrado como atentado contra o decoro a conduta de usar os poderes e prerrogativas do cargo para constranger ou aliciar servidor, colega ou qualquer pessoa sobre a qual exerça ascendência hierárquica, com o fim de obter qualquer espécie de favorecimento aqui, mais uma vez, não é possível dizer que sempre será assim. Ademais, não podemos esquecer que a própria Constituição, em seu art. $55, \S 1^{\circ}$, indica que o abuso de prerrogativas garantidas aos membros do Congresso Nacional tipifica procedimento incompatível com o decoro; logo, há, no mínimo, uma contradição entre os regramentos constitucional e regimental, pois ambos tratam do abuso de prerrogativas de modo distinto.

Concluímos essa análise dizendo que seria mais interessante se o legislador do Código de Ética limitasse a ditar somente a possibilidade de gradação de penas, conforme a gravidade das condutas parlamentares, reservando para as que ofendessem o prestígio e a dignidade do Parlamento a perda do mandato consoante disposição constitucional no art. 55, II, deixando para os casos menos gravosos as punições mais brandas.

\subsection{Regimento Interno do Senado Federal (RISF)}

O Regimento Interno do Senado Federal foi instituído pela Resolução n. 93/1970, e, tendo em vista a nova situação constitucional vivenciada no País a partir de 1988, teve seu conteúdo conformado pelas alterações introduzidas pela Resolução n. 18/1989. Em seu art. 32 trouxe também as mesmas determinações constitucionais a respeito das hipóteses de perda de 
mandato, prevendo, no inciso II, o procedimento declarado incompatível com o decoro parlamentar. $^{160}$

\subsection{Código de Ética e Decoro Parlamentar do Senado Federal}

O Código de Ética e Decoro Parlamentar do Senado Federal foi instituído pela Resolução n, 20/93. Uma primeira observação é a de que, em seu Capítulo III, o referido Código traz o título "Dos atos contrários à ética e ao decoro parlamentar", indicando a seguir, nos arts. $4^{\circ}$ e $5^{\circ}$, respectivamente, vedações ao senador e a condutas reputadas incompatíveis com o decoro. De modo objetivo, o que nos interessa nesse ponto são as condutas inseridas no art. $5^{\circ}$, pois nelas, segundo pode-se aferir da própria indicação do Código, estão dispostas as tipificações de condutas incompatíveis com o decoro.

Todavia, nesse contexto analítico, uma pergunta é inevitável, se o Capítulo III do Código inicia-se com o título "Dos atos contrários à ética e ao decoro", não seriam também as condutas vedadas no art. $4^{\circ}$ incompatíveis com o decoro na mesma medida que as descritas no art. $5^{\circ}$, já que ambos os artigos estão inseridos no mesmo título? Mais do que isso, quais seriam as distinções entre os arts. $4^{\circ}$ e $5^{\circ}$ ?

Importante ressaltar que tanto a violação das vedações do art. $4^{\circ}$ quanto a prática das condutas indecorosas previstas no art. $5^{\circ}$ são punidas com a perda do mandato a teor do art. 11, II, do Código, que tem a seguinte redação: “Serão punidas com a perda do mandato: [...] “a prática de qualquer dos atos contrários à ética e ao decoro parlamentar capitulados nos arts. $4^{\circ}$

${ }^{160}$ Art. 32. Perde o mandato o Senador:

I - que infringir qualquer das proibições constantes do art. 54 da Constituição;

II - cujo procedimento for declarado incompatível com o decoro parlamentar;

III - que deixar de comparecer à terça parte das sessões deliberativas ordinárias do Senado, em cada sessão legislativa anual, salvo licença ou missão autorizada;

IV - que perder ou tiver suspensos os direitos políticos;

V - quando o decretar a Justiça Eleitoral;

VI - que sofrer condenação criminal em sentença definitiva e irrecorrível.

$\S 1^{\circ}$ É incompatível com o decoro parlamentar o abuso das prerrogativas asseguradas ao Senador e a percepção de vantagens indevidas;

$\S 2^{\circ}$ Nos casos dos incisos I, II e VI, a perda do mandato será decidida pelo Senado Federal, por voto secreto e maioria absoluta, mediante provocação da Mesa ou de partido político representado no Congresso Nacional;

$\S 3^{\circ}$ Nos casos dos incisos III a V, a perda do mandato será declarada pela Mesa, de ofício ou mediante provocação de qualquer Senador, ou de partido político representado no Congresso Nacional, assegurada ampla defesa. 
e $5^{\circ}$. Assim, temos que o Código não distingue as situações que rondam ambos os artigos pela gravidade com relação à ética e ao decoro parlamentar; nesse ponto, o tratamento é idêntico, e a mesma penalidade é prevista.

Ora, se a punição prevista pelo Código para todas as condutas previstas em seus arts. $4^{\circ}$ e $5^{\circ}$ é a perda de mandato, impõe rememorarmos que o art. 55 da Constituição dispõe de forma taxativa todas as hipóteses de perda antecipada de mandato parlamentar, não sendo possível estendê-las por norma infraconstitucional a situações não previstas no próprio Texto Maior. ${ }^{161}$ Com efeito, todas as condutas e circunstâncias elencadas nos arts. $4^{\circ}$ e $5^{\circ}$ do Código devem ser analisadas à luz dos preceitos constitucionais. Destarte, para que as violações do art. $4^{\mathrm{o}}$ sejam legitimamente puníveis com a perda de mandato, é preciso que estejam enquadradas dentro de um dos seis incisos do art. 55 da Constituição. Caso as vedações do art. $4^{\circ}$ do Código configurem quebra de decoro parlamentar, devemos concluir pela total desnecessidade da distinção formal realizada entre essas vedações e as condutas incompatíveis com o decoro do art. $5^{\circ}$. No entanto, se as vedações não forem tipificações de condutas indecorosas e também não se enquadrarem em qualquer das previsões do art. 55 da Constituição, estaremos diante do fenômeno da inconstitucionalidade desses preceitos regimentais.

Feitas essas considerações, resta analisar o próprio art. $4^{\circ}$ do Código, visando solucionar eventuais problemas interpretativos. As duas primeiras previsões do referido artigo dispõem que é vedado ao senador:

I - celebrar contrato com instituição financeira controlada pelo Poder Público, incluídos nesta vedação, além do Senador como pessoa física, seu cônjuge ou companheira e pessoas jurídicas direta ou indiretamente por ele controladas;

II - dirigir ou gerir empresas, órgãos e meios de comunicação, considerados como tal pessoas jurídicas que indiquem em seu objeto social a execução de serviços de radiodifusão sonora ou de sons e imagens...

Como podemos verificar, trata-se formalmente de impedimentos ao exercício de certas atividades em concomitância com o mandato parlamentar, no mesmo sentido e amplitude das incompatibilidades previstas no art. 54 da Constituição. ${ }^{162}$ Ocorre, porém, que as

${ }^{161}$ CALIMAN, Auro Augusto. Mandato parlamentar: aquisição e perda antecipada, cit., p. 175.

162 Art. 54. Os Deputados e Senadores não poderão:

I - desde a expedição do diploma: 
incompatibilidades previstas na Constituição têm o objetivo de evitar, preventivamente, conflitos de interesse ${ }^{163}$ que possam macular a independência e a dignidade do mandato, não se confundindo com o fenômeno da quebra de decoro. Resta clara a não identidade entre os institutos na medida em que configuram, a teor do texto constitucional, hipóteses distintas de perda de mandato. A violação das vedações constitucionais do art. 54 torna possível a aplicação da perda de mandato com base no art. 55, I, da Constituição, enquanto a quebra de decoro fundamenta-se, como já estudamos, no inciso II do referido artigo.

Convém observar que o instituto jurídico constitucional da incompatibilidade parlamentar, assim como o da quebra de decoro, encontra seu fundamento político na moralidade pública, nas palavras de Pinto Ferreira:

... múltiplas são as causas que deram origem à consagração do instituto de incompatibilidades. Em primeiro lugar, domina a regra da impossibilidade material de realização simultânea das funções parlamentares com outras funções públicas. Há o problema do tempo, da necessidade de dedicação às atividades legislativas, vedando praticamente o bom cumprimento da vida parlamentar. [...] Em segundo lugar, a incompatibilidade exerce um efeito altamente moralizador e consagra a independência do Legislativo. Ela é indispensável a fim de proibir que os membros do Poder Legislativo, pelo seu prestígio e influência possam adquirir vantagens pessoais e econômicas, favorecendo os seus interesses. Teriam necessariamente que negociar o seu voto, em manobras indecorosas, que lhes permitissem a fruição de vantagens e favores ofertados. $^{164}$

a) firmar ou manter contrato com pessoa jurídica de direito público, autarquia, empresa pública, sociedade de economia mista ou empresa concessionária de serviço público, salvo quando o contrato obedecer a cláusulas uniformes;

b) aceitar ou exercer cargo, função ou emprego remunerado, inclusive os de que sejam demissíveis "ad nutum", nas entidades constantes da alínea anterior;

II - desde a posse:

a) ser proprietários, controladores ou diretores de empresa que goze de favor decorrente de contrato com pessoa jurídica de direito público, ou nela exercer função remunerada;

b) ocupar cargo ou função de que sejam demissíveis "ad nutum", nas entidades referidas no inciso I, "a";

c) patrocinar causa em que seja interessada qualquer das entidades a que se refere o inciso I, "a";

d) ser titulares de mais de um cargo ou mandato público eletivo.

${ }^{163}$ AVRIL, Pierre; GICQUEL, Jean. Droit parlementaire, cit., p. 38. FERREIRA FILHO, Manoel Gonçalves Curso de direito constitucional. São Paulo: Saraiva, 2010, p. 206.

${ }^{164}$ FERREIRA, Pinto. Comentários à Constituição Brasileira. São Paulo: Saraiva, 1992. v. 3, p. 04. 
No mesmo sentido, Pontes de Miranda afirma que as incompatibilidades “[...] fundamse em razões de ordem moral, que libertem os órgãos do povo dos tentáculos do Poder Executivo e das sugestões subornantes". ${ }^{165}$

As análises desenvolvidas anteriormente obrigam-nos a afirmar que as duas primeiras vedações determinadas pelo art. $4^{\circ}$ do Código de Ética do Senado não são, com certeza, condutas que por si só consubstanciam atos contrários à ética e ao decoro, mas são impedimentos regimentalmente previstos visando evitar possíveis conflitos de interesse no exercício do mandato.

Não vamos entrar aqui em discussões para além daquelas que sirvam para os propósitos de nosso estudo, ainda que seja uma questão interessante saber se os dois impedimentos trazidos pelo art. $4^{\circ}$, I e II, do Código não estariam em desacordo com a Constituição, uma vez que as incompatibilidades constantes do texto constitucional são taxativas, diga-se, encerram numerus clausus, não podendo, por isso, serem ampliadas por norma infraconstitucional. ${ }^{166}$ Entretanto, não é oportuno seguirmos nesse caminho.

Por último, como conduta vedada ao senador, o Código, em seu art. $4^{\circ}$, III, traz a prática do abuso do poder econômico no processo eleitoral. Essa conduta, sem dúvida, pode trazer impactos importantes para a imagem e a reputação do Poder Legislativo, levando-nos a concluir que estamos diante de prática indecorosa punível nos termos do art. 55, II, da Constituição. Para evitar possíveis confusões, contudo, vale lembrar que inciso IV do art. 55 da Constituição estabelece a perda do mandato parlamentar quando assim determinar a Justiça Eleitoral, de acordo com os casos previstos no próprio texto constitucional.

Na busca dos casos aventados pela Constituição, encontramos o art. 14, §10, prevendo que o mandato eletivo poderá ser impugnado ante a Justiça Eleitoral no prazo de quinze dias, contados da diplomação, instruída a ação com provas de abuso do poder econômico, corrupção ou fraude. Havendo procedência da ação, será decretada a anulação do diploma expedido pela Justiça Eleitoral, o que gerará a perda do direito subjetivo ao exercício do mandato que fora adquirido de forma ilegítima. ${ }^{167}$

\footnotetext{
165 MIRANDA, Pontes de. Comentários à Constituição de 1967, com a Emenda n. 01 de 1969. São Paulo: Revista dos Tribunais, 1970. t. III, p. 29.

${ }^{166}$ FERREIRA, Pinto. Comentários à Constituição Brasileira, cit., v. 3, p. 01.

${ }^{167}$ CALIMAN, Auro Augusto. Mandato parlamentar: aquisição e perda antecipada, cit., p. 160.
} 
Com efeito, a ocorrência do abuso do poder econômico em processo eleitoral pode fundamentar sentença ou acórdão judicial que determine a perda do mandato, a qual, nesse caso, será efetivada pela Câmara em cumprimento do art. 55, IV, da Constituição Federal. Assim, devemos compreender que a vedação ao abuso de poder econômico em processo eleitoral específico, consoante o Código, diz respeito à hipótese constante do art. 55, IV, da Constituição, não configurando, por óbvio, quebra de decoro. Quis o legislador regimental apenas repetir a norma constitucional.

Concluamos essas análises deixando firmado que, embora as condutas vedadas no art. $4^{\text {o }}$ do Código de Ética do Senado tenham um caráter moral, o que acaba por justificar a nomenclatura de seu Capítulo III como "Dos atos contrários à ética e ao decoro parlamentar", elas não constituem tipificações regimentais de procedimentos incompatíveis com o decoro parlamentar.

Cumpre agora guiar nosso estudo para as hipóteses previstas no art. $5^{\mathbf{o}}$, que, na literalidade do próprio Código de Ética, se propõe a dispor sobre os atos considerados incompatíveis com a ética e o decoro parlamentar.

O primeiro comportamento reputado incompatível com o decoro, conforme o art. $5^{\circ}, \mathrm{I}$, do Código, é o "abuso de prerrogativas constitucionais asseguradas aos membros do Congresso Nacional". Vê-se, nesse aspecto, que não há grandes inovações no campo do decoro, uma vez que essa já é uma situação abarcada pelo art. $55^{\circ}, \S 1^{\circ}$, da Constituição.

Já no inciso II, o art. $5^{\circ}$ do Código tipifica como incompatível com o decoro a "percepção de vantagens indevidas, tais como doações, ressalvados brindes sem valor econômico". Assim, o referido inciso repete em parte os termos do art. $55, \S 1^{\circ}$, da Constituição, inovando em relação ao texto constitucional, ao especificar que eventuais doações recebidas por senador configuram a percepção de vantagens indevidas, com exceção de brindes sem valor econômico. Todavia, vale ressaltar que a redação original do inciso, que foi alterada pela Resolução do Senado n. 43/2006, determinava não só as doações como vantagens indevidas mas também o recebimento de benefícios ou cortesias de empresas, grupos econômicos ou autoridades públicas.

Sobre a conjuntura política em que se deu a redação original do inciso, interessantes as análises elaboradas por Carla Costa Teixeira: 
Ao longo do processo de elaboração dos Códigos de Ética e Decoro Parlamentar, um evento teve grande influência sobre a tipificação das condutas indecorosas passíveis de sustentar um processo de perda de mandato. Embora os Códigos mantenham a "preservação da dignidade do mandato parlamentar" como missão maior, a chamada CPI do Orçamento, instaurada na primeira metade dos anos 90 para investigar esquemas de corrupção na Comissão Parlamentar Mista de Orçamento e que resultou na cassação de vários deputados federais, foi decisiva à focalização do bom desempenho da função política na garantia do não recebimento de vantagens ilícitas. Assim, nós podemos ler no Art. 5 do Código de Ética e Decoro Parlamentar do Senado a "percepção de vantagens indevidas" (prevista na Constituição Federal, art. 55, (parágrafo $1^{\circ}$ ) traduzida como "doações, benefícios ou cortesias de empresas, grupos econômicos ou autoridades públicas, ressalvados brindes sem valor econômico". Ou seja, podemos verificar a redução do entendimento do que sejam "vantagens indevidas" ao sentido de vantagens materiais indevidas. ${ }^{168}$

A última conduta tida como ofensiva ao decoro pelo Código de Ética do Senado é a "prática de irregularidades graves no desempenho do mandato ou de encargos decorrentes", prevista no inciso III do art. $5^{\circ}$. Diferentemente do Código de Ética da Câmara dos Deputados, que também define em seu art. $4^{\circ}$, VI, a prática de irregularidades graves como conduta incompatível com o decoro, o Código de Ética do Senado tipifica, exemplificativamente, no parágrafo único do art. $5^{\circ}$, duas situações que configuram irregularidades graves no exercício do mandato, quais sejam:

I - a atribuição de dotação orçamentária, sob a forma de subvenções sociais, auxílios ou qualquer outra rubrica, a entidades ou instituições das quais participe o Senador, seu cônjuge, companheira ou parente, de um ou de outro, até o terceiro grau, bem como pessoa jurídica direta ou indiretamente por eles controladas, ou ainda, que aplique os recursos recebidos em atividades que não correspondam rigorosamente às suas finalidades estatutárias;

II - a criação ou autorização de encargos em termos que, pelo seu valor ou pelas características da empresa ou entidade beneficiada ou contratada, possam resultar em aplicação indevida de recursos públicos.

Ambos os procedimentos especificados anteriormente têm um caráter imoral claro e, por tal razão, são tomados pelo Código como condutas ofensivas à dignidade parlamentar.

${ }^{168}$ TEIXEIRA, Carla Costa. Ética e política: velhas questões, novos atores. Brasília: Série Antropologia, 2005, p. 03. Disponível em: <http://vsites.unb.br/ics/dan/Serie387empdf.pdf〉. Acesso em: 20 jan. 2011. 
Como salientamos, trata-se de exemplificativas da prática de irregularidades no exercício do mandato e não subsumem a hipótese regimental desenhada no Código.

Não devemos esquecer que o Código de Ética do Senado Federal, para além das condutas puníveis com a perda de mandato, como as dispostas nos arts. $4^{\circ}$ e $5^{\circ}$, define outros procedimentos parlamentares que, em regra, são passíveis de medidas disciplinares menos drásticas, como a advertência, a censura e perda temporária do exercício do mandato $\left(\operatorname{art} .7^{\circ}\right)$, tendo em vista a gravidade menor que representam em face do decoro institucional. Com efeito, o Código de Ética do Senado estabelece gradação de penalidades, da mesma maneira em que ocorre na Câmara dos Deputados, consoante já tivemos oportunidade de analisar. O que nos interessa nessas condutas puníveis de maneira mais branda é o fato de que o Código deixa em aberto a possibilidade de cada uma delas serem apenadas com outras medidas disciplinares mais gravosas, conforme apreciação do próprio Senado. Dessa forma, temos as seguintes condutas e respectivas cominações narradas pelo Código:

Art. $8^{\circ}$ A advertência é medida disciplinar de competência dos Presidentes do Senado, do Conselho de Ética e Decoro Parlamentar ou de Comissão.

Art. $9^{\circ}$ A censura será verbal ou escrita.

$\S 1^{\circ}$ A censura verbal será aplicada pelos Presidentes do Senado, do Conselho de Ética e Decoro Parlamentar ou de Comissão, no âmbito desta, quando não couber penalidade mais grave, ao Senador que:

I - deixar de observar, salvo motivo justificado, os deveres inerentes ao mandato ou os preceitos do Regimento Interno;

II - praticar atos que infrinjam as regras da boa conduta nas dependências da Casa;

III - perturbar a ordem das sessões ou das reuniões.

$\S 2^{\circ}$ A censura escrita será imposta pelo Conselho de Ética e Decoro Parlamentar e homologada pela Mesa, se outra cominação mais grave não couber, ao Senador que:

I - usar, em discurso ou proposição, de expressões atentatórias ao decoro parlamentar;

II - praticar ofensas físicas ou morais a qualquer pessoa, no edifício do Senado, ou desacatar, por atos ou palavras, outro parlamentar, a Mesa ou Comissão, ou os respectivos Presidentes.

Art. 10. Considera-se incurso na sanção de perda temporária do exercício do mandato, quando não for aplicável penalidade mais grave, o Senador que:

I - reincidir nas hipóteses do artigo antecedente;

II - praticar transgressão grave ou reiterada aos preceitos do Regimento Interno ou deste Código, especialmente quanto à observância do disposto no art. $6^{\circ}$; 
III - revelar conteúdo de debates ou deliberações que o Senado ou Comissão haja resolvido devam ficar secretos;

IV - revelar informações e documentos oficiais de caráter reservado, de que tenha tido conhecimento na forma regimental;

V - faltar, sem motivo justificado, a dez sessões ordinárias consecutivas ou a quarenta e cinco intercaladas, dentro da sessão legislativa ordinária ou extraordinária. [Grifo nosso.]

Nessa ordem de ideias, constata-se que, excetuando a penalidade de advertência, para a qual o Código não indica qualquer conduta específica, em todas as hipóteses aventadas anteriormente a vinculação entre a conduta e a penalidade é relativa, ou seja, é sempre possível aplicar medida disciplinar mais grave, conforme as circunstâncias que envolvem cada caso, e não necessariamente aquela apontada pelo Código. Resta, então, concluirmos que, em todos esses procedimentos julgados menos gravosos, será possível também aplicar a penalidade de perda de mandato por quebra de decoro, embora, de início, não estejam enquadrados no rol dos atos ofensivos ao decoro do art. $5^{\circ}$ do Código. Assim, por exemplo, quando os senadores estiverem diante de uma situação na qual um de seus pares ofenda física ou moralmente qualquer pessoa, no edifício do Senado, ou desacate, por atos ou palavras, será viável aplicar a pena de perda de mandato por quebra de decoro em sintonia com os ditames do art. 55, II, da Constituição, deixando de aplicar a pena de censura escrita prevista especificamente para essa conduta no art. $9^{\circ}, \S 2^{\circ}$, II, do Código. Tudo dependerá da gravidade da conduta e do modo como resvala sobre a imagem e o prestígio do Parlamento. 


\section{CAPÍTULO 3 - HIPÓTESES DE CASSAÇÃO DE MANDATO POR QUEBRA DE DECORO NO CONSTITUCIONALISMO BRASILEIRO}

Todo instituto jurídico tem atrás de si um passado capaz de revelar sua gênese e sentido histórico. A partir de determinadas perspectivas, podemos dizer que uma norma jurídica reconhecida em certo ordenamento estatal é a resultante de um processo de luta política, na qual encontramos suas razões e seus motivos de existência. Essa é, sem dúvida, uma historicidade importante e imprescindível para o estudo de qualquer instituto jurídico. Com efeito, o instituto da cassação de mandato por quebra de decoro, nos moldes em que foi previsto no art. 55, II, da Constituição Federal de 1988, pode ser estudado a partir dessa perspectiva histórico-política sem maiores problemas. Entretanto, no presente momento, daremos centralidade metodológica a uma análise mais estritamente jurídica, isto é, fundada no caminhar histórico constitucional do instituto. Vê-se, nesse caso, que sempre se pode buscar em um tempo remoto institutos que lhe são análogos ou mesmo idênticos, e que, de alguma forma, acabaram por servir de inspiração ao legislador quando de sua criação. Assim, o estudo da hipótese de perda de mandato por quebra de decoro no âmbito do constitucionalismo brasileiro demonstra que sua fonte primária está fundada no direito constitucional estrangeiro, especificamente no direito estadunidense, como teremos oportunidade de explorar nas linhas que seguem. De resto, sob a ótica peculiar de nossa evolução institucional, somos obrigados também a reconhecer os caminhos que trilhou o instituto durante os diversos períodos constitucionais por qual passou nosso país. Cabe, então, retratarmos esse caminho constitucional.

\subsection{Constituição de 1824}

Iniciemos nosso trajeto pelo projeto constituinte de 1823, no qual encontramos disposição no art. 52 de que cada sala de ambos os poderes do Legislativo teria a polícia local e a do recinto de suas sessões, bem como o direito de disciplina sobre os seus membros. ${ }^{169}$ Tentava-se, com isso, indicar constitucionalmente a necessidade de regramentos das condutas

${ }^{169}$ ROURE, Agenor. A constituinte republicana. Rio de Janeiro: Imprensa Nacional, 1920, p. 455. 
parlamentares, sem, contudo, aventar a hipótese específica de perda de mandato por condutas ofensivas ao decoro, determinando apenas a competência para o regimento interno de cada uma das Casas parlamentares tratar de sua respectiva disciplina.

Prevendo o Legislativo bicameral, ${ }^{170}$ a Carta Imperial, outorgada em 25 de março de 1824, não trouxe qualquer hipótese de regramento disciplinar, por limitar-se a designar, em seu art. 21, que: "A nomeação dos respectivos Presidentes, Vice Presidentes, e Secretarios das Camaras, verificação dos poderes dos seus Membros, Juramento, e sua policia interior, se executará na fórma dos seus Regimentos”.

Sobre o Projeto de Regimento Interno da Constituinte de 1823, afirma Agenor Roure que:

$\mathrm{O}$ projecto de regimento interno d'aquella primeira Constituinte dava ao presidente da assembleia o direito de "impor silencio e advertir a qualquer deputado que commetesse excesso; e, não sendo obedecido, depois de segunda advertência, manda-lo sair do salão por aquella sessão e até prende-lo, com accordo da assembleia”. O que ficou aprovado, porém, não deu ao presidente o direito de prender o deputado e apenas o de mandá-lo sair do salão. ${ }^{171}$

Dessarte, temos que, sob a ordem constitucional de 1824, não houve referência à perda de mandato a qualquer título.

\subsection{Constituição de 1891}

Já na Constituição Republicana de 1891, fortemente inspirada no modelo constitucional estadunidense de 1787, texto que, nos dizeres de Rui Barbosa, foi "copiado traço a traço por nós", ${ }^{172}$ igualmente não há previsão de perda de mandato parlamentar por quebra de decoro. O notável é que a Constituição estadunidense prevê a cassação de mandato parlamentar por comportamento irregular em seu art. $1^{\circ}$, seção $5^{\mathrm{a}}$, competência que é dada aos próprios membros da Casa congressual a que pertencer o representante faltoso. Nesse ponto, não houve por parte do constituinte de 1891 inspiração em copiar o modelo.

\footnotetext{
170 “Art. 14. A Assembléa Geral compõe-se de duas Camaras: Camara de Deputados, e Camara de Senadores, ou Senado."

${ }^{171}$ ROURE, Agenor. A constituinte republicana, cit., p. 455.

${ }^{172}$ BARBOSA, Ruy. Comentários à Constituição federal brasileira. São Paulo: Saraiva, 1933, p. 09.
} 
Convém lembrar que, no projeto de Constituição do Governo Provisório (1889-1891), houve previsão no $\S 1^{\circ}$ do art. 18 de que: "Os regimentos internos das duas câmaras estabelecerão os meios de compelir os membros ausentes a comparecer cominando penas disciplinares". ${ }^{173} \mathrm{Na}$ discussão desse projeto, argumentou um deputado: "Sou deputado velho e nunca vi necessidade de aplicarem-se penas disciplinares a nenhum representante do Brasil". ${ }^{174}$

Por fim, o texto da Constituição estabeleceu apenas a competência para cada uma das Câmaras (Deputados e Senado) de verificação de poderes de seus membros, eleição de suas mesas, organização de seus regimentos internos, além da regulação dos serviços de suas polícias internas e da nomeação dos empregados de suas Secretarias (art. 18, parágrafo único), rechaçando a ideia de um controle disciplinar de qualquer tipo na esfera constitucional. ${ }^{175}$

Olhando para a forma como o tema dos regramentos das condutas parlamentares foi tratado nas Constituições de 1824 e 1891, podemos concluir que, quando se pensava em disciplina interna parlamentar, tinha-se em mente o controle de tumultos causados ao bom andamento dos trabalhos durante as sessões, bem como a falta de assiduidade do agente político. A moralidade da instituição estava resumida a essas duas questões no que dizia respeito à disciplina interna. Não se levantava a hipótese constitucional de expulsão do parlamentar por comportamento que contrariasse a moralidade da instituição, em termos de uma responsabilidade de ordem política assumida diante dos pares. Ruy Barbosa criticava esse modo de ver a moralidade institucional como um problema de mera assiduidade ou garantia da ocorrência das discussões parlamentares:

O escândalo, no Brasil, não está na deserção do Congresso. Está na prorrogação das sessões. Está na duplicação, já habitual, do termo assignado pela Constituição ao período legislativo. Está na renúncia de ambas as Casas do Congresso à sua autoridade constitucional. Está na absorpção da legislatura pelo Governo. Está na submissão incondicional das Câmaras ao

\footnotetext{
${ }^{173}$ ROURE, Agenor. A constituinte republicana, cit., p. 456.

${ }^{174}$ ROURE, Agenor. A constituinte republicana, cit., p. 457.

175 Apesar de não prever a cassação por quebra de decoro, a Constituição de 1891 trouxe outras hipóteses de perda de mandato no seu rol de incompatibilidades. Proibiu que membros do Congresso celebrassem contratos com o Poder Executivo, recebessem comissão ou empregos remunerados (art. 23), excetuando as missões diplomáticas, as comissões ou comandos militares e os cargos de acesso e promoções legais, prevendo, ainda, que nenhum Deputado ou Senador pudesse ser, ao mesmo tempo, Presidente ou fazer parte de bancos, companhias ou empresas que gozassem de favores do governo federal definidos em lei (art. 24). Em caso de violação de qualquer uma dessas regras, foi determinada a perda do mandato.
} 
Executivo. Esses nossos males, de que nada cogitam os moralizadores do regimen. De todos os seus requisitos funccionaes, aquelle a que menos faltam os nossos legisladores, é o da assiduidade, cuja transitória apenas envolve a inconveniência de alguns sobresaltos à administração. Tudo estaria em ter o povo representantes capazes, escrupulosos, viris; o que não supre com a mecânica da presença. ${ }^{176}$

3.3 Constituição de 1934

Em nossa Constituição de 1934, Carta que nasceu sob influência da Constituição de Weimar de 1919, ${ }^{177}$ encontramos a hipótese de perda de mandato parlamentar em seu art. 33, o qual atribui ao Tribunal Superior de Justiça Eleitoral a competência para a aplicação da pena. ${ }^{178}$ Restou silente, todavia, quanto à possibilidade de cassação por quebra de decoro. É interessante lembrar que, nas sessões da subcomissão de elaboração do anteprojeto da Constituição, ${ }^{179}$ criada por Getulio Vargas por meio do Decreto n. 21.402/32, foi proposta, durante discussão sobre as incompatibilidades parlamentares, emenda com o intuito de incluir a quebra de decoro como hipótese de perda de mandato. Estabelecia a proposta:

${ }^{176}$ BARBOSA, Ruy. Comentários à Constituição federal brasileira, cit., p. 18.

${ }^{177}$ BONAVIDES, Paulo. Curso de direito constitucional. São Paulo: Malheiros, 2008, p. 366. A Constituição de Weimar foi promulgada na Alemanha em 11 de agosto de 1919 e teve como momento político de origem o final da Primeira Guerra Mundial e a desestruturação do Império Alemão.

178 “Art. 33. Nenhum Deputado, desde a expedição do diploma, poderá:

1) celebrar contrato com a Administração Pública federal, estadual ou municipal.

2) aceitar ou exercer cargo, comissão ou emprego público remunerados, salvas as exceções previstas neste artigo e no art. 62.

$\S 1^{\circ}$ Desde que seja empossado, nenhum Deputado poderá:

1) ser diretor, proprietário ou sócio de empresa beneficiada com privilégio, isenção ou favor, em virtude de contrato com a Administração Pública;

2) ocupar cargo público, de que seja demissível ad nutum;

3) acumular um mandato com outro de caráter legislativo, federal, estadual ou municipal;

4) patrocinar causas contra a União, os Estados ou Municípios.

$\S 2^{\circ}$ É permitido ao Deputado, mediante licença prévia da Câmara, desempenhar missão diplomática, não prevalecendo neste caso o disposto no art. 34. [...]

$\S 5^{\circ}$ A infração deste artigo e seu $\S 1^{\circ}$ importa a perda do mandato, decretada pelo Tribunal Superior de Justiça Eleitoral, mediante provocação do Presidente da Câmara dos Deputados, de Deputados ou de eleitor, garantindose plena defesa ao interessado."

${ }^{179}$ Foram membros dessa subcomissão renomados juristas (grupo de notáveis), como Afrânio de Mello Franco, José Américo, Antônio Carlos Ribeiro de Andrada, João Mangabeira, Agenor de Roure, Prudente de Moraes, Arthur Ribeiro de Oliveira, Oliveira Vianna, Oswaldo Aranha, Antunes Maciel Carlos Maximiliano, Themistocles Brandão e Góes Monteiro. 
Art. O deputado cujo procedimento se tornar incompatível com a ordem ou o decoro da Assembleia poderá ter o mandato suspenso ou cassado.

$\S 1^{\circ}$ A suspensão ou cassação do mandato será proposta pelo Presidente da Assembleia, e dependerá, para se tornar effectiva, da aprovação de 3/4 dos membros presentes.

$\S 2^{\circ}$ Em caso nenhum a opinião doutrinária do deputado poderá determinar a suspensão ou cassação do seu mandato. ${ }^{180}$

Conforme já constatamos, a proposta não adentrou no texto constitucional, mas gerou intensa discussão no seio da subcomissão de elaboração do anteprojeto. Grande parte de seus membros não concordaram com a hipótese de estabelecer uma competência desse tipo ao próprio Poder Legislativo. O autor da proposta, João Mangabeira, tinha em mente situações de infidelidade partidária e, em defesa da nova hipótese de perda de mandato, alegava que quase todas as constituições do mundo armavam a mesa da Câmara desse poder. ${ }^{181}$

\subsection{Constituição de 1937}

Ao analisar a Constituição de 1937, ${ }^{182}$ observamos, em termos de arranjo institucional, que o exercício da função legislativa foi atribuído ao Parlamento Nacional, composto de Câmara dos Deputados e Conselho Federal, realizado em colaboração com o Conselho da Economia Nacional e o Presidente da República, (art. 38, $\S 1^{\circ}$ ). Importante ressaltar que não aludiu a Constituição de 1937 ao princípio da separação de poderes, nem sequer a título de fraseologia. De fato, a vestimenta constitucional do texto de 1937 era curta, ${ }^{183}$ o que

180 AZEVEDO, José Affonso Mendonça de. Elaborando a constituição nacional - atas da subcomissão elaboradora do anteprojeto 1932/1933. Edição Fac-similar. Brasília: Senado Federal, 2004, p. 170.

181 AZEVEDO, José Affonso Mendonça de. Elaborando a constituição nacional - atas da subcomissão elaboradora do anteprojeto 1932/1933, cit., p. 170.

182 Constituição conhecida como "polaca", apelido jurídico recebido por ter sido inspirada na Constituição Polonesa de 1935, outorgada durante a ditadura do Marechal Joséf Pilsudski. Convém lembrar que, conforme ressalta Loewenstein, a Constituição de 1937 tinha um caráter eclético e era perceptível muitas influências no texto elaborado por Francisco Campos: "The document is loudly ecletic. The ghost of the Weimar constitution is much in evidence in the flame of government and in the social program [...]. Other instruments of authoritarian government of contemporary Europe have served equally well, to mention only those of Austria (1934), Poland (1935), and especially Eire whose constitution of 1937 had just been submitted to a plebiscite (July, I, 1937) when Campos sat down at his desk to write the draft for his own country" (LOEWENSTEIN, Karl. Brazil under Vargas. New York: Macmillan Company, 1942, p. 123).

${ }^{183}$ Tomamos emprestado o termo de Raymundo Faoro, que, com base em escritos de Karl Loewenstein, afirmava que: “... o regime autoritário convive com a vestimenta constitucional, sem que a lei maior tenha capacidade 
demonstra a determinação de que o Presidente da República era a autoridade suprema do Estado (art. 73). ${ }^{184}$ Nesse sentido, Karl Loewenstein, em inteligente análise sobre o período, relata:

... insofar as the Estado Novo has taken a material shape the constitution is a living reality. It does not exist in so far as the functioning of the governmental institutions envisaged by the instrument is concerned. Here the only living or, if one prefers, the valid part of the constitution is the president; he is not bound by any constitutional limitations. ${ }^{185}$

No que tange à Câmara dos Deputados e ao Conselho Federal, a Constituição atribui competência para que elejam a sua mesa, organizem o seu Regimento Interno, regulem o serviço de sua polícia interna e nomeiem os funcionários de sua secretaria (art. 41). Em oposição à tradição democrático-liberal de garantir a independência de atuação do parlamentar por meio de imunidades quanto a palavras, opiniões e votos emitidos no exercício da função, a Carta de 1937 estabeleceu, nesses casos, a possibilidade de responsabilização civil e criminal (art. 43). Quanto às hipóteses de aplicação de penas disciplinares aos membros do Poder Legislativo, determinou competência à Câmara dos Deputados e ao Conselho Federal para

normativa, adulterando-se no aparente constitucionalismo - o constitucionalismo nominal, no qual a Carta Magna tem validade jurídica, mas não se adapta ao processo político, ou o constitucionalismo semântico, no qual o ordenamento jurídico apenas reconhece a situação de poder dos detentores autoritários" (FAORO, Raymundo. Os donos do poder. São Paulo: Globo, 2008, p. 829). No caso da Constituição de 1937, parece-nos que estamos diante de uma Constituição semântica: "En lugar de servir a la limitación del poder, la constitución es aqui el instrumento para estabilizar y eternizar la intervención de los dominadores fácticos de la localización del poder político" (LOEWENSTEIN, Karl. Teoría de la constitución. Barcelona: Ediciones Ariel, 1957, p. 220). Note-se que Loewenstein indica o Brasil de 1937 como um país em que ocorre o fenômeno do constitucionalismo nominal, mas aqui temos que atentar ao seguinte: os termos "constituição normativa" e "constituição nominal" dizem respeito à questão do desenvolvimento social, como nível de educação, industrialização etc., isto é, quanto mais a realidade desenvolvida se aproxima daquilo que a constituição estabelece em termos de relação política, menos a constituição é nominal e mais se afirma sua normatividade. Já a constituição semântica relaciona-se a um texto assentado para beneficiar um grupo dominante; por isso, Loewenstein afirma que esse tipo de constituição pode aparecer a qualquer tempo: "La constitución semântica, finalmente, no aparece tener ningún campo específico. Pueden surgir por doquier" (LOEWENSTEIN, Karl. Teoría de la Constitución, cit., p. 220).

${ }^{184}$ Podemos também encontrar o espírito autoritário desta Constituição nos seguintes artigos: "Art. 178. São dissolvidos nesta data a Câmara dos Deputados, o Senado Federal, as Assembleias Legislativas dos Estados e as Câmaras Municipais. As eleições ao Parlamento nacional serão marcadas pelo Presidente da República, depois de realizado o plebiscito a que se refere o art. 187. [...] Art. 180. Enquanto não se reunir o Parlamento nacional, o Presidente da República terá o poder de expedir decretos-leis sobre todas as matérias da competência legislativa da União".

185 "Na medida em que o Estado Novo assumiu uma forma material, a Constituição passa a ser uma realidade viva. Ela não existe até que o funcionamento das instituições de governo pensado pelo instrumento estejam em causa. Aqui, a única coisa viva, ou, se preferirmos, a parte válida da constituição é o presidente; ele não está vinculado por qualquer limitação constitucional." [tradução livre do autor] LOEWENSTEIN, Karl. Brazil under Vargas, cit., p. 49. 
cassarem os mandatos de seus respectivos membros nos casos de manifestação contrária à existência ou independência da nação ou incitamento à subversão violenta da ordem política ou social (art. 43, parágrafo único).

Assim, constata-se também que a Carta de 1937 não trouxe a hipótese de cassação de mandato por quebra de decoro. Com efeito, a previsão de competência para a cassação de mandato parlamentar por conduta subversiva ou contrária à existência da nação representa, considerada a conjuntura ditatorial em que se engendrou a Ordenação de 1937, a face inversa do mecanismo da cassação de mandato por quebra de decoro, instrumento típico de defesa da ordem democrática e de sua legitimidade institucional. No caso, o que temos é um instituto moralmente duvidoso constitucionalizado, instrumento de Estado de exceção.

\subsection{Constituição de 1946}

Foi a Constituição de 1946, no rol das estipulações de incompatibilidades parlamentares, que trouxe pela primeira vez a previsão de perda de mandato por quebra de decoro, estabelecendo em seu art. $48, \S 2^{\circ}$, que "perderá, igualmente, o mandato o Deputado ou Senador cujo procedimento seja reputado, pelo voto de dois terços dos membros de sua Câmara, incompatível com o decoro parlamentar".

Aquilo que o constituinte de 1891 resolveu não copiar da Constituição estadunidense de 1787, que lhe serviu inspiração à época, acabou por servir de paradigma na redação do art. 48, § $2^{\circ}$, da Constituição de 1946. Com efeito, o referido artigo fundamentou-se no art. $1^{\circ}$, seção $5^{\mathrm{a}}, \S 2^{\mathrm{o}}$, da Constituição dos Estados Unidos que, como já salientamos, prevê a competência do Legislativo para cassar mandato parlamentar quando da ocorrência de comportamentos irregulares de seus respectivos membros. ${ }^{186}$

O albergamento do instituto na Constituição de 1946 se deu pela emenda apresentada pelo Deputado Aliomar Baleeiro durante os trabalhos da constituinte. É pertinente lembrar que essa emenda, quando de sua apresentação, foi inicialmente rejeitada pela Comissão de

${ }^{186}$ Dispõe o art. $1^{\text {o }}$, seção $5^{\text {a }}, \S 2^{\text {o }}$, da Constituição dos Estados Unidos: "Each House may determine the rules of its proceedings, punish its members for disorderly Behavior, and, with the concurrence of two-thirds, expel a member". 
Constituição, ${ }^{187}$ isto é, mais uma vez tendia o constituinte a não prever tal tipo de estipulação no texto constitucional. Ocorreu, todavia, que logo após a rejeição do projeto, situações constrangedoras envolvendo um membro do parlamento, o Deputado Barreto Pinto, ${ }^{188}$ levaram o Deputado Aliomar Baleeiro a reapresentar a emenda que acabou por ser aprovada e incorporada à Constituição.

Surpreendente é o fato de que a primeira aplicação do instituto da cassação por quebra de decoro e única sob a vigência da Constituição de 1946, que viria a ser exterminada com o golpe de 1964, liga-se exatamente aos fatos que levaram à sua introdução no ordenamento constitucional. Explica-se: o primeiro parlamentar cassado por quebra de decoro no País foi o Deputado Barreto Pinto (PTB) em 1949, episódio que ficou conhecido como o "Caso da cueca”. O mesmo deputado que havia dado motivos para a introdução do instituto da cassação por quebra de decoro na Constituição de 1946 foi o primeiro parlamentar cassado por esse motivo.

Na Constituição de 1946, não houve competência alguma para os regimentos internos criarem outros tipos de penalidades, ou seja, sendo o procedimento indecoroso, restava aos pares apenas a opção pela cassação ou absolvição, não havendo hipóteses gradativas de pena.

É preciso lembrar que a cassação de mandato com base no $\S 2^{\circ}$ do art. 48 da Constituição de 1946 não implicava inelegibilidade, seguindo, nesse ponto, a perspectiva da Constituição estadunidense de 1787. Com efeito, o parlamentar cassado por quebra de decoro podia ser reeleito e voltar a exercer a função sem maiores problemas, o que acabou acontecendo, por exemplo, com Deputado Barreto Pinto. ${ }^{189}$

${ }^{187}$ Diário do Congresso Nacional (1949), Congresso Nacional, Distrito Federal, p. 4.835.

188 O Deputado Edmundo Barreto Pinto, em 29 de junho de 1946, concedeu entrevista polêmica à revista $O$ Cruzeiro com a seguinte manchete: "Barreto Pinto sem máscara", deixando-se fotografar de casacas e cuecas deitado em uma banheira. Foi a partir desse acontecimento que Aliomar Baleeiro reapresentou a emenda que incluía o $\S 2^{\circ}$ ao art. 48 da Constituição de 1946, consoante podemos inferir do Relatório apresentado por Freitas e Castro no processo que deu ensejo à Resolução que cassou o mandato de Barreto Pinto em 1949 (Diário do Congresso Nacional (1949), Congresso Nacional, Distrito Federal, p. 4.385).

189 TEIXEIRA, Carla Costa. A honra da política. Rio de Janeiro: Relume Dumará, 1998, p. 87. 


\subsection{Constituição de 1964}

Produto de um coup d'État ${ }^{190}$ levado a efeito em 1964, nossa Carta Política de 1967, que tinha por objetivo legitimar e institucionalizar o movimento que derrubará os alicerces democráticos da Constituição de 1946, ${ }^{191}$ manteve em seu art. 37, II, a hipótese de cassação de mandato por procedimento que for declarado incompatível com o decoro parlamentar, determinando ainda em seu $\S 1^{\circ}$ que a perda do mandato fosse declarada, em votação secreta, por dois terços da Câmara dos Deputados ou do Senado Federal, mediante provocação de qualquer de seus membros, da respectiva mesa ou de partido político.

\subsection{Emenda Constitucional 01/69}

A Emenda Constitucional n. 01, promulgada em 17 de outubro de 1969, considerada por alguns doutrinadores a outorga de um novo texto constitucional em relação ao texto de $1967,{ }^{192}$ trouxe mudanças no que se refere à cassação de mandato por quebra de decoro. Em seu art. 35, II, previu que perdesse o mandato o Deputado ou Senador cujo procedimento for declarado incompatível com o decoro parlamentar ou atentatório das instituições vigentes.

Como se vê, ao lado da hipótese de cassação de mandato por conduta indecorosa, situação já prevista nas Cartas de 1946 e 1967, trouxe a Emenda Constitucional n. 01/69 uma nova hipótese: o procedimento atentatório das instituições vigentes.

Em suas análises, bem observou Manoel Gonçalves Ferreira Filho que essa nova hipótese aventada pelo art. 35, II, encontra sua fonte inspiradora no art. 43, parágrafo único, da

${ }^{190}$ Golpe de Estado.

191 BONAVIDES, Paulo; ANDRADE, Paes de. História constitucional do Brasil. Brasília: Paz e Terra, 1989, p. 431 .

${ }^{192}$ Entendimento de José Afonso da Silva (Curso de direito constitucional positivo. São Paulo: Malheiros, 2007, p. 87) e Oswaldo Aranha Bandeira de Mello (Princípios gerais de direito administrativo. São Paulo: Malheiros, 2007. v. I, p. 571). Ao contrário, temos a posição de Pontes de Miranda, que comenta a Constituição de 1967 sob a perspectiva das mudanças trazidas pela Emenda n. 01/69 (Comentários à Constituição de 1967, com a Emenda n. 01 de 1969. São Paulo: Revista dos Tribunais, 1970). Ainda a respeito da questão, Paulo Bonavides e Paes de Andrade nos lembram que: "O poder de revisão ou de emenda limitado é parcial, e também com esse fundamento jurídico o Supremo Tribunal Federal decidiu reconhecer por unanimidade que a vigência era a da Carta de 1967, e não da Emenda n. 1 de 1969" (BONAVIDES, Paulo; ANDRADE, Paes de. História constitucional do Brasil, cit., p. 444). 
Constituição de 1937, dispositivo que previa a perda do mandato em razão de "manifestação contrária à existência ou independência da Nação ou incitamento à subversão violenta da ordem política ou social", aduzindo ainda o eminente jurista que "literalmente interpretado, o preceito em exame é mais amplo do que o de 1937". ${ }^{193}$ Como já tivemos oportunidade de analisar quando tratamos do instituto da cassação de mandato na Carta de 1937, trata-se aqui de um instituto que se afasta em seu objetivo político da hipótese de perda de mandato por comportamento incompatível com o decoro parlamentar. Considerando todo o enredo histórico jurídico e político que envolveu o advento da Constituição de 1964 e a Emenda Constitucional n. 01 de 1969, conclui-se que a previsão de expulsão de membro parlamentar por atos atentatórios às instituições vigentes constitui mecanismo coercitivo passível a toda evidência de ser usado contra a atuação parlamentar legitíma e democrática. Nesses termos, Manoel Gonçalves Ferreira Filho assevera que "o conceito de atentado às instituições vigentes não é preciso, de modo que pode ser interpretado com grande latitude, em prejuízo da independência parlamentar". 194

Ademais, devemos verificar que o art. $35, \S 1^{\circ}$, estipulou que, "além de outros casos definidos no regimento interno, considerar-se-á incompatível com o decoro parlamentar o abuso das prerrogativas asseguradas ao congressista ou a percepção, no exercício do mandato, de vantagens ilícitas ou imorais". A interpretação que pode ser dada a respeito desse parágrafo é a definição, de forma mais ou menos rígida, do que vem a ser falta de decoro parlamentar. Além disso, conferiu certo grau de determinação a um conceito que, por regra, guarda alto grau de indeterminação. Nesse particular, a Constituição teria adotado um critério criminal para a definição da conduta; ${ }^{195}$ assim, caso a ofensa não se enquadre nesses ditames constitucionais, mesmo que se trate de um escândalo e cause uma grande reprovação pública, o parlamentar faltoso não pode ser cassado por esse motivo, isto é, não bastaria a comoção pública ou a mera maculação da imagem do Poder Legislativo, mas seria necessário um enquadramento nas hipóteses normativamente previstas. Por óbvio, não se trata exatamente de um critério criminal de tipificação, já que não pormenoriza uma conduta de forma objetiva a não dar grande margem a interpretações; pelo contrário, é uma tipificação calculada para que seja sempre passível certo nível interpretativo.

\footnotetext{
${ }^{193}$ FILHO, Manoel Gonçalves Ferreira. Comentários à Constituição brasileira. São Paulo: Saraiva, 1984, p. 209.

${ }^{194}$ FILHO, Manoel Gonçalves Ferreira. Comentários à Constituição brasileira, cit., p. 209.

${ }^{195}$ FILHO, Manoel Gonçalves Ferreira. Comentários à Constituição brasileira, cit., p. 212.
} 
No que se refere à competência para decidir sobre a cassação, o texto constitucional determinou em seu $\S 2^{\circ}$ que a perda do mandato seria declarada pela Câmara dos Deputados ou pelo Senado Federal, mediante provocação de qualquer de seus membros, da respectiva mesa ou de partido político. Observe-se que não houve indicação, decerto propositadamente, do quórum qualificado para a cassação, que nas Constituições de 1946 e 1967 era de dois terços dos membros da respectiva Casa parlamentar ofendida. Isso não impediu Pontes de Miranda, ao interpretar o referido artigo, de manter o posicionamento da necessidade de quórum de dois terços para a validade da cassação. ${ }^{196}$

Como veremos, o quórum qualificado perfaz uma garantia individual do parlamentar. Ademais, outro ponto que chama a atenção é o fato de que não houve a previsão de votação secreta no procedimento que decide pela cassação, o que, em um regime autoritário, representa uma ameaça à instituição parlamentar.

${ }^{196}$ MIRANDA, Pontes de. Comentários à constituição de 1967, com a Emenda n. 01 de 1969, cit., p. 39. 
PARTE II

DO PROCESSO DE CASSAÇÃO DE MANDATO PARLAMENTAR POR QUEBRA DE DECORO

\section{CAPÍTULO 4 - FINALIDADE E NATUREZA JURÍDICA DO PROCESSO DE CASSAÇÃO}

O mecanismo constitucional da cassação de mandato por quebra de decoro, nos termos do art. 55, II, da Carta Republicana de 1988, configura, prima facie, um instrumento repressivo aplicado ao representante político cuja conduta ofenda a honorabilidade e a dignidade do Poder Legislativo. Nesses termos, duas perspectivas analíticas surgem. A primeira aponta para o próprio instrumento, sua natureza, suas regras de aplicabilidade, seu modo de funcionamento; enfim, salienta-se o procedimento normativo em si. Já na segunda perspectiva podemos lançar nosso olhar não tanto em direção ao procedimento, mas para o seu objeto e seu sentido de finalidade, ilustrando os motivos determinantes que impõem seu reconhecimento no plano normativo e sua importância. São essas duas perspectivas essenciais e complementares; trata-se de falar dos meios (instrumento) e dos fins. É esta a proposta de desenvolvimento do presente capítulo, central em nosso estudo.

\subsection{Finalidade}

A cassação de mandato por quebra de decoro parlamentar é um mecanismo de depuração institucional, na medida em que sua aplicação leva ao desfazimento da relação de representação política, com a expulsão do membro cuja conduta não esteja à altura dos valores institucionais consagrados constitucionalmente. Reafirme-se, então, que a teleologia do instituto está na manutenção da imagem de alto valor e prestígio do Parlamento (honra objetiva) perante a sociedade. É nesse caráter protetivo institucional que encontramos, sem dúvida, de forma imediata, o bem jurídico tutelado pelo instituto, a moralidade institucional. Todavia, com essa visão não se elucida todos os contornos de importância do instituto. É preciso perguntar: por que se deve tomar o prestígio e a dignidade do Parlamento como bem a 
ser protegido? Qual o efeito da violação da moralidade pública perpetrada por agente político parlamentar?

De fato, podemos iniciar nosso raciocínio decifrando aspectos relevantes que rondam a ideia de instituição política estatal. Partamos, então, da seguinte pressuposição, a de que quanto mais o poder estatal institucionalizado tem capacidade de depuração, no sentido de retirar de seus meios aqueles cuja reputação junto aos cidadãos está maculada, maiores são as possibilidades do exercício legítimo desse poder. ${ }^{197}$ Legitimidade e responsabilidade são, nesses termos, faces do mesmo fenômeno. ${ }^{198} \mathrm{O}$ representante político parlamentar é aquele que responde (é responsável) por seus atos, ordinariamente presta contas diante do "povo" no momento eleitoral, efeito inconteste do princípio democrático liberal. A previsão constitucional do instituto da cassação de mandatos por quebra de decoro segue a mesma lógica, embora não em caráter ordinário, mas em regime de excepcionalidade, o representante parlamentar responde frente a seus pares na respectiva Casa legislativa a que pertence pelo procedimento ofensivo à moral institucional.

Com efeito, temos que a cassação de mandato por quebra de decoro é instrumento de proteção da legitimidade institucional democrática, e a sua essencialidade aqui é em relação a todo ordenamento constitucional.

Nessa linha argumentativa, Dennis Thompson, com propriedade, afirma que: "The primary purpose of legislative ethics is to sustain institutional conditions in the legislature that promote the integrity of the democratic process". ${ }^{199}$ Deve-se entender, então, que o albergamento do instituto da cassação de mandato por quebra de decoro em nosso texto constitucional de 1988 encontra sua razão de ser no plano avaliativo político, ou seja, é constitucionalmente considerado porque politicamente necessário.

\footnotetext{
${ }^{197}$ É essa uma lição antiga, e notará Montesquieu em seu $O$ espírito das leis que: "Quando diversos corpos legislativos sucedem uns aos outros, o povo, que tem uma má opinião do corpo legislativo atual, coloca, com razão, suas esperanças naquele que virá depois. Mas se fosse sempre o mesmo corpo, o povo, vendo-o uma vez corrompido, não esperaria mais nada de suas leis; tornar-se-ia furioso ou cairia na indolência” (MONTESQUIEU, Charles-Louis de Secondat. O espírito das leis. São Paulo: Martins Fontes, 2005, p. 173).

${ }^{198}$ ENTERRÍA, Eduardo Garcia. El principio de "la responsabilidad de los poderes públicos" según el art. 9.3 de la Constittución y la responsabilidad patrimonial del estado legislador. Revista Española de Derecho Constitucional. Madrid, año 23, n. 67, enero/abr. 2003, p. 37.

199 "O objetivo principal da ética legislativa é sustentar as condições institucionais na legislatura que favoreçam a integridade do processo democrático." [tradução livre do autor] THOMPSON, Dennis F. Ethics in congress: from individual to institutional corruption. Washington: The Brookings Institution, 1995, p. 19.
} 
No entanto, conforme ora exposto, tem-se o resultado da análise sem a devida pormenorização do processo que se quer evidenciar.

As instituições políticas, isto é, aquelas inseridas no âmbito do Estado Moderno, perfazem um aparato governamental por meio do qual se exerce o poder, ${ }^{200}$ por isso, é comum dizer-se, com certa razoabilidade, que o que é passível de ser tomado politicamente não é propriamente o poder do Estado, atributo inerente ao seu domínio, mas os instrumentos que possibilitam o exercício desse poder, entendendo-se por instrumento instituições. ${ }^{201}$ Nesses termos, Jorge Miranda afirma que "o poder não é tanto da comunidade estadual quanto do aparelho de órgãos e serviços que dentro desta se salientam". ${ }^{202}$

Entretanto, o poder estatal em sua efetividade institucional, enquanto poder real que se exerce $^{203}$ de forma estável na vida concreta, deve tender a alcançar um nível de reconhecimento social como autoridade legítima, como um poder que obriga moralmente aqueles que vão receber seus influxos. ${ }^{204} \mathrm{O}$ exercício do poder por meio das instituições políticas não pode ser sentido nem visto primariamente como coação ou força. Nesse sentido, disserta Maurice Duverger que: "El poder siempre busca ser aceptado: es más, desea hacerce amar y reverenciar por intermédio de los sistemas de creencias". ${ }^{205} \mathrm{O}$ poder político estatal não deve realizar-se como um mero poder de fato, realidade inequívoca de quem detém e exerce o mando político, mas também como um poder simbólico, que induz respeito e consideração subjetiva dos destinatários do poder. A esse respeito, Rousseau perspicazmente afirmava que: "O mais forte nunca é o bastante forte para ser sempre senhor, se não transformar sua força em direito e a obediência em dever". ${ }^{206}$ É segundo esse parâmetro que a análise weberiana tenta responder à questão da obediência ao Estado, concluindo que:

... o Estado moderno é um agrupamento de dominação que apresenta caráter institucional e que procurou (com êxito) monopolizar, nos limites de um território, a violência física legítima como

\footnotetext{
${ }^{200}$ LOEWENSTEIN, Karl. Teoría de la constitución. Barcelona: Ariel, 1957, p. 30.

${ }^{201}$ DUSSEL, Enrique. 20 teses de política. São Paulo: Clasco, 2007, p. 31.

${ }^{202}$ MIRANDA, Jorge. Teoria do Estado e da constituição. Rio de Janeiro: Forense, 2003, p. 218.

${ }^{203}$ SARTORI, Giovanni. Ingeniería constitucional comparada. México: Fondo de Cultura Económica, 2005, p. 159.

${ }^{204}$ HELLER, Herman. Teoria do Estado. São Paulo: Mestre Jou, 1968, p. 261.

205 "O poder sempre procura ser aceito: na verdade, deseja fazer-se amado e reverenciado através dos sistemas de crenças.” [tradução livre do autor] DUVERGER, Maurice. Métodos de las ciencias sociales. Barcelona: Ariel, 1980 , p. 523.

${ }^{206}$ ROUSSEAU, Jean-Jacques. O contrato social: princípios do direito político. São Paulo: Martins Fontes, 2006, p. 12.
} 
instrumento de domínio e que, tendo esse objetivo, reuniu nas mãos dos dirigentes os meios materiais de gestão. ${ }^{207}$

Defrontamo-nos, assim, com a oposição: exercício de poder legítimo e ilegítimo. No primeiro caso, aqueles que obedecem, ou melhor, os destinatários do poder, estão aptos a reconhecer que se submetem a uma autoridade legítima, que têm um dever a cumprir porque legítima a autoridade. Já no caso da ilegitimidade do poder, ocorre o que Pinto Ferreira nomeou como perversão, "o poder ilegítimo é o poder externo, pervertido, em geral imposto pela violência". ${ }^{208}$ Nesses termos, o poder pervertido, enquanto faceta da ilegitimidade, se traduz no exercício do poder inapto a encontrar um ambiente socialmente propício à recepção de seus comandos, logo se vendo obrigado a utilizar cada vez mais de meios coercitivos para impor obediência. O efeito é dedutível: um círculo vicioso que faz com que o exercício do poder seja identificado de forma contínua como pura força, uma mera vis dominationes.

Com efeito, o poder estatal institucionalizado na busca por certo grau de legitimação deve alcançar uma aparência oposta àquela do déspota caprichoso descrito por Montesquieu, que é um exemplo perfeito do exercício do poder em forma pervertida e ilegítima:

\begin{abstract}
Um governo moderado pode, tanto quanto quiser, e sem perigo, soltar as rédeas. Mantém-se pelas leis e pela força. Mas, quando, num governo despótico, o príncipe cessa por um momento de erguer o braço; quando não pode destruir imediatamente aqueles que possuem os primeiros lugares, tudo está perdido: como o motor do governo, que é o temor, não existe mais, o povo não tem mais protetor. [...] Nos Estados despóticos, a natureza do governo requer uma extrema obediência [...]. Não há temperamento, modificação, acomodamentos, termos, equivalentes, nada de igual ou de melhor para propor; o homem é uma criatura que obedece a outra a criatura que quer. [...] Ali a parte do homem, como a dos animais, é o instinto, a obediência, o castigo. ${ }^{209}$
\end{abstract}

Em oposição a essa imagem, o exercício do poder estatal legítimo está calcado em uma qualidade de consenso representada na constância das "práticas sociais",210 de dominação que configuram a própria existência efetiva das instituições políticas. Sabemos que uma instituição

\footnotetext{
${ }^{207}$ WEBER, Max. Ciência e política - duas vocações. São Paulo: Cultrix, 1983, p. 62.

${ }^{208}$ FERREIRA, Pinto. Teoria geral do Estado. São Paulo: Saraiva, 1975. v. I, p. 357.

${ }^{209}$ MONTESQUIEU, Charles-Louis de Secondat. O espírito das leis, cit., p. 39-40.

${ }^{210}$ RAWLS, Jhon. Uma teoria da justiça. São Paulo: Martins Fontes, 2008, p. 66.
} 
política existe efetivamente porque as práticas sociais assim nos indicam; cabe, então, procurar nessa efetividade institucional o grau de consenso determinante da legitimidade do poder. Esse consenso é, conforme posição de Maurice Duverger, o acordo que existe "en una sociedad dada sobres sus estructuras, su jerarquia, su orientacíon etc.; el acuerdo sobre la autoridad, sobre el gobierno, sobre el poder, es edentemente uno de los elementos fundamentales del consensus". ${ }^{211}$ Nesse sentido, diz-se que "as instituições repousam, na verdade, não sobre acordos fáticos, mas sobre suposições comuns a respeito da expectativa comum dos outros". ${ }^{212}$ Esse consenso a respeito da legitimidade do poder político maximiza as próprias potencialidades do sistema de dominação, possibilitando estabilidade e equilíbrio, ${ }^{213}$ bem como prevenindo tensões entre governantes e governados. ${ }^{214}$

Não é o caso de explorarmos em minúcias a gênese do poder político estatal e a raiz polêmica de sua legitimidade, tema repleto de controvérsias, mas apenas constatar que, uma vez ocorrida a distinção entre detentores do poder político e os destinatários do poder, isto é, entre governantes e governados, a questão da legitimidade do exercício do poder coloca-se de modo inarredável. Aqueles que obedecem devem se perguntar por que obedecer. Da perspectiva do poder, trata-se, pois, de buscar uma "justificação-explicação de uma ordem de domínio (estrutura de domínio). ${ }^{215}$ Isso porque não há uma identidade concreta entre sujeitos de mando e de obediência, como se a vida coletiva fosse, ao mesmo tempo, a vida política, no sentido do zoon politikón aristotélico. ${ }^{216}$

\footnotetext{
211 “ em uma dada sociedade, sobre suas estruturas, sua hierarquia, sua orientação etc,; o acordo sobre a autoridade, sobre o governo, sobre o poder, é evidentemente um dos elementos fundamentais de consenso." [tradução livre do autor] DUVERGER, Maurice. Métodos de las ciencias sociales, cit., p. 524.

${ }^{212}$ FERRAZ JR. Tércio Sampaio. Introdução ao estudo do Direito: técnica, decisão, dominação. São Paulo: Atlas, 2007, p. 109. No mesmo sentido, ver SARTORI, Giovanni. Teoria da democracia revisitada. O debate contemporâneo. São Paulo: Ática, 1994, p. 128.

${ }^{213}$ FARIA, José Eduardo. Poder e legitimidade. São Paulo: Perspectiva, 1978, p. 112.

${ }^{214}$ Essa análise da instituição estatal enquanto exercício concreto do poder e de sua legitimidade aproxima-se da distinção entre potestas e auctoritas, exposta por Carl Schmitt: “... al Poder (siempre efectivo por necesida) le corresponden conceptos como soberanía y majestad; autoridad, por el contrario, significa un prestigio esencialmente basado en el elemento de la continuidad y contiene una referencia a la tradición y permanência. Ambas cosas, fuerza y autoridad, son eficaces y vivas, una junto a outra, en todo Estado. La contraposición clásica se encuentra también para esto en el Derecho político de Roma: el Senado tênia auctoritas; del Pueblo, por el contrario, se desprenden potestas e imperium" (Teoria de la constitución. Madrid: Alianza Universidad, 2009, p. 93).

${ }^{215}$ CANOTILHO, José Joaquim Gomes. Constituição dirigente e vinculação do legislador. Coimbra: Coimbra Editora, 2001, p. 15.

${ }^{216}$ SARTORI, Giovanni. A política. Brasília: Editora da UnB, 1997, p. 158.
} 
Com isso, coloca-se a questão da legitimidade do exercício do poder nos escaninhos da história da ascensão política da burguesia a partir do séc. XVI, pois é precisamente nesse momento em que podem ser observadas de forma mais nítida as representações da dimensão econômica da vida como ambiente das relações privadas individuais, apartada da política, enquanto esfera do domínio público estatal. Nessa ordem de ideias, o fenômeno está posto para a nossa análise, qual seja, "o problema da legitimidade nasce, justamente, quando o governo das comunidades antigas deixa de ser direto - nas quais os cidadãos governam-se eles próprios - e passa a intermediário - como é o caso dos regimes representativos". ${ }^{217}$

Importa, então, constatar que, nos Estados constitucionais contemporâneos, a legitimidade institucional está fundada precipuamente no que os teóricos em geral chamam de consenso democrático ${ }^{218}$ - algumas de suas características foram ditadas no Capítulo 1 deste trabalho.

Devemos compreender que o emaranhado de crenças, regras e práticas compartilhadas pela sociedade ocidental contemporânea giram em torno da qualidade democrática; acreditase, de modo geral, que a democracia é a melhor forma de governo, e isso é tomado como um ponto de partida dado, um pressuposto para qualquer discussão ulterior no campo político ou jurídico. ${ }^{219}$ Consubstancia um fator tão importante para o exercício do poder, que "mesmo os ditadores mais repressivos geralmente se dizem favoráveis, hoje em dia, ao legítimo direito do povo de participar no governo...."220

O Poder Legislativo, refletindo sobre o fenômeno do poder estatal, está imbuído de toda essa sistemática de exercício do poder e legitimação institucional que se estabelece dinamicamente em relações complexas, que envolvem os agentes políticos incumbidos de missão institucional parlamentar e o povo, destinatário do poder, que recebe os comandos estatais e, ao mesmo tempo, julga os governantes mediante os processos eleitorais.

\footnotetext{
${ }^{217}$ FARIA, José Eduardo. Poder e legitimidade, cit., p. 62.

${ }^{218} \mathrm{Na}$ visão de Sartori, não devemos compreender o consenso democrático como uma simples aceitação passiva do poder, mas como um "compartilhar" que vincula. Sobre esse compartilhar, afirma: "Em relação à teoria da democracia existem pelo menos três objetos passíveis de partilha: a) valores supremos (tais como liberdade e igualdade); b) regras do jogo, ou procedimentos; e c) governos específicos e políticas governamentais" (SARTORI, Giovanni. Teoria da democracia revisitada, cit., p. 128).

${ }^{219}$ Neste sentido, John Ferejohn pode afirmar que: "We take for granted that modern government must be democratic in the sense of deriving its authority directly or indirectly from de people" (Accountability and authority: toward a theory of political accountability. In: MANIN, Bernard; PRZEWORSKI, Adam; STOKES, Susan C. Democracy, accoutability and representation. Cambridge: Cambridge University Press, 2003, p. 131). ${ }^{220}$ DAHL, Robert. Poliarquia: participação e oposição. São Paulo: Edusp, 1997, p. 28.
} 
A questão do decoro parlamentar está intimamente ligada à legitimidade institucional democrática, ao próprio consenso que leva os órgãos máximos de poder estatal a serem reconhecidos como legítimos diante dos governados. Com isso, não afirmamos que o fenômeno da legitimidade e do decoro possam ser reduzidos um ao outro, pois não basta que um poder seja ético do ponto de vista da sociedade para ser legítimo, mas, sim, que tanto o decoro parlamentar quanto a moralidade administrativa são elementos fundamentais na construção da legitimidade institucional dos poderes do Estado.

Ao tratar do tema da moralidade aplicada à Administração Pública, Cármem Lúcia Antunes Rocha realiza análise que serve, na mesma medida, ao decoro aplicável ao Poder Legislativo:

A moralidade administrativa legitima o comportamento da Administração Pública, elaborada como ela é por um Direito nascido do próprio povo. Por isso, é o acatamento da moralidade administrativa, como princípio de Direito que dota o sistema de legitimidade, o que se estende à qualificação legítima do Poder do Estado. O que se põe em foco, quando se cuida de moralidade administrativa, é a confiança do povo no Poder institucionalizado e a legitimidade de seu desempenho quanto à gestão da coisa pública. ${ }^{221}$

E conclui que:

A ruptura ou afronta a este princípio, que transparece em qualquer comportamento público, agride o sentimento de Justiça de um povo e coloca sob o brasão de desconfiança não apenas o ato praticado pelo agente, e que configure um comportamento imoral, mas a Administração Pública e o próprio Estado, que se vê questionado em sua própria justificativa. ${ }^{22}$

Isso nos leva a perceber o pressuposto da atuação decorosa do parlamentar como um requisito de efetividade da própria democracia representativa, já que a legitimidade institucional se realiza sempre por meio do povo, o qual requer de seus representantes políticos comportamentos dignos com os deveres a serem cumpridos. Geovanni Sartori, tratando especificamente dos problemas enfrentados no ambiente político democrático contemporâneo, é preciso, ao determinar que "El descontento con los partidos y la perdida de

${ }^{221}$ ROCHA, Cármen Lúcia Antunes. Princípios constitucionais da administração pública. Belo Horizonte: Del Rey, 1994, p. 191.

${ }^{222}$ ROCHA, Cármen Lúcia Antunes. Princípios constitucionais da administração pública, cit., p. 208. 
prestigio de los políticos se reflejan inevitablemente en las instituciones de las que son miembros. Si se llega a considerar que las próprias instituciones son instrumentos inadecuados de la democracia, entonces salvar a la política se convierte en una tarea muy difícil". ${ }^{223}$

Significativo, nesse sentido, é o posicionamento do Ministro Celso de Mello, ao analisar o inevitável reflexo da conduta parlamentar indecorosa na honra objetiva das instituições democráticas:

\begin{abstract}
Qualquer ato de ofensa ao decoro parlamentar culmina por atingir, injustamente, a própria respeitabilidade institucional do Poder Legislativo, residindo, nesse ponto, a legitimidade éticojurídica do procedimento constitucional de cassação do mandato parlamentar, em ordem a excluir, da comunhão dos legisladores, aquele - qualquer que seja - que se haja mostrado indigno do desempenho da magna função de representar o Povo, de formular a legislação da República e de controlar as instâncias" (STF, MS 24.458/DF, Rel. Min. Celso de Mello, DJ de 18.02.2003).
\end{abstract}

Como bem salienta o eminente Ministro no trecho do acórdão ora transcrito, a legitimação ético-jurídica do procedimento de cassação de mandato por quebra de decoro encontra-se precisamente na necessidade de manutenção da respeitabilidade institucional. Leia-se, então, que poder não respeitado é poder ameaçado quanto ao seu exercício. A relação existente entre governantes e governados nas democracias constitucionais contemporâneas é de dependência dos primeiros em relação aos segundos, que passam sob o crivo periódico dos processos eleitorais. A opinião pública é o lugar do consenso, o qual, conforme os ensinamentos de Monica Herman Salem Caggiano, "traduz a máxima identificação dos governantes com os governados, ponto-chave dos regimes democráticos"; ${ }^{224}$ assim, ao minar a confiança do povo por questões de decoro e moralidade de seus membros, o Poder Legislativo vê ameaçada sua efetividade institucional.

Nessa altura, é imperioso atentar para o fato de que a imoralidade pública e a falta de decoro parlamentar colocam-nos diante do intrincado tema da corrupção. Etimologicamente, a palavra "corrupção" tem sua raiz no latim corrumpere, que traz o sentido de rompimento,

\footnotetext{
223 "O descontentamento com os partidos e a perda de prestígio dos políticos se refletem inevitavelmente nas instituições de que são membros. Se chega-se a considerar que as próprias instituições são instrumentos inadequados da democracia, então salvar a política se converte em uma tarefa muito difícil." [tradução livre do autor] SARTORI, Giovanni. Ingeniería constitucional comparada, cit., p. 164.

${ }^{224}$ CAGGIANO, Mônica Herman Salem. Oposição na política. São Paulo: Angelotti, 1995, p. 56.
} 
deterioração e decadência, não vinculada somente à questão corporal ou material mas também espiritual e moral. ${ }^{225}$ No cotidiano, atualmente, utilizamos a palavra tão somente para o campo público. A corrupção seria, por excelência, a representação mais escandalosa da imoralidade do agente público, especificamente do representante político. A corrupção evidencia, em sua ocorrência, o maior grau de inaptidão moral do agente político e o maior nível de reprovação pública.

Em regra, quando imaginamos o ato corrupto, tendemos a considerá-lo uma "conduta de autoridade que exerce o poder de modo indevido, em benefício de interesse privado, em troca de uma retribuição de ordem material". ${ }^{226}$ Nesse sentido, a palavra corrupção perderia sua generalidade, enquanto termo ligado à deterioração moral no campo público, ganhando uma tipologia mais específica, como uma violação de regras públicas para benefício particular em troca de ganhos materiais. Essa tem sido a forma com que os analistas têm interpretado a corrupção nos Estados constitucionais. Com efeito, observa Dennis F. Thompson que:

In the tradition of political theory, corruption is a disease of the body politic. Like virus invading the physical body, hostile forces spread through the political body, enfeebling the spirit of the laws and undermining the principles of the regime. [...] In regimes of a more popular cast, such as republics and democracies, the virus shows itself as private interests. Its agents are greedy individuals, contentious factions, and mass movements that seek to control collective authority for their own purposes. The essence of corruption in this conception is the pollution of the public by the private. ${ }^{227}$

Com isso, temos que, quando o cidadão visualiza no Estado uma instituição tomada por sujeitos, agindo de forma privada em defesa de particularismos, a identidade, leia-se identificação entre o povo e os detentores do poder, corre o risco de se tornar uma oposição, e nenhum poder político pode se efetivar de forma legítima e estável nesse contexto.

${ }^{225}$ TORRINHA, Francisco. Dicionário português-latino. Porto: Editorial Domingos Barreira, 1939, p. 329.

${ }^{226}$ FERREIRA FILHO, Manoel Gonçalves. A corrupção como fenômeno social e político. Revista de Direito Administrativo. Rio de Janeiro, jul./set. 1991, p. 03. Ver também THOMPSON, John B. O escândalo político: poder e visibilidade na era da mídia. Petrópolis: Vozes, 2002, p. 56.

227 "Na tradição da teoria política, corrupção é uma doença do corpo político. Assim como o vírus invade o corpo físico, forças adversas se espalham pelo corpo político, enfraquecendo o espírito das leis e minando os princípios do regime [...]. Em regimes de matriz mais popular, como são as repúblicas e as democracias, o vírus se apresenta como interesses privados. Seus agentes são indivíduos gananciosos, facções controversas e movimentos de massa que procuram controlar a autoridade coletiva para o cumprimento de seus próprios propósitos. A essência da corrupção, nesse sentido, é a confusão entre o público e o privado." [tradução livre do autor] THOMPSON, Dennis F. Ethics in congress: from individual to institutional corruption, cit., p. 28. 
Feitas essas considerações, é importante observar que, quando falamos em imoralidade pública ou falta de decoro parlamentar, ambas as ocorrências não podem ser reduzidas ao sentido de corrupção do modo como expomos anteriormente, primeiro porque o conceito constitucional está focado na ideia de moralidade pública (art. 37, caput, da Constituição Federal) e de decoro (art. 55, II, da Constituição Federal), ambas as ideias de caráter amplo, e, segundo, pois nem sempre a imoralidade ameaçadora da legitimidade institucional se perfaz em uma situação de ganhos materiais particulares de agentes públicos em detrimento de interesse coletivo. No caso do procedimento ofensivo à dignidade parlamentar, podem ocorrer fatos vinculados a outras esferas da vida, tais como religiosa, sexual e familiar, que, pelo contexto em que se inserem e pelos agentes que envolvem, acabam por resvalar no campo político, dando ensejo a uma reprovação pública que atinge a integridade institucional. ${ }^{228}$

Dessa maneira, a questão do decoro parlamentar, assim como a da moralidade administrativa, impõe ao legislador a construção, na esfera do ordenamento jurídico de mecanismos de controle dos agentes políticos, melhor dizendo, coloca-se a questão da qualidade dos sistemas jurídicos e da capacidade que eles têm, diante de determinada realidade, de impedir e prevenir os comportamentos políticos indesejáveis sob o ângulo dos governados, garantindo o máximo de solidez e aceitação do sistema político.

A ideia básica é a de que o ordenamento jurídico regule a atuação no Parlamento de modo que os seus membros tendam a cumprir as finalidades que são inerentes à instituição. A possibilidade de construção de contenções que limitam a atuação do agente político parlamentar se dá pelo simples fato de que instituições políticas estão sempre determinadas por "um sistema de normas que define cargos e funções com seus direitos e deveres, poderes e imunidades etc. Essas normas especificam que certas formas de ação são permissíveis e outras, proibidas; e estipula certas penalidades e defesa". ${ }^{229}$ No caso do Poder Legislativo, a Constituição assume uma posição de destaque, pois é nela em que se encontram as competências dos órgãos superiores do Estado (Legislativo, Executivo e Judiciário).

$\mathrm{Na}$ esteira desse raciocínio, conclui-se que, quando o ordenamento constitucional prevê uma competência de avaliação e punição à violação das regras de decoro parlamentar, como o faz a nossa Carta Republicana de 1988 em seu art. 55, II, o objetivo de aplicabilidade dessa

\footnotetext{
${ }^{228}$ FILGUEIRAS, Fernando. Corrupção, democracia e legitimidade. Belo Horizonte: UFMG, 2008, p. 181.

${ }^{229}$ RAWLS, John. Uma teoria da justiça. São Paulo: Martins Fontes, 2008, p. 66.
} 
regra é exatamente a proteção da dignidade e da honra do Parlamento, garantindo sua legitimidade institucional enquanto órgão de representação popular; assim, "tal instituto se manifesta como expressão da moralidade institucional relativa aos parlamentares, em favor da instituição Parlamento". ${ }^{230}$

Em adendo a esse raciocínio, diz Carla Costa Teixeira:

O decoro parlamentar seria, portanto, um dispositivo a ser acionado para resguardar e defender as virtudes relativas a uma instituição central nas democracias representativas, quando estas estivessem ameaçadas internamente. Ou seja, quando o comportamento impróprio dos representantes parlamentares pudesse estar colocando em risco a legitimidade do Legislativo. ${ }^{231}$

Em uma crescente onda de escândalos envolvendo o Poder Legislativo nacional, tornase cada vez mais importante a elaboração de instrumentos defensivos da moralidade institucional, pois, como nos diz Fernando Filgueiras, "caso não haja a construção de mecanismos de responsabilização política na institucionalidade democrática, o risco de crescente deslegitimação é grande". ${ }^{232}$

Todavia, tão relevante quanto introduzir novos mecanismos defensivos da integridade institucional é a efetivação dos já existentes. Essa situação parece posta no caso dos procedimentos de cassação de mandato parlamentar por quebra de decoro promovida pelo Poder Legislativo. Uma vez iniciado o procedimento, espera-se que, quando diante de atos de real violação dos ditames morais requeridos pelo Parlamento, a respectiva Casa a que pertence o agente violador tome todas as medidas para sua punição, evitando-se o espírito de corpo que porventura possa se abater sobre os pares. Ocorrendo descaso quanto à aplicação das penalidades devidas ou mesmo influindo interesses políticos que impossibilitam o andamento do procedimento, o resultado é a generalização da imagem negativa da instituição, o que, no Brasil, tem sido vulgarmente resumido pela ideia de que "tudo acaba em pizza". A imoralidade do agente parlamentar, embora não sendo uma imoralidade da Casa a que pertence, contamina todo o ambiente institucional pelo simples motivo de que seus pares não levaram a efeito os institutos de defesa da legitimidade da instituição. Em relação ao exposto,

${ }^{230}$ JÚNIOR, Hamilton Rangel. Princípio da moralidade institucional. São Paulo: J. de Oliveira, 2001, p. 115

${ }^{231}$ TEIXEIRA, Carla Costa. A honra da política. Rio de Janeiro: Relume Dumará, 1998, p. 158.

${ }^{232}$ FILGUEIRAS, Fernando. Corrupção, democracia e legitimidade, cit., p. 160. 
é pertinente o posicionamento de Sérgio Sérvulo da Cunha, ao fazer uma análise da moralidade governamental:

\footnotetext{
A imoralidade dos agentes do governo, em seu comportamento como agentes, não chega a ser imoralidade do governo, enquanto for episódica, reprimida e punida. Se ela constitui prática reiterada, que prevalece sobre a inexistência ou a ineficácia dos meios de controle, passa a ser imoralidade do governo, que corrói sua legitimidade.
}

O próprio procedimento de cassação por quebra de decoro gera expectativa na opinião pública. Em seu resultado, há sempre um clamor e uma satisfação, justa ou injusta, a ser realizada. Eis a problemática: o público acompanha pelos meios midiáticos o andamento dos processos e, de alguma forma, criam a imagem da possibilidade de uma justiça sumária a ser concluída pelo próprio Parlamento.

Deixamos assente nesse tópico de nossa exposição os elementos gerais que compõem a gênese, o sentido e a importância dos mecanismos de controle moral diante dos agentes públicos estatais, especificamente os agentes políticos eletivos, de modo que tal procedimento nos possibilitou achar o sentido político-jurídico particular do instrumento da cassação de mandato por quebra de decoro, instituto abarcado pela Constituição de 1988 em seu art. 55, II.

\subsection{Natureza jurídica}

Impõe agora, na trilha de nosso estudo, descortinar o modo como foram delineados os contornos jurídicos do instituto em nosso ordenamento. Iniciemos pela determinação de sua natureza, isto é, com a coleta de algumas de suas características específicas que permitem um enquadramento classificatório dentro da estrutura normativa, especificando em quais gêneros jurídicos se insere a espécie em estudo.

O primeiro aspecto importante sobre a natureza jurídica do procedimento de cassação de mandato por quebra de decoro é o que se relaciona ao seu lugar frente às típicas funções do Estado. Lembremos que nosso texto constitucional de 1988 consagra o princípio orgânico da 
separação de $\operatorname{poderes}^{233} \mathrm{em}$ seu art. 20, dizendo, in verbis: "são Poderes da União, independentes e harmônicos entre si, o Legislativo, o Executivo e o Judiciário". Com efeito, a tarefa que propomos realizar neste ponto de nossa empreitada será determinar se o exercício da competência para a cassação de mandato por quebra de decoro, do modo como prevista na Constituição de 1988, configura-se função tipicamente legislativa, executiva ou judiciária. Como restará evidente a seguir, esse enquadramento tem reflexos importantes, sobretudo quanto aos efeitos da decisão que decreta a perda de mandato no procedimento de cassação. Naturalmente, tal objetivo analítico demanda definirmos um critério científico jurídico que reflita da melhor forma a natureza do instituto.

Nossa Constituição Republicana de 1988 é clara, ao definir que a competência para a cassação de mandatos por quebra de decoro deve ser exercida exclusivamente pela Casa Legislativa a que pertencer o parlamentar que pratique a conduta ofensiva ao decoro. Eis a redação do art. 55, II, $\S 2^{\circ}$ :

\footnotetext{
"Nos casos dos incisos I, II e VI, a perda do mandato será decidida pela Câmara dos Deputados ou pelo Senado Federal, por voto secreto e maioria absoluta, mediante provocação da respectiva Mesa ou de partido político representado no Congresso Nacional, assegurada ampla defesa".
}

Destarte, tem-se, de início, que a competência para a cassação de mandato por quebra de decoro pertence ao órgão legislativo (Câmara dos Deputados e Senado Federal); entretanto, tal assertiva não está apta a nos revelar se estamos diante do exercício de uma função legislativa, executiva ou judiciária. Saber a quem cumpre cassar mandatos por quebra de decoro (critério subjetivo ou orgânico) não nos diz qual é a natureza do ato. Explica-se a situação pelo fato, já consolidado doutrinariamente, de que o exercício das atividades legislativa, executiva e judiciária nem sempre são de competência dos órgãos correspondentes a essas nomenclaturas, isso porque a separação de poderes não é um princípio rígido e absoluto. $^{234}$

\footnotetext{
${ }^{233}$ A doutrina tem criticado o uso do termo "separação de poderes" para Loewenstein - a forma correta de se referir ao fenômeno seria "separação de funções", pois seria tão somente o exercício das funções que estaria distribuído nas mãos de detentores do poder estatal (LOEWENSTEIN, Karl. Teoría de la constitución, cit., p. 55). Concordamos com a análise; entretanto, em nosso estudo não insistiremos nessa distinção.

${ }^{234}$ DI PIETRO, Maria Sylvia Zanella. Direito administrativo. São Paulo: Atlas, 2006, p. 71.
} 
Assim, constitucionalmente, os órgãos superiores estatais não são considerados ilhas isoladas, exercendo tão somente cada um sua respectiva atividade; aliás, se assim o fosse, "disso deveria resultar, em razão da hierarquia das funções, uma subordinação da autoridade executiva ao Poder Legislativo", 235 nulificando os ditames da Constituição de 1988, quando estabelece, em seu art. $2^{\circ}$, que são Poderes da União, independentes e harmônicos entre si, o Legislativo, o Executivo e o Judiciário. Como sublinha Paulo Brossard, os três poderes, "devendo ser harmônicos, não estão nem podem estar, como que soltos no espaço, mas interligados, conexos e interdependentes". ${ }^{236}$

Essa interpretação, que traduz a possibilidade de um órgão do poder exercer funções designadas tipicamente (constitucionalmente) para outro, visando acomodar o poder de maneira harmônica, encontra seu fundamento no mais célebre elaborador da teoria da separação dos poderes: Montesquieu. No Espírito das leis (1748), livro décimo primeiro, Capítulo VI, o barão de $L a$ Bréde, a pretexto ${ }^{237}$ de analisar a constituição inglesa, acabou por elaborar uma teoria não simplesmente de separação de poderes (trancheé), o que uma primeira leitura desavisada de seu texto poderia indicar, ${ }^{238}$, mas, antes, construiu uma teoria de

${ }^{235}$ HAMON, Francis; TROPER, Michel; BURDEAU, Georges. Direito constitucional. Barueri: Manole, $2005, \mathrm{p}$. 94.

${ }^{236}$ BROSSARD, Paulo. O impeachment. São Paulo: Saraiva, 1992, p. 131.

${ }^{237}$ Utilizamos a palavra "a pretexto", tendo em vista que existe muita discussão sobre se o texto de Montesquieu representaria uma invenção teórica calculada pelo autor ou um erro interpretativo, isso porque a teoria elaborada não refletiria com fidelidade a situação do objeto analisado, qual seja: a situação constitucional inglesa. Manoel Gonçalves Ferreira Filho, nesse sentido, pontua: "Mas $O$ espírito das leis é um livro publicado em 1748, precedido de longas pesquisas, inclusive de uma viagem de estudos de 1728 a 1731. Nesta, Montesquieu visitou a Inglaterra, onde pôde conhecer diretamente as instituições inglesas e seu funcionamento. Ora, na época de sua estadia nesse país - muito antes da publicação do livro - já estava bem definida a figura do Primeiro-Ministro, bem como a do gabinete e sua vinculação à maioria parlamentar. O Executivo não era mais, portanto, o rei. Entretanto, no texto $O$ espírito das leis não há uma palavra sobre isso, ao contrário, nele o Executivo é nitidamente o monarca" (FERREIRA FILHO, Manoel Gonçalves. Princípios fundamentais do direito constitucional. São Paulo: Saraiva, 2010, p. 255). Com abordagem similar, Di Ruffia afirma que: "inspirando-se na ordenação constitucional britânica do séc. XVIII, sem, todavia, colher as linhas mais significativas da evolução no sentido parlamentar, que começava se a manifestar no seio da mesma" (DI RUFFIA, Paolo Biscaretti. Direito constitucional: instituições de direito público. São Paulo: Revista dos Tribunais, 1984, p. 160). Vale lembrar que, pela leitura de Althusser, podemos concluir que Montesquieu teria calculado o erro de análise, pois a Constituição inglesa tinha que ser um modelo para o regime de Versalhes. Logo, não podia aparecer um primeiro-ministro e seu gabinete, era preciso estabelecer um parâmetro para a Monarquia Absolutista do tipo francesa. Por isso, nas três formas de governo definidas por Montesquieu, a primeira é a República, que morrerá com o passado; a segunda, a Monarquia, na qual se governa com leis fixas e estabelecidas; e a terceira é o Despotismo, no qual não há liberdade (ALTHUSSER, Louis. Montesquieu, la política y la historia. Madrid: Editorial Ciencia Nueva, 1968, p. 70-81).

${ }^{238}$ Alerta Hauriou quanto a este ponto: "Sans doute, au premier abord, il paraît supposer que les pouvoirs séparés ne participeront aux mêmes fonctions que pour s'empêcher et non pour collaborer; il n'a pás employé le mot 'collaboration' que nous considéron aujourd'hui comme étant le mot propre pour caractériser la séparation des pouvoirs souple” (HAURIOU, Maurice. Précis de droit constitutionnel. Paris: Recueil Sirey, 1929, p. 354). 
combinação de potências (puissance) ou, melhor ainda, uma teoria de "combinación, de fusion y de enlace de los poderes", ${ }^{239}$ que tinha um objetivo claramente negativo, o de negar a concentração das três funções num único órgão, de modo a evitar que pudesse cair nas mãos de um único indivíduo. ${ }^{240}$

Essa colaboração de poderes foi bem descrita por Duverger:

La collaboration des pouvoirs se caractérise par trois idées essentielles: $1^{\mathrm{a}}$ à la base, elle suppose une distinction des fonctions de l'État, qui sont confiées à des organes distincts; $2 \square$ mais ces organes ne sont pas rigoureusement spécialisés dans leurs fonctions; il y a des domaines d'action commune; $3^{\mathrm{a}}$ enfin, loin d'être rigouresement isolés les uns des autres, les organes de l'État disposent de moyens d'action réciproques. ${ }^{241}$

Assim, o que temos sob o ângulo da separação de poderes é o fato de que, preponderantemente, os órgãos estatais superiores do Estado tendem a exercer as funções típicas que lhe são atribuídas pela Constituição, de forma genérica: ao Legislativo, Executivo e Judiciário correspondem, respectivamente, à atividade de legislar, administrar e julgar. Todavia, de maneira atípica, esses órgãos exercem também funções que são prioritariamente atribuídas aos outros, exempli gratia, quando o Legislativo realiza licitação não está a legislar, mas, sim, a exercer atipicamente ou de forma imprópria atividade em geral administrativa; no mesmo sentido, quando o Executivo veta lei (art. 84, V, da Constituição Federal), está a exercer atipicamente uma função de típico contorno Legislativo. ${ }^{242}$

239 “combinação, de fusão e vinculação dos poderes" [tradução livre do autor] ALTHUSSER, Louis. Montesquieu, la política y la historia, cit., p. 85.

${ }^{240}$ Não devemos esquecer que a teoria exposta por Montesquieu tem um caráter claramente político, de modo que quase sempre a interpretação jurídica de sua teoria acaba por amputar parte importante de seu pensamento. Com efeito, vemos em suas análises que não basta que os poderes estejam separados em órgãos distintos com funções distintas e nas mãos de indivíduos diferentes, é necessário que aqueles que estejam no exercício das funções estatais não tenham origem num único estrato social. Montesquieu está legitimamente levando em conta as distinções de ordens existentes tanto na Inglaterra como na França.

241 "A colaboração dos poderes é caracterizada por três ideias essenciais: $1^{a}$ como fundamento, ela pressupõe uma distinção das funções do Estado, que estão confiadas a organismos distintos; $2 \square$ mas esses órgãos não são estritamente especializados em suas funções; há áreas de ação comum; $3^{\text {a }}$ finalmente, longe de ser rigorosamente isolados uns dos outros, os órgãos do Estado dispõe de meios de ação recíproca" [tradução livre do autor] DUVERGER, Maurice. Cours de droit constitutionnel. Paris: Librairie Du Recueil Sirey, 1946, p. 111. Nesse sentido, ver também HAURIOU, Maurice. Précis de droit constitutionnel, cit., p. 356; DI RUFFIA, Paolo Biscaretti. Direito constitucional: instituições de direito público, cit., p. 162; SCHMITT, Carl. Teoria de la constitución, cit., p. 189.

${ }^{242}$ Para uma visão geral do arranjo estruturado na Constituição das funções típicas e atípicas atribuídas a cada órgão superior estatal, ver: FILHO, Derly Barreto e Silva. Controle dos atos parlamentares pelo Poder 
É preciso, então, acomodar a cassação de mandato parlamentar por quebra de decoro ao esquema da separação de poderes a partir de outro princípio de distinção. É tentador, nesses termos, definirmos a função estatal pelo tipo objetivo de atividade desempenhada pelo órgão, ou seja, o critério distintivo estaria nas características imanentes à própria atividade (critério objetivo material). Cabe, então, verificar se o Poder Legislativo, quando promove a cassação de mandato por quebra de decoro, está a praticar objetivamente um ato legislativo, administrativo ou judicial. O critério objetivo exige, assim, que identifiquemos de antemão os elementos caracterizadores dessas respectivas atividades estatais, sem os quais não será possível aplicar o referido critério, diga-se, ou o ato apresenta algo passível de delimitar a função a que se refere, ou não poderemos fazer qualquer distinção pela natureza imanente do ato praticado.

De acordo com a ótica do Estado de Direito, classicamente, a atividade legislativa ligase à emissão de normas genéricas e abstratas. ${ }^{243}$ Já o ato de administrar, ao contrário, consubstanciaria levar a efeito o determinado pela lei, cumprindo seus ditames de forma concreta, e sua especificidade seria, assim, a aplicação da lei. Por fim, a função jurisdicional se vincularia também à aplicação concreta da norma, mas apenas em caso de conflitos interindividuais. Esses caracteres correspondem ao desenho teórico de um critério objetivo material; assim, ao analisarmos a cassação por quebra de decoro parlamentar, somos levados a concluir que, inexoravelmente, estamos diante de uma função jurisdicional.

Vejamos, nesse sentido, que não há que se falar, no caso de cassação de mandato por quebra de decoro, em exercício de função legislativa, pois, quando os membros da Câmara dos Deputados ou do Senado Federal decidem pela cassação do mandato parlamentar, esse ato opera efeitos concretos em sujeitos individualizados, os parlamentares violadores do decoro

Judiciário. São Paulo: Malheiros, 2003, p. 37-44. Note-se, contudo, que o referido autor, ao estabelecer quais são as funções típicas e atípicas de cada órgão, teve que adotar um critério definidor das referidas funções. Convém, então, assentar que, dependendo do critério adotado, a determinação das funções típicas e atípicas constitucionais pode levar a resultados diferentes - aqui apenas apontamos a obra para consulta, não fazemos qualquer analogia entre o critério adotado pelo autor e a perspectiva que visamos adotar no decorrer do desenvolvimento de nossa pesquisa.

${ }^{243}$ Nessa linha, afirma Zagrebelsky: "La generalidad es además la premisa para la realización del importante principio de la separación de poderes. Si las leyes pudiesen dirigirse a los sujetos considerados individualmente sustituirían a los actos de la Administración y a las sentencias de los jueces. El legislador concentraria en si todos los poderes del Estado. [...] Vinculada a la generalidad estaba la abstracción de las leyes, que puede definirse como 'generalidad en el tiempo' y que consiste en prescripciones destinadas a valer indefinidamente y, por tanto, formuladas mediante 'supuestos de hecho abstractos"' (ZAGREBELSKY, Gustavo. El derecho dúctil: ley, derechos, justicia. Madrid: Trotta, 2008, p. 29). Sobre essa questão, ver também: SCHMITT, Carl. Teoria de la constitución, cit., p. 149-152. 
institucional, não havendo qualquer grau de generalidade ou abstração. Trata-se, pois, de aplicação de norma a um caso de conflito (controvérsia). O Parlamento julga dando possibilidade de defesa ao parlamentar a quem se imputa a falta.

Embora analisando a Constituição de 1946 e não definindo a cassação de mandato por quebra de decoro como função jurisdicional, Themistocles Brandão Cavalcanti claramente visualizou a perspectiva ora aventada: "A Câmara funciona como verdadeiro Tribunal de Justiça; apreciando, objetivamente, a imputação feita e a conceituação do que se deve entender por 'decoro parlamentar' - isto é, dignidade moral, política, com a corporação representativa da própria soberania popular". 244

Apesar de termos encontrado um critério aplicável e razoável, que nos possibilitou um enquadramento da competência para a cassação de mandatos por quebra de decoro na estrutura dinâmica da separação de poderes, é preciso salientar que o critério material objetivo não é unanimidade na doutrina, merecendo críticas principalmente da doutrina normativista, na qual a determinação formal do direito tem preponderância. ${ }^{245}$ Nessa medida, parece-nos correto adotar a objeção levantada de Celso Antônio Bandeira de Mello quanto a tal critério. Para o renomado administrativista, não é adequada a opção pelo critério objetivo material pelo simples fato de que "em Direito, uma coisa é o que é por força da qualificação que o próprio Direito lhe atribuiu, ou seja, pelo regime que lhe outorga, e não por alguma causa intrínseca, substancialmente residente na essência do objeto". ${ }^{246}$ Logo, não é aceitável o resultado a que chegamos anteriormente, ao definirmos a competência para a cassação de mandato por quebra de decoro como exercício de função jurisdicional, pois o critério utilizado levou em conta tão somente características que seriam inerentes às funções estatais, não fazendo uma referência clara ao desenhado normativamente no ordenamento. Por tal razão, o critério objetivo material é, no caso, insuficiente. Antes de olhar para o que o próprio ato que decreta a perda do mandato nos diz, é preciso constatar os efeitos ditados pelas normas de direito.

Impõe-se, assim, compreender as funções estatais a partir das determinações jurídicas formalmente especificadas pela ordem normativa. Destarte, cumpre ao analista do direito encontrar os alicerces jurídicos mais seguros para a tipificação das funções estatais, tomando

${ }^{244}$ CAVAlCANTI, Themistocles Brandão. A Constituição Federal comentada. Rio de Janeiro: José Konfino, 1948. v. II, p. 59.

${ }^{245}$ GAUDEMET, Yves. Droit administratif général. Paris: LGDJ, 2001, p. 524.

${ }^{246}$ MELLO, Celso Antônio Bandeira de. Curso de direito administrativo. São Paulo: Malheiros, 2008, p. 34. 
como ponto de partida a ordem jurídica estabelecida. Sem dúvida, encontrar um critério completamente seguro e não sujeito a quaisquer críticas ou eventuais problemas é tarefa impossível, como o são todas as coisas que dizem respeito à questão relacional humana. Contudo, não podemos deduzir disso a impossibilidade da análise, muito menos adotar um ponto de vista relativista em relação às opções de posicionamento teórico, como se todos guardassem seu grau de "verdade"; nessa medida, temos que certos critérios são mais pertinentes cientificamente do que outros.

Com efeito, no presente estudo, optamos por acompanhar o posicionamento de José Eduardo Martins Cardozo e Celso Antônio Bandeira de Mello. Ambos trabalham com a perspectiva da existência de algumas qualidades ou elementos que, ao serem atribuídos pelo ordenamento jurídico como efeito do exercício das funções estatais, acabam por delinear uma característica típica: legislativa, executiva ou judiciária. Adotam, pois, uma classificação de caráter formal. Esse critério é definido por Di Ruffia da seguinte maneira:

\begin{abstract}
A classificação formal se refere às diferentes formas adotadas pelos atos realizados pelos vários Poderes, em boa parte se identifica com a orgânica, já que, normalmente, todo Poder emana os próprios atos com uma forma típica - essencialmente: a lei formal para o Legislativo (ou a lei constitucional para o constituinte), o decreto para o Executivo, e a sentença para o Judiciário [...]. Acrescente-se a isto que, em regra, todos os atos emanados por um Poder, além de assumir sua forma típica, adquirem, ao mesmo tempo, a eficácia própria dos atos formais desse Poder (a chamada eficácia formal). ${ }^{247}$
\end{abstract}

Seguindo essa linha formalista, iniciemos esse percurso analítico pela identificação da qualidade ou elemento tipificador da função jurisdicional ou judiciária. $\mathrm{O}$ elemento que tem sido identificado como caracterizador da função jurisdicional é a "impossibilidade de revisão jurídica das decisões tomadas" 248 no âmbito dessa função. $\mathrm{O}$ aspecto que marcadamente nos dá certeza de estarmos diante do exercício de função judiciária é a presença do final enforcing power da coisa julgada em suas decisões, melhor dizendo, suas decisões gozam dos efeitos de

\footnotetext{
${ }^{247}$ DI RUFFIA, Paolo Biscaretti. Direito constitucional: instituições de direito público, cit., p. 164 e 165.

${ }^{248}$ CARDOZO, José Eduardo Martins. Consulta n. 001/2007. Conselho de Ética e Decoro Parlamentar da Câmara dos Deputados. Cadernos de Pós-Graduação em Direito: estudos e documentos de trabalho, n. 4. Comissão de Pós-Graduação da Faculdade de Direito da USP. São Paulo: Manole, 2011, p. 11.
} 
imutabilidade da coisa julgada, o que nenhuma das outras funções têm por característica (normativamente).

A função jurisdicional do Estado não é aquela na qual simplesmente se julga de modo imperativo conflitos interindividuais, mas a que traz a possibilidade de uma eficácia imutável da decisão tomada. Uma vez decidida a controvérsia de forma definitiva na esfera do respectivo órgão estatal e não havendo mais a quem recorrer para a desconstrução da decisão, estamos diante de função jurisdicional. Eis uma característica que encontra respaldo na doutrina:

\begin{abstract}
Afigura-se-nos que a função jurisdicional é de índole substitutiva. [...] Todavia, para que tal substituição ocorra com eficácia imutável, como dissemos, necessário se faz que uma qualidade seja agregada a essa atividade substitutiva, ou seja, mais precisamente, que se some à autoridade da solução a qualidade de imutabilidade da própria sentença, na sua parte decisória. O que caracteriza, na quase totalidade dos casos, verdadeiramente essa função da sentença enquanto síntese da atividade jurisdicional, e, tendo em vista a parte dispositiva da sentença - é a autoridade da coisa julgada. ${ }^{249}$
\end{abstract}

Nesse particular, Candido Rangel Dinamarco aduz que, "das funções realizadas pelo Estado, é a jurisdição a única dotada do predicado de definitividade, caracterizado pela imunização dos atos realizados". ${ }^{250}$ No direito nacional está consagrada a eficácia dessas decisões proferidas pelos órgãos jurisdicionais no art. 467 do Código de Processo Civil, que estabelece: "Denomina-se coisa julgada material a eficácia, que torna imutável e indiscutível a sentença, não mais sujeita a recurso ordinário ou extraordinário".

No que atina à função legislativa, podemos determiná-la como aquela caracterizada pela emissão de normas gerais e abstratas que inovam inicialmente na ordem jurídica ${ }^{251}$ a partir, em regra, da própria Constituição. Em outras palavras, é a função que normatiza a vida social pelo exercício de uma competência que se dá no cumprimento direto e imediato de ditames constitucionais, não passando pelo sistema normativo infraconstitucional. Em suma, a

\footnotetext{
${ }^{249}$ ALVIM, Arruda. Manual de direito processual civil. São Paulo: Revista dos Tribunais, 2008, p. 182-183.

${ }^{250}$ DINAMARCO, Candido Rangel. Instituições de direito processual civil. São Paulo: Malheiros, 2004. v. I, p. 333.

${ }^{251}$ MELLO, Celso Antônio Bandeira de. Curso de direito administrativo, cit., p. 36.
} 
legislação é o cumprimento da Constituição. ${ }^{252}$ Por óbvio, o caso não se confunde com a função jurisdicional, porque não diz respeito à aplicação de norma a uma controvérsia cuja decisão definitiva tenha o efeito de coisa julgada.

Chegamos agora ao ponto no qual é preciso definir a qualidade inerente à função administrativa (executiva). Em geral, poderíamos indicar um critério residual ou negativo; assim, o que não se enquadrar nas duas funções anteriormente analisadas, pode ser designado como função administrativa. Todavia, é preciso encontrar a formalidade diferenciadora.

O que podemos constatar é o fato de que, formalmente, a função administrativa está determinada por atos controláveis em sua legalidade pelo Poder Judiciário; logo, as decisões emitidas no exercício dessa competência não são afetadas pela autoridade da coisa julgada. Em diapasão com a análise, temos as palavras da lavra de Yves Gaudemet:

\begin{abstract}
Ainsi, à la différence des actes formellement législatifs, tous les actes formellement administratifs son assujettis à un contrôle juridictionnel, et en particulier, dès lors qu'ils ont des effects de droit, ils sont susceptibles d'être attaqués en annulation par la voie Du recours pour excés de pouvoir. La notion formelle de l'acte administrative est ainsi la plus importante par les conséquences qu'elle emporte sur le regime juridique de l'acte. ${ }^{253}$
\end{abstract}

Na mesma ordem considerações, leciona Lúcia Valle Figueiredo que: “A característica essencial e fundamental do ato administrativo do Estado de Direito é sua contrastabilidade pelo Poder Judiciário". ${ }^{254}$

No mais, devemos ressaltar que a função administrativa está calcada, em regra, no cumprimento das normas infraconstitucionais, não tendo a característica de inovação inicial na ordem jurídica a partir de determinações emanadas direta e imediatamente da Constituição.

Estabelecidos esses parâmetros, podemos agora enfrentar a problemática que nos persegue no presente tópico: em qual função estatal podemos enquadrar a cassação de mandato por quebra de decoro promovido pelo Poder Legislativo?

252 Essa especificidade da legislação pode ser retirada diretamente do pensamento kelseniano: "Como a Constituição regula, no essencial, a elaboração das leis, a legislação é, com respeito a ela, aplicação do direito" (KELSEN, Hans. Jurisdição constitucional. São Paulo: Martins Fontes, 2007, p. 126).

253 “Assim, diferentemente dos atos formalmente legislativos, todos os atos formalmente administrativos estão sujeitos a um controle judicial e, em especial, quando eles têm efeitos jurídicos, são susceptíveis de serem anulados pela via de o recurso por abuso de poder. O conceito formal de ato administrativo é assim o mais importante no que diz respeito às consequiências que importa sobre o regime jurídico do ato" [tradução livre do autor] GAUDEMET, Yves. Traité de droit administratif. Paris: LGDJ, 2001, p. 514.

${ }^{254}$ FIGUEIREDO, Lúcia Valle. Curso de direito administrativo. São Paulo: Malheiros, 1998, p. 127. 
De acordo com nosso ordenamento jurídico, parece evidente que a cassação de mandato por quebra decoro exercido pelo Poder Legislativo, nos termos do art. 55 , II, $\S 2^{\circ}$, da Constituição Federal, configura exercício de função passível de ser revista pelo Poder Judiciário, pelo menos no âmbito de sua legalidade. Logo, conclui-se que o Poder Legislativo, ao determinar a perda de mandato de um de seus membros por conduta ofensiva ao decoro da respectiva Casa parlamentar, não está exercitando função judiciária em caráter atípico ou impróprio. Isso resulta do fato de que a Constituição de 1988 consolida em seu texto o princípio da inafastabilidade do controle jurisdicional; destarte, encontramos a seguinte redação no art. $5^{\circ}, \mathrm{XXXV}$, in verbis: "a lei não excluíra da apreciação do Poder Judiciário lesão ou ameaça a direito". É este, pois, um princípio basilar do Estado de Direito. ${ }^{255}$

Na esteira desse desdobramento, temos o parecer de José Eduardo Martins Cardozo:

Ora, se assim é, parece óbvio que qualquer decisão tomada pelo Poder Legislativo quanto à perda do mandato de quaisquer de seus membros, na medida em que poderá implicar lesão ou ameaça de direitos daquele que é por ela atingido, sempre poderá ser revista pelo Poder Judiciário. Logo, jamais será imutável, definitiva, impossível de ser revista. Jamais produzirá, per se, a denominada autoridade de coisa julgada. ${ }^{256}$

Afastada a primeira conclusão a que havíamos chegado quando estabelecemos que a cassação de mandato por quebra de decoro configuraria exercício de função jurisdicional atípica exercida pelo Parlamento, é pertinente agora desdobrar a questão quanto à possibilidade de se tratar de exercício função legislativa. Impende considerar que estamos diante de uma função que, ao ser efetivada, coloca-se no mundo como um ato concreto e individualizado, melhor dizendo, determinado membro do Parlamento, sempre identificável, perde o mandato como resultado do procedimento de cassação. Nessa medida, não encontramos as características de abstração e generalidade no exercício da função, qualidades

\footnotetext{
${ }^{255}$ É esse um princípio essencial para a garantia da liberdade do indivíduo contra possíveis abusos por parte dos poderes instituídos. Lembre-se de que, no regime ditatorial anterior a 1988, um dos instrumentos que garantiam o abuso do poder estatal por parte das "autoridades" foi exatamente a neutralização do princípio da inafastabilidade do controle jurisdicional pelo art. 11 do Ato Institucional n. 5, de 12 de dezembro de 1968, o qual determinava que: "Excluem-se de qualquer apreciação judicial todos os atos praticados de acordo com este Ato Institucional e seus Atos Complementares, bem como os respectivos efeitos".

${ }^{256}$ CARDOZO, José Eduardo Martins. Consulta n. 001/2007, cit., p. 14.
} 
típicas de produtos legislativos, como já deixamos assentado. Não está o Parlamento a inovar na ordem jurídica; pelo contrário, apenas cumpre a Constituição realizando um ato concreto.

Dessa análise conclui-se que a cassação de mandato por quebra de decoro promovida pelo Poder Legislativo, na forma como estabelecida pela Constituição de 1988, configura exercício atípico de função administrativa. No processo de cassação por quebra de decoro, “o Plenário da Câmara a que pertence o congressista não legisla. Administra. [...] O projeto de Resolução, submetido à votação secreta, se for aprovado por maioria absoluta, transforma-se no ato administrativo de cassação". 257

Segue-se, assim, a linha de raciocínio de Augustin Gordillo:

El régimen jurídico próprio de la función jurisdicional es que la decisión pueda ser definitiva y, fundametalmente, que sea producida por un órgano imparcial (ajeano a la contienda; un tercero desinteresado del proceso) e independiente [...] Concluimos así en que la administración no ejerce en ningún caso función jurisdicional. Si sus actos se parecen en alguna hipótesis, por su contenido, a los de aquella función, no tienen sin embargo el mismo régimen jurídico; esto es, la administración no realiza función jurisdicional. A igual conclusión cabe arribar en el caso del Congreso, aunque podría aqui haber lugar a algunas dudas. El único caso en que podría decirse que el Congreso ejerce función jurisdicional es en realidad el del juicio político. No compartimos tal critério, por considerar que se trata simplemente de la remoción de un funcionário público - acto eminentemente administrativo - sujeta a ciertas garantías que salvaguardan el derecho de defensa del interesado; pero a todo evento podría recordárselo como una hipótesis de excepción. Con tal posible reserva, pues, concluímos aquí también en que el Poder Legislativo no ejerce función jurisdiccional. ${ }^{258}$

257 CRETELLA JÚNIOR, José. Comentários à Constituição brasileira de 1988. Rio de Janeira: Forense Universitária, 1992. v. V, p. 2.671.

258 "O regime jurídico próprio da função jurisdicional é aquele em que a decisão possa ser definitiva e, fundamentalmente, que seja produzida por um órgão imparcial (alheio ao litígio; um terceiro sem interesse no processo) e independente [...] Concluímos assim que a administração não exerce em nenhum caso função jurisdicional. Se seus atos se parecem em alguma hipótese, por seu conteúdo, com os daquela função, não têm, todavia, o mesmo regime jurídico; ou seja, a administração não realiza função jurisdicional. À mesma conclusão se pode chegar no caso do Congresso, embora aqui poderiam haver algumas dúvidas. O único caso em que se poderia dizer que o Congresso exerce função jurisdicional é na realidade o do juízo político. Não compartilhamos tal critério, por considerar que se trata simplesmente da remoção de um funcionário público - ato eminentemente administrativo - sujeito à certas garantias que resguardam o direito de defesa do interessado; mas todo o evento poderia ser lembrado como uma hipótese de exceção. Com essa reserva, pois, concluímos aqui que também $o$ Poder Legislativo não exerce função jurisdicional." [tradução livre do autor] GORDILLO, Agustín. Tratado de derecho administrativo. Belo Horizonte: Del Rey, 2003. t. I, p. IX-13. 
Decerto, esse enquadramento da cassação de mandato por quebra de decoro no regime jurídico administrativo evidencia sua analogia e sua aproximação com os procedimentos disciplinares promovidos no âmbito da Administração, visando punir agentes públicos faltosos com seus deveres funcionais, notadamente os de ordem moral. Caracteriza-se, assim, a cassação de mandato por quebra de decoro como uma forma de responsabilidade disciplinar, que, no campo administrativo, diz respeito à "aplicação de medidas coercitivas, ao agente público, pela infringência das normas jurídicas ordenadoras da prestação da sua atividade como tal". 259

Devemos, todavia, tomar cuidado ao realizar essa análise, já que não se pode colocar lado a lado o agente público servidor (burocrático) e o representante político, e isso não só do ponto de vista sociológico mas também do normativo, pois os regimes jurídicos a que cada tipo de agente se submete são caracterizados com certo grau de particularidade que os distanciam. Convém, assim, levar em consideração o alerta do Ministro Carlos Brito:

\footnotetext{
... quero lembrar que todos esses temas aqui agitados - mandato parlamentar, decoro parlamentar, perda de mandato, seja por extinção, seja por cassação, licença de parlamentar, investidura - são temas que, na Constituição, têm um sentido não inteiramente coincidente com outras esferas do Direito, notadamente o Direito Administrativo. Vale dizer, a Constituição nos ministra elementos conceituais próprios para o entendimento de cada uma dessas figuras, levando-nos a uma postura de análise marcantemente heterodoxa. (Supremo Tribunal Federal, MS 25.579/DF, Rel. Min. Sepúlveda Pertence, DJU de 24.08.2007.)
}

Assentada a natureza administrativa do procedimento de cassação de mandato parlamentar por quebra de decoro previsto no art. 55, II, da Constituição, importa imediatamente caracterizarmos sua natureza jurídica diante dos tipos de responsabilidades previstas na esfera do direito. Nosso próximo passo será, precisamente, verificar em que medida a cassação de mandato por quebra de decoro consubstancia uma responsabilidade do tipo política e o que isso significa para o sistema normativo constitucional brasileiro.

Iniciemos, então, com a afirmação de que a competência para a cassação de mandato por quebra de decoro, consoante teor do art. 55, II, da Constituição de 1988, configura

${ }^{259}$ MELLO, Oswaldo Aranha Bandeira de. Princípios gerais de direito administrativo. Rio de Janeiro: Forense, 1969. v. II, p. 490. 
exercício de função política. Mais especificamente, pode-se dizer que estamos diante de uma competência para impor responsabilidade política. ${ }^{260} \mathrm{O}$ membro da Câmara ou do Senado faltoso com seus deveres morais responderia de forma política perante seus pares. Assim é comum separar esse tipo de responsabilidade da responsabilidade penal, civil e administrativa, ${ }^{261}$ com as quais não se confundiria.

Nesse particular, sem adentrar na análise propriamente da responsabilidade política, poderíamos nos perguntar se essa competência que se dá no exercício de uma função política não corresponderia a uma quarta função a que se somaria à tripartite: legislativa, executiva e judiciária, ou melhor, conforme nos diz Afonso Rodrigues Queiró “... como quer que deva definir-se e qualificar-se em dado momento cada uma destas três clássicas funções estaduais, haverá lugar para uma quarta função, para uma quarta espécie de actividade do Estado?”262

Tendemos a responder a essa indagação de modo negativo, pelo fato de que a nossa análise se dá à luz da arquitetura constitucional concretamente adotada pela Carta Republicana de 1988, na qual o arranjo dos órgãos superiores do Estado consagra a separação tripartite das funções estatais $\left(\operatorname{art} .2^{\circ}\right.$ ). Desse modo, se por um lado podemos identificar de alguma forma funções que parecem ser distintas das três constitucionalmente reconhecidas, por outro somos obrigados a lançar essas funções como uma característica qualificadora das funções existentes, e não como uma quarta função. Assim, politicamente, podem atuar tanto o Poder Legislativo como o Executivo. ${ }^{263}$ Destarte, há de fato atividades que podem ser classificadas de políticas e que, na dinâmica estatal, acabam por ter efeitos jurídicos importantes, como teremos

\footnotetext{
${ }^{260}$ Convém lembrar que a responsabilidade política encontra sua origem na inversão da forma de legitimação do poder ocorrida sob o influxo do pensamento constitucional democrático. Antes do advento do Estado de Direito, o poder estatal sob a tutela do príncipe era um poder encarnado em sua própria pessoa ("L'État c'est moi"), e o exercício do poder estava submetido a fórmulas do tipo the king can do no wrong, um poder que só se responsabilizava perante esferas místicas para além das relações humanas. Nesse sentido, dizia nossa Carta monárquica de $1824 \mathrm{em}$ seu art. 99 que "a pessoa do imperador é inviolável, e sagrada. Elle não está sujeito à responsabilidade alguma". Consoante Pedro Lomba: "O princípio da responsabilidade política, adoptado pelos regimes liberais e pelo constitucionalismo, remonta à preocupação da filosofia medieval com a moderação e legitimação do poder político. A sua implantação só se tornou possível com a revisão das concepções religiosas e teocráticas sobre a origem do poder político. Enquanto as comunidades políticas estiveram sob a autoridade e um Rex Dei Gratia, representante da vontade divina, a ideia de responsabilidade política não se pôde manifestar" (LOMBA, Pedro. Teoria da responsabilidade política. Coimbra: Coimbra Editora, 2008, p. 26).

${ }^{261}$ CUNHA, Sérgio Sérvulo da. Fundamentos de direito constitucional. São Paulo: Saraiva, 2004, p. 394.

${ }^{262}$ QUEIRÓ, Afonso Rodrigues. Teoria dos actos de governo. Coimbra: Coimbra Editora, 1989. v. I: Estudos de Direito Público, p. 506.

${ }^{263}$ Nesse sentido, aduz Queiró: “A actividade do Parlamento é bem, por conseguinte, actividade política, no mesmo sentido em que o é a actividade governamental da Administração" (QUEIRÓ, Afonso Rodrigues. Teoria dos actos de governo, cit., p. 525).
} 
oportunidade de ver, mas não perfazem uma "nova categoria de atos que possam ser postos ao lado dos atos legislativos, administrativos e jurisdicionais" ${ }^{\text {264 }}$ - eles apenas não se alocam satisfatoriamente na moldura da tripartição de poderes. ${ }^{265}$

O importante, então, é compreendermos como a cassação de mandato por quebra de decoro consubstancia uma espécie de responsabilização política distinta das realizadas pela esfera penal, civil e administrativa.

O primeiro aspecto que devemos observar é o de que a ideia de uma responsabilidade política só pode ocorrer na esfera de uma relação política. As relações que envolvem agente público administrativo (servidor público em geral) e Administração destoam em larga medida daquelas que dizem respeito ao agente político parlamentar e à instituição legislativa. Neste último caso, põe-se em evidência uma relação de caráter democrático representativo, que envolve confiança popular, sufrágio e competição eleitoral, no qual impera a necessidade de satisfação de uma opinião pública para a manutenção do consenso democrático. A clássica distinção entre o burocrata e o político ${ }^{266}$ se coloca, com efeito, no centro da discussão. As características dos tipos de responsabilidades assumidas pelos servidores públicos administrativos em geral e pelos agentes políticos parlamentares em sua particularidade política são distintas, dada a natureza das funções reservadas a cada um na estrutura do Estado.

Agentes políticos assumem responsabilidades políticas, cujo momento ápice é o confronto eleitoral: “... no regime democrático, determinados círculos mais amplos ou mais

${ }^{264}$ ELAERES, José Marques Teixeira. A doutrina das questões políticas no Supremo Tribunal Federal. Porto Alegre: Fabris Editor, 2005, p. 58. Interessante notar a forma como Jorge Miranda propõe sua classificação das funções estatais: “... propomos uma distinção (sem pretensões de originalidade) entre função política, função administrativa e função jurisdicional; e na função política uma subdistinção entre função legislativa e função governativa (ou política stricto sensu)" (MIRANDA, Jorge. Funções do Estado. Rio de Janeiro: Revista de Direito Administrativo, 1991, p. 92).

${ }^{265}$ MELLO, Celso Antonio Bandeira de. Curso de direito administrativo. São Paulo: Malheiros, 2008, p. 36.

${ }^{266} \mathrm{Um}$ dos autores que de forma mais interessante trabalhou essa questão foi Max Weber, embora tenha tomado a questão de um ponto de vista sociológico, e não jurídico. Em obra clássica, aborda a distinção entre político e burocrata, distinguido-os pelo tipo de responsabilidade que cada uma assume: "A diferença acha-se, antes, no tipo de responsabilidade, e é isto que realmente determina as diferentes exigências dirigidas a ambas as espécies de cargos. Um funcionário que recebe uma diretriz a qual ele considera errônea pode e deve objetar a ela. Se seu superior insistir na execução de tal diretriz, é dever do funcionário e até seu motivo de orgulho executá-la como se isso correspondesse à sua convicção mais íntima, demonstrando assim que sua consciência do dever coloca-se acima de suas preferências pessoais. Não importa se a ordem emana de um 'órgão', de uma 'companhia' ou de uma assembleia. É o ethos (uso, costume) das funções (office). Um líder político que agisse desta maneira mereceria desprezo. Ele frequentemente será forçado a fazer concessões, isto é, sacrificar o menos importante ao mais importante" [WEBER, Max. Parlamentarismo e governo numa Alemanha reconstruída. São Paulo: Abril Cultural, 1974. v. XXXVII, p. 33. (Coleção Os Pensadores).]. 
reduzidos do povo do Estado dispõem de um poder político eficaz que se revela praticamente, sobretudo, na nomeação, demissão e controle dos dirigentes políticos". ${ }^{267}$

Nesse sentido, a seguinte passagem de Madson é salutar:

O objetivo de qualquer constituição política é - ou deve ser - antes de tudo escolher como dirigentes as pessoas mais capacitadas para discernir e mais eficientes para assegurar o bemestar da sociedade; depois, tomar as mais seguras precauções no sentido de conservá-las eficientes enquanto desfrutarem da confiança pública. O processo eletivo de escolher dirigentes é a norma característica do governo republicano. Os meios com que conta esta forma de governo para evitar sua degeneração são numerosos e variados. $\mathrm{O}$ mais eficaz consiste na limitação do período dos mandatos, visando manter uma adequada responsabilidade perante o povo. $^{268}$

Com efeito, temos que responsabilidade política e representação política estão intrinsecamente ligadas. É o representante político, como agente mandatário do povo que responde politicamente por suas condutas. Em termos históricos, a imagem categórica desse status de responsabilidade está no art. 15 da Declaração dos Direitos do Homem e do Cidadão, de 1789, ao ditar que: "La société a le droit de demander compte à tout agent public de son administratio" ${ }^{269}$. Isso significa que não só o representante político deve atuar de maneira representativa mas também que essa representação tem um caráter democrático, digase: é uma representação responsável frente ao eleitorado. ${ }^{270}$ Fala-se, dessa forma, que o governo responsável é aquele que tem o dever de prestar contas (accountability).

${ }^{267}$ HELLER, Herman. Teoria do Estado, cit., p. 294.

${ }^{268}$ HAMILTON, Alexander; MADSON, James; JAY, John Jay. O federalista, n. 57. Brasília: Universidade de Brasília,1984, p. 451.

269 "A Sociedade tem o direito de demandar contas a qualquer agente público de sua administração" [tradução livre do autor].

${ }^{270}$ Sartori capta essa questão de maneira peculiar e inteligente: "Etimologicamente falando, representar quer dizer: apresentar de novo, e por extensão, tornar presente alguma coisa ou alguém que não está presente. Pois bem, esta noção pode ser desenvolvida, em matéria política, em dois modos diferentes: no sentido de um corpo restrito que está para a coletividade inteira assim como (segundo a imagem de Mirabeau) uma carta geográfica está para o território que representa; ou então no sentido de que entre os ausentes e aqueles que estão presentes por eles se verifique uma obrigação de responder, algum liame e vínculo que exija deles prestação de contas. Na primeira hipótese representação é 'representatividade'; na segunda é 'responsabilidade'. O fato destas duas acepções poderem se acumular e apresentarem-se na realidade juntas, não impede que não devam ser confundidas, e que cumpre distinguir cuidadosamente uma 'correspondência' que é semelhança, da outra 'respondência' que é responsabilidade" (SARTORI, Giovanni. A teoria da representação no Estado representativo moderno. Minas Gerais: Revista Brasileira de Estudos Políticos, 1962, p. 51). 
Nesse sentido, afirmam Manin, Przeworski e Stokes que: "Governments are 'accountable' if citizens can discern representative from unrepresentative governments and can sanction them appropriately, retaining in office those incumbents who perform well and ousting from office those who do not". ${ }^{271} \mathrm{Na}$ esteira desse raciocínio, Garcia de Enterria também é categórico ao aduzir que "Esta obligación de 'dar cuenta' es universal y debe ser efectiva, porque está en la raiz misma del princípio democrático". ${ }^{272}$

Assim, podemos considerar que, "como a representação procede das eleições, a responsabilidade política é também realizada pela via eleitoral". ${ }^{273}$ A eleição é o ponto-chave, pois, da responsabilidade política, é a forma usual da ocorrência desse tipo de responsabilização:

\begin{abstract}
A infidelidade aos compromissos assumidos ou excessos, desmandos, abusos ou desvios que se cometam no exercício do mandato, com a violação das prescrições éticas cabíveis - mesmo sem chegar aos extremos da inconstitucionalidade ou da violação de deveres legais -, resolvem-se pelos processos políticos normais, e o sistema eleitoral aponta o caminho normal para a solução desse tipo de problema. ${ }^{274}$
\end{abstract}

Não significa, diga-se de passagem, que a responsabilidade política é um fenômeno somente de via eleitoral; se isso fosse verdade, a cassação de mandato por quebra de decoro, conforme especificado no texto constitucional de 1988, não caracterizaria uma espécie de responsabilização política, de modo que nossa análise neste tópico seria inútil.

Desde já, cumpre reafirmar que a cassação de mandato por quebra de decoro constitui uma forma de responsabilidade política, tendo a mesma natureza que aquela advinda do processo eleitoral; ${ }^{275}$ todavia, não é idêntica, pois que a responsabilização do representante

271 “Os governos são "responsáveis” se os cidadãos são capazes de diferenciar os governos representativos dos não representativos e podem punir esses de forma adequada, mantendo no cargo os agentes que desempenharem bem o seu papel e destituindo do cargo aqueles que não o fizerem." [tradução livre do autor] MANIN, Bernard; PRZEWORSKI, Adam; STOKES, Susan. Democracy, accountability and representation, cit., p. 10.

272 "Esta obrigação de 'prestar conta' é universal e deve ser efetiva, porque está na própria raiz do princípio democrático." [tradução livre do autor] ENTERRÍA, Eduardo Garcia. El principio de "la responsabilidad de los poderes públicos" según el art. 9.3 de la Constittución y la responsabilidad patrimonial del estado legislador, cit., p. 41.

${ }_{273}^{27}$ LOMBA, Pedro. Teoria da responsabilidade política, cit., p. 79.

${ }^{274}$ ATALIBA, Geraldo. República e constituição. São Paulo: Malheiros, 2007. p. 68.

${ }^{275}$ De fato, a ideia da responsabilidade política é muito mais ampla do que o demonstrado pela responsabilização no sistema eleitoral, pois que o cerne da responsabilidade política está nos controles que a própria constituição estabelece, ou seja, o ordenamento constitucional não só determina a responsabilidade política entre representantes e representados mas coloca esse mesmo mecanismo nas mãos dos detentores do poder político, que pode ser posto como controle entre órgãos ou internamente aos órgãos, encaixando-se nesse último caso a 
político no caso se dá frente aos seus pares (art. 55, § $2^{\circ}$, da Constituição Federal), o agente responsabilizador não é o eleitorado diretamente. A princípio, o que há em comum entre esses dois tipos de responsabilidade política é que ambas se aplicam aos representantes políticos, ou seja, é uma responsabilidade afixada ratione personae conforme o status do agente, ${ }^{276}$ mas tal fato, como bem salienta Pedro Lomba, configura apenas um pressuposto da responsabilidade política, sendo insuficiente para caracterizar e impregnar no instituto sua marca distintiva. ${ }^{277}$

Passemos, então, a abordar a questão por outro aspecto, o formal. Há concordância na doutrina ao estabelecer que o exercício de função política na esfera do Estado é caracterizado por um alto grau de discricionariedade. ${ }^{278}$ Nesse particular, aduz Manoel Gonçalves Ferreira Filho que: "chamam-se questões políticas aquelas que a Constituição confere à apreciação discricionária do Executivo ou do Legislativo. São questões de apreciação de conveniência, das quais a lei só marca o contorno, deixando em sua substância a decisão ao órgão político". 279

Paulo Brossard delineou essa característica típica da função política afirmando que: “dizem respeito a questões indefinidas e indefiníveis, novas, variadas, movediças, cambiantes. Não se enquadram em esquemas apriorísticos, não se deixam capturar em classificações legais, não se distribuem em tipos que possam ser descritos e catalogados". 280

Não menos elucidativas são as palavras de Carl Schmitt:

No hay ninguna regulación constitucional en ninguna Constitución de la tierra que pueda regular normativamente con los caracteres de una ordenación cerrada de procedimento, la cuestión de la dirección política. La ojeada que hemos realizado muestra cuán diversas posibilidades caben en las mismas palabras, como "responsabilidad" o "confianza". Tales cuestiones no pueden resolverse ni a modo de mandato ni de procedimiento. Por eso, sería

competência para a cassação de mandato por quebra de decoro que é atribuída ao próprio órgão a que pertence o agente a ser responsabilizado. Nesse contexto, são importantes as palavras de Loewenstein "... el constitucionalismo no es solamente un gobierno con uma base de Estado de derecho, sino que significa un gobierno responsable. Un gobierno se puede considerar como responsable cuando el ejercicio del poder político está distribuído y controlado entre diversos detentadores del poder (LOEWENSTEIN, Karl. Teoría de la constitución, cit., p. 71).

${ }^{276}$ CUNHA, Sérgio Sérvulo da. Fundamentos de direito constitucional, cit., p. 394.

${ }^{277}$ LOMBA, Pedro. Teoria da responsabilidade política, cit., p. 70.

${ }^{278}$ MIRANDA, Jorge. Funções do Estado, cit., p. 94.

${ }^{279}$ FILHO, Manoel Gonçalves Ferreira. Curso de direito constitucional. São Paulo: Saraiva, 1999, p. 244.

${ }^{280}$ BROSSARD, Paulo. O impeachment, cit., p. 141. 
también locura apelar aqui a un Tribunal para tratar en forma judicial la cuestión de la dirección política, y determinar en forma judicial las directrices de la política. ${ }^{281}$

Destarte, temos que a responsabilidade política (competência particularizada na esfera do exercício da função política) está imbuída precisamente dessas mesmas características ora aludidas, isto é, seu aspecto político diz respeito à dificuldade de apreensão fechada e absoluta pelo direito positivado. Pense-se, a título exemplificativo, que, no momento eleitoral no qual a apreciação realizada pelo cidadão sobre se um governo satisfez ou não suas expectativas esta permeada por um alto grau de liberdade, não existindo uma determinação do ordenamento jurídico que possa apreender os pressupostos de como o julgamento deve ser feito pelo povo. Não é algo que possa ser mensurável ou calculável pelo ordenamento, diz respeito à conveniência e à oportunidade política do cidadão. "A acção política caracteriza-se por uma grande liberdade de meios e de fins, aparentemente incompatíveis com os pressupostos tradicionais da responsabilidade jurídica." 282

Inevitável, então, nos perguntarmos se a cassação de mandato por quebra de decoro tem essa característica do alto grau de discricionariedade. A resposta é positiva: o art. 55, II, da Constituição Federal, ao prever o instituto da cassação de mandato para quebra de decoro, em seu $\S 2^{\circ}$, determinou que o juízo decisório é de competência da respectiva Casa legislativa a que pertence o parlamentar faltoso, ou seja, os membros de cada uma delas decidem de forma "livre" se houve ou não ofensa à dignidade institucional e se é conveniente e oportuno decretar a perda do mandato. Nesses termos salutares, as palavras de José Eduardo Martins Cardozo:

Na medida em que envolvem um âmbito de apreciação discricionária do Parlamento, inegavelmente, implicam um juízo de conveniência e oportunidade política sobre a perda do

\footnotetext{
281 "Não existe nenhuma regulação constitucional em nenhuma Constituição da Terra que possa regular normativamente com o caráter de ordenação fechada de procedimento a questão da direção política. A avaliação que temos realizado mostra quão diversas possibilidades cabem nas mesmas palavras, como "responsabilidade" ou "confiança". Tais problemas não podem ser resolvidas como questões de mandato ou de procedimento. Por isso, seria também loucura apelar aqui a um Tribunal para tratar de forma jurídica o problema da direção política e determinar de forma judicial as diretrizes da política." [tradução livre do autor] SCHMITT, Carl. Teoria de la constitución, cit., p. 331-332.

${ }^{282}$ LOMBA, Pedro. Teoria da responsabilidade política, cit., p. 20.
} 
mandato. Deve-se avaliar, a partir da realidade política, se é conveniente ou não a sua desconstituição. ${ }^{283}$

No mesmo sentido, temos a lição de Pinto Ferreira: “É, então, um poder discricionário que tem a Câmara de expulsar os seus membros, quando sua conduta venha a ferir a própria honorabilidade da Assembleia". ${ }^{284}$

Ora, se no julgamento político realizado pelo Senado ou pela Câmara há um juízo subjetivo que pode considerar situações políticas das mais variadas, temos aqui o completo distanciamento desse tipo de processo daqueles de cunho penal, no qual vigem regras rígidas tanto em relação ao caminhar do processo quanto aos tipos penais que podem ser imputados ao infrator. O processo político de cassação de mandato por quebra de decoro não só desconhece tal rigidez como essa lhe é completamente estranha.

Os fatores políticos não são apanhados pelas contenções legais rígidas do mundo jurídico, o julgamento na esfera da responsabilidade política pode levar em conta situações que, por exemplo, a um membro do Poder Judiciário em processo criminal ou civil é vedado conhecer ou considerar em sua decisão. Um juiz não pode levar em conta em sua decisão questões como o temor da opinião pública ou da imprensa, ${ }^{285}$ ou o impacto que seu julgamento pode ter para a imagem da instituição judiciária; antes, deve atentar-se apenas à perspectiva normativa jurídica. Já para a decisão no âmbito da cassação de mandato por quebra de decoro, tais questões são de suma importância e devem ser tomadas em consideração.

Assim, em processos de responsabilização política, como o da cassação de mandato por quebra de decoro, pouco importa se há culpa ou dolo na ação do agente político a quem é imputada a conduta ofensiva ao decoro institucional, ${ }^{286}$ se sua ação configura ou não ilícito penal ou civil, se causou ou não dano material, mas, sim, o desvalor político que ela provoca. Nesse particular, indica Canotilho que "a responsabilidade política é um mecanismo jurídicoconstitucional que incide sobre o desvalor jurídico e político-constitucional dos actos dos titulares do poder político". ${ }^{287}$

\footnotetext{
${ }^{283}$ CARDOZO, José Eduardo Martins. Consulta n. 001/2007, cit., p. 19.

${ }^{284}$ FERREIRA, Pinto. Comentários à Constituição brasileira. São Paulo: Saraiva, 1992. v. 3, p. 28.

${ }^{285}$ MIRANDA, Pontes. Comentários à Constituição de 1967 com a Emenda n. 1, de 1969. São Paulo: Revista dos Tribunais, 1970. t. III, p. 628.

${ }^{286}$ CANOTILHO, J. J. Gomes. Direito constitucional e teoria da Constituição. Coimbra: Almedina, 2002, p. 551.

${ }^{287}$ CANOTILHO, J. J. Gomes. Direito constitucional e teoria da Constituição, cit., p. 540.
} 
Com efeito, no campo decisional da cassação de mandato por quebra de decoro promovida pelo Parlamento não está em jogo simplesmente uma questão jurídica, mas um aspecto político inapreensível de forma completa pelo ordenamento jurídico, isso porque o objetivo do instituto é a defesa da legitimidade institucional democrática. Com respeito a esse aspecto, Dennis F. Thompson pontua que:

In simplest terms, the ethics process seeks to determine whether a member's conduct has harmed the institution; the criminal process judges whether a member's conduct has harmed society. [...] The punishment imposed by the ethics process are also more limited in scope than those imposed by criminal law. ${ }^{288}$

Não bastando, pois, que na esfera da responsabilidade política não ocorra os mesmos pressupostos para aplicação da sanção que encontramos no campo jurídico, especificamente na esfera penal e civil, devemos notar que a própria sanção a ser aplicada é distinta - é esse, aliás, um dos pontos que a doutrina indica como o central da diferenciação das esferas de responsabilidade. ${ }^{289}$ Ora, a responsabilidade penal tem o intuito de proteção dos bens mais elevados da sociedade, induzindo punições mais severas, traduzidas na possibilidade de perda da liberdade individual, funcionando, por isso, como última ratio do ordenamento jurídico. Dessa perspectiva se distancia da sanção a ser imposta nos termos de uma responsabilidade política, ${ }^{290}$ basta verificar que na cassação de mandato por quebra de decoro busca-se, em regra, afastar de forma definitiva o representante político da função parlamentar, decretando a perda de seu status político - eis uma finalidade inerente à responsabilização política, como fim maior. Eis que também podemos observar que a responsabilidade política tem finalidades

\footnotetext{
288 "Em termos simples, o processo de ético procura determinar se a conduta de um membro prejudicou a instituição; os juízes criminais procuram determinar se a conduta de um membro prejudicou a sociedade. [...] As punições impostas pelos processos éticos são também de âmbito mais limitado do que aquelas impostas pelo direito penal." [tradução livre do autor] THOMPSON, Dennis F. Ethics in congress: from individual to institutional corruption, cit., p. 28.

${ }^{289}$ Nessa perspectiva, temos Hamon, Troper e Burdeau: "Essa distinção se aplica apenas ao processo empregado e ao tipo de sanção que pode ser imposta. [...] A responsabilidade política é aquela que é praticada de acordo com um processo puramente político, ou seja, ela dá lugar a um simples voto por uma assembleia. A sanção é, nesse caso, política em si mesma, é a obrigação de pedir demissão" (HAMON, Francis; TROPER, Michel; BURDEAU, Georges. Direito constitucional, cit., 2005, p. 100-101).

${ }^{290}$ LOMBA, Pedro. Teoria da responsabilidade política, cit., p. 56.
} 
distintas da que se impõe na esfera civil, pois nesta, em geral, busca-se o reparo de um dano com a respectiva indenização. ${ }^{291}$

Esses elementos distintivos das esferas de responsabilização têm um efeito prático jurídico importante: a possibilidade de o agente político parlamentar assumir a responsabilidade em todas as esferas de forma autônoma, sem que ocorra, por isso, o fenômeno do bis in idem. Por tal razão, Uadi Lammêgo Bulos salienta que "o fato de a imputação constituir crime, sujeita o parlamentar à incidência do inciso VI, do art. 55, mas não impede a aplicação da sanção disciplinar antes da condenação criminal", ${ }^{292}$ ou seja, não há, no caso, ofensa ao princípio da presunção de inocência.

Paulo Brossard, em julgado do Supremo Tribunal Federal, desdobra precisamente essa questão:

\begin{abstract}
Sem contradição, o parlamentar poderá ser absolvido no juízo criminal e ter seu mandato extinto por falta de decoro, decretada pela Câmara. Os pressupostos de uma e outra decisão são diferentes. [...] Desse modo, o parlamentar pode ser condenado sob o ponto de vista disciplinar e absolvido no juízo criminal, e a recíproca é verdadeira, tanto assim que, por não ter relação com o exercício do mandato, pode não sofrer a perda do mandato. Em outras palavras, se o parlamentar cometer um crime a Câmara não o processará nem o condenará por isso; é atribuição do Poder Judiciário fazê-lo; mas se o fato implicar em descompostura parlamentar, falta de decoro, a Câmara poderá aplicar-lhe a sanção disciplinar da perda do mandato, seguindo-se o processo criminal na esfera própria, que poderá estar instaurado ou vier a instalar-se. (Supremo Tribunal Federal, MS n. 21.443 Rel. Min. Octávio Gallotti. RDA v. 189, p. 272, 1991.)
\end{abstract}

Não menos preciso é o parecer de Nelson Hungria:

A circunstância de que se trate de procedimento constitutivo de crime, a provocar a interferência da Justiça Penal, não apaga, como é óbvio, a sua qualidade de reflexivamente ofensiva do decôro da corporação legislativa, que, assim, não decai do soberano direito à sanção direta e específica que a lei lhe assegura privativamente. (RT, v. 285, 1959, São Paulo, MS 2.319. STF, Rel. Min. Nelson Hungria, p. 111-112.)

\footnotetext{
${ }^{291}$ MEIRELLES, Hely Lopes. Direito administrativo brasileiro. São Paulo: Malheiros, 2005, p. 496.

${ }^{292}$ BULOS, Uadi Lammêgo. Curso de direito constitucional. São Paulo: Saraiva, 2011, p. 1.099.
} 
Com efeito, temos que a responsabilização política de parlamentar em processo de cassação por quebra de decoro não impede a apuração e a sanção da mesma conduta em outras esferas de responsabilidade, notadamente as de caráter jurídico penal, civil e, conforme o caso, até administrativo. Imaginemos a hipótese de um deputado ou senador ser servidor público do quadro efetivo, mas licenciado para o exercício de sua função parlamentar. Dependendo da situação que leve à perda de seu mandato por quebra de decoro, pode-se aventar a sua responsabilização pelo mesmo fato diante do órgão estatal a que estiver ligado como servidor, diga-se: pode ser demitido em processo disciplinar administrativo. 


\section{CAPÍTULO 5 - DO PROCESSO DE CASSAÇÃO}

\subsection{Das condições para a abertura do processo ético-disciplinar}

A quebra do decoro parlamentar gera como regra a possibilidade de instauração do processo de cassação de mandato, instrumento hábil a punir o deputado ou senador faltoso com seus deveres éticos institucionais. Entretanto, impõe ressaltarmos que existem certos requisitos jurídicos necessários para que o processo seja legitimamente instaurado. De certa forma, esses requisitos ou condições têm um caráter lógico em face da natureza e dos fins do próprio processo; assim, uma vez ausentes, acabam por desautorizar a Casa parlamentar a dálo início. Na hipótese da abertura de um processo de cassação sem o preenchimento de certas condições jurídicas mínimas para sua deflagração, havendo lesão ou ameaça de lesão a direito, aquele que se sentir prejudicado poderá buscar os meios legais disponíveis para fulminar o ato ilegítimo. Feitas essas considerações, importa identificar e explorar alguns desses requisitos, que devem estar presentes no momento da abertura do processo.

\subsubsection{Competência para provocar o processo}

Nos termos do art. 55, $\S 2^{\circ}$, da Constituição Federal 1988, somente estão habilitados a provocar a instauração do processo de cassação de mandato por quebra de decoro parlamentar a Mesa da Casa legislativa a que pertencer o acusado ou partido político com representação no Congresso Nacional. São essas duas instâncias políticas que têm a competência Constitucional de requerer a abertura do processo que possa levar à cassação do mandato por quebra de decoro. Isso significa que todos os casos nos quais haja suspeita ou indícios da ocorrência de condutas violadoras do decoro parlamentar devem passar por uma dessas instâncias para averiguação quanto à pertinência da abertura do processo de cassação de mandato. São elas, pois, que indicam de início se uma dada situação será apreciada pelos órgãos internos com o intuito de ser levada à votação em plenário, para que este decida sobre a perda do mandato por quebra de decoro.

Com efeito, não haverá decretação de perda de mandato com fundamento no art. 55, II, da Constituição se nenhuma dessas esferas se manifestarem nesse sentido. Isso não quer dizer 
que qualquer cidadão não possa levar a conhecimento das respectivas Mesas legislativas ou a partido político com representação no Congresso fato que possa ser configurado como ofensivo ao decoro, mas, simplesmente, que a competência para provocar um processo com vistas a apurar a falta ética grave está nas mãos dessas instâncias, e esta é a primeira condição para que se tenha como legítima a abertura de um processo de cassação de mandato parlamentar por quebra de decoro.

\subsubsection{Sujeito passivo}

Somente aquele que ostenta o status jurídico-político de agente parlamentar está posto como alguém passível de sofrer a sanção prevista no art. 55, II, da Constituição, já que essa forma punitiva de natureza política faz parte do plexo de sujeições e prerrogativas constitucionais que perfazem o Estatuto do Congressista, regime jurídico só aplicável ao membro da Câmara dos Deputados ou do Senado Federal. É esse o sujeito passivo do processo. Destarte, nenhum membro do Congresso Nacional poderá responder por procedimento ofensivo à dignidade institucional quando já houver ocorrido a extinção ordinária ou extraordinária de seu mandato. Veja-se que, nesses casos, há a perda do próprio objeto perseguido pelo processo de cassação por quebra de decoro, que é o mandato parlamentar, não importando, a nosso ver, os eventuais efeitos secundários gerados pela aplicação da penalidade.

\subsubsection{Direito de renúncia ao mandato parlamentar e processo de cassação}

Embora não faça parte do rol estabelecido pelo art. 55 da Constituição, a renúncia configura uma hipótese de perda de mandato. Na renúncia, o parlamentar, de forma unilateral e voluntária, abre mão do mandato representativo adquirido nas urnas, ocasionando a extinção antecipada do mandato.

O Regimento Interno da Câmara dos Deputados obriga que o pedido de renúncia seja feito sempre por escrito à Mesa da Casa, não dependendo de aprovação de seus membros, mas somente se torna efetivo e irretratável depois de lido no expediente e publicado no Diário da Câmara dos Deputados (art. 239, caput, do RICD). 
No caso do Senado Federal, o seu Regimento Interno prevê que o pedido de renúncia deve ser dirigido à Mesa, com firma reconhecida, o qual independe de aprovação da Casa, tornando-se efetivo e irretratável depois de lido no período do expediente e publicado no Diário do Senado Federal (art. 29 do RISF). Há possibilidade, contudo, de o Senador ou o Suplente realizar o pedido de renúncia oralmente em plenário (art. 29, parágrafo único, do RISF).

Importa para nós observar que a renúncia constitui um direito do membro da Câmara e do Senado que resulta, quando de sua ocorrência, na perda antecipada do status jurídico político de parlamentar; logo, é de se imaginar o seu uso como um meio de fugir à eventual responsabilização em processo de cassação de mandato por quebra de decoro. A lógica de se abrir mão antecipadamente daquilo que se pode perder em processo ético-disciplinar está em não ser atingido pelos efeitos secundários típicos de eventual cassação. Como veremos em local apropriado, a decretação de perda de mandato (art. 55, II, da Constituição Federal) gera para o parlamentar punido a incapacidade para concorrer a cargos políticos eletivos (inelegibilidade). É por essa razão que a Constituição impõe alguns limites ao exercício desse direito de demissão. Nesses termos, encontramos no art. 55, $\S 4^{\circ}$, da Constituição a regra de que "a renúncia de parlamentar submetido a processo que vise ou possa levar à perda do mandato, nos termos deste artigo, terá seus efeitos suspensos até as deliberações finais", 293 ou seja, até que o processo acabe.

${ }^{293}$ Sobre o contexto que deu ensejo à redação do art. $55, \S 4^{\circ}$, da Constituição, são interessantes as palavras de José Afonso da Silva: "Quando da chamada CPI do Orçamento que levou à renúncia e à cassação de diversos parlamentares envolvidos em atos de corrupção na elaboração e execução orçamentária, relevante questão foi suscitada a respeito da posição jurídica de parlamentar submetido a processo que pudesse levá-lo à perda do mandato, no caso de que viesse, antes disso, renunciar ao seu mandato, visando a evitar as consequências da pena. Uns achavam (nós, inclusive) que, nada tendo disposto a Constituição a respeito, a renúncia implicava simplesmente a perda do mandato por via dela, mas não a suspensão da elegibilidade (inelegibilidade) por oito anos, quando se trata-se de infrigência do disposto no art. 55, I e II, da Constituição, consoante prevê o art. $1^{\circ}$, I, $b$, da lei das inelegibilidades (Lei Complementar n. 64/90, com redação da Lei Complementar n. 81/94). Outros entendiam que a renúncia não poderia evitar essa consequência. Diante dessas dúvidas, preparamos uma proposta de emenda de revisão, apresentada pelo Senador Mário Covas durante o processo revisional (PRE 016658-1), acrescentando o $\S 4^{\circ}$ ao art. 55, com teor seguinte: Será inelegível pelo prazo de oito anos o congressista submetido à investigação parlamentar ou a processo de cassação de mandato que vier a renunciar ao mandato. Não foi bem assim que o Congresso Revisional solucionou a pendência. Preferiu determinar a suspensão dos efeitos do ato de renúncia, nos termos seguintes: ' $\$ 4^{\circ}$ A renúncia de parlamentar submetido a processo que vise ou possa levar à perda do mandato, nos termos deste artigo, terá seus efeitos suspensos até as deliberações finais de que tratam os $\S \S 2^{\circ}$ e $3^{\circ}$. O texto, como se nota, abrange todas as hipóteses de infração previstas no art. 55, e não apenas as dos incisos I e II desse artigo, que provocam a inelegibilidade referida no art. $1^{\circ}, \mathrm{I}, b$, da lei da inelegibilidades. A remissão aos $\S \S 2^{\circ}$ e $3^{\circ}$ do art. 55 significa que a medida abrange tanto os processo que levam à extinção como os que conduzem à cassação do mandato, embora nem todos os casos resultem em 
Resulta dessa determinação constitucional o fato de que, enquanto submetido a um processo que vise ou possa levar à perda de seu mandato, o parlamentar pode e até tem todo o direito de levar a termo seu pedido de renúncia, formalizando-o perante a respectiva Casa congressual a que pertencer; porém, essa manifestação só surtiria os devidos efeitos de direito (eficácia) após o término do processo, ficando suspenso durante esse período. Saliente-se, ainda, que a renúncia só tem eficácia após a sua publicação.

Cumpre ressaltar que o texto da Constituição fala em "processo que vise ou possa levar à perda de mandato", e isso significa que, de início, o processo não precisa estar direcionado à aplicação da sanção de perda de mandato, basta ser processo ético-disciplinar que busque a aplicação de qualquer outra penalidade, por exemplo, a de suspensão de prerrogativas ou de censura verbal. Importa que, ao final do processo, sempre haverá a possibilidade de reenquadramento da penalidade de início proposta, podendo ser indicada a aplicação de punição mais grave. Não poderá, então, o acusado em processo ético-disciplinar renunciar, alegando que o processo não tinha o intuito de cassar o seu mandato, mas apenas de impor sanções de natureza leve, pois sempre será possível a decretação da perda de mandato, uma vez que esteja instaurado processo ético-disciplinar.

Questão relevante, então, é especificar em que momento o parlamentar pode ser submetido a processo que vise ou possa levar à perda do mandato, de modo a ser aplicável a ele os ditames do art. $55, \S 4^{\circ}$, da Constituição, impedindo que sua eventual renúncia surta efeito. Primeiro, impende dizer que o ato de provocação do processo de cassação por quebra de decoro parlamentar, promovido pela Mesa da respectiva Casa legislativa a que pertencer o parlamentar ou por partido político, não induz imediatamente a instauração do processo, o que significa que a representação é, de fato, mero pedido direcionado ao Conselho para que apure e indique a punição de determinada conduta, que por si só não instaura o processo.

A ideia central que fundamenta a competência da Mesa de cada uma das Casas legislativas e do partido político com representação no Congresso Nacional para provocar a instauração do processo de cassação de mandato por quebra de decoro é a de que nenhuma decretação de perda de mandato será realizada sem a manifestação de uma dessas duas esferas

inelegibilidade (SILVA, José Afonso da. Curso de direito constitucional positivo. São Paulo: Malheiros, 2007, p. $541)$. 
institucionais, é essa uma condição de admissibilidade e procedibilidade da representação ofertada contra o agente parlamentar acusado.

Com certeza, essa interpretação exposta anteriormente não agradará os defensores da "moral a qualquer custo", uma vez que se fundamenta em uma compreensão estritamente formal do direito, isto é, para determinar o momento em que o processo é efetivamente instaurado, lança-se o olhar analítico para o modo como foi formalmente enfrentada a questão nas normas constitucionais e infraconstitucionais. Com efeito, qualquer denúncia contra parlamentar protocolada por cidadão junto a algum órgão do Parlamento, ainda que haja provas inequívocas da quebra de decoro, não tem o condão de evitar que a renúncia ao mandato produza seus devidos efeitos, impedindo, consequentemente, o julgamento jurídicopolítico em processo de cassação. Isso também ocorre se for instaurada em qualquer instância do Parlamento sindicância para apurar certas situações de desvio ético que envova um de seus membros. Corroborando este entendimento, temos o seguinte trecho de autoria do Ministro Carlos Ayres, emitido em julgado do Supremo Tribunal Federal:

Esta a pergunta que verdadeiramente conta: os impetrantes se achavam na condição de pessoas processualmente acusadas perante a Corregedoria da Câmara? E perante a respectiva Mesa, quando da aprovação e encaminhamento do mesmo parecer à Comissão de Ética e Decoro, tal condição subjetiva era de pessoas processualmente acusadas? A resposta me parece negativa. Ainda não havia acusados (como até agora não há), pois tal qualificação subjetiva começa é com a abertura de processo disciplinar na instância para esse fim concebida: o Conselho de Ética e Decoro Parlamentar. Conselho nominado e regulado pelo artigo $6^{\circ}$ do Código de Ética e Decoro Parlamentar da Câmara dos Deputados para, justamente, processar pessoas investidas no cargo de Deputado Federal. (Supremo Tribunal Federal, MS 25.594/DF, Rel. Min. Carlos Britto, $D J$ de 20.10.2005.) [Grifo nosso.]

Vê-se, dessa maneira, que o processo ético-disciplinar propriamente dito só passa a existir conforme seja instaurado formalmente pelos Conselhos de Ética e Decoro Parlamentar das Casas legislativas. Com efeito, temos que, na Câmara dos Deputados, a abertura do processo é feita no momento em que o presidente do Conselho de Ética recebe a representação acusatória formulada pela Mesa ou pelo partido político com representação no Congresso, isso a teor do art. 14, $\S 4^{\circ}$, I, do Código de Ética, o qual estabelece que, ao ser recebida a representação pelo presidente do Conselho, este designará o relator, e do art. $7^{\circ}$ do 
Regulamento Interno do Conselho, que impõe a instauração imediata do processo quando de seu recebimento pelo presidente. A partir desse momento, então, o deputado se torna acusado ou representado, estando impedido de renunciar ao mandato nos termos do art. $55, \S 4^{\mathrm{o}}$, da Constituição. Teceremos maiores considerações posteriormente, quando tratarmos das formas de instauração dos processos nos Conselhos.

No que concerne ao Código de Ética do Senado Federal, este traz regra mais clara quanto ao tema, ao dispor, em seu art. 15-A, que o processo é instaurado por decisão do Conselho quando considerar que há indícios de prática de ato que possa sujeitar o senador à perda do mandato; todavia, o $\S 4^{\circ}$ do artigo dita que, para fins do disposto no art. $55, \S 4^{\circ}$, da Constituição, considera-se instaurado o processo a partir da publicação da decisão no Diário do Senado Federal. Observe-se que, no Senado, há um momento próprio para a tomada dessa decisão pelo Conselho, o qual não se confunde com o despacho do presidente realizado no recebimento da representação, como ocorre na Câmara.

Diante dessa perspectiva, é importante ressaltar a possibilidade de se tomar outro caminho analítico, argumentando que o processo propriamente dito só existe após o aperfeiçoamento da relação processual, isto é, depois de o representado receber a intimação quanto à existência do processo.

Obviamente, ao adotarmos uma posição formalista quanto ao momento da abertura do processo de cassação, alguns problemas surgem. Nesse sentido, constatamos que os acontecimentos políticos que têm impacto potencial à dignidade parlamentar são, em regra, conhecidos pelo público muito antes que o ambiente político institucional possa tomar quaisquer providências para averiguar a questão. Isso impõe imensos desafios para a dinâmica do mundo político. Assim, antes mesmo que se possa elaborar qualquer representação diante de ofensa ao decoro parlamentar e apresentá-la formalmente ao órgão responsável pela instauração do processo de cassação, o membro do Senado ou da Câmara pode renunciar, causando, de fato, um dano dobrado ao Poder Legislativo quanto à sua imagem, uma vez que, para a opinião pública em geral, tal situação redundará em um sentimento de injustiça e impunidade pela não aplicação da punição política cabível.

Talvez, por essa razão, o Decreto Legislativo n. 16/94 dispôs que: 
Art. $1^{\circ} \mathrm{A}$ renúncia de parlamentar sujeito à investigação por qualquer órgão do Poder Legislativo, ou que tenha contra si procedimento já instaurado ou protocolado junto à Mesa da respectiva Casa, para apuração das faltas a que se referem os incisos I e II do art. 55 da Constituição Federal, fica sujeita à condição suspensiva, só produzindo efeitos se a decisão final não concluir pela perda do mandato. Parágrafo único. Sendo a decisão final pela perda do mandato parlamentar, a declaração da renúncia será arquivada. [Grifo nosso.]

Cumpre destacar que esse texto do Decreto Legislativo transcrito, embora inspirado no art. 55, $\S 4^{\circ}$, da Constituição, afasta-se de seus termos na medida em que determina a suspensão dos efeitos da renúncia não só quando houver processo que vise ou possa levar à perda do mandato mas também para os casos em que haja senador ou deputado submetido à investigação promovida por qualquer órgão do Poder Legislativo. Resulta dessa situação normativa que mera sindicância ou procedimento investigativo instaurado por qualquer órgão interno do Poder Legislativo tem o efeito de suspender a eficácia de eventual pedido de renúncia de mandato até que ocorra decisão final do procedimento. Busca-se, dessa forma, fechar o cerco ao parlamentar que tenha o intuito de fugir de suas responsabilidades perante seus pares. Como já salientamos, essa necessidade de evitar que o parlamentar renuncie ao mandato e submeta-se ao julgamento de seus pares está posta tendo em vista que, no processo de cassação, conforme os termos definidos pelo art. 55, § $2^{\circ}$, o parlamentar não só perde status de representante político mas também passa a ter sua esfera de cidadania limitada pelo fenômeno da inelegibilidade.

Pela análise realizada, poderíamos discutir se o Decreto Legislativo teria competência para ampliar aquilo que a Constituição estabeleceu, mas nos parece que essa discussão seria de alguma forma estéril, já que, atualmente, encontramos a seguinte redação na Lei Complementar n. 64/90, alterada pela Lei Complementar n. 135/2010 (conhecida como Lei da Ficha Limpa):

Art. $1^{\circ}$ São inelegíveis: I

$[\ldots]$

k) o Presidente da República, o Governador de Estado e do Distrito Federal, o Prefeito, os membros do Congresso Nacional, das Assembleias Legislativas, da Câmara Legislativa, das Câmaras Municipais, que renunciarem a seus mandatos 
desde o oferecimento de representação ou petição capaz de autorizar a abertura de processo por infringência a dispositivo da Constituição Federal, da Constituição Estadual, da Lei Orgânica do Distrito Federal ou da Lei Orgânica do Município, para as eleições que se realizarem durante o período remanescente do mandato para o qual foram eleitos e nos 8 (oito) anos subsequentes ao término da legislatura...

Conforme se vê, a Lei Complementar n. 64/90 declara como inelegível o membro do Congresso Nacional que renunciar a seu mandato desde o oferecimento de representação ou petição capaz de autorizar a abertura de processo por violação a dispositivo da Constituição Federal, isto é, a renúncia ao mandato quando da existência de qualquer tipo de acusação formalizada contra membro do Poder Legislativo, independentemente de constituir instauração de processo ético-disciplinar ou não, é hipótese de inelegibilidade. Não fere esse dispositivo o art. $55, \S 4^{\circ}$, da Constituição, já que não versa sobre hipótese de suspensão dos efeitos da renúncia, mas, sim, de competência que lhe é própria.

\subsubsection{Motivo}

Para que o processo de cassação de mandato parlamentar seja instaurado, é necessário que o motivo - isto é, o fato passível de ser apreciado como ofensivo à dignidade do Poder Legislativo - tenha efetivamente ocorrido. A existência do fato é, assim, essencial. Não é possível iniciar processo que vise decretar a perda de diante de comportamento cuja ocorrência já se encontra de início afastada. Exempli gratia, não se pode deliberar sobre a perda de mandato de deputado ou senador fundamentando a decisão em desvio de verba pública que não aconteceu.

5.1.3.1 Princípio da unidade da legislatura e processo de cassação

A existência concreta do motivo, isto é, do fato potencialmente ofensivo ao decoro como quesito a ser preenchido para a provocação e a instauração do processo de cassação de 
mandato parlamentar impõe alguns desafios de análise, principalmente no que diz respeito ao tempo de sua constatação diante do período de certa legislatura. Poderíamos iniciar nossa discussão indagando de forma ampla e genérica se, para a instauração do processo de cassação de mandato, nos termos do art. 55, II, $\S 2^{\circ}$, da Constituição, há alguma relevância em se questionar o momento em que o fato lesivo à dignidade institucional tenha ocorrido, melhor dizendo, se existe algum elemento temporal quanto à ocorrência do motivo que possa obstaculizar a instauração do processo. Parece-nos, entretanto, prudente desenvolver nossa análise a partir de uma situação mais específica.

Impende, então, "imaginar" a seguinte circunstância: no decorrer de determinada legislatura, um parlamentar comete ato claramente violador das normas de decoro, ferindo o art. 55, II, da Constituição; no entanto, por motivos alheios à vontade dos membros da respectiva Casa a que pertence, acaba não sendo levado a julgamento perante seus pares nos termos do art. 55, $\S 2^{\circ}$, da Constituição. Em adendo, no momento subsequente ao término da legislatura, esse mesmo parlamentar, que acabou não sendo julgado por seus pares, candidatase e é reeleito para novo período de mandato. Então, pergunta-se, pode a Casa legislativa a que pertence o parlamentar cassar seu mandato com fundamento em situação ocorrida durante a legislatura anterior? Não se discute, como se vê, a existência ou inexistência da conduta indigna do parlamentar - de fato, uma vez ocorrida a ofensa ao decoro, não há lapso temporal que a faça desaparecer.

No caso, temos duas legislaturas que estão mediadas por um momento eleitoral no qual os cidadãos, no exercício de seu direito político (ativo), ditam a sua vontade nas urnas, reconduzindo o autor da conduta imoral a um novo mandato representativo na esfera do Parlamento. Entre uma legislatura e outra há uma decisão política soberana do cidadão eleitor. Considerando, pois, esse aspecto importante, seria possível aos demais representantes eleitos da Casa legislativa julgar a conduta ofensiva ocorrida durante o exercício do mandato anterior?

Uma primeira resposta possível seria a de que, uma vez finda a legislatura, se exaure a competência da Casa legislativa para apreciar o comportamento de um de seus membros que porventura tenha cometido faltas éticas. Indicaria tal argumento que a legislatura tem um caráter uno, de modo que todas as situações que ocorreram sob seu influxo devem ser resolvidas no seu espaço temporal respectivo. Assim, uma nova legislatura inauguraria uma 
nova unidade de tempo que não guardaria relação com a legislatura anterior. Estaríamos diante do que a doutrina tem nomeado de princípio da unidade da legislatura. Este seria o critério definidor da competência temporal para a apreciação da conduta parlamentar e sua punição política. Oportuno, contudo, desde já afastarmos essa forma interpretativa, adotando a posição do Ministro Celso de Mello em julgado do Supremo Tribunal Federal:

Cabe destacar, neste ponto, que o princípio da unidade de legislatura - que faz cessar, a partir de cada novo quadriênio, todos os assuntos iniciados no período imediatamente anterior, dissolvendo-se, desse modo, todos os vínculos com a legislatura precedente (JOSÉ AFONSO DA SILVA, "Princípios do Processo de Formação das Leis no Direito Constitucional", p. 38/39, item n. 14, 1964, RT) - rege, essencialmente, o processo de elaboração legislativa, tanto que, encerrado o período quadrienal a que se refere o art. 44, parágrafo único, da Constituição Federal, dar-se-á, na Câmara dos Deputados, o arquivamento das proposições legislativas, com a só exceção de alguns projetos taxativamente relacionados na norma regimental (Regimento Interno da Câmara dos Deputados, art. 105). É por essa razão que o eminente Professor JOSÉ AFONSO DA SILVA, ao tratar do postulado da unidade de legislatura, examina-o dentre os princípios que informam o processo constitucional de formação das leis. [...] o princípio da unidade de legislatura não representa obstáculo constitucional a que as Casas legislativas venham, ainda que por fatos anteriores à legislatura em curso, a instaurar - contra quem já era titular de mandato na legislatura precedente - procedimento de caráter políticoadministrativo, destinado a viabilizar a decretação da perda do mandato, por fato atentatório ao decoro parlamentar, cometido por quem então se achava investido na condição de membro de qualquer das Casas do Congresso Nacional (CF, art. 55, I, "e", $\S \S 1^{\circ}$ e $2^{\circ}$ ). (Supremo Tribunal Federal, MS 24.458 MC/DF - Rel. Min. Celso de Mello, DJ de 21.02.2003.)

Em outro julgado, o Ministro Néri da Silveira tratou a questão de modo semelhante:

Sustenta-se que a cassação do mandato, para nova legislatura, fica restrita à hipótese de, no curso dessa legislatura, se verificarem condutas, dela contemporâneas, capituláveis como atentatórias do decoro parlamentar. [...] Tese invocada, acerca da inexistência de contemporaneidade entre o fato típico e a competência da atual legislatura, que se rejeita. (Supremo Tribunal Federal, MS 23.388-5 DF, Rel. Min. Néri da Silveira, DJ de 20.04.2001.)

No bojo do processo citado, houve manifestação importante do Presidente da Câmara dos Deputados corroborando a tese ora sustentada. O relator Ministro Néri da Silveira assim transcreve parte dessa manifestação: 
... Destarte, nada obsta que Deputado, autor de atos atentatórios ao decoro parlamentar em determinada legislatura, possa responder a procedimento disciplinar destinado à perda de seu mandato em legislatura subsequente, para a qual se reelegeu; isto porque o dano à imagem do corpo legislativo, de ter no seu seio autor de fato indecoroso, persiste íntegro, independente da legislatura em que foi praticado aquele ato. $\mathrm{Na}$ verdade, tendo os atos atentatórios ao decoro parlamentar, imputados ao Impetrante, ocorrido a partir de meados de outubro de 1998 (item 2 da inicial), ou seja, após as eleições realizadas no dia 04 daquele mês e ano, é certo que o seu eleitorado não teve a menor oportunidade de fazer qualquer julgamento sobre sua conduta, como quer fazer crer. (Supremo Tribunal Federal, MS 23.388-5 DF, Rel. Min. Néri da Silveira, DJ de 20.04.2001.)

Por tudo o que registramos anteriormente, mostra-se a inconsistência da tese de que o princípio da unidade da legislatura impede a instauração do processo de cassação de mandato parlamentar previsto no art. 55, II, $\S 2^{\circ}$, da Constituição, quando a conduta objeto do processo tiver lugar durante o exercício de mandato em legislatura anterior. $\mathrm{O}$ referido princípio diz respeito tão somente ao processo de formação de lei, não àquele que vise à aplicação de penalidades políticas. Nesses termos, José Eduardo Martins Cardozo pondera que:

Seria, pois, rigorosamente incorreto imaginar-se que, ao término de uma legislatura, os atos desabonadores praticados por um parlamentar, por mais graves e hediondos que fossem, estivessem sempre juridicamente impedidos de ser apreciados pelo Parlamento para fins de que se pudesse vir a decretar a cassação do seu mandato nos termos do art. 55, II, da Constituição Federal. $^{294}$

Após essas análises, todavia, outra questão importante deve ser suscitada: se por um lado, como vimos, o princípio da unidade da legislatura não interfere na possibilidade da instauração do processo de cassação de mandato; por outro, considerando a circunstância de um parlamentar reeleito para novo mandato e que tenha cometido conduta indecorosa em legislatura anterior, a decisão política popular teria, nesse caso, algum reflexo na possibilidade de abertura do processo durante essa nova legislatura. Ora, a decisão que cassa um mandato parlamentar tem um caráter político, mas, na mesma medida, a decisão de eleger determinado

${ }^{294}$ CARDOZO, José Eduardo Martins. Consulta n. 001/2007, cit., p. 26. 
membro do parlamento também perfaz uma decisão política. Entre uma legislatura e outra ocorre a decisão popular por meio do voto. Se a Casa congressual, por motivo que lhe seja alheio, não instaura o processo e pune a conduta do parlamentar faltoso com seus deveres éticos durante a legislatura em que esse comportamento teve lugar, e posteriormente esse membro do Poder Legislativo é reeleito para novo mandato, estaria seus pares durante essa nova legislatura autorizados a desfazer a decisão popular? Essa questão é tão interessante quanto complexa.

Por certo, a decisão política do cidadão realizada em contexto de competição eleitoral tem fundamento no princípio da soberania popular, teor inconteste do art. $1^{\circ}$, parágrafo único, da Constituição, de modo que, se o povo deseja que determinado parlamentar tenha assento garantido no Poder Legislativo, essa decisão tem um peso inexorável, principalmente quando comparada à decisão que decreta a perda de mandato nos termos do art. $55, \S 2^{\circ}$, da Constituição, a qual se caracteriza como uma decisão secundária (feita por representantes eleitos) e excepcional, aplicável somente em casos limites, como na hipótese em que há quebra do decoro parlamentar capaz de ameaçar a efetividade das instituições democráticas. Estaria, então, a eleição apta a reabilitar o parlamentar para o exercício de novo mandato, impedindo que seus pares apreciem conduta perpetrada em legislatura anterior?

Quanto a esse ponto, adotamos o posicionamento de José Eduardo Martins Cardozo, para quem "o voto popular não pode ser visto como uma forma anômala de anistia política"; ${ }^{295}$ no entanto, "não pode ser ignorado sempre, e em qualquer caso, na possibilidade de aplicação da pena de cassação em decorrência de fato ocorrido ao longo de mandato anterior já extinto". ${ }^{296}$ Com efeito, antes, é preciso verificar em que conjuntura política se deu a decisão popular, considerando o próprio conhecimento público da conduta do parlamentar que porventura tenha violado as regras de decoro institucional. Assim, em algumas situações, será nítido que o voto popular obsta a instauração de processo de cassação de mandato, uma vez que o fato indecoroso era de conhecimento amplo do público, o que significa dizer que, mesmo sabendo dos comportamentos do candidato, o cidadão eleitor optou por reconduzir o ex-parlamentar para mais um mandato. Se na legislatura anterior este cometeu atos imorais ou indignos, o povo considerou que tal situação não foi tão grave assim, de modo que o reelegeu.

${ }^{295}$ CARDOZO, José Eduardo Martins. Consulta n. 001/2007, cit., p. 33.

${ }^{296}$ CARDOZO, José Eduardo Martins. Consulta n. 001/2007, cit., p. 33. 
$\mathrm{Na}$ decisão que elege determinado parlamentar, é preciso supor que foi apreciada a conduta indecorosa. Obviamente, isso é uma ficção, pois não é possível constatar objetivamente esse direcionamento da decisão do cidadão, já que, no momento eleitoral, são muitos os fatores que pesam na tomada de decisão pelo eleitor.

Em sentido inverso, contudo, devemos considerar que a reeleição, ou seja, o exercício da soberania popular, não impede a cassação do mandato por quebra de decoro quando a opinião pública não teve tempo suficiente de tomar conhecimento da conduta do agente parlamentar ou essa conduta simplesmente não era conhecida ao tempo do pleito eleitoral, de modo que não foi considerada no momento da escolha realizada nas urnas pelo eleitor. A título de exemplo, podemos imaginar um parlamentar filmado desviando recursos públicos durante o exercício de uma legislatura, mas cujo conhecimento do vídeo só viesse a público a partir de legislatura subsequente, na qual ele foi reeleito. Nesse caso, é mais do que nítida a possibilidade de ter seu mandato cassado, nos termos do art. 55, II, da Constituição, já que a população e muito menos seus pares tinham qualquer conhecimento da situação anterior. É essa precisamente a linha de raciocínio adotada por José Eduardo Martins Cardozo, que reproduzimos a seguir:

... por força do princípio democrático está juridicamente impedido o Parlamento de cassar, por falta de decoro, aquele parlamentar reeleito cuja acusação se prende a fato verificado em legislatura anterior, já conhecido plenamente no momento da eleição, desde que não tenha ocorrido após o resultado das urnas qualquer mudança fática ou de conhecimento em relação aos fatos, que pudesse alterar, ao menos em tese, a convicção do eleitorado. [...] pode o Parlamento decidir pela cassação de mandato parlamentar em decorrência de fato ocorrido em mandato anterior já extinto, sem qualquer constrangimento em relação ao voto popular dado nas urnas, desde que novos elementos fáticos, de convicção ou de prova surjam em relação àquele mesmo fato original após o momento eleitoral. Estes novos elementos terão que produzir a convicção política de que a sua ocorrência seria capaz de, em tese, modificar o posicionamento do eleitor no momento da escolha eleitoral. ${ }^{297}$

Observe-se que, se uma circunstância imoral envolvendo conduta de certo parlamentar é amplamente conhecida antes das eleições e, mesmo assim, este é reeleito para novo mandato, está posto um obstáculo para a instauração do processo de cassação de seu mandato,

\footnotetext{
${ }^{297}$ CARDOZO, José Eduardo Martins. Consulta n. 001/2007, cit., p. 37-38.
} 
não podendo os demais representantes do povo substituir a vontade das urnas pelas suas. Convém, todavia, verificar que esse mesmo fato pode ganhar outros contornos após a eleição, tendo em vista novos elementos fáticos desconhecidos à época do pleito, de modo a possibilitar que os membros da Casa legislativa do representante reeleito cassem seu mandato, uma vez que deve se supor que, se os fatos fossem totalmente conhecidos em seus pormenores no momento da eleição, os eleitores talvez não tivessem votado da mesma maneira.

\subsubsection{Contemporaneidade da conduta com o exercício do mandato}

Até aqui, analisamos a existência do ato ofensivo ao decoro como um comportamento passível de ser levado a efeito somente por quem está na condição jurídica de agente político parlamentar, isto é, por quem, no momento da conduta, é membro de uma Casa Legislativa. Anteriormente, estudamos a questão da legitimidade de punição política de parlamentar, em determinada legislatura, por conduta imoral ocorrida em exercício de mandato durante legislatura posterior. Em nenhum momento, porém, se levantou a possibilidade de que alguém que não fosse agente parlamentar pudesse quebrar o decoro institucional do Poder Legislativo. Resta, então, perguntarmo-nos se a contemporaneidade da conduta com o exercício do mandato é um requisito para a abertura do processo de cassação de mandato por quebra de decoro, nos termos do art. 55, II, $\S 2^{\circ}$, da Constituição. Em outras palavras, alguém que, no momento do procedimento incompatível com o decoro ou imoral não fosse agente titular de um mandato parlamentar pode, posteriormente, quando do ingresso como membro do Poder Legislativo, ser punido por essa conduta?

Devemos notar que o tema nunca foi enfrentado profundamente pela doutrina nem pela jurisprudência. De início, para elucidar essa interessante e intricada questão, é oportuno transcrevermos a seguinte passagem da lavra do Ministro Celso de Mello, parte de fundamento de julgado proferido no Supremo Tribunal Federal:

Parece revelar-se essencial, portanto, para os fins a que se refere o art. 55, $\S 2^{\circ}$, da Constituição da República, a existência de uma necessária relação de contemporaneidade entre a prática do ato contrário ao decoro parlamentar, de um lado, e o exercício do mandato legislativo, de outro, mesmo que o ato ofensivo à dignidade institucional do mandato (e, também, à honorabilidade 
do Parlamento) tenha ocorrido na legislatura imediatamente anterior, praticado por quem, naquele momento, já era integrante do Poder Legislativo. (Supremo Tribunal Federal, MS 24.458 MC/DF, Rel. Min. Celso de Mello, DJ de 21.02.2003.)

Com efeito, prega o nobre Ministro que não é possível falar-se em procedimento incompatível com o decoro institucional quando, no momento do ato, o agente não esteja sob o influxo do regime jurídico próprio aos membros do Poder Legislativo, ou seja, não esteja legitimamente no exercício de mandato parlamentar. Não importa se o ato violador dos preceitos éticos institucionais tenha seu lugar na esfera da vida pública ou privada do agente, mas, simplesmente, se, no exato momento da conduta, ele era membro do Congresso Nacional. Dessa conclusão resulta que, se após a eleição de determinado senador ou deputado, vier a público fato relacionado à sua condição de antes do exercício do mandato e que macule a imagem da instituição diante da opinião pública, nada poderá fazer os seus pares a respeito dessa circunstância. Isso significa que a contemporaneidade entre a conduta indigna e o exercício do mandato é condição para a instauração do processo de cassação de mandato.

Alguém indignado com essa interpretação, que leva o Poder Legislativo a se prostrar em um momento decisivo em que se requer punição exemplar de um de seus membros, poderia explorar o texto constitucional em busca de interpretação diversa e com certeza encontraria seus fundamentos. É dessa forma que o Deputado Carlos Sampaio, ao relatar o Processo n, 01/2011 no Conselho de Ética e Decoro da Câmara dos Deputados, elaborou tese contrária à ora exposta.

Ao analisar o $\S 1^{\circ}$ do art. 55 da Constituição, o Deputado Carlos Sampaio aduz:

\footnotetext{
Vê-se, portanto, que o legislador constituinte de 1988 não vinculou a obtenção de vantagem indevida à prática de ato ilícito, como fazia a Constituição de 1967. Por outro lado, ainda de forma diversa daquela prevista na Carta Constitucional revogada, não impôs qualquer limitação temporal para o recebimento da vantagem indevida [...] Percebe-se, portanto, que o texto da Carta Magna atual, ao contrário do que previa a Constituição de 1967, não mais exigiu que a vantagem recebida fosse obtida no exercício do mandato parlamentar e, tampouco, vinculou-a à prática de ato ilícito ou imoral. ${ }^{298}$ [Grifo nosso.]
}

${ }^{298}$ Parecer n. 01/2011 do Conselho de Ética e Decoro Parlamentar da Câmara dos Deputados, Rel. Dep. Carlos Sampaio, p. 33-34. Disponível em: <http://www2.camara.gov.br/a-camara/eticaedecoro/parecer-do-relatorrelatorio-e-voto-rep-01_2011-dep-jaqueline-roriz >. Acesso em: 20 jul. 2011. 
Como se constata, o trecho do relatório transcrito baseia-se em uma leitura fria do texto constitucional de 1988, contendo uma tendência interpretativa muito clara, a qual indica que não há explicitamente nele qualquer limitação temporal quanto à ocorrência da ofensa ética parlamentar. Assim, esta poderia ocorrer dentro ou fora do exercício do mandato, não sendo este um fato relevante; afinal, o art. 55, $\S 1^{\circ}$, da Constituição apenas indica que "é incompatível com o decoro parlamentar, além dos casos definidos no regimento interno, o abuso das prerrogativas asseguradas a membro do Congresso Nacional ou a percepção de vantagens indevidas". Não se fala, pois, de abuso ou vantagens indevidas percebidas no exercício do mandato. Bem verdade, a Constituição também não afirma o contrário, não diz que a regra do decoro é aplicável a quem, no momento da conduta, não é parlamentar. Vê-se, então, que a questão não se resolve pela simples leitura dos ditames constitucionais. É claro que o Deputado relator reconhece que o Código de Ética da Câmara dos Deputados determina, em seu art. $4^{\circ}$, que a quebra de decoro só tem lugar quando o agente está no exercício do mandato; todavia, argumenta que, nesse ponto, o texto regimental extrapola seus limites ao reduzir amplitude do texto constitucional. ${ }^{299}$

Como resta evidente, temos duas posições, uma que indica a necessidade de contemporaneidade entre a conduta ofensiva ao decoro e o exercício do mandato, e outra que sustenta tese inversa. Imperioso tomarmos posição. Parece-nos que, no caso, há realmente uma posição que é a mais razoável diante da Ordem Constitucional de 1988, e essa é a que pressupõe a contemporaneidade entre a conduta ofensiva ao decoro e o exercício do mandato para que seja possível a instauração do processo de cassação de mandato. Embora essa posição fragilize o Poder Legislativo quando frente a certas situações, isso não deve impedir que usemos muito mais nossa razão do que nosso desgosto com a política para tomar decisões dessa natureza. De fato, a busca da moralidade a qualquer custo pode gerar situações das mais aberrantes diante dos princípios mínimos do Estado Democrático de Direito. Não temos medo de firmar a presente tese, pois estamos cientes das responsabilidades que envolvem tal tomada de posição.

${ }^{299}$ Parecer n. 01/2011 do Conselho de Ética e Decoro Parlamentar da Câmara dos Deputados, Rel. Dep. Carlos Sampaio, p. 34. Disponível em: <http://www2.camara.gov.br/a-camara/eticaedecoro/parecer-do-relator-relatorioe-voto-rep-01_2011-dep-jaqueline-roriz>. Acesso em: 20 jul. 2011. 
Nesses termos, oportuno mais uma vez trazermos à baila as considerações precisas de José Eduardo Martins Cardozo, que, ao relatar o Processo n. 02/2007 junto ao Conselho de Ética e Decoro Parlamentar Câmara, afirma:

\begin{abstract}
Pretender que alguém que não era parlamentar quando da prática de um ato, após tornar-se parlamentar, possa ser punido por este mesmo ato a título de desrespeito às normas éticas de uma especial categoria de agentes públicos a que não pertencia, seria admitir-se uma estranha forma de retroatividade punitiva. Uma retroatividade não só ofensiva aos mais elementares princípios de direito, mas à própria lógica e ao bom senso. ${ }^{300}$
\end{abstract}

Essas análises enfatizam o disparate que seria cassar um mandato de determinado representante parlamentar por ato imoral ocorrido em momento no qual este não tinha a titularidade de qualquer mandato na esfera do Poder Legislativo. A conduta ética parlamentar é requisito para quem tem a condição de agente parlamentar. Não se está dizendo aqui que o comportamento imoral deixa de o ser por não ter ocorrido no decorrer do exercício de um mandato, mas, sim, que não poderá ser objeto de apreciação em processo de cassação de mandato por quebra de decoro.

De início, cabe ressaltar que a noção de decoro trazida pelo art. 55, II, da Constituição não constitui um requisito formal para se entrar em exercício do mandato, pois, se assim o fosse, estaríamos diante de uma regra similar às regras de inelegibilidades, ou seja, seria uma condição para o exercício do mandato, e não uma hipótese de perda do mandato por circunstâncias confirmadas posteriormente. Com efeito, o decoro parlamentar refere-se a um momento preciso, que é o do exercício do mandato. A violação de uma regra institucional se dá por quem tem as responsabilidades vinculadas à instituição. Nesse sentido, a perspectiva de retroagir as regras de decoro a ponto de atingir qualquer momento da vida do parlamentar perfaz muito mais um desejo de ordem moral do que uma análise jurídico-política ponderada.

Reconhecemos que nosso entendimento de que não se pode dar tamanha elasticidade temporal ao instituto do decoro parlamentar não é plenamente satisfatório, no sentido de cobrir todo e qualquer tipo de comportamento que macule a imagem institucional do parlamento.

\footnotetext{
${ }^{300}$ Parecer do Conselho de Ética e Decoro Parlamentar da Câmara dos Deputados, Representação n. 02/2007, Rel. Dep. José Eduardo Cardozo. Disponível em: <http://www2.camara.gov.br/a-camara/eticaedecoro/parecerrep-02-2007-raul-jungmann-rel.-jose-eduardo-cardoso >. Acesso em: 20 jul. 2011.
} 
Destarte, segundo a tese que defendemos, um senador ou deputado que cometa atos de moralidade grave durante período anterior ao exercício da função não poderá ser cassado nos termos do art. 55, II, da Constituição, ainda que o fato só venha a público em período subsequente, após assumir uma cadeira no âmbito do Legislativo. Nessa circunstância, não há dúvida de que a dignidade e o prestígio do Parlamento são atingidos, mas tal situação não basta para que a Casa a que pertence o parlamentar lhe casse o mandato utilizando-se do mecanismo do decoro.

Isso, com certeza, causará estranheza, já que claramente há aqui uma negação do próprio instituto da cassação de mandato por ofensa ao decoro, pois este existe constitucionalmente para proteger a imagem da instituição parlamentar visando garantir a efetividade institucional democrática do Estado. Mas a questão deve ser bem entendida: ao tratar ilimitadamente a possibilidade de aplicação do mecanismo de cassação de mandato por quebra de decoro, pode ocorrer que o efeito desejado não seja alcançado, gerando o seu reverso, qual seja, a deslegitimação do poder estatal. Conferir tamanho poder aos membros do parlamento para desfazer mandatos democráticos que são presumidamente legítimos parecenos ser um risco por demais excessivo.

Atentemos para o fato de que o instituto da cassação de mandato é medida política de cunho excepcional - a regra é de que a responsabilidade política se dê na relação primária de representação, no caso, entre povo e eleito, e não entre os eleitos. Por ser regra de natureza excepcional, a previsão do art. 55, II, da Constituição deve sempre ser interpretada de maneira restritiva, dando-se preferência para que o povo julgue a situação da melhor maneira. $\mathrm{O}$ regime democrático pressupõe a liberdade de manifestação e de informação exatamente para que as decisões políticas possam ser tomadas com amplo conhecimento público. Ademais, não devemos esquecer que a conduta do agente parlamentar que diga respeito a período anterior à titularidade de mandato pode ser enquadrada em outras espécies normativas, de modo a configurar outras hipóteses de punição. Inclusive, ressalte-se que, se houver prática de crime, ocorrendo condenação criminal com sentença transitada em julgado, o agente também poderá perder seu mandato em processo de cassação, com fundamento no art. 55, VI, da Constituição.

Reforce-se que, se existe um momento importante no qual a responsabilidade política pode ser realizada de forma ampla e irrestrita, é este o processo eleitoral; exceto isso, por todos os atos anteriores a exercício de qualquer mandato, responde o parlamentar na esfera de 
responsabilidade específica: penal, civil e administrativa. A ética é um requisito para todos que estejam no exercício de uma função pública e é um direito de todo cidadão ter governantes probos, mas isso não pode levar-nos, sob certa conjuntura política, a ser defensores de medidas irresponsáveis e não razoáveis diante do direito e do princípio democrático. Apenas o agente político parlamentar submete-se às normas do regime jurídico parlamentar e somente pode quebrar seus deveres quando no exercício do mandato, o que parece óbvio. Não é por outra razão que o Código de Ética e Decoro Parlamentar do Senado Federal traz a seguinte redação em seu art. $22, \S 1^{\circ}$ : "Ressalvados os casos previstos no inciso I do art. $3^{\circ}$ desta Resolução, a representação ou denúncia somente poderá abordar atos ou omissões no curso do mandato do representado ou denunciado".

Impende, então, firmarmos que é requisito para a instauração do processo de cassação do mandato, nos termos do art. 55, II, $\S 2^{\circ}$, da Constituição Federal, a contemporaneidade do mandato com o exercício do mandato.

\subsubsection{Da possibilidade de cassação de parlamentar licenciado}

O art. 56 da Constituição estabelece duas hipóteses de afastamento temporário do exercício efetivo da função legislativa nas quais o Deputado ou Senador não perde o respectivo mandato. A primeira dessas circunstâncias ocorre quando o parlamentar está investido no cargo de Ministro de Estado, Governador de Território, Secretário de Estado, do Distrito Federal, de Território, de Prefeitura de Capital ou chefe de missão diplomática temporária (art. 56, I, da Constituição Federal). A segunda diz respeito a parlamentar que se licencia da função por motivo de doença ou para tratar, sem remuneração, de interesse particular, desde que, nesse caso, o afastamento não ultrapasse cento e vinte dias por sessão legislativa (art. 56, II, da Constituição Federal). Nessas duas circunstâncias, por determinação constitucional, o agente político parlamentar não perde o mandato, mas fica afastado de seu exercício efetivo, ou seja, não atua na Casa parlamentar, ainda que continue a figurar como um titular de mandato. Ao contrário da situação que discutimos no tópico anterior, aqui há agente político eleito e submetido às regras estatutárias do congressista - existe, pois, o direito 
legítimo ao exercício do mandato; contudo, o senador ou deputado se afasta momentaneamente de suas incumbências na Casa congressual a que pertence.

De forma geral, essas duas hipóteses previstas nos incisos I e II do art. 56 da Constituição podem ser tratadas como licenças a que tem direito o congressista. Feitas essas considerações, impõe que indaguemos sobre a aplicabilidade das normas de decoro parlamentar a esses casos de licenciamento previstos constitucionalmente, isto é, enquanto afastado das funções para as quais fora eleito, o parlamentar (não o deixa de ser já que não perde o mandato) submete-se às sujeições e aos deveres éticos previstos em seu específico estatuto? Em suma, é permitido aos membros da Câmara dos Deputados e do Senado Federal abrir processo de cassação de mandato por quebra de decoro diante de conduta perpetrada por agente parlamentar durante licenciamento?

Tratemos separadamente os incisos do art. 56 da Constituição e comecemos pelo inciso II, no qual se prevê afastamento por motivos de saúde ou para tratar de assunto de interesse particular. Nesses casos, não nos parece haver dúvida de que o parlamentar licenciado fica submetido às regras de decoro previstas no regime jurídico do congressista, de modo que, se cometer qualquer deslize ético, poderá ter instaurado contra si, assim que retorne ao exercício efetivo da função, processo de cassação de mandato nos termos do art. 55, II, $\S 2^{\circ}$, da Constituição. Supor o contrário resultaria imaginar que ao parlamentar seria garantido positivamente na Constituição o direito de violar o seu texto.o próprio texto, já que toda vez que tivesse o intuito de realizar ato imoral e ofensivo à dignidade institucional bastaria solicitar uma licença para praticar a conduta; dessa forma, ao retornar à sua Casa legislativa, os seus pares estariam impedidos de lhe impor qualquer sanção, o que seria um verdadeiro absurdo. As regras de decoro, constituindo norma de moralidade, aplicam-se tanto à vida pública como à privada do parlamentar; de fato, quanto ao tempo do ato indecoroso, requer-se apenas que seja realizado em concomitância com o exercício de um mandato representativo. Se era parlamentar à época da conduta, pouco importa se foi no âmbito de sua atuação como congressista ou se no exercício de atividades privadas. Atingida a dignidade e o prestígio do Parlamento, está aberta a possibilidade da cassação.

O problema surge realmente quando analisamos o afastamento previsto no inciso I do art. 56 da Constituição, que permite o licenciamento do parlamentar para exercício de outra função política, isto é, o senador ou deputado não se retira do exercício efetivo do mandato 
para atuar na esfera de seus interesses particulares, mas para realizar outra atividade de caráter público político, como Ministro de Estado, Governador de Território, Secretário de Estado, do Distrito Federal, de Território, de Prefeitura de Capital ou chefe de missão diplomática temporária. Seria possível, nesse caso, cassar o mandato de parlamentar por quebra de decoro, tendo em vista procedimento ofensivo realizado enquanto licenciado para exercício das funções previstas no art. 56, I, da Constituição? Claro que, para responder a essa questão, não podemos recorrer aos mesmos argumentos arquitetados ao tratar da hipótese do inciso II do art. 56, pois aqui o conflito se dá em termos de regimes jurídicos políticos aplicáveis ao caso um membro do Congresso Nacional, enquanto vigente um mandato, submete-se às sujeições que lhe são específicas e que estão inseridas primariamente no texto constitucional, arts. 54 e 55. Quanto àqueles que exercem cargos políticos não parlamentares, estes estão submetidos a um regime de responsabilidade política que também é específico e não se confunde com o regime jurídico aplicável ao parlamentar. O exemplo mais evidente disso é o do Ministro de Estado quando comete ato violador da moralidade pública e por este pode ser punido por Crime de Responsabilidade, nos termos do art. 52, I, $a$, da Constituição.

Há, então, aqueles que argumentam que, uma vez afastado o parlamentar, nos termos do art. 56, I, da Constituição, fica este submetido às regras aplicáveis ao cargo que passa a exercer, implicando uma hipótese de não incidência do regime jurídico parlamentar, de modo que não pode ser punido pela Casa a que pertence por eventual quebra de decoro em decorrência de ato perpetrado enquanto licenciado. A conclusão seria a de que, enquanto afastado para o exercício de outra função pública de caráter político, não lhe são aplicáveis as regras de decoro parlamentar.

Nessa linha, encontramos o posicionamento do ex-Ministro Sepúlveda Pertence em julgado do Supremo Tribunal Federal, que discutia especificamente a possibilidade de a Câmara dos Deputados cassar mandato de parlamentar por quebra de decoro, tendo em vista uma conduta realizada enquanto o parlamentar estivera licenciado de sua função para exercício do cargo de Ministro de Estado. Embora posição vencida, importante transcrevermos a seguir os principais pontos das análises feitas pelo ex-Ministro:

... o Deputado - enquanto for Ministro de Estado - insere-se no regime político e jurídico de seu status ministerial, ao qual é mais que duvidoso se pudesse simultaneamente somar 
prerrogativas e responsabilidades da sua qualidade de congressista, inextricavelmente vinculadas ao exercício do mandato legislativo. [...] Não ignoro a diferença dos institutos, mas é indiscutível que as imunidades e prerrogativas, de um lado, e a sujeição à jurisdição censória da sua câmara, de outro, representam dados parciais do mesmo estatuto constitucional do titular do mandato eletivo: à primeira vista, pelo menos, não me convenço de que seja admissível cindilo, de modo a despir das imunidades o mandatário licenciado e, ao mesmo tempo, mantê-lo jungido ao estatuto de decoro da Casa a que não o protege, com as imunidades, da investida dos outros poderes. [...] É patente, de sua vez, que a cassação do mandato é uma modalidade de responsabilidade política do congressista; diverso, contudo, é o regime, também constitucional, da responsabilidade política do Ministro de Estado, pela comissão dos chamados crimes de responsabilidade, pelos quais responde, conforme a hipótese, perante o Supremo Tribunal Federal (Constituição Federal, art. 102, I, a) ou o Senado Federal (Constituição Federal, art. 52, I). De saber elementar, contudo, é que a punibilidade dos crimes de responsabilidade - sem prejuízo, é claro, da responsabilidade penal pelo mesmo fato -, cessa com o término da investidura do agente. [...] Não obstante, a cassação cogitada do mandato legislativo do impetrante, a pretexto de impor sanção à quebra do decoro parlamentar, teria verdadeiramente como motivo o seu comportamento como Ministro de Estado, artifício no mínimo esdrúxulo para ressuscitar a punibilidade já extinta de eventuais crimes de responsabilidade, que na mesma conduta se tivessem configurado. [...] Esse não é, todavia, o vício mais sério da cassação questionada, que surge, sim, das implicações da questão com o princípio fundamental da separação e independência dos poderes, de cuja positivação constitucional é parte integrante do regime de responsabilidade dos membros de cada um deles. [...] Ora, na medida em que se pudesse submeter alguém ao juízo censório da Câmara dos Deputados por fatos praticados no exercício da função de Ministro de Estado, estaria criado um mecanismo não tolerado pela Constituição de responsabilidade política póstuma de dignitários do Poder Executivo, por deliberação de uma das Casas do Congresso Nacional. (Supremo Tribunal Federal, MS 25.579/DF, Rel. Min. Sepúlveda Pertence, DJ de 24.08.2007.)

Dois aspectos são interessantes nos argumentos tecidos pelo ex-Ministro Sepúlveda Pertence: o primeiro diz respeito à pressuposição de que o regime jurídico parlamentar configura uma unidade fechada de prerrogativas e sujeições que só podem refletir de maneira completa e total na esfera do agente político, o que significa dizer que não poderia haver cisões dessas prerrogativas e sujeições parlamentares. Nesse caso, ou se está sob seu influxo total, submetendo-se ao Estatuto do Congressista como um todo, ou não se poderia aventar a possibilidade de se aplicar apenas em parte tal estatuto. Dando fundamento a essa interpretação, o próprio ex-Ministro lembra que a Súmula n. 04 do STF, que garantia a 
prerrogativa da imunidade parlamentar ao congressista nomeado Ministro de Estado, havia sido cancelada, de modo que seria de supor a inaplicabilidade do regime jurídico parlamentar nesses casos. ${ }^{301} \mathrm{O}$ parlamentar afastado com fundamento no inciso I do art. 56 da Constituição não tem sequer as prerrogativas dos membros do Poder Legislativo nem se submete às suas sujeições.

O segundo aspecto que importa notar é o argumento de que haveria ofensa ao princípio da separação de poderes se um membro no exercício de função política no Executivo pudesse ser punido pelo Legislativo em decorrência de seus atos. Parece-nos, nesse ponto específico, sem procedência o argumento. Convém, então, observar que os pontos de vista expostos aqui não foram suficientes para convencer a maioria do Supremo Tribunal de que a Câmara ou o Senado não poderia cassar mandato de um de seus membros após este ter cometido atos indecorosos no exercício do cargo de Ministro de Estado. Atualmente, a posição do Supremo Tribunal Federal é no sentido de que o afastamento de parlamentar, com fundamento no art. 56, I, da Constituição, não tem o condão de afastar possibilidade de sua responsabilização perante seus pares em processo de cassação de mandato por quebra de decoro.

Nesse sentido, o Ministro Gilmar Mendes, ao se manifestar no Mandado de Segurança n. 25.579/DF, rebate os argumentos do Ministro Relator Sepúlveda Pertence, sustentando, de início, que não reflete uma realidade jurídica o entendimento de que um membro do parlamento licenciado para exercício de função política nos termos do art. 56, I, não possa gozar de prerrogativas inerentes ao status parlamentar. O exemplo típico é o membro do Congresso que se licencia para exercer cargo de Secretário de Estado, pois, nessa circunstância, ele continua a ter a prerrogativa de foro privilegiado garantida a deputados e senadores, independentemente de estar ou não em exercício efetivo do mandato na esfera do Poder Legislativo. Sustentando essa análise, o Ministro Gilmar Mendes transcreve ementa do Inquérito n. 777:

Inquérito penal. Foro por prerrogativa de função. Deputado licenciado para exercer cargo de Secretário de Estado. - No sistema da Constituição Federal, a proteção especial a pessoa do parlamentar, independentemente do exercício do mandato, reside no foro por prerrogativa de

\footnotetext{
${ }^{301}$ Eis o teor da referida Súmula: "Não perde a imunidade parlamentar o congressista nomeado Ministro de Estado" (Cancelada no julgamento do Inqu104 RTJ-99/477 - 26.08.1981).
} 
função que lhe assegura o artigo 53, parágrafo $4^{\circ}$, da Carta Magna, ainda quando afastado da função legislativa para exercer cargo público constitucionalmente permitido. Questão de ordem que se resolve com a rejeição da preliminar de incompetência do Supremo Tribunal Federal levantada pela Procuradoria-Geral da República. (Supremo Tribunal Federal, Inq. N. 777 QO/TO, Rel. Min. Moreira Alves, DJ de $1^{\circ}$.10.1993.)

Observe-se, então, que o parlamentar licenciado nos termos o inciso I do art. 56 da Constituição pode usufruir privilégios tipicamente garantidos aos membros do Poder Legislativo. Considerando esse argumento, toda razão tem o Ministro Gilmar Mendes. Com efeito, nosso entendimento geral a respeito do tema é o de que as prerrogativas parlamentares existem em razão do combate político, principalmente em relação aos outros poderes instituídos na Constituição. Servem, assim, para garantir a independência da atuação parlamentar na busca do interesse público, como já deixamos bem assentado na trilha de nosso estudo. Por seu turno, as sujeições parlamentares de cunho ético dizem respeito à integridade do Poder Legislativo, são regras requeridas a todo aquele que tenha legitimidade para, a qualquer momento, exercer o mandato em sua esfera. Conveniente verificar que hoje não seria surpresa se um parlamentar deixasse temporariamente o exercício do cargo de Ministro para compor votações importantes no Congresso visando defender interesse do governo de que participa, isto é, ele poderia oscilar entre o exercício efetivo do mandato e do cargo ministerial conforme oportuno.

De fato, o membro do parlamento que se licencia nos termos do art. 56, I, da Constituição é alguém que reconhecidamente participou de eleição, recebeu votos e não perdeu o mandato quando foi exercer o outro cargo público, conforme dita a própria Constituição no caput do art. 56. Então, por que motivo se levantaria a possibilidade de o mesmo não se submeter às regras do decoro parlamentar?

Aliás, é preciso atentar ainda para a seguinte circunstância levantada pelo Ministro Carlos Ayres no Mandado de Segurança n. 25.579/DF:

Vejam como a questão que nos é colocada sob o nosso prudente julgamento é delicada. O art. 15 da Lei n. 1.049 diz o seguinte: “Art. 15. A denúncia só poderá ser recebida enquanto o denunciado não tiver, por qualquer motivo, deixado definitivamente o cargo. [...]" Vejam que coisa delicada, parece uma pecinha de cristal: se o parlamentar Ministro se desinveste do cargo de Ministro, retorna à sua Casa parlamentar, cometeu um crime enquanto Ministro e se não 
puder - no caso de falta de decoro - ser cobrado pelo parlamento, ele não poderá ser julgado por nenhum dos dois.

Da passagem anterior é possível constatar que, sob a ótica do legislador constitucional ou infraconstitucional, nunca houve o intuito de dar vida jurídica a sistemas de responsabilidades políticas estanques, compartimentadas e absolutas. A questão aqui se coloca no plano das relações políticas fáticas; nesse sentido, a Ordem Constitucional reconhece o parlamentar licenciado com fundamento no art. 56, I, como um titular de mandato político parlamentar, embora não o exerça. Sabe-se, por óbvio, que este pode retornar à sua Casa legislativa de origem quando oportuno, mas essa possibilidade de retorno não configura mera expectativa, e sim uma faculdade que o parlamentar exerce quando politicamente conveniente.

Enfatizando ainda mais o nosso posicionamento, o Ministro Celso de Mello se manifesta da seguinte forma no Mandado de Segurança n. 25.579/DF:

O membro do Congresso Nacional - que se licencia para exercer determinados cargos no Poder Executivo (como o de Ministro de Estado), podendo, até mesmo, como já assinalado, optar pela remuneração do mandato legislativo - não se desvincula da Casa a que pertence, pois, embora temporariamente afastado do exercício da função congressual, não rompe os laços que o unem, organicamente, ao Parlamento, tanto que continua a subsistir, em seu favor, a garantia constitucional da prerrogativa de foro em matéria penal... (Supremo Tribunal Federal, MS 25.579/DF, Rel. Min. Sepúlveda Pertence, DJ de 24.08.2007.) [Grifo nosso.]

Resulta de todo esse enredo de argumentos o fato de que, se um congressista, durante o período em que estiver licenciado nos termos do art. 56, I, da Constituição, cometer qualquer conduta que ofenda a dignidade e a honorabilidade do Poder Legislativo, poderá, assim que retornar à sua Casa de origem, ter decretada a perda de seu mandato por meio de processo de cassação fundamentado no art. 55, II, $\S 2^{\circ}$, da Constituição. Como salienta Eduardo Fortunato Bim: "Admitir que o afastamento para assumir funções executivas exime o parlamentar de se comportar com decoro seria negar a própria condição de parlamentar, fato inocorrente, uma 
vez que a Constituição fala em afastamento, e não em renúncia do mandato ou aposentadoria compulsória". 302

Cabe também refutar qualquer interpretação no sentido de que ocorre, nesses casos, violação do princípio constitucional da separação de poderes, já que o processo de cassação só é instaurado quando o membro do parlamento tomar assento na sua respectiva Casa parlamentar. Assim, tem-se que a cassação se dá por meio de uma relação entre pares de um mesmo poder, que é o Legislativo.

Por fim, ressaltemos, mais uma vez, que essa é a atual posição do Supremo Tribunal Federal, sustentada por votação majoritária no julgamento do Mandado de Segurança n. 25.579/DF.

\subsection{Do Conselho de Ética e Decoro Parlamentar}

A tramitação de um processo de cassação de mandato por quebra de decoro envolve a compreensão do papel dos Conselhos de Ética e Decoro Parlamentar. São nesses órgãos que parte importante dos processos político-disciplinares se realiza. De fato, no que concerne ao processo de cassação de mandato por quebra de decoro, este se desenvolve em dois momentos distintos e complementares. O primeiro se dá no âmbito dos Conselhos de Ética e Decoro Parlamentar, os quais apuram, apreciam e propõem a punição política. Em um segundo momento, há a deliberação do plenário da Câmara ou do Senado sobre a decretação da perda do mandato. A seguir, analisaremos as regras que regem os Conselhos, bem como os procedimentos disciplinares de sua competência.

302 BIM, Eduardo Fortunato. A cassação de mandato por quebra de decoro parlamentar. Sindicabilidade jurisdicional e tipicidade. Brasília: Revista de Informação Legislativa, v. 43, n. 169, jan./mar. 2006, p. 84. 


\subsubsection{Do Conselho de Ética e Decoro Parlamentar da Câmara dos Deputados}

\subsubsection{Competência}

O Regimento Interno da Câmara dos Deputados, a partir das alterações trazidas pela Resolução n. 02/2011, determina explicitamente em seu art. 21-E que o Conselho de Ética e Decoro Parlamentar é o órgão da Câmara dos Deputados competente para examinar as condutas puníveis e propor as penalidades aplicáveis aos deputados submetidos ao processo disciplinar previsto no Código de Ética e Decoro Parlamentar, sendo composto de 21 membros titulares e igual número de suplentes. Atentemos, então, ao fato de que o Conselho de Ética da Câmara não aplica qualquer tipo de punição, tão somente apura eventuais problemas disciplinares e propõe, conforme o caso e sua livre convicção, que seja ou não aplicada determinada pena prevista no Código de Ética e Decoro Parlamentar. Assim, antes que o plenário da Câmara aprecie a conduta parlamentar e decida sobre a perda do mandato, conforme procedimento previsto no art. $55, \S 2^{\circ}$, da Constituição, é necessária a apreciação por parte do Conselho de Ética e uma indicação de punição.

$\mathrm{O}$ art. $6^{\circ}$ do Código de Ética da Câmara especifica quatro competências para o Conselho de Ética e Decoro Parlamentar, quais sejam:

\footnotetext{
I - zelar pela observância dos preceitos deste Código, atuando no sentido da preservação da dignidade do mandato parlamentar na Câmara dos Deputados;

II - processar os acusados nos casos e termos previstos no art. 13;

III - instaurar o processo disciplinar e proceder a todos os atos necessários à sua instrução, nos casos e termos do art. 14;

IV - responder às consultas formuladas pela Mesa, Comissões, Partidos Políticos ou Deputados sobre matérias relacionadas ao processo político-disciplinar. [Grifo nosso.]
}

No bojo de nosso estudo, interessa destacar a competência para instaurar o processo disciplinar e dar prosseguimento a todos os atos necessários à sua instrução nos casos em que a penalidade a ser aplicada seja a suspensão do exercício do mandato ou a sua perda (art. 14 do Código de Ética). Nesse ponto, devemos lembrar que o Código de Ética da Câmara prevê outras penalidades, além da perda de mandato, como a censura verbal ou a escrita e a 
suspensão de prerrogativas regimentais (art. 10 do Código de Ética). Em todos os casos, como determinado pelo Regimento Interno, a competência para a instauração e a instrução do processo é do Conselho de Ética, não podendo qualquer outro órgão interno da Câmara usurpar essa competência.

\subsubsection{Composição}

Como já observamos, o Conselho de Ética é composto por 21 (vinte e um) membros titulares, com igual número de suplentes, os quais são designados para um mandato de dois anos. Se ao final desse período não tomarem posse novos integrantes, fica estendido o mandato até que tal fato ocorra, salvo na última sessão legislativa da Legislatura, cujo encerramento faz cessar o próprio mandato representativo popular, impedindo a continuidade dos trabalhos do Conselho (art. 21-E, $\S 1^{\circ}$, do RICD e art. $7^{\circ}$ do Código de Ética). O método adotado para a formação da composição do Conselho é igual ao utilizado na distribuição de vagas nas Comissões Permanentes da Câmara (art. 21-E, § $1^{\circ}$, do RICD), isto é, as cadeiras do Conselho são distribuídas pela Mesa a partir de um critério de proporcionalidade partidária ${ }^{303}$

${ }^{303}$ As regras definidoras da proporcionalidade numérica de cadeiras no Conselho de Ética e nas Comissões são assim previstas no RICD: “Art. 27 A representação numérica das bancadas em cada Comissão será estabelecida com a divisão do número de membros do Partido ou Bloco Parlamentar, aferido na forma do $\S 4^{\circ}$ do art. $8^{\circ}$ deste Regimento, pelo quociente resultante da divisão do número de membros da Câmara pelo número de membros da Comissão; o inteiro do quociente assim obtido, denominado quociente partidário, representará o número de lugares a que o Partido ou Bloco Parlamentar poderá concorrer na Comissão.

$\S 1^{\circ}$ As vagas que sobrarem, uma vez aplicado o critério do caput, serão destinadas aos Partidos ou Blocos Parlamentares, levando-se em conta as frações do quociente partidário, da maior para a menor.

$\S 2^{\circ}$ Se verificado, após aplicados os critérios do caput e do parágrafo anterior, que há Partido ou Bloco Parlamentar sem lugares suficientes nas Comissões para a sua bancada, ou Deputado sem legenda partidária, observar-se-á o seguinte:

I - a Mesa dará quarenta e oito horas ao Partido ou Bloco Parlamentar nessa condição para que declare sua opção por obter lugar em Comissão em que não esteja ainda representado;

II - havendo coincidência de opções terá preferência o Partido ou Bloco Parlamentar de maior quociente partidário, conforme os critérios do caput e do parágrafo antecedente;

III - a vaga indicada será preenchida em primeiro lugar;

IV - só poderá haver o preenchimento de segunda vaga decorrente de opção, na mesma Comissão, quando em todas as outras já tiver sido preenchida uma primeira vaga, em idênticas condições;

V - atendidas as opções do Partido ou Bloco Parlamentar, serão recebidas as dos Deputados sem legenda partidária;

VI - quando mais de um Deputado optante escolher a mesma Comissão, terá preferência o mais idoso, dentre os de maior número de legislaturas.

$\S 3^{\circ}$ Após o cumprimento do prescrito no parágrafo anterior, proceder-se-á à distribuição das demais vagas entre as bancadas com direito a se fazer representar na Comissão, de acordo com o estabelecido no caput, 
entre os Partidos e Blocos Parlamentares, assegurada a representação, sempre que possível, de todos os partidos políticos em funcionamento na Câmara dos Deputados (art. 58, $\S 1^{\circ}$, da Constituição Federal; arts. 23 e 26, caput, do RICD e art. $7^{\circ}$, § $3^{\circ}$, do Código de Ética). Em todo caso, deve ser mantida a composição inicial durante toda a legislatura, o que significa que, se houver alterações numéricas partidárias nas cadeiras parlamentares no decorrer da legislatura, isso não afetará a composição do Conselho. Nesse sentido, o Regimento Interno da Câmara traz a seguinte determinação:

Art. $26[\ldots] \S 4^{\circ}$ As alterações numéricas que venham a ocorrer nas bancadas dos Partidos ou Blocos Parlamentares decorrentes de mudanças de filiação partidária não importarão em modificação na composição das Comissões, cujo número de vagas de cada representação partidária será fixado pelo resultado final obtido nas eleições e permanecerá inalterado durante toda a legislatura.

A representação numérica de cada partido e bloco parlamentar no Conselho de Ética, assim como nas Comissões, é definida na primeira sessão legislativa de cada legislatura. Logo após, os líderes têm o prazo de cinco sessões para comunicar à Presidência os nomes dos indicados para compor o Conselho (art. 28, caput, do RICD). No início de cada sessão legislativa subsequente em que ocorrer o término do período de mandato, os líderes, dentro do mesmo prazo ora referido, devem indicar novamente os deputados que integrarão o Conselho, representando cada partido ou bloco parlamentar (art. $7^{\circ}, \S 4^{\circ}$, do Código de Ética).

Não podemos esquecer que o Corregedor da Câmara dos Deputados tem a faculdade de participar de todas as fases dos processos disciplinares instaurados no âmbito do Conselho de Ética, inclusive com direito de intervir nas discussões; todavia, não terá direito de voto em suas deliberações (art. $9^{\circ}, \S 4^{\circ}$, do Código).

Devemos observar que o Código de Ética prevê hipóteses em que o deputado fica impedido de integrar o Conselho de Ética. Essas vedações visam claramente garantir a seriedade, imparcialidade e moralidade do Conselho em sua atuação; assim, nos termos do art. $7^{\circ}, \S 2^{\circ}$, do Código de Ética, não podem figurar como seu membro:

considerando-se para efeito de cálculo da proporcionalidade o número de membros da Comissão diminuído de tantas unidades quantas as vagas preenchidas por opção”. 
I - o deputado submetido a processo disciplinar em curso, por ato atentatório ou incompatível com o decoro parlamentar;

II - que tenha recebido, na legislatura, penalidade disciplinar de suspensão de prerrogativas regimentais ou de suspensão do exercício do mandato, da qual se tenha o competente registro nos anais ou arquivos da Casa;

III - que esteja no exercício do mandato na condição de suplente convocado em substituição ao titular;

IV - condenado em processo criminal por decisão de órgão jurisdicional colegiado, ainda que a sentença condenatória não tenha transitado em julgado.

Depois de empossados os membros do Conselho de Ética e Decoro Parlamentar da Câmara, estes deverão eleger um Presidente e dois Vice-Presidentes dentre seus titulares, vedada a reeleição para o mesmo cargo na eleição subsequente (ar. 21-E, $\S 1^{\circ}$, do RICD e art. $7^{\circ}$ do Código de Ética) e também proibida a eleição de membro suplente e do Corregedor para o cargo de Presidente, consoante disposição do art $2^{\circ}, \S 1^{\circ}$, do Regulamento do Conselho. ${ }^{304}$ Uma vez composto o Conselho, seus membros só perdem o direito ao exercício do mandato em seu âmbito em caso de renúncia, falecimento ou perda do mandato no colegiado - é esta a regra disposta no art. $7^{\circ}, \S 1^{\circ}$, do Código de Ética, que, além disso, veda a aplicação para os membros do Conselho o disposto nos arts. 23 e 232 do Regimento Interno da Câmara, impedindo, assim, o seu afastamento mesmo em caso de mudança de bancada partidária. ${ }^{305}$

A perda do mandato no colegiado ocorre nos casos em que o membro titular deixar de comparecer a 5 (cinco) reuniões consecutivas ou, intercaladamente, a 1/3 (um terço) das reuniões durante a sessão legislativa, salvo motivo de força maior justificado por escrito ao Presidente do Conselho, a quem caberá declarar a perda do mandato (art. $7^{\circ}, \S 6^{\circ}$, do Código de Ética).

${ }^{304}$ O Regulamento dispõe sobre o funcionamento e a organização dos trabalhos do Conselho de Ética e Decoro Parlamentar da Câmara dos Deputados.

305 Dita os referidos artigos do RICD: “Art. 23 Na constituição das Comissões assegurar-se-á, tanto quanto possível, a representação proporcional dos Partidos e dos Blocos Parlamentares que participem da Casa, incluindo-se sempre um membro da Minoria, ainda que pela proporcionalidade não lhe caiba lugar.

Parágrafo único. O Deputado que se desvincular de sua bancada perde automaticamente o direito à vaga que ocupava em razão dela, ainda que exerça cargo de natureza eletiva. [...]

Art. 232 O Deputado que se desvincular de sua bancada perde, para efeitos regimentais, o direito a cargos ou funções que ocupar em razão dela". 
Vale, por fim, destacar que, se um membro do Conselho de Ética, durante o exercício de seu mandato, tiver contra si instaurado um processo disciplinar instruído com prova inequívoca da acusação, tal fato constituirá causa para o seu imediato afastamento de ofício, a ser determinada pelo Presidente do Conselho, devendo perdurar até a decisão final sobre o caso (art. $7^{\circ}, \S 7^{\circ}$, do Código de Ética).

\subsubsection{Instauração do processo ético-disciplinar}

De início, cabe uma ressalva de caráter geral: um processo político-disciplinar instaurado no âmbito do Conselho de Ética e Decoro Parlamentar, tanto da Câmara quanto do Senado, pode levar a muitos resultados, principalmente considerando as diversas penalidades aplicáveis a cada caso concreto de violação regimental, como já observamos. Nesse sentido, importa focarmos nosso estudo nas normas procedimentais que tenham relação direta ou indireta com a decretação de perda de mandato prevista no art. 55, II, da Constituição ressalte-se que o que fugir do escopo proposto não será objeto de nossa de análise.

Já vimos que, conforme o art. 55, § 2º da Constituição de 1988, o plenário da Câmara só decide sobre a perda do mandato de seu membro por quebra de decoro se houver provocação por parte da Mesa ou de partido político com representação no Congresso Nacional. Nesse ponto, importa elucidar que o poder de provocar o processo não se confunde com a sua efetiva instauração. Provocar significa o ato de apreciar determinada situação envolvendo parlamentar e, então, decidir que este deve ser investigado por meio de um processo no âmbito do Conselho de Ética. Por óbvio, essa apreciação inicial pode envolver instauração de procedimentos internos; contudo, não configura ainda, em um sentido estrito, a instauração do processo que possa levar à cassação do mandato.

Visando clarear nosso horizonte analítico, vale imaginarmos a seguinte hipótese: certo membro da Câmara dos Deputados comete ato inequivocamente ofensivo à dignidade institucional do Poder Legislativo e tal fato é amplamente divulgado pela imprensa e demais meios midiáticos. Se um partido político com representação no Congresso Nacional quiser ver o caso apreciado pelo Plenário em processo de cassação, como deve proceder? Nesse contexto, o partido político deverá representar, em termos formais, o deputado indecoroso 
diretamente junto à Mesa da Câmara, e não diretamente no Conselho de Ética - é essa a disposição do Código de Ética em seu art. 9: "as representações relacionadas com o decoro parlamentar deverão ser feitas diretamente à Mesa da Câmara dos Deputados". Outra pergunta se torna inevitável: se a Constituição atribuiu competência para provocar o processo de cassação tanto à Mesa quanto ao partido político, não haveria uma ofensa a essa determinação Constitucional quando se impõe que a representação do partido seja apresentada diretamente à Mesa da Câmara dos Deputados? Na verdade, o oferecimento da representação na Mesa da Câmara é apenas uma regra de formalidade, pois quando o referido órgão recebe a representação subscrita por partido político - nos termos do art. $55, \S 2^{\circ}$, da Constituição não toma para si a apreciação se deve ou não provocar a instauração do processo; pelo contrário, está obrigado, no prazo de 3 (três) sessões ordinárias, a remeter a representação diretamente para o Conselho de Ética e Decoro Parlamentar, consoante o art. $9^{\circ}$, $\S 3^{\circ}$, do Código de Ética.

Um olhar desatento a tais circunstâncias dará a aparência de que a Mesa é a única que poderia provocar a instauração do processo de cassação de mandato por quebra de decoro no âmbito do Conselho de Ética da Câmara. Aliás, ao lermos o art. $2^{\circ}$ do Regulamento do Conselho de Ética, verificaremos a seguinte redação: "O Conselho de Ética e Decoro Parlamentar atuará mediante provocação da Mesa da Câmara dos Deputados, nos casos de instauração de processo disciplinar". Ora, a impressão que passa esse artigo é a de que somente a Mesa da Câmara pode provocar a instauração do processo com vistas à futura apreciação do plenário nos termos do art. $55, \S 2^{\circ}$, da Constituição, o que não se revela, conforme se viu, juridicamente verdadeiro.

Passemos agora a outra ordem de considerações sobre a mesma situação colocada anteriormente. Pensemos em uma circunstância na qual nem o partido político com representação no Congresso Nacional, nem a própria Mesa da Câmara atue no sentido de se representar determinado deputado por quebra de decoro - nesse caso, há alguma garantia de que algo possa ser feito? De fato, a Mesa da Câmara pode ser acionada por qualquer cidadão por meio de requerimento a provocar a instauração do processo de cassação de mandato, é essa a conclusão que temos a partir do $\S 1^{\circ}$ do art. $9^{\circ}$ do Código de Ética, o qual dispõe que "qualquer cidadão é parte legítima para requerer em face de deputado que tenha incorrido em conduta incompatível ou atentatória ao decoro parlamentar, especificando os fatos e as 
respectivas provas". Observe-se, então, que o cidadão não representa em face de deputado que tenha cometido violação às regras éticas institucionais, mas apenas requer que a Mesa da Câmara elabore essa representação; por isso, ao receber tal requerimento, a Mesa apenas instaura um procedimento de caráter interno com o intuito de apreciá-lo. Ao final, se a Mesa concluir que há no requerimento indícios suficientes da acusação sem qualquer impedimento jurídico, provoca-se a instauração do processo político-disciplinar no Conselho de Ética por meio de representação.

Conclui-se do exposto que à Mesa da Câmara dos Deputados compete sempre encaminhar ao Conselho de Ética as representações feitas diante de conduta ofensiva ao decoro de seus membros, seja exercitando competência própria de provocar os processos, seja apenas encaminhando diretamente a representação feita por partido político.

O Conselho de Ética da Câmara, ao receber a representação encaminhada pela Mesa, instaurará imediatamente o processo político-disciplinar, determinando o registro e a autuação da representação (art. $7^{\circ}$ do Regulamento). A partir da instauração do processo não poderá mais ser retirada a representação, nem mesmo pela parte que a propôs (art. $14, \S 5^{\circ}$, do Código de Ética). Destarte, a desistência da representação por parte de quem a propôs não gera a extinção do processo, basta ver que não se trata da defesa do interesse do representante, mas de interesse público; assim, os parlamentares estão autorizados a apreciar a possível ocorrência de ofensa ao decoro, bem como decidir sobre a cassação do mandato ainda que após a desistência da representação. Esse parece ser o melhor entendimento, e nessa trilha é que temos a posição do Ministro do Supremo Tribunal Federal, Cezar Peluso:

Trata-se de procedimento que, analogamente, ao que sucede com a ação penal, a ação de inconstitucionalidade e a ação popular, escapa ao campo de disposição dos legitimados, porque concerne a interesse público e, no caso, especificamente, ao interesse público do Parlamento, uma vez que está em jogo, na suposição ou na imputação de quebra de decoro parlamentar, a integridade ética do Parlamento, a qual diz respeito a interesse evidentemente público. De modo que seria impossível que, com a desistência da representação, pudesse ser interrompido o procedimento que se desencadeou. (Supremo Tribunal Federal, MS 25.647, Rel. Min. Cezar Peluso, DJ de 15.12.2006.) 
No que se refere ao tempo de duração dos processos político-disciplinares que visem à decretação da perda de mandato por quebra de decoro, o Código de Ética prevê um prazolimite para a apreciação em Plenário da Câmara, que é de 90 (noventa) dias, contados a partir de sua instauração no Conselho de Ética (art. 16, $§ 1^{\circ}$, do Código de Ética). Na hipótese de não cumprimento do prazo, o Código estabelece alguns efeitos dependendo de onde o processo se encontre. Dessa maneira, se o processo estiver no Conselho de Ética, depois de concluída a fase instrutória, ele passa imediatamente a sobrestar a pauta do Conselho. Se estiver em grau de recurso na Comissão de Constituição e Justiça, passa a sobrestar a pauta da Comissão (art. 16, § $3^{\circ}$, I e II, do Código de Ética).

Logo depois da instauração do processo, o Presidente do Conselho designará o deputado relator (art. 14, $\S 4^{\circ}$, I, do Código de Ética), que deverá ser escolhido a partir de uma lista composta pelo nome de 3 (três) membros do Conselho, formada mediante sorteio. Além disso, a fim de garantir a imparcialidade do relator, nessa lista não poderão constar nomes de deputados do mesmo partido ou bloco parlamentar do representado nem poderão pertencer ao mesmo Estado deste (art. 13, I, $a$ e $b$, do Código de Ética). No mesmo sentido, caso a representação tenha sido elaborada por partido político, nenhum de seus membros poderá também compor a lista (art. 13, I, c, do Código de Ética). A partir dos nomes integrantes da lista, o presidente do Conselho indicará o relator do processo (art. $7^{\circ}, \S 2^{\circ}$, do Regulamento). Caso o relator posteriormente desista da relatoria ou por algum motivo fique impedido de exercê-la, o presidente do Conselho designará relator substituto (art. $7^{\mathbf{o}}, \S 3^{\mathbf{o}}$, do Regulamento).

Nesse momento inicial do processo, o relator poderá se manifestar pela inépcia ou falta de justa causa da representação, submetendo tal entendimento ao Plenário do Conselho (art. 14, $\S 4^{\circ}$, I, do Código de Ética), mas só o poderá fazer nos casos em que o processo tenha sido provocado por representação de partido político. Se o Conselho de Ética acolher o posicionamento do relator, o pronunciamento terá natureza terminativa, salvo se houver recurso ao Plenário da Casa subscrito por 1/10 (um décimo) de seus membros, observado o art. 58 do Regimento Interno da Câmara dos Deputados (art. 14, § $4^{\circ}$, III, do Código de Ética).

Não ocorrendo a hipótese de inépcia ou ausência de justa causa, uma cópia da representação será encaminhada ao parlamentar acusado (art. 14, § 4º II, do Código). 


\subsubsection{Da defesa do representado}

Não há que se discutir que, nos processos ético-disciplinares instaurados na esfera do Conselho de Ética e Decoro Parlamentar da Câmara dos Deputados (e também do Senado Federal), deve ser assegurado ao representado o direito de ampla defesa e do contraditório, consoante teor do art. $5^{\circ}, \mathrm{LV}$, da Constituição Federal. Por tal razão, o representado deverá ser intimado de todos os atos praticados pelo Conselho e poderá se manifestar em todas as fases do processo (art. 10, § 5 , do Código de Ética).

Após a devida instauração do processo e da notificação do acusado, este terá o prazo de 10 (dez) dias úteis para apresentar sua defesa escrita, indicar provas e arrolar testemunhas, em número máximo de 8 (oito) (art. 14, $\$ 4^{\circ}$, II, do Código de Ética). Embora o Código de Ética da Câmara não estabeleça regra específica sobre a forma de como a intimação deve ocorrer, temos que esta deve ser feita preferencialmente de forma pessoal, podendo também ser realizada por intermédio do gabinete do representado. Transcorrido o prazo referido sem apresentação da defesa pelo representado, o presidente do Conselho deverá nomear defensor dativo para, em prazo idêntico, oferecer ou requerer a produção probatória, ressalvado o direito do representado de, a todo tempo, nomear outro de sua confiança ou a si mesmo defender-se. ${ }^{306}$ É facultado ao acusado, em todas as fases do processo, inclusive em Plenário da Câmara dos Deputados, constituir advogado para sua defesa ou fazê-la pessoalmente ou por intermédio do parlamentar que indicar, desde que não integrante do Conselho de Ética (art. 15 do Código de Ética).

\subsubsection{Da instrução probatória}

Nos casos que envolvam a aplicação da penalidade de perda de mandato, assim que a defesa do acusado é apresentada o relator procederá às diligências e à instrução probatória que entender necessárias no prazo improrrogável de 40 (quarenta) dias úteis (art. 14, § $4^{\circ}, \mathrm{IV}$, do Código de Ética). Quando o Código de Ética indica que o relator irá proceder “às diligências e

\footnotetext{
${ }^{306}$ Esta é a determinação do art. $9^{\circ}$ do Regulamento Interno do Conselho de Ética. Importante notar, entretanto, que o citado artigo está parcialmente em conflito com o Código de Ética, tendo em vista que prevê prazo de 5 (cinco) sessões para que o representado apresente defesa, enquanto, como vimos, o Código estabelece o prazo de 10 (dez) dias úteis. Tem-se, então, que vale o especificado no Código.
} 
à instrução probatória que entender necessárias", significa que ele pode e deve atuar no sentido de colher os elementos probatórios para a formação de convicção quanto ao caso, descartando o que não for pertinente ou desnecessário em razão deste fim. Com efeito, se o deputado acusado requerer a produção de provas que não possam agregar qualquer conhecimento novo com respeito ao caso, o relator poderá indeferir este pedido. Da mesma forma deverá atuar em caso de requerimento de diligências impertinentes que não guardem qualquer relação com a situação analisada na representação e tenham um caráter claramente procrastinatório. Não há quanto a esta circunstância violação do princípio da ampla defesa ou do contraditório.

Nesse contexto, há um aspecto relevante a ser ressaltado: os Conselhos de Ética e Decoro Parlamentares de ambas as Casas legislativas - Câmara e Senado - não gozam dos poderes de investigação próprios das autoridades judiciais, como ocorre no âmbito das Comissões Parlamentares de Inquérito por determinação do art. 58, $\S 3^{\circ}$ da Constituição Federal. Com efeito, os Conselhos de Ética e Decoro Parlamentares não têm o poder de compelir a presença de testemunha arrolada pelo representado, no máximo a convida para depor, sendo de responsabilidade do representado o seu encaminhamento em dia e horário marcado. Obviamente tal situação fragiliza a atuação dos Conselhos, mas até que surja alteração normativa constitucional sobre o tema, nada pode ser feito.

Ressalte-se que durante a fase de instrução a defesa deve sempre estar apta a elaborar suas alegações e produzir suas provas por último, resguardando sempre possibilidade do acusado pessoalmente ou por intermédio de seu defensor constituído, se manifestar sobre todos os elementos probatórios colhidos durante a instrução, rebatendo por todos os meios as alegações acusatórias. Ofende ao princípio constitucional do contraditório, da ampla defesa e do devido processo legal a inversão procedimental durante a instrução probatória que deixe a acusação firmar seu entendimento por último. Nesse sentido temos o posicionamento o Supremo Tribunal Federal em julgado cuja ementa transcrevemos:

Parlamentar. Perda de mandato. Processo de cassação. Quebra de decoro parlamentar. Inversão da ordem das provas. Reinquirição de testemunha de acusação ouvida após as da defesa. Indeferimento pelo Conselho de Ética. Inadmissibilidade. Prejuízo presumido. Nulidade consequente. Inobservância do contraditório e da ampla defesa. Vulneração do justo processo da lei (due process of law). Ofensa ao art. $5^{\circ}$, LIV e LV, e art. 55, § $2^{\circ}$, da CF. Liminar 
concedida em parte, pelo voto intermediário, para suprimir, do Relatório da Comissão, o inteiro teor do depoimento e das referências que lhe faça. Votos vencidos. Em processo parlamentar de perda de mandato, não se admite aproveitamento de prova acusatória produzida após as provas de defesa, sem oportunidade de contradição real. (Supremo Tribunal Federal, MS 25.647-MC, Rel. Min. Cezar Peluso, DJ de 15.12.2006.) [Grifo nosso.]

No período que vai da instauração do processo até o encerramento da instrução a Mesa da Câmara, o representante, o representado ou qualquer membro da Casa poderá requerer juntada de documentos (art. 13 do Regulamento).

Vale lembrar que, conforme a Questão de Ordem no Inquérito n. 2.725, instaurado no âmbito do Supremo Tribunal Federal, o Ministro Carlos Britto entendeu possível o envio de informações sigilosas, obtidas a partir de autorização judicial, ao Conselho de Ética, visando instruir processo ético-disciplinar. Eis a ementa da citada decisão:

Ementa: Questão de ordem. Inquérito policial. Supervisão do Supremo Tribunal Federal. Pedido veiculado pelo Conselho de Ética e Decoro Parlamentar da Câmara dos Deputados: Compartilhamento das informações. Finalidade: Apurações de cunho disciplinar. Presença de dados obtidos mediante interceptação telefônica, judicialmente autorizada. Prova emprestada. Admissibilidade. Juízo de proporcionalidade (Inciso XII do art. $5^{\circ}$ e $\S 2^{\circ}$ do art. 55 da CF/88). Precedentes. 1. A medida pleiteada pelo Conselho de Ética e Decoro Parlamentar da Câmara dos Deputados se mostra adequada, necessária e proporcional ao cumprimento dos objetivos do parágrafo $2^{\circ}$ do artigo 55 da Constituição Federal de 1988. 2. Possibilidade de compartilhamento dos dados obtidos mediante interceptação telefônica, judicialmente autorizada, para o fim de subsidiar apurações de cunho disciplinar. Precedente específico: Segunda Questão de Ordem no Inquérito 2.424 (Ministro Cezar Peluso). 3. Questão de Ordem que se resolve no sentido do deferimento da remessa de cópia integral dos autos ao Sr. Presidente do Conselho de Ética e Decoro Parlamentar da Câmara dos Deputados, a quem incumbirá a responsabilidade pela manutenção da cláusula do sigilo de que se revestem as informações fornecidas (Supremo Tribunal Federal, Inq. 2725 QO/SP - Rel. Min. Carlos Britto, DJ de 25.09.2008.)

As diligências a serem realizadas fora do Distrito Federal dependerão de autorização prévia do Presidente do Conselho (art. 11, § $2^{\circ}$, do Regulamento). Ao final da instrução, o relator poderá concluir pela procedência total ou parcial da representação ou pela sua improcedência, devendo oferecer, nas 2 (duas) primeiras hipóteses, projeto de resolução 
destinado à declaração da perda de mandato ou, ainda, propor a requalificação da conduta punível e da penalidade cabível, com o encaminhamento do processo à autoridade ou órgão competente (art. 14, $\S 4^{\circ}$, IV, do Código de Ética). Considerando improcedente a representação, o relator deverá indicar o seu arquivamento.

Finalizado o parecer, este será recebido pela Secretaria do Conselho, que o desdobrará em duas partes: relatório e voto. De imediato, o relatório será disponibilizado para divulgação, mantendo-se em sigilo o voto até a sua leitura em reunião pública marcada para apreciação do parecer (art. 17, § $2^{\circ}$, do Regulamento).

\subsubsection{Da apreciação do parecer}

No início da reunião pública marcada para apreciação do parecer pelos membros do Conselho, anunciada a matéria pelo presidente, o relator procederá à leitura do relatório, isto é, da primeira parte do parecer (art. 18, I, do Regulamento). A seguir, o representado ou seu procurador terão prazo de 20 (vinte) minutos, prorrogáveis por mais 10 (dez), para apresentar defesa (art. 18, II, do Regulamento). Após a apresentação da defesa, o relator fará a leitura do seu voto (art. 18, III, do Regulamento), abrindo-se, em seguida, a discussão sobre o parecer (art. 14, § $4^{\circ}$, do Código de Ética), em que cada membro do Conselho poderá usar a palavra por 10 (dez) minutos improrrogáveis. Os deputados que não integrem o Conselho de Ética, mas queiram participar das discussões, terão o prazo de 5 (cinco) minutos para uso da palavra, sendo facultada a apresentação de requerimento de encerramento de discussão após falarem quinze deputados (art. 17, IV, do Regulamento).

A deliberação sobre o parecer pelo Conselho se dá por meio de votação nominal que decide quanto à sua aprovação ou rejeição, sendo considerada posição vencedora aquela que conseguir maioria absoluta de votos (art. 14, § $4^{\circ}$, VI c/c art. 18, VIII, do Regulamento). Em caso de um membro do Conselho pedir vista do processo, ser-lhe-á concedida por duas sessões, e se mais de um membro, simultaneamente, pedir vista, ela será conjunta (art. 18, VI, do Regulamento). 
O presidente do Conselho tem a faculdade de abrir prazo de 10 (dez) minutos improrrogáveis para réplica do relator, concedendo obrigatoriamente idêntico prazo para apresentação de tréplica pelo representado ou seu procurador (art. 18, VII, do Regulamento).

$\mathrm{Na}$ apreciação do parecer, que, conforme vimos, pode ser pela procedência total ou parcial da representação ou por sua improcedência, os membros do Conselho deverão levar em conta quando da escolha da sanção a ser aplicada, a gravidade da infração cometida, os danos que dela provierem para a Câmara dos Deputados e para o Congresso Nacional, as circunstâncias agravantes ou atenuantes e os antecedentes do infrator (art. 10, § $1^{\circ}$, do Código de Ética). Destarte, a decisão tomada pelo Conselho deve ser razoável e proporcional a cada caso submetido à sua apreciação. Nessa medida, o Conselho poderá, se considerar procedente determinada representação, reenquadrar o pedido feito quanto à penalidade a ser aplicada, seja por indicar a aplicação de punição mais grave do que a feita na representação, seja por propor cominação mais leve (art. 10, $\S 1^{\text {o }}$, do Código de Ética).

Se o parecer original do relator for rejeitado pelo Conselho, será obrigatória a designação de um novo relator, dando-se preferência para aqueles que, durante a discussão da matéria, tenham se manifestado contrariamente à posição do primeiro (art. 14, § $4^{\circ}, \mathrm{V}$, do Código de Ética). Essa medida tem o objetivo de garantir que um parecer, de acordo com o posicionamento da maioria do Conselho, seja aprovado. Assim, se um parecer pela improcedência da representação é rejeitado, isto é, se os membros do Conselho são pela procedência da representação, será necessária a elaboração de um parecer nesse sentido, em que um novo relator designado pelo presidente deverá elaborá-lo no prazo de 2 (duas) sessões (art. 18, XI, do Regulamento).

Se depois de concluído o processo ético-disciplinar, o representado sentir-se prejudicado por quaisquer atos emitidos pelo Conselho ou seus membros, por motivo de violação da norma constitucional ou regimental, incluindo regras do próprio Código, poderá este interpor recurso, no prazo de 5 (cinco) dias úteis, à Comissão de Constituição e Justiça e de Cidadania da Câmara, que terá efeito suspensivo, hipótese na qual a comissão se pronunciará exclusivamente sobre os vícios apontados, observando, para tanto, o prazo de 5 (cinco) dias (art. 14, $\S 4^{\circ}$, VII, do Código de Ética). Finalizado o trâmite do processo, este é encaminhado à Mesa da Câmara e, uma vez lido no expediente, será publicado e distribuído 
em avulsos para inclusão, no prazo de duas sessões ordinárias, na pauta da Ordem do Dia ${ }^{307}$ (art. $14, \S 4^{\circ}$, VIII, e art. $16, \S 2^{\circ}$, do Código de Ética). Se o processo não for incluído na pauta dentro do prazo referido, ele deverá figurar como item preferencial na Ordem do Dia de todas as sessões deliberativas seguintes até que se ultime sua apreciação (art. 16, § $3^{\circ}$, III, do Código de Ética).

\subsubsection{Do Conselho de Ética e Decoro Parlamentar do Senado Federal}

Dita o art. 22 do Código de Ética do Senado Federal: "Compete ao Conselho de Ética e Decoro Parlamentar zelar pela observância dos preceitos deste Código e do Regimento Interno, atuando no sentido da preservação da dignidade do mandato parlamentar no Senado Federal". Trata-se mais de uma determinação de princípios do que de definição de competência funcional precisa. Ao contrário do que ocorre na Câmara dos Deputados, não há um artigo definindo especificamente a competência do Conselho de Ética do Senado para examinar as condutas e propor as penalidades aplicáveis aos Senadores, mas, em todo caso, é possível extrair do texto do Código de Ética essa competência.

Impende, entretanto, constatarmos inicialmente que o Conselho de Ética e Decoro Parlamentar do Senado tem o poder de aplicar penalidades aos senadores em processos político-disciplinares, por exemplo, no caso da penalidade de advertência (art. $8^{\circ}$ do Código de Ética) e de censura verbal e escrita (art. $9^{\circ}, \S 1^{\circ}$ e $\S 2^{\circ}$, do Código de Ética). Vimos que, no âmbito da Câmara dos Deputados, o Conselho de Ética tem apenas competência para iniciar o processo ético-disciplinar e tomar todas as medidas referentes à sua instrução, podendo, ao final, propor a aplicação de uma penalidade sem, contudo, decidir efetivamente pela punição.

${ }^{307}$ Dispõe o RICD: “Art. 66. As sessões ordinárias terão duração de cinco horas, iniciando-se às nove horas, quando convocadas para as sextas-feiras, e, nos demais dias da semana, às quatorze horas, e constarão de:

I - Pequeno Expediente, com duração de sessenta minutos improrrogáveis, destinado à matéria do expediente $\mathrm{e}$ aos oradores inscritos que tenham comunicação a fazer;

II - Grande Expediente, a iniciar-se às dez ou às quinze horas, conforme o caso, com duração improrrogável de cinquenta minutos, distribuída entre os oradores inscritos;

III - Ordem do Dia, a iniciar-se às onze ou dezesseis horas, conforme o caso, com duração de três horas prorrogáveis, para apreciação da pauta;

IV - Comunicações Parlamentares, desde que haja tempo, destinadas a representantes de Partidos e Blocos Parlamentares, alternadamente, indicados pelos Líderes". 
Já no que diz respeito ao processo político-disciplinar que possa levar à perda de mandato nos termos do art. 55, II, $\S 2^{\circ}$, da Constituição, é o Conselho de Ética do Senado que tem competência para instaurar o processo e instruí-lo, consoante o estabelecido no seu art. $15-\mathrm{A}, \S 1^{\circ}$, cujo teor diz que "se houver indícios de prática de ato que possa sujeitar o Senador à perda do mandato, em decisão adotada pelo Conselho de Ética e Decoro Parlamentar, que se dará em processo de votação nominal e aberta, a representação será recebida e será instaurado o processo disciplinar". Aqui também haverá a manifestação dos membros do Conselho antes do pronunciamento do Plenário.

\subsubsection{Composição}

O Conselho de Ética do Senado é composto por 15 membros titulares, com igual número de suplentes, eleitos para mandato de 2 (dois) anos, devendo ser observado, quanto à distribuição das vagas e dentro das possibilidades, o princípio da proporcionalidade partidária e o rodízio entre os partidos políticos ou blocos parlamentares não representados (art. 23 do Código de Ética). A confirmação dos nomes dos senadores titulares de um mandato dentro do Conselho se dá por indicação dos líderes partidários apresentada à Mesa (art. 23, § $1^{\circ}$, do Código de Ética). Importante notar que, toda vez que houver indicação formal para um senador ocupar vaga do Conselho de Ética, esta deverá estar acompanhada de declarações atualizadas referentes a seus bens, fontes de renda, atividades econômicas e profissionais, nos termos dos incisos I, II, III do art. $6^{\circ}$ do Código, que prevê as declarações públicas obrigatórias (art. $23, \S 2^{\circ}$ ). Ademais, é preciso que, com a indicação do senador para compor o Conselho, seja juntada declaração assinada pelo Presidente da Mesa, certificando a inexistência de quaisquer registros nos arquivos e anais do Senado referentes à prática de atos ou irregularidades capitulados nos arts. $8^{\circ}$ e 11 do Código, independentemente da legislatura ou sessão legislativa em que tenham ocorrido (art. 23, $\S 4^{\circ}$ ).

Quanto à organização interna e a ordem de seus trabalhos, o Conselho de Ética do Senado observará as disposições regimentais relativas ao funcionamento das Comissões, inclusive no que diz respeito à eleição de seu presidente e designação de relatores (art. 24 do Código de Ética). O Código traz também hipótese de desligamento de membro que se dará 
automaticamente quando este, sem justificativa, não comparecer a três reuniões, consecutivas ou não, bem assim o que faltar, ainda que justificadamente, a mais de seis reuniões durante sessão legislativa (art. 24, § $2^{\circ}$, do Código de Ética). Poderá também ser desligado o membro que não guarde descrição e sigilo no exercício da função (art. $24, \S 1^{\circ}$, do Código de Ética).

Cabe salientar, por fim, que o Corregedor do Senado tem direito de participação nas deliberações do Conselho de Ética, com direito a voz e voto, ao contrário do que ocorre no Conselho da Câmara, em que o Corregedor tem direito a voz, mas não a voto.

\subsubsection{Da Instauração do processo a partir de representação}

Já vimos que a competência para provocar o processo de cassação de mandato por quebra de decoro, conforme teor do $\S 2^{\circ}$ do art. 55 da Constituição pertence à Mesa da Casa legislativa a que pertencer o parlamentar faltoso e ao partido político com representação no Congresso Nacional. Destarte, ambas as instâncias políticas institucionais têm o poder de representar contra parlamentar diante de condutas ofensivas à dignidade institucional do Poder Legislativo. Note-se que, no Senado Federal, a regra inserida no art. 14 do seu Código de Ética e Decoro Parlamentar é clara, ao determinar que a representação contra senador que tenha cometido faltas éticas deve ser ofertada diretamente ao Conselho de Ética. Nesse ponto, encontramos mais uma diferença em relação aos processos de mesma espécie instaurados na Câmara dos Deputados, na qual todas as representações são apresentadas à Mesa da Casa, inclusive as elaboradas por partidos políticos, embora, como analisamos, a Mesa não tenha o poder de apreciar sua pertinência, mas apenas encaminhe-as diretamente ao Conselho de Ética. Convém observar, todavia, que qualquer parlamentar, cidadão ou até mesmo pessoa jurídica poderá ofertar denúncia no Conselho de Ética e Decoro Parlamentar do Senado diante de conduta de senador violadora dos princípios éticos da instituição, e esta poderá dar ensejo à instauração de processo de cassação de mandato. Uma vez que o Código de Ética do Senado demarca contorno jurídico distinto quanto a essas formas de se dar início ao processo de cassação de mandato, importa fazermos tal separação em nosso estudo, começando nossa análise pela instauração a partir de representação, sem mediação de denúncia. 
5.2.2.2.1 Do exame preliminar de admissibilidade da representação

O art. 14 do Código de Ética do Senado traz requisitos para a oferta de representação na esfera do Conselho de Ética e Decoro Parlamentar; assim, sob pena de preclusão, deve constar na representação rol de testemunhas em número máximo de 5 (cinco), os documentos que a instruem e a especificação de demais provas que se pretende produzir.

Apresentada a representação, ao contrário do que ocorre na Câmara dos Deputados, não se instaura imediatamente o processo ético-disciplinar, mas inicia-se uma fase de exame preliminar, que é realizada pelo presidente do Conselho de Ética e Decoro Parlamentar. Com efeito, este tem o prazo de 5 (cinco) dias para analisar a admissibilidade ou não da representação (art. 14, $\S 1^{\circ}$, do Código de Ética). Nessa fase de exame preliminar de admissibilidade, o presidente do Conselho está, em algumas hipóteses, autorizado a determinar o arquivamento da representação. Assim pode proceder nos casos de falta de legitimidade do autor da representação, se não houver identificação do senador acusado e dos fatos que lhe são imputados ou, ainda, se os fatos relatados na representação forem referentes a período anterior ao mandato ou manifestamente improcedentes (art. 14, I, II, III, do Código de Ética). Vê-se que, nessa fase, deve acontecer a análise quanto aos requisitos para a abertura do processo que já estudamos. A partir da publicação da decisão pelo arquivamento da representação, cabe recurso no prazo de 2 (dois) dias úteis ao plenário do Conselho de Ética. Esse recurso deverá ser subscrito por, pelo menos, 5 (cinco) membros do Conselho (art. 14, $\S 2^{\circ}$, do Código de Ética).

Não havendo qualquer problema quanto à admissibilidade da representação, o presidente do Conselho de Ética determinará o seu registro e autuação, bem como designará um relator. A escolha do relator será feita no prazo de 3 (três) dias úteis, mediante sorteio entre os membros do Conselho, de preferência entre aqueles que não sejam membros do partido político do representado ou do representante (art. 15, III, do Código de Ética). 


\subsection{Da defesa prévia}

Em decorrência da admissibilidade da representação, o presidente do Conselho determinará também a expedição de notificação ao senador representado para que apresente sua defesa prévia no prazo de $10(\mathrm{dez})$ dias úteis. Essa notificação deverá, necessariamente, estar acompanhada de cópia da representação e demais documentos que a instruíram. O prazo para apresentação de defesa prévia será contado a partir da intimação pessoal do representado ou quando esta for recebida em seu gabinete no Senado Federal (art. 15, I e II, do Código de Ética). Sob pena de preclusão, conforme o caso, a defesa prévia deverá estar acompanhada dos documentos que se fizerem necessários para a defesa do representado e rol de testemunhas até o máximo de 5 (cinco) (art. 15, II, $a$, do Código de Ética).

Uma vez transcorrido o prazo para apresentação de defesa prévia, e não havendo manifestação do interessado, o presidente do Conselho de Ética nomeará defensor dativo, reabrindo o prazo para sua apresentação, ressalvado o direito do representado de, a qualquer tempo, nomear outro defensor de sua confiança ou defender-se por si mesmo, sem abertura de novo prazo (art. 15, II, $b$, do Código de Ética). Cabe lembrar que nenhum membro do Conselho poderá ser nomeado como defensor dativo (art. 14, $\S 1^{\circ}$, do Código de Ética).

Impende destacar que durante todo o trâmite procedimental no Conselho de Ética do Senado, pouco importando se pela formalidade do Código há ou não efetivamente processo instaurado, recebida a representação ou denúncia, o senador acusado passa a ter pleno direito ao exercício da ampla defesa e do contraditório, devendo receber intimação por meio de seu gabinete ou por intermédio de procurador, de todos os atos e termos do processo disciplinar. Aliás, é esta a determinação do art. 16 do Código de Ética. Isso fica mais evidente quando percebemos que, mesmo antes de o Código mencionar a instauração de processo, já determina a apresentação de "defesa prévia" por parte do senador. 


\subsection{Da instauração do processo}

Após a apresentação da defesa prévia, o relator terá prazo de 5 (cinco) dias úteis para apresentar relatório preliminar ao Conselho, que, por sua vez, em igual prazo, realizará análise inicial do mérito da representação, no qual examinará se há indícios de prática de ato que possa sujeitar o senador à perda do mandato ou à aplicação de outras penalidades previstas no Código de Ética (art. 15-A do Código de Ética). O relatório preliminar que indique a aplicação da penalidade de perda de mandato por quebra de decoro será submetido no Conselho à votação aberta e nominal, que decidirá sobre a procedência ou improcedência da representação (art. 15-A, $\S 1^{\circ}$, do Código de Ética).

Decidindo pela procedência da representação, isto é, que há indícios suficientes que podem levar o senador representado a perder o seu mandato, o Conselho receberá e instaurará efetivamente o processo de cassação de mandato por quebra de decoro (art. 15-A do Código de Ética). Segundo estabelecido pelo próprio Código de Ética do Senado, é a partir da publicação dessa decisão que se instaura o processo em que o parlamentar fica impedido de renunciar (art. 55, $\S 4^{\circ}$, da Constituição Federal). Ao longo de nosso estudo, tivemos oportunidade de constatar que a renúncia ao mandato atualmente, segundo a Lei Complementar n. 64/90, em seu art. $1^{\circ}$, I, $k$, alterada pela Lei Complementar n. 135/2010, gera para o parlamentar que tenha contra si qualquer denúncia encaminhada na respectiva Casa a que pertence a inelegibilidade. Assim, toda discussão quanto ao momento da aplicação da regra de suspensão da eficácia da renúncia perde um pouco do seu sentido, já que esta acontece, em regra, com o objetivo de fugir à responsabilidade perante os pares com o claro intuito de não ser atingido pela inelegibilidade. Mas devemos dizer que isso não invalida a regra da suspensão da eficácia do pedido de renúncia em caso de instauração de processo que possa levar à perda de mandato. Nesse ponto, importa concluir que a forma como o processo de cassação de mandato parlamentar foi desenhado no Código de Ética do Senado privilegia a renúncia em detrimento da responsabilização perante seus pares. Expliquemos: consoante analisamos, o Código de Ética do Senado prevê todo um encadeamento de atos antes de instaurar efetivamente o processo, ou seja, ao receber a representação, o Conselho de Ética não decreta a abertura imediata do processo, mas institui uma fase preliminar que efetivamente não impede a renúncia, o que nos parece algo completamente descabido. 
A efetiva instauração do processo de cassação autoriza o Conselho de Ética a manifestar-se sobre a necessidade de afastamento do representado do cargo que eventualmente exerça, de dirigente em Comissão ou na Mesa, desde que exista indício da prática de ato incompatível com o decoro e que haja receio de dano irreparável ou de difícil reparação à imagem do Senado Federal (art. 15-A, § 2º I e II, do Código de Ética).

Caso o Conselho de Ética, ao votar o relatório, decida que não há indícios de prática de ato que possa sujeitar o senador à perda de mandato, mas que há hipótese de aplicação de outras penalidades, por exemplo, advertência ou censura verbal, a representação será convertida em denúncia, instaurando-se processo disciplinar para aplicação das penalidades cabíveis (art. 15-A, $\S 5^{\circ}$, do Código de Ética). Verificamos, então, que há possibilidade de reenquadramento da conduta (gravidade), de modo a possibilitar a aplicação de outras penalidades que não a cassação de mandato.

Como terceira possibilidade decisória, o Conselho poderá optar pela improcedência da representação, arquivando-a.

5.2.2.3 Da instauração do processo a partir de denúncia

Como regra geral, o processo de cassação de mandato por ofensa ao decoro parlamentar é instaurado por provocação da Mesa da respectiva Casa congressual ou por partido político com representação no Congresso Nacional. O Código de Ética do Senado prevê, em todo caso, a hipótese em que qualquer parlamentar, cidadão ou pessoa jurídica pode diretamente oferecer denúncias relativas ao descumprimento, por senador, de preceitos contidos no Regimento Interno e no Código de Ética (art. 17 do Código de Ética). Uma vez ofertada ao Conselho de Ética, essas denúncias seguem tramitação específica, de modo que, ao final, podem subsidiar a apresentação de representação e instauração de processo políticodisciplinar de cassação de mandato. Importante notar que o próprio Conselho de Ética, independentemente de denúncia, poderá apurar eventuais faltas de senador, seguindo as mesmas regras regimentais como se uma denúncia tivesse lhe sido ofertada (art. 17, § 10, do Código de Ética). Como veremos, a denúncia apenas dá subsídio para a apresentação da representação por quem de direito competente para tal, isto é, a Mesa do Senado e o partido 
político com representação no Congresso Nacional. Essa é uma medida salutar no caso de tanto a Mesa quanto os partidos políticos ficarem inertes diante de conduta agressora da imagem institucional do Poder Legislativo.

Impende destacar que é vedada a apresentação de denúncia anônima, de modo que, se não houver identificação do denunciante, esta não será recebida (art. 17, § $1^{\circ}$, do Código de Ética). Obviamente, havendo indícios, o Conselho poderá, por conta própria, iniciar a apuração interna, a fim de se verificar a ocorrência de atos ofensivos às regras de decoro.

\subsection{Do exame preliminar da denúncia}

Da mesma forma que ocorre com a representação, uma vez apresentada a denúncia contra senador diante de conduta ofensiva ao decoro parlamentar, o Presidente do Conselho de Ética terá um prazo de 5 (cinco) dias úteis para realizar exame preliminar de admissibilidade da denúncia. Na hipótese de haver falta de legitimidade do autor, ou da própria denúncia não identificar o representado ou os fatos que lhe são imputados, ou, ainda, se os fatos relatados forem referentes a condutas realizadas em período anterior ao mandato, o Presidente determinará o arquivamento da denúncia (art. 17, § 2º, I, II e III, do Código de Ética). Importante ressaltar que, quando o Código de Ética estabelece que será arquivada a denúncia que se referir à conduta anterior ao mandato, tal questão já foi enfrentada em nosso estudo, de modo que a interpretação aqui deve ser no sentido de que será arquivada a denúncia se o agente, no momento da conduta, não estiver sob o influxo do Estatuto Jurídico do Congressista, isto é, não tiver a condição de agente político parlamentar.

A decisão do presidente do Conselho que arquiva a denúncia deverá ser publicada no Diário Oficial do Senado Federal no dia subsequente, a partir do qual se contará o prazo de 2 (dois) dias úteis para a interposição de recurso ao plenário do Conselho, sendo um quesito para o seu recebimento o fato de ser subscrito por, pelo menos, 5 (cinco) membros do Conselho (art. 17, § $3^{\circ}$, do Código de Ética). 


\subsection{Da instauração}

Uma vez preenchidos os requisitos de admissibilidade da denúncia, isto é, o presidente constatando que não há motivos para o arquivamento, será designado por sorteio um relator que realizará sumariamente a verificação das informações, ouvindo o denunciado no prazo de 5 (cinco) dias úteis, contados de sua intimação (art. 17, $\S 4^{\circ}$, do Código de Ética). Ao fim desse prazo, o presidente do Conselho incluirá a matéria na pauta de reunião subsequente, na qual o Plenário do Conselho decidirá pela procedência ou pelo arquivamento da denúncia (art. 17, $\S 5^{\circ}$, do Código de Ética). Se o Plenário do Conselho entender que há elementos comprobatórios suficientes que possam fundamentar a decretação da perda do mandato do denunciado, encaminhará os autos à Mesa para o oferecimento de representação (art. $17, \S 7^{\circ}$, do Código de Ética), já que a Constituição não dá ao Conselho de Ética o poder para provocar a instauração do processo político-disciplinar de perda de mandato. Por óbvio, a subscrição da denúncia por partido político com representação no Congresso Nacional transforma a denúncia em representação.

Relevante ressaltar que a Mesa do Senado, ao receber a denúncia encaminhada pelo Conselho de Ética, não está obrigada a apresentar a representação, da mesma maneira que um partido político que tome conhecimento do conteúdo da denúncia também não o está. Se isso fosse possível, equivaleria dizer que o Conselho de Ética tem competência para provocar a instauração do processo, ferindo o art. $55, \S 2^{\circ}$, da Constituição, que determina essa competência para a Mesa e o partido político com representação no Congresso Nacional. Aliás, se a conclusão de uma denúncia por parte do Conselho de Ética fosse impositiva para a Mesa do Senado ou mesmo para o partido político, obrigando-os a apresentar a representação, não haveria sentido na determinação de envio da denúncia para a Mesa, pois mais fácil seria o próprio Conselho instaurar o processo ao final do trâmite da denúncia.

Com efeito, a Mesa do Senado e o partido político com representação no Congresso poderão decidir sobre a pertinência ou não do oferecimento de representação diante de denúncia que tenha tramitado no Conselho de Ética. Decidindo positivamente nesse sentido, a denúncia transforma-se em representação e retorna ao Conselho. Impende verificar que o art. 17, $\S 9^{\circ}$, do Código de Ética dispõe que, recebida de volta pelo Conselho a denúncia, em 
forma de representação, "será aberto processo disciplinar e expedida notificação específica para o representado, para fins do $\S 4^{\circ}$ do art. 55 da Constituição". Em uma análise rápida dessa disposição, podemos dizer que, quando a representação, oferecida pela Mesa ou por partido político, tiver como origem uma denúncia, nos termos de seu art. 17, caput, do Código de Ética, ao ser apresentada no Conselho gera imediatamente a instauração do processo políticodisciplinar de cassação. De fato, teríamos, assim, dois tipos possíveis de representação, uma cuja origem remonta a uma denúncia que tenha anteriormente tramitado no Conselho de Ética e que, ao ser apresentada no Conselho, impõe imediatamente a abertura do processo, e outra que é elaborada e apresentada de maneira independente pela Mesa ou pelo partido político, visto que, nessa circunstância, não haveria instauração imediata do processo, mas um exame preliminar quanto à admissibilidade da representação, nos termos do art. 14, § 1º, I, II e III, do Código de Ética.

Em conformidade com o que já estudamos, em uma representação que não tenha como fundamento uma denúncia instaurada anteriormente no Conselho de Ética, a abertura do processo ou a sua instauração se dá após uma análise preliminar de admissibilidade feita pelo presidente do Conselho (art. 14, § 1º I, II e III, do Código de Ética) e após a apresentação de uma defesa prévia (art. 15, II, do Código de Ética). O problema que efetivamente se coloca é o seguinte: ao determinar que o Conselho deve abrir imediatamente o processo quando a representação basear-se em denúncia, o Código dá a entender que se deve pular essas fases. A nosso ver, tal interpretação é incorreta. Inspirado somente na letra fria do art. 17 , § $9^{\circ}$, do Código de Ética, devemos compreender que, no retorno da denúncia em forma de representação, o Conselho, ao recebê-la, deverá abrir de imediato o processo, para desencadear todo o procedimento como se fosse uma representação ordinária. Em outras palavras, realizar o exame preliminar de admissibilidade (art. 14, $§ 1^{\circ}$, I, II e III, do Código de Ética), designar relator (art. 15, III, do Código de Ética), determinar a notificação do representado e abrir prazo para apresentação de defesa (art. 15, I, do Código de Ética), que, no caso, não será prévia, mas posterior à instauração do processo. Enfim, deve-se seguir todos os procedimentos que já analisamos quando exploramos a instauração do processo mediante representação no tópico anterior, sendo desnecessário retomar aqui em detalhes seu estudo. Evidentemente, não será preciso que o Plenário do Conselho decida em votação se instaura ou não processo (art. 15-A, 
$\S 1^{\circ}$, do Código de Ética); este, como dita o art. 17, § $9^{\circ}$, já está aberto. Assim, após a apresentação da defesa tem início a fase de instrução.

\subsubsection{Da instrução probatória}

Estando devidamente instaurado o processo disciplinar, tenha ele se originado mediante denúncia ou não, o Conselho procederá às diligências e à instrução que se fizerem necessárias para a elucidação do caso, intimando sempre previamente o representado, para que, querendo, acompanhe todos os atos. Essa intimação poderá ser feita pessoalmente ou por meio do gabinete (art. 17-A do Código de Ética). Deverão ser consideradas e atendidas, desde que pertinentes, as diligências requeridas pelo representante, pelo representado e pelos demais membros do Conselho, lembrando ainda que poderá haver convocação do representado para prestar depoimento pessoal (art. 17-B do Código de Ética). Convém verificar que o Código, ao ditar as regras procedimentais de instrução do processo ético-disciplinar, acaba se referindo ao senador acusado como "representado" e também como "denunciante". O uso deste último termo é incabível, pois, nesse momento, o processo já está instaurado e uma representação foi ofertada ao Conselho, visto que o único termo apropriado é "representado", embora este possa ter tido a qualificação de denunciado em fase anterior.

Note-se que durante a instrução probatória, visando elucidar as situações trazidas pelo processo, o Conselho poderá requerer auxílio de outras autoridades públicas, solicitando informações e, conforme a necessidade, a remessa de documentos, ressalvada a competência privativa da Mesa (art. 19 do Código de Ética).

No caso de inquirição de testemunhas, independentemente do momento no qual se dê a oitiva do representado, este sempre tem o direito de se manifestar depois de colhida a manifestação da testemunha (art. 17-B, parágrafo único, do Código de Ética); assim, o Conselho pode até ouvi-lo antes, mas, após a testemunha falar, estará aberta a possibilidade de sua intervenção.

A condução da produção de prova testemunhal é de competência do presidente, que conduzirá os trabalhos e determinará a forma de sua execução (art. 17-C do Código de 
Ética). ${ }^{308}$ São impedidas de figurarem como testemunhas as pessoas que sejam incapazes, impedidas ou suspeitas, ressalvando que, conforme a necessidade, estas poderão ser ouvidas, mas os seus depoimentos serão prestados independentemente de compromisso, com mero valor informativo (art.17-D do Código de Ética).

Quanto aos documentos que porventura possam auxiliar na elucidação dos fatos sob investigação, a Mesa, o representante e o representado estão autorizados a requerer a sua juntada a qualquer tempo durante a fase de instrução, desde que demonstrada a sua relação lógica com o processo político-disciplinar (art. 17-E do Código de Ética).

$\mathrm{Na}$ fase de instrução, poderá também ser requerida a produção de prova pericial, e uma vez o Conselho de Ética considerando tal procedimento necessário, deverá, em decisão fundamentada, designar o perito (art. 17-F do Código de Ética). Determinada a produção de prova pericial, o relator do processo, conforme entenda oportuno, poderá formular quesitos e pontos a serem esclarecidos na elaboração do laudo, devendo estabelecer prazo para a entrega dos trabalhos e informar imediatamente o especialista designado (art. 17-F, $\S 1^{\circ}$, do Código de Ética). Observe-se que é garantido ao representante e ao representado o direito de apresentar quesitos e também designar assistente técnico no prazo de 3 (três) dias, contados a partir da

\footnotetext{
308 O parágrafo único do art. 17-C do Código de Ética prevê uma ordem de procedimentos a serem seguidos quando da oitiva de testemunha:

"I - serão inquiridas as testemunhas arroladas pelo representante ou denunciante, as convocadas por iniciativa do Conselho e, por último, as arroladas pelo representado ou denunciado;

II - preferencialmente, a inquirição das testemunhas ocorrerá numa única sessão, devendo ficar separadas as de acusação das de defesa e serem recolhidas a lugar de onde não possam ouvir debates nem as respostas umas das outras;

III - a testemunha prestará compromisso e falará somente sobre o que lhe for perguntado, sendo-lhe defesa qualquer explanação ou consideração inicial à guisa de introdução;

IV - ao relator será facultado inquirir a testemunha no início do depoimento e a qualquer momento que entender necessário;

V - após a inquirição inicial do relator, será dada a palavra ao representado ou denunciado ou ao seu procurador para que formule as perguntas que entender necessárias;

VI - feitas as perguntas, será concedido a cada membro do Conselho o prazo de até 10 (dez) minutos improrrogáveis para formular perguntas;

VII - a chamada para que os Senadores inquiram a testemunha será feita de acordo com a lista de inscrição, passando-se a palavra primeiramente aos membros do Conselho e a seguir aos demais Senadores;

VIII - após os titulares e suplentes inquirirem a testemunha, será concedido aos Senadores que não integram o Conselho o mesmo prazo dos seus membros, para suas arguições;

IX - a testemunha não será interrompida, exceto pelo Presidente ou pelo relator;

$\mathrm{X}$ - se a testemunha se fizer acompanhar de advogado, este não poderá intervir ou influir, de qualquer modo, nas perguntas e nas respostas, sendo-lhe permitido consignar protesto ao Presidente do Conselho, em caso de abuso ou violação de direito".
} 
intimação da designação do perito (art. 17-F, § 2º do Código de Ética). Designada data e local para a produção da prova pericial, ao representado deverá ser dado ciência.

Elaborado o laudo pericial, este será entregue na Secretaria do Conselho dentro do prazo fixado pelo relator, podendo o Conselho ainda convocar o perito para prestar pessoalmente os esclarecimentos que se fizerem necessários (art. 17-H, parágrafo único, do Código de Ética).

Finalizada a produção de provas, o relator declarará encerrada a fase de instrução e determinará a intimação do representado para que apresente suas alegações finais no prazo de 3 (três) dias úteis. Terminado o prazo para apresentação das alegações, o relator terá 10 (dez) dias úteis para elaborar relatório para apreciação do Conselho (art. 17-I do Código de Ética). A Secretaria do Conselho, ao receber o relatório, disponibilizará para divulgação apenas sua parte descritiva, deixando sob sigilo até a realização de reunião pública a parte na qual o relator tece análises, isto é, valoriza os elementos descritivos e emite sua opinião final sobre o caso - o seu voto (art. 17-I do Código de Ética). Esse parecer final do relator poderá chegar a duas conclusões: ou será pela procedência da representação, ao oferecer, nessa hipótese, um Projeto de Resolução e decretar a perda do mandato do representado, ou, pelo contrário, será pela improcedência da representação, propondo o seu arquivamento (art. 17-I, § 2º do Código de Ética).

\subsubsection{Da apreciação do parecer}

Na reunião marcada para a apreciação do parecer do relator, após a leitura de sua parte descritiva (relatório), será concedido prazo de 20 (vinte) minutos, prorrogável por mais 10 (dez), para que o representado ou o seu procurador apresente defesa oral, sendo-lhe facultado a entrega prévia de memoriais escritos aos membros do Conselho. Após, o relator fará suas considerações e emitirá o voto sobre o caso (art. 17-O, I, II e III, do Código de Ética).

Lido o voto do relator, inicia-se a discussão do parecer, podendo cada membro do Conselho usar a palavra durante 10 (dez) minutos improrrogáveis. Em seguida, aos demais senadores que não compõem o Conselho será dado mesmo prazo para intervenções (art. 17-O, IV, do Código de Ética). Ao fim dos debates, passa-se à fase de deliberação, na qual os 
membros do Conselho decidem por votação nominal e maioria simples, uma vez que o Código de Ética não indica maiorias específicas, publicando-se o resultado no Diário do Senado Federal (art. 17-O, VI, do Código de Ética). Durante todo o processo de apreciação do parecer, poderá o representado pedir a palavra para esclarecer sucintamente a matéria em discussão (art. 17-O, $\S 1^{\circ}$, do Código de Ética).

Devidamente apreciado o parecer pelo Conselho, este será encaminhado à Comissão de Constituição, Justiça e Cidadania, que terá o prazo de cinco sessões ordinárias para examinar os aspectos constitucional, legal e jurídico (art. 17-O, § $2^{\circ}$, do Código de Ética). Finalizada a tramitação, o processo é enviado à Mesa e, uma vez lido no Expediente, será publicado no Diário do Senado Federal e distribuído em avulsos para inclusão na Ordem do Dia (art. 17-0, § $3^{\circ}$, do Código de Ética).

\subsubsection{Da decisão em Plenário}

$\mathrm{O}$ art. $55, \S 2^{\circ}$, da Constituição Federal dispõe que a cassação de mandato por ofensa ao decoro institucional ocorre por decisão do Plenário da Casa legislativa a que pertencer o parlamentar faltoso. Se for deputado, caberá à Câmara dos Deputados decretar a perda do mandato; em caso de senador, tal incumbência será de competência do Senado Federal. Nunca é demais ressaltar que se trata de competência exclusiva e indelegável. Tem-se, então, que o processo de cassação de mandato por quebra de decoro é cindido em duas partes: na primeira, há a apuração dos fatos, o enquadramento normativo e a indicação não vinculante, conforme o caso, da punição aplicável. No segundo momento, há a decisão da Casa parlamentar. A decisão do plenário em cada uma das Câmaras do Congresso Nacional é a execução concreta dos ditames constitucionais. Como já alertamos, embora constituindo uma decisão de caráter político, a decretação da perda de mandato, nos termos do art. $55, \S 2^{\circ}$, é, antes de tudo, uma competência a ser exercida dentro dos limites do Texto Maior. Destarte, importa a seguir passarmos em revista alguns aspectos constitucionais relevantes quanto à decisão que decreta a perda de mandato por quebra de decoro, focando nossas análises nas regras procedimentais, bem como nos efeitos da decisão. 


\subsubsection{Ampla defesa}

Todo parlamentar submetido a processo de cassação de mandato a ser decido pelo Plenário da Câmara ou do Senado tem assegurado, consoante teor do $\S 2^{\circ}$ do art. 55 da Constituição, o direito de ampla defesa. Com efeito, antes de o plenário da Casa legislativa deliberar sobre a decretação da perda do mandato por ofensa ao decoro, deverá abrir possibilidade para que o parlamentar defenda-se da acusação que lhe é imputada. Pode, então, o deputado ou o senador trazer aos seus pares os argumentos que lhe sejam convenientes diante da acusação que pesa contra si.

O direito de defesa assegurado ao parlamentar no plenário não se confunde com o direito de defesa técnica por intermédio de advogado; afinal, a questão posta à apreciação dos membros do Senado ou da Câmara em processos de cassação de mandato tem caráter eminentemente político, sendo esta precisamente a competência requerida para o momento. No que diz respeito a esse ponto, o Supremo Tribunal Federal definiu não estar obrigada a Câmara ou o Senado a aceitar presença de advogado na tribuna para sustentação oral em defesa de parlamentar submetido a processo de cassação. Nesses termos, temos a seguinte ementa:

Ampla defesa - Parlamentar - Perda de mandato - Representação por advogado no âmbito da Câmara dos Deputados ou do Senado Federal - Sustenção da Tribuna. A expressão "ampla defesa" Contida no $\S 2^{\circ}$ do art. 55 da Constituição Federal não encerra, necessariamente, a representação do parlamentar por profissional da advocacia, a ponto de impor, a qualquer das Casas do Legislativo, a admissão deste na tribuna. O processo de perda de mandato não é administrativo nem judicial, mas político, sendo regido por normas interna corporis. Mesmo no campo jurisdicional, em que se tem o advogado como indispensável à administração da justiça - Art. 133, Capítulo III - “Do Poder Judiciário" - Da Constituição Federal, é possível encontrar recursos que não ensejam a sustentação da Tribuna, sem que, com isto, a norma restritiva possa ser tida como merecedora da pecha de inconstitucional. Tanto quanto possível, deve ser preservada a disciplina do funcionamento dos órgãos dos poderes da União, buscando-se, dessa forma, a eficácia da cláusula constitucional que lhe é inerente - da harmonia e independência. A solução emprestada ao processo político de perda de mandato não obstaculiza o acesso ao judiciário, cuja atuação se faz, sob o ângulo da legalidade, com a inestimável colaboração do 
profissional da advocacia. (Supremo Tribunal Federal, MS 21.360/DF, Rel. Min. Néri da Silveira, $D J$ de 23.04.1993.)

\subsubsection{Votação secreta}

Um dos aspectos mais polêmicos e interessantes sobre o processo de decretação de perda de mandato por quebra de decoro é a previsão constitucional do $\S 2^{\circ}$ do art. 55 , de que a deliberação da Casa congressual seja tomada em votação secreta. Destarte, parece até mesmo contraditória a constatação de que o próprio texto constitucional de 1988, norteado pelos princípios democrático e republicano, determine que os votos emitidos em julgamento político de membro do Poder Legislativo não sejam abertos ao conhecimento público, impondo normativamente o segredo de decisões políticas tomadas no seio do Estado. A vontade dos representantes na formação da decisão da Casa é desconhecida.

Observe-se, então, que a tradição política moderna tem ressaltado exatamente o conhecimento público como uma característica necessária ao Estado Democrático de Direito. Em um Estado fundado no princípio democrático e guiado pela ideia republicana, o direito de saber do cidadão é um elemento político marcante, na medida em que os que exercem o poder não o fazem a título próprio, mas por representação política. $\mathrm{O}$ exercício do poder na esfera pública deve ser feito sob os holofotes da opinião pública, e este é um dos significados da passagem de um Estado de caráter absoluto para um de linhagem representativa. Robespierre traduziu bem essa percepção durante o processo revolucionário francês do século XIX:

\footnotetext{
A nação inteira tem o direito de conhecer a conduta de seus mandatários. Seria preciso, se fosse possível, que a assembleia dos mandatários deliberasse na presença de todos os franceses. Um edifício faustoso e majestoso. Aberto a 12 mil expectadores, deveria ser o local das sessões do corpo legislativo. Sob os olhos de um tão grande número de testemunhas, nem a corrupção, nem a intriga, nem a perfídia ousariam mostrar-se; só a vontade geral seria consultada, só a voz da razão e do interesse público seria ouvida. ${ }^{309}$
}

${ }^{309}$ ROBESPIERRE, Maximilien de. Discursos e relatórios na Convenção. Tradução de Maria Helena Franco Martins. Rio de Janeiro: Contraponto, 1999, p. 104. 
Trilhando este caminho político, a Constituição Federal de 1988 cristaliza no art. 37, caput, a publicidade como um dos princípios regentes da vida estatal brasileira. A atividade do Estado é pautada pelo amplo conhecimento público. Obviamente, esta é a regra, e como tal, sempre comporta, dentro das conveniências constitucionais, exceções. É nesse sentido que devemos compreender e interpretar a sobrevivência de normas como a que insere no na Constituição a votação secreta nas decisões sobre cassação de mandato.

Em excelente passagem, Bobbio explora a questão nos seguintes termos:

Conceitualmente, o problema do caráter público do poder sempre serviu para pôr em evidência a diferença entre duas formas de governo: a república, caracterizada pelo controle público do poder e na idade moderna pela livre formação de uma opinião pública, e o principado, cujo método de governo contempla inclusive o recurso aos arcaria imperii, isto é, ao segredo de Estado que num Estado de direito moderno é previsto apenas como remédio excepcional. [...] Os arcana imperii transformaram-se no segredo de Estado que, na legislação de um moderno Estado de direito, se concretiza ao punir a publicação de atos e documentos reservados; mas com a substancial diferença de que contra o arcanum, considerado como instrumento essencial do poder, e portanto necessário, o segredo de Estado é legitimado apenas nos casos excepcionais previstos pela lei. ${ }^{310}$

É, pois, em regime de excepcionalidade que a Constituição traz regras que garantem o segredo nas decisões políticas tomadas na esfera do Estado. Ressalte-se que o segredo decisório político diz respeito apenas às circunstâncias apontadas expressamente na Constituição, não podendo ser estendido a ponto de abranger situações não previstas no Texto Maior. Note-se que a interpretação dessas regras de segredo das decisões políticas estatais deve ser feita de modo restritivo; dessa forma, a Ministra Cármen Lúcia elucida a questão em julgado do Supremo Tribunal Federal, ao tratar especificamente das votações secretas quando da cassação de mandato parlamentar:

O princípio informador do modelo estatal da República Democrática, constitucionalizado no Brasil em 1988, é o da publicidade e a ele se submetem todos os comportamentos estatais. Daí ter-se por exceção, constitucionalmente expressa, a adoção do regime secreto de votação para a decisão da perda de mandato do parlamentar (Deputado ou Senador), o que somente se dá pelo

310 BOBBIO, Norberto. Estado, governo, sociedade; por uma teoria geral da política. Tradução de Marco Aurélio Nogueira. Rio de Janeiro: Paz e Terra 2007, p. 28-30. 
Plenário da respectiva Casa. Como exceção a interpretação e aplicação haverá de ser restrita, como é próprio dessa condição. (Supremo Tribunal Federal, MS 26.920/DF, Rel. Min. Cármen Lúcia, DJ de 02.10.2007.)

Corroborando com essa linha analítica, o Ministro Carlos Veloso, também em julgado do Supremo Tribunal Federal, assentou que:

... o voto responsável, é o voto querido pela Constituição. O voto secreto é a exceção ao princípio da publicidade. Quanto ao Poder Legislativo, a Constituição não teve postura diversa. A demonstrar que o voto secreto é exceção, deixou a Constituição expressos os casos em que ele ocorreria: art. 52, III e IV: aprovação da escolha de magistrados, ministros do Tribunal de Contas, governador de Território, presidente e diretores do Banco Central, Procurador-Geral da República; art. 52, XI: aprovar a exoneração, de ofício, do Procurador-Geral da República antes do término de seu mandato; art. 53, $\S 3^{\circ}$ : resolver sobre a prisão em flagrante do parlamentar; art. $55, \S 2^{\circ}$ : decretação da perda de mandato do parlamentar; art. $66, \S 4^{\text {o}}$ : apreciação do veto presidencial. Sempre, pois, que a Constituição quis voto secreto, ela foi expressa. Isto não aconteceu ao estabelecer a regra do art. 51, I, onde deixou expresso o quórum qualificado, mas não impôs o voto secreto. (Supremo Tribunal Federal, MS 21.564-0/DF, Rel. Min. Carlos Veloso, DJ de 27.08.1993.)

Devemos observar que o voto secreto na esfera do Poder Legislativo encontra seu fundamento em razões políticas, além de ser vinculado diretamente às relações a que está submetido esse Poder. No caso do segredo nas votações, uma primeira dimensão relacional transparece: o Legislativo é, antes de tudo, um órgão do poder que aparece em pé de igualdade política com outros poderes institucionalizados, isto é, com o Executivo e o Judiciário. É visando garantir sua independência em relação aos outros poderes que se deve garantir o segredo de algumas decisões, isso para evitar que por uma específica tomada de decisão este ou aquele parlamentar sofra eventuais represálias ou perseguições. O parlamentar deve sempre votar com sua consciência na busca do interesse público, sem receios. É de se indagar, todavia, e aqui adentramos mais na seara política do que jurídica, se atualmente é plausível ou desejável manter a deliberação que decreta a perda de mandato parlamentar sob manto protetor do segredo de votação, e isso porque, ao lado da relação que se dá entre os poderes, há aquela que se coloca no plano da representação política, ou seja, no da relação entre representante político e representado. 
Em uma democracia, aqueles que estão no exercício do poder estatal encontram sua legitimidade de atuação na escolha política popular, lócus originário do poder, a teor do parágrafo único do art. $1^{\circ}$ da Constituição de 1988. Tem-se, como já vimos, que a responsabilidade é inerente ao poder democrático e que membros do parlamento respondem por sua atuação. A questão que se coloca, então, diz respeito ao fato de que, para responsabilizar, é importante conhecer as condutas e as posições que tomam os representantes - nessa perspectiva, a discussão pode ser longa e difícil. Sobre o tema, José Eduardo Martins Cardozo, ao relatar na Câmara dos Deputados projeto de Emenda à Constituição que visava abolir o voto secreto nas decisões da Câmara e do Senado, firmou seu entendimento no sentido de que:

O voto secreto era considerado, na sua origem histórica, portanto, uma garantia de preservação do interesse público nas votações congressuais. Por esse motivo foi adotado, também, no Brasil, desde a Constituição do Império (art. 24), para determinadas deliberações legislativas. Hoje, no esteio do Parlamento Europeu e de países como Portugal, Espanha, Itália, Bélgica, França, Dinamarca, Chile, Equador, Peru, México, Costa Rica e República Tcheca, a Constituição Federal de 1988 mantém algumas hipóteses de votações secretas no Legislativo, mais especificamente nos casos de perda de mandato de deputado ou senador, a eleição dos membros das Mesas Diretoras das duas Casas, a eleição ou aprovação de Ministros do Tribunal de Contas, a indicação de presidentes e diretores do Banco Central, do Procurador-Geral da República, de magistrados e de embaixadores, bem como a rejeição dos vetos do Poder Executivo às normas aprovadas no Congresso.

A evolução democrática, porém, impõe nos dias atuais novas exigências e novos imperativos a serem observados na estruturação e na atuação dos Poderes do Estado. Hoje, a transparência e a publicidade dos atos dos agentes públicos colocam-se como exigência impostergável para o exercício da cidadania. São elas as verdadeiras salvaguardas que permitem garantir um controle social efetivo sobre a atividade pública. A opinião pública corrente majoritária é a de que o voto secreto pode ensejar o efeito inverso do propósito original, permitindo que representantes populares transacionem seu apoio a proposições contrárias ao interesse público, na certeza de que seu voto não chegará ao conhecimento de

seus eleitores. Desta maneira, concebido para garantir a independência dos poderes, o voto secreto, ao gerar a impossibilidade do povo conhecer o voto dos seus representantes é que facilitaria a possibilidade desta interferência indevida, por meio de acordos ou negociações espúrias, imorais e ilegítimas.

Ademais, o argumento de que o voto secreto no parlamento garantiria a independência do parlamentar, na medida em que eliminaria a possibilidade de que este viesse a sucumbir diante 
de pressões de outras autoridades ou da própria sociedade é inaceitável nas modernas democracias. Nos dias atuais um parlamentar possui plenas garantias jurídicas que permitem a ele exercer seu mandato com independência, liberdade de consciência e respeito àqueles que o elegeram. Aliás, o conhecimento público de suas opiniões e de seus votos é a melhor garantia contra quaisquer atitudes arbitrárias e ilegítimas a que eventualmente pudesse estar sujeito. Por isso, se no passado era justificada, no atual estágio de evolução democrática em que vivemos a perpetuação do voto secreto se apresenta como inaceitável, comprometendo inclusive a credibilidade do Poder Legislativo perante a sociedade. ${ }^{311}$

De qualquer maneira, para nós interessa apenas constatar que o texto da Constituição não deixa dúvida sobre a legitimidade da votação secreta no caso da cassação de mandato por quebra de decoro parlamentar, como bem diz José Afonso da Silva: "A questão de saber se a votação deve ser secreta ou aberta não oferece dificuldade, porque a Constituição já decidiu como deve ser. [...] $\mathrm{O}$ voto tem que ser secreto. A Casa não pode mudar isso. $\mathrm{O}$ voto aberto está fora de cogitação legítima, por mais que isso possa ser desejável", 312

Vale lembrar que o Supremo Tribunal Federal já firmou ser inconstitucional regra prevista em Constituição Estadual que determine voto aberto quando da cassação de mandato parlamentar a ser decretada pelos pares na respectiva Casa legislativa. Assim, temos a seguinte ementa:

Perda de mandato de parlamentar estadual mediante voto aberto: "Inconstitucionalidade. Violação de limitação expressa ao poder constituinte decorrente dos Estados-membros (Constituição Federal, art. 27, § $1^{\circ} \mathrm{c} / \mathrm{c}$ art. 55, $\S 2^{\circ}$ ). Ação direta de inconstitucionalidade julgada procedente, por maioria. (Supremo Tribunal Federal, ADIn 2.461, Rel. Min. Gilmar Mendes, $D J$ de 07.10.2005.)

\subsubsection{Quórum}

$\mathrm{O}$ art. $55, \S 2^{\circ}$, da Constituição estabelece que a deliberação sobre a cassação de mandato por quebra de decoro parlamentar deverá se dar por maioria absoluta dos membros da

${ }^{311}$ Proposta de Emenda à Constituição n. 349/2001. Disponível em: <http://www.camara.gov.br/proposicoesWeb /fichadetramitacao?idProposicao=273443 >. Acesso em: 20 maio 2011.

${ }^{312}$ SILVA, José Afonso da. Comentário contextual à Constituição. São Paulo: Malheiros, 2010, p. 430. 
respectiva Casa congressual a que pertencer o imputado. Com efeito, na Câmara dos Deputados são necessários 257 votos para que um de seus membros perca o mandato. No Senado Federal, o número requisitado é 41. Sem que se chegue à maioria absoluta dos membros da Casa, não será legítima a decretação da perda do mandato, ensejando a fulminação judicial.

\subsubsection{Efeitos da decisão}

O primeiro efeito evidente da decisão que cassa o mandato do parlamentar por quebra de decoro, nos termos do art. 55, II, $\S 2^{\circ}$, da Constituição, é o desfazimento da relação política, ou seja, o cassado perde o status-jurídico de membro do Poder Legislativo, não estando, por conseguinte, mais submetido às regras estatutárias aplicáveis aos congressistas. Em síntese, não é mais titular de mandato político.

O segundo efeito que decorre da decretação da perda de mandato por violação das normas institucionais de decoro é tornar o mandatário cassado inelegível para cargos eletivos. A Lei Complementar n. 64/90, que regulamenta o art. 14, $\S 9^{\circ}$, da Constituição Federal, estabelece em seu art. $1^{\circ}$ que:

... b) os membros do Congresso Nacional, das Assembleias Legislativas, da Câmara Legislativa e das Câmaras Municipais, que hajam perdido os respectivos b mandatos por infringência do disposto nos incisos I e II do art. 55 da Constituição Federal, dos dispositivos equivalentes sobre perda de mandato das Constituições Estaduais e Leis Orgânicas dos Municípios e do Distrito Federal, para as eleições que se realizarem durante o período remanescente do mandato para o qual foram eleitos e nos oito anos subsequentes ao término da legislatura. 


\section{CAPÍTULO 6 - DO CONTROLE JUDICIAL}

Levando em conta o aspecto político que dá peculiaridade ao instituto da cassação de mandato por quebra de decoro, algumas questões devem ainda ser desenvolvidas. Inicialmente, definimos que o sujeito passivo (agente responsável) nos procedimentos de cassação de mandato por quebra de decoro é sempre um representante político parlamentar. No entanto, pelas próprias características que cercam o instituto, tem-se que, somente um órgão político, no caso a própria Câmara ou o Senado (agente responsabilizador), possui competência para realizar o julgamento, isto é, só o órgão representativo parlamentar tem o legítimo direito de fazer cessar uma relação política de representação sob fundamentos políticos. Em vista disso, podemos concluir com Paulo Brossard que "é natural que do julgamento político, prolatado por uma corporação política, em virtude de causas políticas, ao cabo de processo político, instaurado sob considerações de conveniência política, não haja recurso para o Poder Judiciário", 313

Destarte, observamos uma aparente e inusitada contradição em nossa abordagem, pois, anteriormente, no encadear de nossa análise, tivemos oportunidade de consolidar a ideia de que a cassação de mandato por quebra de decoro, nos termos do art. 55, II, da Constituição da República, configura exercício de função administrativa; logo, controlável pelos órgãos jurisdicionais do Estado. Chegamos, assim, à conclusão de que existem parâmetros jurídicos legais que delimitam o exercício da competência para a decretação da perda de mandato por quebra de decoro e que, uma vez violados esses ditames legais que dão o contorno ao instituto, abre-se a possibilidade de recurso ao Poder Judiciário com base no princípio da inafastabilidade do controle jurisdicional, previsto no art. $5^{\circ}, \mathrm{XXXV}$, da Constituição.

Observe-se que tal caracterização da cassação de mandato está em conflito com sua natureza política. Se a decretação de perda de mandato por quebra decoro envolve uma responsabilização do tipo política, que leva em consideração elementos políticos no fundamento da própria decisão, como poderá o Poder Judiciário interferir nessa avaliação e substituir a apreciação política do Parlamento pela sua? Em julgado emanado pelo Supremo Tribunal Federal, o eminente Ministro Paulo Brossard enfatizava essa distinção de esfera jurídica e política, ao ditar que “... os tribunais julgam segundo critérios de legalidade, e

\footnotetext{
${ }^{313}$ BROSSARD, Paulo. O impeachment, cit., p. 139.
} 
decidir que um procedimento é decoroso ou não transcende os limites da pura legalidade." (Supremo Tribunal Federal, MS 21.443-1 DF, Rel. Min. Octavio Galloti, DJ de 22.04.1992).

Com efeito, o dilema aparente é: ou a cassação é controlável pelos órgãos jurisdicionais e, por isso, diz respeito ao exercício de uma função legalmente estabelecida, ou o controle jurisdicional não é possível por se tratar de matéria política, e qualquer intromissão desse órgão na competência atribuída ao Parlamento implica ofensa ao princípio constitucional da separação de poderes.

Dessa forma, o problema exposto impõe uma espécie de tudo ou nada interpretativo uma vez aceitos o caráter jurídico e a possibilidade do controle jurisdicional, afasta-se a natureza política do instituto e vice-versa. Nesses termos, a discricionariedade é compreendida como um elemento antitético ao Estado de Direito, tendo em vista que nega que todas as manifestações estatais possam estar compreendidas sem resíduos dentro de competências mensuráveis e controláveis judicialmente. ${ }^{314}$ Ao abordar esse tipo de análise, Pedro Lomba afirma que "não são poucos os autores que rejeitam o caráter jurídico da sanção da responsabilidade política". 315

Percebemos nesse dilema claramente o caráter controvertido da responsabilidade política, uma verdadeira quaestio diabolica para o analista jurídico, isso porque a abordagem do tema implica tratar da complexa relação entre direito e política. A discrionariedade é um aspecto extrajurídico que incomoda o objeto científico da análise jurídica, pois, como bem notou Afonso Rodrigues Queiró, a discricionariedade é um elemento central no Estado de polícia absolutista que não deixará de existir no Estado de direito. ${ }^{316}$ Não é por acaso que, em relação à responsabilidade política, se fala em um deficit de análise jurídica ${ }^{317}$ ou em um precário tratamento dado pelo legislador e pela doutrina. ${ }^{318}$

De fato, o paradoxo a que chegamos é fruto de uma interpretação que delimita abstratamente em excesso a esfera da política e do direito, pois que, na dinâmica constitucional concreta, nem um ato estatal aparece como puramente político, razão pela qual

\footnotetext{
${ }^{314}$ SCHMITT, Carl. Teoria de la constitución, cit., p. 142.

${ }^{315}$ LOMBA, Pedro. Teoria da responsabilidade política, cit., p. 40.

${ }^{316}$ QUEIRÓ, Afonso Rodrigues. Estado-polícia, Estado de direito e poder discricionário. Coimbra: Coimbra Editora, 1989. v. I: Estudos de Direito Público, p. 86.

${ }^{317}$ LOMBA, Pedro Teoria da responsabilidade política, cit., p. 20.

${ }^{318}$ CUNHA, Sérgio Sérvulo da. Fundamentos de direito constitucional, cit., p. 395.
} 
Rui Barbosa denunciava como artificiosa essa distinção entre questões políticas e jurídicas. ${ }^{319}$ Como assevera Jorge Miranda, "não há atividade do Estado à margem do Direito". ${ }^{320} \mathrm{Se}$, historicamente, o constitucionalismo tem o sentido de uma racionalização, moderação e limitação do poder político, ${ }^{321}$ é preciso determinar a liberdade de avaliação política como algo dentro de parâmetros normativos; caso contrário, estaremos não diante de um poder discricionário, mas arbitrário. Ocorre, nesse ponto, uma distinção entre poder exercido de forma arbitrária e poder limitado, exercido com base em parâmetros normativos. Pontes de Miranda, atento ao problema, destacou que 'toda discricionariedade é interior, é 'dentro'; nesse branco, que as raias das atribuições concedem, é que o aspecto ou a dimensão é só concernente à política". 322

Com efeito, devemos considerar a cassação de mandato por quebra de decoro como um instituto de natureza dúplice: jurídico-política. ${ }^{323}$ Impende, então, compreender essa natureza a partir da própria perspectiva do regime jurídico administrativo, o que pode ser feito pela aproximação entre discricionariedade política e administrativa.

A liberdade que goza o Poder Legislativo nas decisões de perda de mandato por ofensa ao decoro não difere em essência daquela que existe nos atos administrativos discricionários realizados no âmbito da Administração, embora não possa ser completamente nivelada. Por vezes, ao administrador é atribuído pela lei certo grau de liberdade para decidir sobre a conveniência e a oportunidade de determinadas ações; nessas situações, diz-se que há competência discricionária, mas, mesmo nesses casos, "existe uma parcela de vinculação por normas jurídicas - uma parcela de normatividade". ${ }^{324}$

O que a doutrina administrativista nomeia como discricionariedade é, antes de tudo, uma liberdade ancorada em balizas jurídicas. Costuma-se, então, falar em uma face legal ou de legitimidade do ato administrativo e outra discricionária ou de mérito. Um aspecto político e um jurídico que caminham juntos. Nesse sentido, "o mérito do ato é a medida da discrição"; 325

\footnotetext{
${ }^{319}$ BARBOSA, Ruy. Comentários à Constituição Federal brasileira. São Paulo: Saraiva, 1933. v. 4, p. 42.

${ }^{320}$ MIRANDA, Jorge. Funções do Estado, cit., p. 88.

${ }^{321}$ LOEWENSTEIN, Karl. Teoría de la constitución, cit., p. 68.

${ }^{322}$ MIRANDA, Pontes. Comentários à Constituição de 1967 com a Emenda n. 1, de 1969, cit., p. 643. Ver também: TEIXEIRA, José Elaeres Marques. A doutrina das questões políticas no Supremo Tribunal Federal. Porto Alegre: Fabris Editor, 2005, p. 59.

${ }^{323}$ CARDOZO, José Eduardo Martins. Consulta n. 001/2007, cit., p. 24.

${ }^{324}$ QUEIRÓ, Afonso Rodrigues. Teoria dos actos de governo, cit., p. 519.

${ }^{325}$ FAGUNDES, M. Seabra. Conceito de mérito no direito administrativo. Rio de Janeiro: Revista de Direito Administrativo, 1951, p. 12.
} 
logo, a conveniência e a oportunidade, o caractere da liberdade do ato, têm uma medida, um limite e certo aspecto de mensurabilidade jurídica. A discricionariedade aqui já não configura uma oposição ao Estado de Direito; pelo contrário, consubstancia elemento essencial na concretização da ordem jurídica em sua dinâmica. ${ }^{326}$

Destarte, no que concerne à legalidade, o ato discricionário é plenamente controlável pelo Poder Judiciário. Contudo, no que tange ao mérito da decisão, naquele espaço de conveniência e oportunidade atribuído ao administrador, está o Poder Judiciário impedido de substituir o juízo realizado, sob pena de usurpar competência determinada para outro Poder estatal, ferindo, assim, o princípio da separação de poderes (art. $2^{\circ}$ da Constituição Federal/88).

Seabra Fagundes acentua, nessa perspectiva, que:

Sem dúvida, a atividade chamada discricionária se submete à lei. Tem por esta demarcadas as divisas do seu exercício, submete-se às linhas mestras que esta prefixa. Dentro, porém, dessas divisas ou dessas linhas, é livre (e aqui está a própria essência da discricionariedade), exercitase sob a influência apenas de razões políticas. É neste plano de insujeição da atividade administrativa a normas propriamente jurídicas, que discrição e mérito se identificam. ${ }^{327}$

Aplicados tais aspectos analíticos à cassação de mandato por quebra de decoro, concluímos que deputados e senadores são livres para sobrepesar e avaliar politicamente se algum par procedeu de forma ofensiva à dignidade do Parlamento e decidir sobre a perda do mandato do respectivo. Nesse espaço aberto pela norma constitucional, move-se a Casa parlamentar com competência exclusiva. O juízo político não pode ser exercido pelo Poder Judiciário - embora este tenha competência para controlar desvios e ilegalidades, encontra na questão política um óbice para manifestar sua posição (self-restraint). A questão exclusivamente política ou puramente política diz respeito ao mérito do ato, à sua discricionariedade.

Corroborando essa tese, trazemos a seguir duas ementas de julgados do Supremo Tribunal Federal:

${ }^{326}$ QUEIRÓ, Afonso Rodrigues. Estado-polícia, Estado de direito e poder discricionário, cit., p. 88.

${ }^{327}$ FAGUNDES, M. Seabra. Conceito de mérito no direito administrativo, cit., p. 12. 
Inviável qualquer controle sobre o julgamento do mérito da acusação feita ao impetrante, por procedimento incompatível com o decoro parlamentar. (Supremo Tribunal Federal, MS 21.861/DF, Rel. Min. Néri da Silveira, DJ de 21.08.2001.)

Cassação de mandato parlamentar. Mandado de segurança de que não conhece, na parte referente à qualificação do fato tido como indecoroso. Pedido, no restante, indeferido, por não se demonstrar o alegado cerceamento de defesa. (Supremo Tribunal Federal, MS 23.529/DF, Rel. Min. Octavio Gallotti, DJ de 23.03.2001.)

Saliente-se, então, que, como o procedimento de cassação por quebra de decoro configura uma competência normativamente determinada (art. 55, II, da Constituição Federal), o seu exercício deve respeitar os parâmetros delineados no Texto Maior, sendo que qualquer ultrapassagem dos limites estabelecidos torna possível o recurso ao Poder Judiciário, que, nesse caso, é competente para manifestar seu juízo. Ruy Barbosa fixou sua compreensão sobre as questões políticas precisamente nessa linha: "se a autoridade invoca uma atribuição inexistente ou exorbita de uma atribuição existente, embora discricionária dentro dos seus limites, não pode a justiça recusar o socorro legal ao direito do indivíduo ou do Estado, que para ela apelar". ${ }^{328}$ Destarte, ao parlamentar atingido pela cassação de mandato por quebra de decoro é lícito recorrer ao Poder Judiciário para ver apreciada a legalidade e a legitimidade do ato que decretou a perda de seu mandato. Sobre esse caso, assentou Pinto Ferreira que "prevalece em toda a sua magnitude e grandeza do preceito constitucional do Estado de Direito, qual seja, o preceito constitucional da inafastabilidade do controle judicial (art. $5^{\circ}$, XXXV, da Constituição Federal )". 329

Não menos elucidativas são as palavras de José Eduardo Martins Cardozo, ao analisar os limites do Parlamento quando do exercício da competência estabelecida no art. 55, II, da Constituição da República:

... este juízo decisório somente poderá ser tomado a partir da prefiguração dos pressupostos jurídicos delineados pelas normas de Direito em vigor, dentre os quais se destacam nesse momento, dentre outros, a ocorrência provada do fato tipificador da falta de decoro parlamentar (motivo), o respeito ao quorum decisório exigido e às regras de tramitação, ao princípio do

${ }^{328}$ BARBOSA, Ruy. Comentários à Constituição Federal brasileira, cit., p. 44.

${ }^{329}$ FERREIRA, Pinto. Comentários à Constituição brasileira, cit., p. 26. 
contraditório e da ampla defesa, e a observância de todos os demais aspectos da tramitação regimentalmente estabelecidos (requisitos procedimentais e formalização dos atos). ${ }^{330}$

Respeitados os parâmetros constitucionais, não haverá manifestação do Poder Judiciário sobre a justiça ou injustiça da medida política; nesse sentido, pode-se falar que, no mérito ou em seu caráter puramente político, a cassação de mandato por quebra de decoro configura um ato interna corporis (enquanto expressão particularizada de uma competência política), diga-se, que só diz respeito ao próprio órgão emanador do ato, único constitucionalmente competente para prolatá-lo, sendo expressão da própria autonomia e independência do Poder Legislativo. Paulo Brossard assevera que, "observadas as formalidades constitucionalmente enunciadas, a decisão, da Câmara ou do Senado, poderá ser discutível, poderá ser injusta, poderá ser desacertada, mas será definitiva e irrecorrível; será insuscetível de revisão judicial" (Supremo Tribunal Federal, MS 21.443-1 DF, Rel. Min. Octavio Galloti, DJ de 22.04.1992). Devemos entender aqui o caráter de injusto como um elemento subjetivo, e não como uma ilegalidade ou ofensa à Constituição.

Note-se que não existe matéria política insindicável pelo Poder Judiciário a priori; pelo contrário, o que pode ser considerado regra apriorística é a inafastabilidade do controle jurisdicional, consoante teor do art. $5^{\circ}, \mathrm{XXXV}$, de nossa Carta Republicana, como já tivemos oportunidade de deixar assentado. Toda competência exercida, mesmo com a qualidade de um alto grau de discricionariedade, que é o caso da cassação de mandato por quebra de decoro, pode ser levada ao Judiciário, e é nessa instância que deverá surgir, a partir da análise dos pressupostos jurídicos do ato, aquilo que a doutrina nomeia como questão política. O mérito da cassação só pode ser mantido imune à atuação judicial se no exercício da competência se respeitou a Constituição e as determinações legais; caso contrário, cabe ao Poder Judiciário sustar os efeitos do ato.

Nesses termos, são prudentes as palavras do nobre Ministro Celso de Mello:

É por essa razão que os atos interna corporis, contudo - não obstante abrangidos pelos círculos de imunidade que excluem, em princípio, a possibilidade de sua revisão judicial -, não podem ser invocados, com essa qualidade e sob esse color, para justificar a ofensa a direito público

${ }^{330}$ CARDOZO, José Eduardo Martins. Consulta n. 001/2007, cit., p. 22. Ver, no mesmo sentido, MEIRELLES, Hely Lopes. Direito municipal brasileiro. São Paulo: Malheiros, 2008, p. 715. 
subjetivo que terceiros, inclusive os próprios parlamentares, titularizam. (Supremo Tribunal Federal, MS 22.494-1, Rel. Min. Maurício Corrêa, DJ de 19.12.1996.)

\section{Reforçando esse entendimento, embora se referindo à conjuntura constitucional} passada, de 1946, temos as excelentes análises de Nelson Hungria:

Tenho para mim que é insustentável a tese acórdão recorrido, segundo a qual não há indagar, sequer, se está comprovado o procedimento reputado incompatível com o decoro parlamentar. Redundaria isso no reconhecimento do mais descontrolado arbítrio, flagrantemente irreconciliável com o art. 141, § $4^{\circ}$, da Constituição, desde que esteja em jogo a violação de direito individual. Em matéria de questões de natureza política, a apreciação destes pelo Poder Judiciário se impõe independentemente de tal natureza toda vez que envolvam a lesão de um direito subjetivo individual [...]. Na espécie, a própria exigência legal do motivo de incompatibilidade do procedimento do senador, deputado ou vereador com o decoro parlamentar, está a evidenciar que não se trata de ato puramente arbitrário, em mesmo apenas discricionário. Não é exato que o reconhecimento dessa incompatibilidade atende ao critério meramente subjetivo. Admiti-lo valeria por admitir, obliquamente, o arbítrio que a Constituição e a lei ordinária repelem. (Supremo Tribunal Federal, Rel, Min. Nelson Hungria, Mandado de Segurança n. 2.319, julgado em 05 de janeiro de 1954.)

Resulta dessas análises que não se pode invocar a natureza interna corporis $^{331}$ do processo da cassação de mandato por quebra de decoro para encobrir comportamentos arbitrários e ilegítimos - os argumentos e posições doutrinárias e jurisprudências que trouxemos aqui fundamentam posição oposta a essa.

Após toda essa análise, podemos concluir que a cassação de mandato por quebra de decoro tem uma natureza dúplice, uma face política, evidenciada pela discricionariedade do ato, e outra jurídica, que se revela na ideia de que o instituto perfaz uma competência constitucional exercida no âmbito de uma função estatal: a função administrativa. Assim, pode-se falar de um caráter político disciplinar, político administrativo ou político jurídico, exatamente para representar essas duas dimensões do instituto.

331 Entenda-se por natureza interna corporis "um ato que por natureza regula a própria vida parlamentar" (BASTOS, Celso Ribeiro; MARTINS, Ives Gandra. Comentários à Constituição do Brasil. São Paulo: Saraiva, 1999. v. 4, t. I, p. 221), logo dizendo respeito a uma competência que é determinada pela Constituição visando garantir a independência entre os poderes do Estado, perfazendo, assim, uma competência política. 


\section{CONCLUSÃO}

Ao início do presente trabalho, propusemo-nos explorar os elementos jurídicos caracterizadores do instituto da cassação de mandato parlamentar por quebra de decoro, apontando o art. 55, II, da Constituição de 1988 como o objeto fundamental de análise. Em nossa trajetória analítica, verificamos que foi a Constituição de 1946 que albergou, pela primeira vez, o referido instituto em nosso ordenamento jurídico, prevendo em seu art. $48, \S$ $2^{\circ}$, a perda do mandato para deputado ou senador cujo procedimento fosse reputado, pelo voto de dois terços dos membros de sua respectiva Casa legislativa, incompatível com o decoro parlamentar. A perda do mandato por ofensa ao decoro tinha, nesse contexto histórico, um claro sentido de defesa da legitimidade política do Poder Legislativo, atuando como um instrumento garantidor da moralidade parlamentar com o intuito de manutenção de sua imagem diante dos cidadãos. Aquele representante popular que não agisse de modo digno com a função parlamentar poderia ter seu mandato cassado conforme consideração política de seus pares. Sob a vigência da Constituição de 1946, tal instrumento foi utilizado apenas uma única vez, voltando a vigorar em regime democrático novamente a partir de nossa Constituição da República de 1988, com os contornos que lhe foram dados no art. 55, II.

Atualmente, a cassação de mandato por quebra de decoro parlamentar é um dos instrumentos mais importantes para a defesa da moralidade institucional do Poder Legislativo, pois abre possibilidade de os próprios membros do Legislativo retirarem de seu meio o par que se comporte de modo ofensivo à dignidade e ao prestígio da função parlamentar. Assim, fica evidente o caráter punitivo da cassação, ou seja, trata-se de uma forma de responsabilização política realizada pelos próprios representantes do povo.

Nessa ordem de ideias, o instrumento punitivo prescrito no art. 55, II, da Constituição traz impacto relevante do ponto de vista democrático, já que tem por efeito concreto o desfazimento de uma dada relação democrática, diga-se, desfaz aquilo que foi constituído por meio do voto, que é a eleição do representante. Não por outra razão, o exercício dessa competência constitucional pelos membros do Poder Legislativo deve se dar em consonância com os termos do próprio Texto Maior como um todo - é dentro dessa perspectiva que buscamos identificar os elementos caracterizadores da cassação de mandato por quebra de decoro. 
O instrumento da cassação de mandato por ofensa ao decoro parlamentar, nos termos previstos no art. 55, II, da Constituição, estabelece uma forma de responsabilização excepcional somente os casos que impliquem evidente macula à dignidade institucional e nos quais ocorra risco à legitimidade do poder, devendo ser punidos com a perda de mandato. Em síntese, a cassação de mandato por quebra de decoro não é uma arma constitucional colocada à disposição dos combatentes políticos no campo do Poder Legislativo, de forma que estes possam utilizá-la de acordo com seu livre-arbítrio, mas é instrumento de garantia institucional quando esta se vê ameaçada em sua imagem pública, isto é, o instituto tem finalidade específica e limitada, para além dos seus fins há apenas desvio e abuso.

A partir da perspectiva exposta anteriormente tecemos todas as nossas considerações sobre o instituto e, nesse caminho, muitos foram os dilemas teóricos jurídicos enfrentados. $\mathrm{O}$ primeiro desafio foi, de um lado, determinar um conteúdo mínimo para o conceito de decoro e, de outro, enquadrar o processo de cassação dentro das categorias jurídicas existentes, isto é, determinar a sua natureza jurídica.

Sobre a definição do comportamento ofensivo ao decoro, observamos que, embora constitua um conceito fluído e de difícil determinação, isso não impede que tenhamos ideias mínimas e parâmetros sobre o seu conteúdo, o que pode ser desde início encontrado na própria Constituição e nas regras infraconstitucionais. Nesse aspecto, o que nos pareceu relevante foi deixar assente que ato ofensivo ao decoro parlamentar não é aquilo que os membros de determinada Casa legislativa assim decidam que seja, mas, sim, aquilo que ofenda objetivamente a moralidade institucional do Poder Legislativo. A Constituição, no $\S 1^{\circ}$ do art. 55, já induz um mínimo de compreensão ao impor como comportamentos indecorosos o abuso de prerrogativas e a percepção de vantagens indevidas por parte de agente parlamentar.

Nesse passo, ressaltemos, então, que a Constituição não impôs de forma taxativa e objetiva o que seja comportamento ofensivo ao decoro, e isso para possibilitar a análise segundo a situação enfrentada em cada tempo histórico pelo Poder Legislativo. A ideia de decoro diz respeito a um conceito sócio-histórico e, por isso, mutável conforme o desenvolvimento de determinada sociedade em certo tempo.

Quanto ao instrumento constitucional da cassação de mandato por quebra de decoro, exploramos sua essência jurídica constatando que se trata de um processo de natureza políticodisciplinar de caráter administrativo, exibindo, assim, uma dupla face quanto a sua natureza, 
uma na qual se revela o aspecto político consubstanciado no julgamento ético realizado pelos pares parlamentares e outra na qual o aspecto jurídico se sobressai, impondo que todo o caminhar do processo se dê com base em limites legais. Assim, se por um lado os membros da Câmara ou do Senado têm ampla liberdade de apreciação quanto à ocorrência e aplicação da pena de cassação de mandato por quebra de decoro, por outro deve seguir parâmetros legais mínimos, como garantir ao parlamentar acusado o direito à ampla defesa e ao contraditório.

A partir dessas características gerais concluímos que o Poder Judiciário está apto a exercer controle de legalidade dos processos de cassação de mandato que tenham por base o art. 55, II, da Constituição, estando apenas vedado a esse Poder a análise quanto ao mérito político da decisão tomada pelos membros do Legislativo. A Constituição remete apenas ao Poder Legislativo o poder para realizar julgamento político sobre a ofensa ao decoro parlamentar, ou seja, não poderia o Judiciário tomar tal decisão sem violar o princípio constitucional da separação de poderes.

Procuramos deixar claro também que, para abertura do processo de cassação por quebra de decoro, alguns requisitos ou condições mínimas devem estar presentes, a fim de que o instrumento da cassação não resulte na mais pura injustiça diante da Constituição. Um exemplo desses requisitos mínimos é a existência efetiva do fato imputado como ofensivo ao decoro - com efeito, se é de notório conhecimento que o comportamento considerado como ofensivo ao decoro não ocorreu concretamente, não se pode abrir processo de cassação com base no art. 55, II, da Constituição.

Outra condição importante para a instauração do processo de cassação é a de que o acusado esteja no exercício de mandato parlamentar; afinal, seria no mínimo ilógico imaginar um processo de cassação de mandato aberto contra quem mandato nenhum exerce. Não havendo mandato, perde-se o objeto da cassação. Sobre essa última situação sempre se coloca a questão da renúncia ao mandato, já que, nesse caso, o parlamentar perde sua condição de mandatário, fato que impede a continuidade ou a eventual instauração do processo de cassação.

Consoante vimos o exercício do direito de renúncia ao mandato para ter eficácia, isto é, para produzir todos os seus efeitos de direito após manifestação do parlamentar, este deve ocorrer antes que haja qualquer processo que tenha por objetivo ou que possa eventualmente levar à perda do mandato. Na hipótese de a renúncia ocorrer depois de instaurado o processo, 
seus efeitos ficam suspensos até a deliberação final quanto à existência ou não da quebra de decoro, é esta a determinação contida no $\S 4^{\circ}$ do art. 55 da Constituição.

Importante ressaltar que grande discussão havia e ainda há quanto à adoção de um critério definidor do momento em que se dá a instauração do processo que leve ou possa levar à perda do mandato, uma vez que a resolução dessa questão importa na determinação do momento a partir do qual o parlamentar poderia ou não renunciar ao seu mandato sem ser atingido pelo $\S 4^{\circ}$ do art. 55 da Constituição. Alguns entendiam que apenas existia processo propriamente dito após o oferecimento formal de representação no Conselho de Ética de uma das Casas legislativas, enquanto outros, de maneira distinta, solucionavam o problema defendendo a ideia de que a existência de qualquer apuração sobre falta de ética no âmbito no Poder Legislativo era circunstância suficiente para obstar a eficácia de eventual pedido de renúncia por parte de parlamentar. No centro desse debate estava a necessidade de impedir que o parlamentar faltoso fugisse de sua responsabilidade diante de seus pares.

Em realidade, quando o parlamentar renuncia ao mandato quer apenas manter incólume seu direito de ser votado em pleito eleitoral, isso porque a eventual cassação de mandato por quebra de decoro gera o fenômeno da inelegibilidade para o punido, segundo art. $1^{\circ}$, I, $b$, da Lei Complementar n. 64/90. Embora todo esse debate ainda tenha importância, tendo em vista as repercussões políticas envolvidas, parece-nos que, sob um aspecto, a questão se encontra resolvida - a renúncia não tem mais o condão de evitar a inelegibilidade, pois, atualmente, ela configura uma hipótese de inelegibilidade consoante previsto no art. $1^{\circ}, \mathrm{I}, k$, da Lei Complementar n. 64/90, alterada pela Lei Complementar n. 135/2010.

Outras duas situações de difícil solução envolvendo as condições para a abertura do processo de cassação de mandato que enfrentamos foram: a do parlamentar reeleito para um segundo mandato e que tenha cometido falta de decoro em mandato anterior; e a do parlamentar que comete ato ofensivo à moral em momento anterior ao exercício de qualquer mandato.

Quanto à primeira situação adotamos a seguinte posição: se o comportamento passível de ser qualificado como indecoroso não era conhecido de maneira ampla pela opinião pública no momento em que o parlamentar foi reeleito, a Casa legislativa a que este pertencer estará apta a abrir procedimento de cassação de seu mandato, isso porque os cidadãos eleitores não tiveram oportunidade de avaliar o comportamento imoral do parlamentar. Todavia, se a 
situação era inequivocamente de conhecimento público e, mesmo assim, o deputado ou senador foi reeleito para um segundo mandato, será do ponto de vista jurídico e político inconveniente a instauração do processo, pois deve se presumir que a decisão popular foi tomada com pleno conhecimento da situação que envolvia o agente político, não podendo os representantes do povo desfazer aquilo que os donos da soberania popular decidiram. Trata-se de respeitar os ditames do art. $1^{\circ}$, parágrafo único, da Constituição, que considera o povo titular primeiro da soberania.

No que atina à hipótese do parlamentar que cometeu atos ofensivos ao decoro em período anterior ao exercício de qualquer mandato legislativo, polemicamente nos pareceu prudente defender a posição de que só quebra o decoro parlamentar que se encontra submetido ao Estatuto do Congressista. Assim, quem não era representante do povo no momento da conduta não pode, posteriormente, tendo em vista a eleição para o cargo de deputado ou senador, ser punido nos termos do art. 55, II, da Constituição.

Esses são, a nosso ver, os pontos centrais das análises que realizamos ao longo do percurso de pesquisa, todos desenvolvidos a partir da perspectiva de que é necessário garantir a integridade institucional do Poder Legislativo, sem, contudo, sacrificar o princípio da soberania popular, e aqui estamos sempre diante de problemas de difícil solução.

Por fim, importa observar que vivenciamos nos tempos atuais o que podemos nomear como fenômeno da politização da moral, isto é, a situação na qual os resultados da luta política dependem do desempenho moral de seus contendores, e tal constatação por si só já é motivo suficiente para atentarmos a um uso mais razoável e lógico do instrumento da cassação de mandato parlamentar por quebra de decoro. 


\section{REFERÊNCIAS}

ALTHUSSER, Louis. Montesquieu, la política y la historia. Madrid: Editorial Ciencia Nueva, 1968.

ALVIM, Arruda. Manual de direito processual civil. São Paulo: Revista dos Tribunais, 2008.

AMARAL, Roberto; CUNHA, Sérgio Sérvulo da. Manual das eleições. São Paulo: Saraiva, 2006.

ATALIBA, Geraldo. República e constituição. São Paulo: Malheiros, 2007.

AVRIL, Pierre; GICQUEL, Jean. Droit parlementaire. Paris: Montchrestien, 2004.

AZEVEDO, José Affonso Mendonça de. Elaborando a constituição nacional - atas da subcomissão elaboradora do Anteprojeto 1932/1933. Edição Fac-similar. Brasília: Senado Federal, 2004.

BARBOSA, Ruy. Comentários à Constituição Federal brasileira. São Paulo: Saraiva, 1933, v. 2.

BARBOSA, Ruy. Comentários à Constituição Federal brasileira. São Paulo: Saraiva, 1933. v. 4.

BASTOS, Celso Ribeiro; MARTINS, Ives Gandra. Comentários à Constituição do Brasil. São Paulo: Saraiva, 1999. v. 4, t. I.

BIM, Eduardo Fortunato. A cassação de mandato por quebra de decoro parlamentar. Sindicabilidade, jurisdicional e tipicidade. Brasília: Revista de Informação Legislativa, v. 43, n. 169, jan./mar. 2006.

BOBBIO, Norberto. Estado, governo, sociedade: por uma teoria geral da política. Tradução de Marco Aurélio Nogueira. Rio de Janeiro: Paz e Terra, 2007.

BOBBIO, Norberto. Estado, governo, sociedade: para uma teoria geral da política. Tradução de Marco Aurélio Nogueira. Rio de Janeiro: Paz e Terra, 2010.

BONAVIDES, Paulo. Ciência política. São Paulo: Malheiros, 2003.

BONAVIDES, Paulo. Curso de direito constitucional. São Paulo: Malheiros, 2008.

BONAVIDES, Paulo; ANDRADE, Paes de. História constitucional do Brasil. Brasília: Paz e Terra, 1989.

BOURDIEU, Pierre. O poder simbólico. Rio de Janeiro: Bertrand Russel, 1998.

BROSSARD, Paulo. O impeachment. São Paulo: Saraiva, 1992. 
BULOS, Uadi Lammêgo. Curso de direito constitucional. São Paulo: Saraiva, 2011.

BURKE, Edmund. Discurso aos eleitores de Bristol. Tradução de Cid Knipell Moreira. In:

WEFFORT, Francisco C. (Org.). Os clássicos da política 2. São Paulo: Ática, 1995.

CAGGIANO, Monica Heman Salem. Direito parlamentar e direito eleitoral. São Paulo: Manole, 2004.

CAGGIANO, Monica Heman Salem. Eleições 2002: o financiamento das campanhas eleitorais e seu controle. Enquadramento jurídico. São Paulo: Revista de Direito Mackenzie, ano 1, n. 1, jan./jun. 2000.

CAGGIANO, Monica Heman Salem. Oposição na política. São Paulo: Angelotti, 1995.

CALIMAN, Auro Augusto. Mandato parlamentar: aquisição e perda antecipada. São Paulo: Atlas, 2005.

CALIMAN, Auro Augusto. O recall no Estado de São Paulo. Brasília: Revista de Informação Legislativa, 2005.

CANOTILHO, J. J. Gomes. Constituição dirigente e vinculação do legislador. Coimbra: Coimbra Editora, 2001.

CANOtIlHO, J. J. Gomes. Direito constitucional e teoria da Constituição. Coimbra: Almedina, 2002.

CARDOZO, José Eduardo Martins. A crise do legislativo. São Paulo: Revista de Estudos Avançados da Universidade de São Paulo, n. 67, 2009.

CARDOZO, José Eduardo Martins. Consulta n. 001/2007. Conselho de Ética e Decoro Parlamentar da Câmara dos Deputados. Cadernos de Pós-Graduação em Direito: estudos e documentos de trabalho, n. 4. Comissão de Pós-Graduação da Faculdade de Direito da USP. São Paulo: Manole, 2011.

CAVAlCANTI, Themistocles Brandão. A Constituição Federal comentada. Rio de Janeiro: José Konfino, 1948. v. II.

CRETELLA JÚNIOR, José. Comentários à Constituição brasileira de 1988. Rio de Janeira: Forense Universitária, 1992. v. V.

CUNHA, Sérgio Sérvulo da. Fundamentos de direito constitucional. São Paulo: Saraiva, 2008. v. 1 e 2 .

DAHL, Robert. Poliarquia: participação e oposição. São Paulo: Edusp, 1997.

DALLARI, Dalmo de Abreu. Elementos de teoria geral do Estado. São Paulo: Saraiva, 2009. 
DI PIETRO, Maria Sylvia Zanella. Direito administrativo. São Paulo: Atlas, 2006.

DI RUFFIA, Paolo Biscaretti. Direito constitucional: instituições de direito público. São Paulo: Revista dos Tribunais, 1984.

DINAMARCO, Candido Rangel. Instituições de direito processual civil. São Paulo: Malheiros, 2004. v. I.

DORIA, A. de Sampaio. Direito constitucional. Teoria geral do Estado. São Paulo: Max Limonad, 1962. v. I, t. II.

DORIA, A. de Sampaio. Direito constitucional: comentários à Constituição de 1946. São Paulo: Max Limonad, 1960. v. 2.

DUGUIT, Léon. Traité de droit constitutionnel. Paris: Ancienne Librairie Fontemoing \& Cie/E. de Boccard, 1924.

DUSSEL, Enrique. 20 Teses de política. Buenos Aires: Consejo Latinoamericano de Ciências Sociales - CLASCO. São Paulo: Expressão Popular, 2007.

DUVERGER, Maurice. Apogeo y declinácion del sistema parlamentario. In: DUVERGER, Maurice; BRIDIER, Manuel. El sistema parlamentario. El poder real. Buenos Aires: Schapire Editor, 1973.

DUVERGER, Maurice. Cours de droit constitutionnel. Paris: Librairie Du Recueil Sirey, 1946.

DUVERGER, Maurice. Metodos de las ciências sociales. Barcelona: Ariel, 1980.

ELAERES, José Marques Teixeira. A doutrina das questões políticas no Supremo Tribunal Federal. Porto Alegre: Fabris Editor, 2005.

ENTERRÍA, Eduardo Garcia. El principio de "la responsabilidad de los poderes públicos" según el art. 9.3 de la Constittución y la responsabilidad patrimonial del estado legislador. Revista de Derecho Constitucional, año 23, n. 67, enero/abr. 2003.

FAGUNDES, M. Seabra. Conceito de mérito no direito administrativo. Rio de Janeiro: Revista de Direito Administrativo, 1951.

FAORO, Raymundo. Os donos do poder. São Paulo: Globo, 2008.

FARIA, José Eduardo Faria. O direito na economia globalizada. São Paulo: Malheiros, 2002.

FARIA, José Eduardo. Poder e legitimidade. São Paulo: Perspectiva, 1978. 
FEREJOHN, John Accountability and authority: toward a theory of political accountability. In: MANIN, Bernard; PRZEWORSKI, Adam; STOKES, Susan C. Democracy, accoutability and representation. Cambridge: Cambridge University Press, 2003.

FERRAZ JR. Tércio Sampaio. Introdução ao estudo do Direito: técnica, decisão, dominação. São Paulo: Atlas, 2007.

FERREIRA, Pinto. Código eleitoral comentado. São Paulo: Saraiva, 1998.

FERREIRA, Pinto. Comentários à Constituição brasileira. São Paulo: Saraiva, 1990. v. 2.

FERREIRA, Pinto. Comentários à Constituição brasileira. São Paulo: Saraiva, 1992. v. 3.

FERREIRA, Pinto. Teoria geral do Estado. São Paulo: Saraiva, 1975. v. I.

FERREIRA FILHO, Manoel Gonçalves. A corrupção como fenômeno social e político. Revista de Direito Administrativo. Rio de Janeiro, jul./set. 1991.

FERREIRA FILHO, Manoel Gonçalves. Comentários à Constituição brasileira. São Paulo: Saraiva, 1984.

FERREIRA FILHO, Manoel Gonçalves. Comentários à Constituição brasileira de 1988. São Paulo: Saraiva, 1992. v. 2.

FERREIRA FILHO, Manoel Gonçalves. Curso de direito constitucional. São Paulo: Saraiva, 1999.

FERREIRA FILHO, Manoel Gonçalves. Curso de direito constitucional. São Paulo: Saraiva, 2010.

FERREIRA FILHO, Manoel Gonçalves. Do processo legislativo. São Paulo: Saraiva, 2002.

FERREIRA FILHO, Manoel Gonçalves. Princípios fundamentais de direito constitucional. São Paulo: Saraiva, 2010.

FIGUEIREDO, Lúcia Valle. Curso de direito administrativo. São Paulo: Malheiros, 1998.

FILGUEIRAS, Fernando. Corrupção, democracia e legitimidade. Belo Horizonte: UFMG, 2008.

GAUDEMET, Yves. Droit administratif général. Paris: LGDJ, 2001.

GAUDEMET, Yves. Traité de droit administratif. Paris: LGDJ, 2001.

GORDILLO, Agustín. Tratado de derecho administrativo. Belo Horizonte: Del Rey, 2003. t. I.

HAMON, Francis. TROPER, Michel. BURDEAU, Georges. Direito constitucional. Barueri: Manole, 2005. 
HAMILTON, Alexander; MADISON, James; JAY, John. O federalista, n. 57. Tradução de Heitor de Almeida Herrera. Brasília: Editora da UnB, 1984.

HAURIOU, Maurice. Précis de droit constitutionnel. Paris: Recueil Sirey, 1929.

HELLER, Herman. Teoria do Estado. São Paulo: Mestre Jou, 1968.

HOLANDA, Sérgio Buarque de. Raízes do Brasil. São Paulo: Companhia das Letras, 1995.

JELLINEK, Georg. Teoría general del Estado. Tradução de Fernando de los Rios. México:

Fondo de Cultura Económica, 2004.

JÚNIOR, Dirley da Cunha. Curso de direito constitucional. Bahia: Podium, 2010.

JÚNIOR, Hamilton Rangel. Princípio da moralidade institucional. São Paulo: J. de Oliveira, 2001.

JÚNIOR, José Cretella. Comentários à Constituição brasileira de 1988. São Paulo: Forense Universitária, 1992. v. V.

KELSEN, Hans. Jurisdição constitucional. São Paulo: Martins Fontes, 2007.

KELSEN, Hans. Teoria pura do direito. Tradução de João Baptista Machado. São Paulo: Martins Fontes, 2006.

LOCKE, John. Dois tratados sobre o governo. São Paulo: Martins Fontes, 1998.

LOEWENSTEIN, Karl. Brazil under Vargas. New York: Macmillan Company, 1942.

LOEWENSTEIN, Karl. Teoría de la constitución. Tradução de Alfredo Gallego Anabitarte. Barcelona: Ediciones Ariel, 1957.

LOMBA, Pedro. Teoria da responsabilidade política. Coimbra: Coimbra Editora, 2008.

MANIN, Bernard; PRZEWORSKI, Adam; STOKES, Susan C. Democracy, accoutability and representation. Cambridge: Cambridge University Press, 2003.

MAQUIAVEL, Nicolau. O príncipe. Tradução de Antonio Caruccio-Caporale. Porto Alegre: L\&PM, 2007.

MARX, Karl. A ideologia alemã. São Paulo: Grijalbo, 1977.

MAXIMILIANO, Carlos. Comentários à Constituição brasileira. Rio de Janeiro: Freitas Bastos, 1948. v. II.

MEIRELLES, Hely Lopes. Direito administrativo brasileiro. São Paulo: Malheiros, 2005.

MEIRELLES, Hely Lopes. Direito municipal brasileiro. São Paulo: Malheiros, 2008.

MELLO, Celso Antonio Bandeira de. Curso de direito administrativo. São Paulo: Malheiros, 2008. 
MELLO, Celso Antonio Bandeira de. Discricionariedade e controle jurisdicional. São Paulo: Malheiros, 2003.

MELLO, Oswaldo Aranha Bandeira de. Princípios gerais de direito administrativo. Rio de Janeiro: Forense, 1969. v. II.

MENDES, Antonio Carlos. Introdução à teoria das inelegibilidades. São Paulo: Malheiros, 1994.

MICHELS, Robert. Os partidos políticos. Tradução de Hamilton Trevisan. São Paulo: Senzala, s/d.

MILL, John Stuart. Considerações sobre o governo representativo. Tradução de E. Jacy Monteiro. São Paulo: Ibrasa, 1964.

MILLS, C. Wrigh. A sociedade de massas. In: FORACCHI, Marialice Mencarini, MARTINS, José de Souza (Org.). Sociologia e sociedade: leituras de introdução à sociologia. Rio de Janeiro: Livros Técnicos e Científicos, 1977.

MIRANDA, Jorge. Funções do Estado. Rio de Janeiro: Revista de Direito Administrativo, 1991.

MIRANDA, Jorge. Teoria do Estado e da constituição. Rio de Janeiro: Forense, 2003.

MIRANDA, Pontes de. Comentários à Constituição de 1967, com a Emenda n. 01 de 1969. São Paulo: Revista dos Tribunais, 1970. t. III.

MONTESQUIEU, Charles-Louis de Secondat. O espírito das leis. Tradução de Cristina Murachco. São Paulo: Martins Fontes, 2005.

MORAES, Alexandre de. Constituição do Brasil interpretada e legislação constitucional. São Paulo: Atlas, 2002.

PINTO, Djalma. Direito eleitoral: improbidade administrativa e responsabilidade fiscal. São Paulo: Atlas, 2007.

PORTO, Walter Costa. Dicionário do voto. São Paulo: Giordano, 1995.

PRÉLOT, Marcel. Institutions politiques et droit constitutionnel. Paris: Dalloz, 1963.

QUEIRÓ, Afonso Rodrigues. Estado-polícia, Estado de direito e poder discricionário. Coimbra: Coimbra Editora, 1989. v. I: Estudos de Direito Público.

QUEIRÓ, Afonso Rodrigues. Teoria dos actos de governo. Coimbra: Coimbra Editora, 1989. v. I: Estudos de Direito Público.

RAWLS, Jhon. Uma teoria da justiça. São Paulo: Martins Fontes, 2008. 
REALE, Miguel. Decoro parlamentar e cassação de mandato eletivo. São Paulo: Revista dos Tribunais, 1969.

ROBESPIERRE, Maximilien de. Discursos e relatórios na Convenção. Tradução de Maria Helena Franco Martins. Rio de Janeiro: Contraponto, 1999.

ROCHA, Cármen Lúcia Antunes. Princípios constitucionais da administração pública. Belo Horizonte: Del Rey, 1994.

ROURE, Agenor. A constituinte republicana. Rio de Janeiro: Imprensa Nacional, 1920.

ROUSSEAU, Jean-Jacques. $O$ contrato social: princípios do direito político. São Paulo: Martins Fontes, 2006.

RUA, Maria das Graças. Desafios da administração pública brasileira: governança, autonomia, neutralidade. Brasília: Revista do Serviço Público, ano 48, n. 3, set./dez. 1997.

SARTORI, Giovanni. A política. Brasília: Editora da UnB, 1997.

SARTORI, Giovanni. A teoria da representação no Estado representativo moderno. Tradução de Ernesta Gaetani e Rosa Gaetani. Minas Gerais: Revista Brasileira de Estudos Políticos, 1962.

SARTORI, Giovanni. Ingeniería constitucional comparada. México: Fondo de Cultura Económica, 2005.

SARTORI, Giovanni. Teoria da democracia revisitada. O debate contemporâneo. São Paulo: Ática, 1994.

SARTORI, Giovanni. Teoria democrática. São Paulo: Fondo de Cultura Económica, 1965.

SCHMITT, Carl. La defensa de la constitución. Barcelona: Editorial Labor, 1931.

SCHMITT, Carl. Sobre el parlamentarismo. Madrid: Tecnos, 1990.

SCHMITT, Carl. Teoría de la constitución. Tradução de Francisco Ayala. Madrid: Alianza Universidad, 2009.

SIEYÉS, Emmanuel Joseph. A constituinte burguesa: qu'est-ce que le Tiers État? Tradução de Norma Azeredo. São Paulo: Lumen Juris, 1997.

SILVA, José Afonso da. Comentário contextual à Constituição. São Paulo: Malheiros, 2006. SILVA, José Afonso da. Comentário contextual à Constituição. São Paulo: Malheiros, 2010. SILVA, José Afonso da. Curso de direito constitucional. São Paulo: Malheiros, 2010. SILVA, José Afonso da. Curso de direito constitucional positivo. São Paulo: Malheiros, 2007. 
SILVA, José Afonso da. Poder constituinte e poder popular: estudos sobre a Constituição. São Paulo: Malheiros, 2007.

SILVA, José Afonso da. Processo constitucional de formação das leis. São Paulo: Saraiva, 2003.

SILVA, José Afonso da. Processo constitucional de formação das leis. São Paulo: Malheiros, 2008.

SILVA FILHO, Derly Barreto e. Controle dos atos parlamentares pelo Poder Judiciário. São Paulo: Malheiros, 2003.

SODRÉ, Roberto Costa de Abreu. O parlamento e o Estado moderno. Brasília: IPEAC, 1973. TEIXEIRA, Carla Costa. A honra da política. Rio de Janeiro: Relume Dumará, 1998.

TEIXEIRA, Carla Costa. Ética e política: velhas questões, novos atores. Brasília: Série Antropologia, 2005, p. 03. Disponível em: <http://vsites.unb.br/ics/dan/Serie387empdf. pdf>. Acesso em: 20 jan. 2011.

TEIXEIRA, José Elaeres Marques. A doutrina das questões políticas no Supremo Tribunal Federal. Porto Alegre: Fabris Editor, 2005.

THOMPSON, Dennis F. Ethics in congress: from individual to institutional corruption. Washington: The Brookings Institution, 1995.

THOMPSON, John B. O escândalo político: poder e visibilidade na era da mídia. Petrópolis: Vozes, 2002.

TOCQUEVILLE, Alexis. La democracia en América. México: Fondo de Cultura Económica, 2002.

TORRINHA, Francisco. Dicionário português-latino. Porto: Editorial Domingos Barreira, 1939.

WEBER, Max. Ciência e política: duas vocações. Tradução de Leonidas Hegenberg e Octany Silveira da Mota. São Paulo: Cultrix, 1983.

WEBER, Max. Parlamentarismo e governo numa Alemanha reconstruída. São Paulo: Abril Cultural, 1974. v. XXXVII. (Coleção Os Pensadores).

WEBER, Max. Economia e sociedade. Tradução de Gabriel Cohn. Brasília: Editora da UnB, 2009. v. 1.

ZAGREBELSKY, Gustavo. El derecho dúctil. Ley, derechos, justicia. Madrid: Trotta, 2008. 
ZORRO, Carlos Sanchez. El parlamento. Sus orígenes y su posterior evolución. Bogotá: Universidad Javeriana, Editorial Omnia, 1965. 